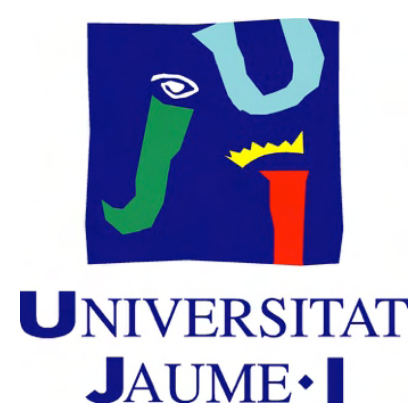

Departament de Química Inorgànica i Orgànica

Programa de Doctorat

Química Molecular i Materials

Còdi 11810

\title{
RECERCA DE NOUS VIDRIATS, FORMULATS A PARTIR DE RESIDUS, I OBTINGUTS PER MITJÀ DE NOVES TECNOLOGIES DE PROCESSAT
} CERÀMIC.

\author{
Tesi Doctoral \\ M. Dolores Notari Abad \\ Directors \\ Dr. Juan B. Carda Castelló \\ Dra. Ester Barrachina Albert \\ Dr. Isaac Nebot Díaz
}





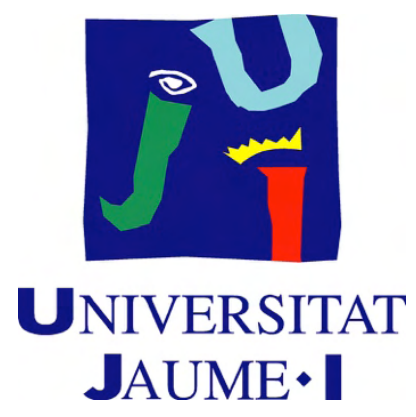

Dr. JUAN B. CARDA CASTELLÓ, Catedràtic de l'àrea de Química Inorgànica de la Universitat Jaume I de Castelló, Dra. ESTER BARRACHINA ALBERT, Investigadora de l'àrea de Química Inorgànica de la Univesitat Jaume I de Castelló i Dr. ISAAC NEBOT DÍAZ, Professor de I'Escola Superior de Ceràmica de l'Alcora.

\section{CERTIFIQUEN:}

Que Na. M. Dolores Notari Abad, Llicenciada en Ciències Químiques per la Universitat Jaume I de Castelló, ha desenvolupat sota la nostra direcció el treball anomenat: "RECERCA DE NOUS VIDRIATS, FORMULATS A PARTIR DE RESIDUS, I OBTINGUTS PER MITJÀ DE NOVES TECNOLOGIES DE PROCESSAT CERÀMIC", al Departament de Química Inorgànica i Orgànica, per assolir el grau de Doctora en Química per la Universitat Jaume I de Castelló.

I perquè conste, als efectes oportuns, signem aquest certificat en la Universitat Jaume I, a 22 de desembre de 2015.
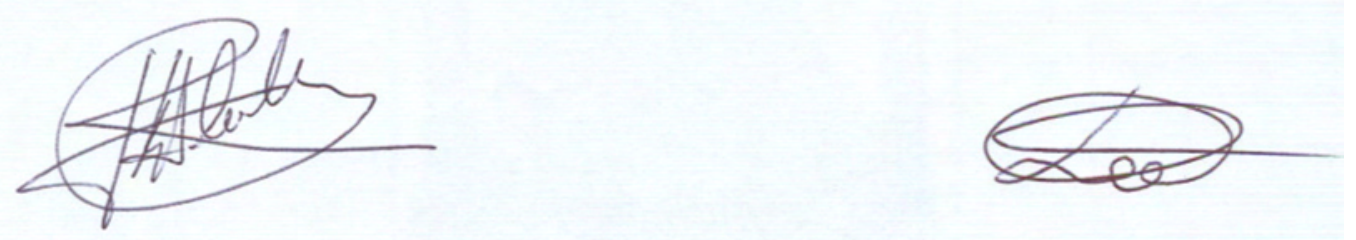

Dr. Juan B. Carda Castelló

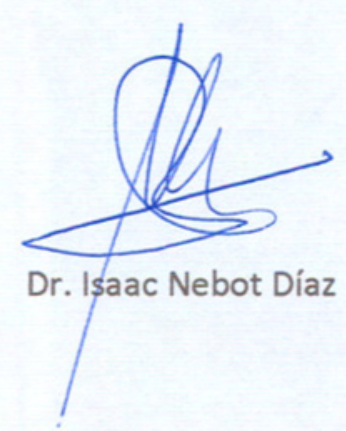

Dra. Ester Barrachina Albert 

A ma mare. A les dones.

A Vicent, Oriol i la resta de la família, per oferir-me un somriure en els moments difícils. 



\section{Agraïments:}

En primer lloc, em sent obligada a agrair als directors de l'ESCAL, Fernando, Manolo i Gertrudis, l'oportunitat d'emprar les instal·lacions del centre per la realització de la tesi, així com a la resta de professorat del centre, on treballe actualment. Vull destacar sincerament el meu agraïment a Jordi, que ha estat el millor company que es puga tindre des que vam començar junts aquest projecte fa gairebé deu anys.

També vull reconèixer el recolzament i l'esforç de tots els membres del grup de treball què, sota la direcció de Juan, han collaborat de diferents maneres en la realització d'aquest treball: Diego, Rafa, Ivan, Aitor i Tedy, així com els que han passat pel departament durant aquests anys, com Javier i Gustavo. També als Tonis, membres de la Càtedra d'Innovació Ceràmica de Vila-real i a Fernando. Ha estat un plaer treballar amb vosaltres.

Com no podria ser d'una altra manera, recordaré amb estima els ànims i la dedicació a la feina que demostren els membres del SCIC a la seva tasca diària. Lourdes, Maruixa i Jose Miguel, sempre esteu amanits per regalar una paraula amable. Especialment, vull destacar les classes magistrals de microscòpia de Javi, sense tu no haguera segut igual, i les idees aportades, sempre constructives, fins i tot divendres al vespre, per Gabriel.

Són moltes les empreses què, al cap dels anys, han col-laborat aportant materials o suport tècnic per aquest estudi. Com a mostra, vull expressar el meu agraïment més sincer a Sigfrido, de Camacho Recicling, pels vidres i el suport tècnic, a Colores Ceràmicos per el suport i a Colorobbia pels assajos d'ICP-OES.

També al professorat del departament de ceràmica de l'IES Serra d'Espadà, en Onda, que han segut tant gentils de permetre'm d'utilitzar la seva lupa, i als de l'IES Caminàs, per oferir-la. Sempre és grat tornar a treballar junts.

Un abraçada i reconeixement destacat per a $\mathrm{M}^{\mathrm{a}}$ Carmen, que va realitzar els assajos bactericides a les instal-lacions de l'IES Vicent Castell, de Castelló, i que ha estat a les bones i a les no tant bones des que vam començar a estudiar plegades fa molts i molts anys.

No puc oblidar-me tampoc dels companys de Saragossa, Ruth i Carlos, que han recolzat tota la secció del tractament tèrmic del forn i l'aplicació làser. El vostre assessorament ha estat imprescindible per a realitzar l'estudi que presente a continuació.

Finalment, vull fer un reconeixement per la feina feta als directors de tesis, el Dr. Juan Carda, per facilitar-me la tasca a tots els nivells i animar-me sempre a continuar, la Dra. Ester Barrachina, que s'ha lliurat en cos i ànima durant tot aquest temps, malgrat d'haver de menjar per a tres, i el Dr. Isaac Nebot, amb qui he compartit moltes experiències a l'escola durant aquests anys. Sense la vostra ajuda i paciència no haguera arribat fins ací. 
A tota la meva família, que ha sabut entendre que a voltes no estava per ells, sinó que havia de dedicar-me unes horetes a fer una tasca que no, no formava part de la meva feina, però que calia acabar. Intentaré compensar-vos-hi, de veres.

A tots els que han col-laborat, físicament $\mathrm{i}$ anímica, perquè aquest projecte haja tirat en davant. Si m'he deixat algun nom, per favor, disculpeu-me. Gràcies per la influència positiva. 
Índex.

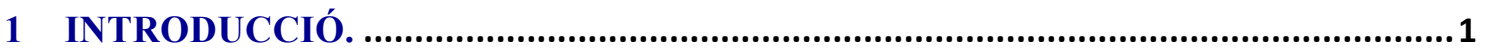

1.1 LA TECNOLOGIA CONVENCIONAL DE FABRICACIÓ D'ESMALTS. ................................... 2

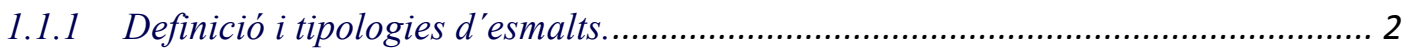

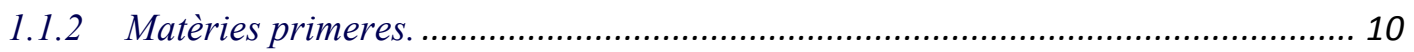

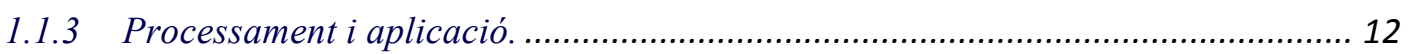

1.2 TECNOLOGIES EMERGENTS EN LA FABRICACIÓ D'ESMALTS O DE SÒLIDS INORGÀNICS, OBTINGUDES PER OPTIMITZAR EL PROCÉS INDUSTRIAL A NIVELL ECONÒMIC I MEDIAMBIENTAL I MILLORAR LES PROPIETATS DELS PRODUCTES. .......................................... 18

1.2.1 Aplicacions del LÀSER en la indústria ceràmica. ............................................... 21

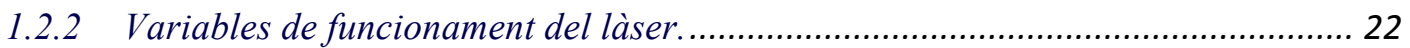

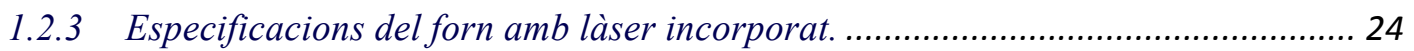

1.3 VALORITZACIÓ DE RESIDUS INDUSTRIALS I REPERCUSSIÓ MEDIAMBIENTAL.................. 26

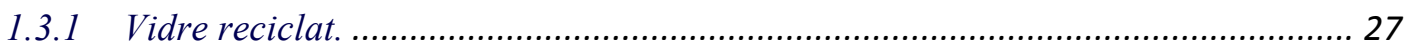

1.3.2 Cendres $i$ escòria de centrals tèrmiques. ............................................................. 28

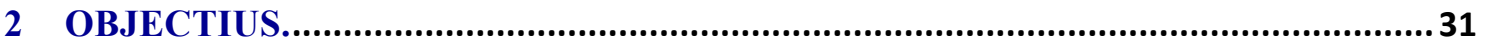

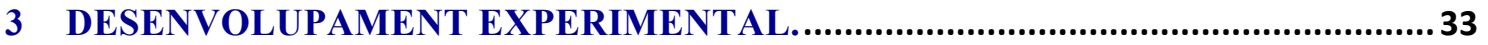

3.1 ESTUDI DELS RESIDUS UTILITZATS COM A MATĖRIES PRIMERES.................................... 37

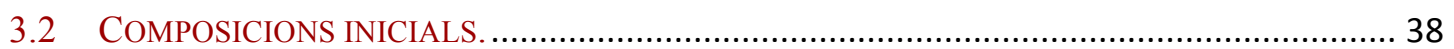

3.3 PREPARACIÓ I CARACTERITZACIÓ DE LES COMPOSICIONS. .......................................... 40

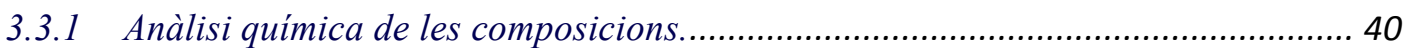

3.3.2 Caracterització de les composicions amb Anàlisis tèrmiques diferencial $i$

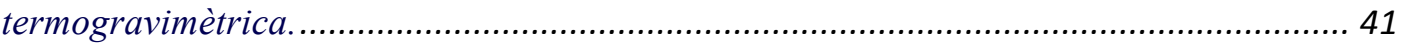

3.3.3 Caracterització mineralògica mitjançant difracció de raig $X$ de la frita molturada. 41

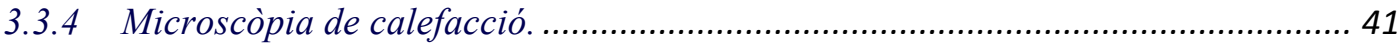

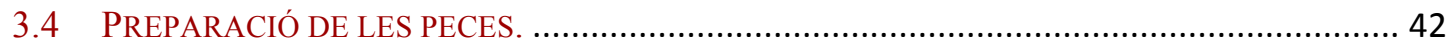

3.5 CARACTERITZACIÓ INICIAL DELS VIDRIATS OBTINGUTS.................................................. 45

3.5.1 Caracterització mineralògica amb Difracció de Raigs $X$.................................... 45

3.5.2 Caracterització per microscòpia de Rastreig Electrònic..................................... 45

3.6 ESTUDI DE LES VARIABLES DE COCCIÓ AMB EL FORN MONOSTRAT AMB LÀSER

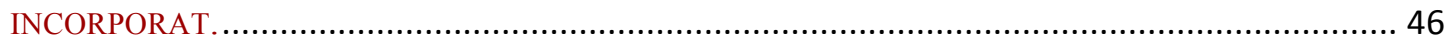

3.7 ESTUDI DELS VIDRIATS OBTINGUTS AMB EL FORN MONOSTRAT AMB LÀSER................. 48

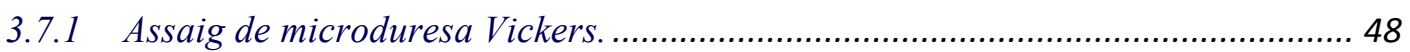

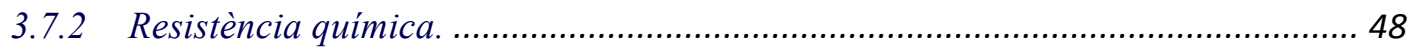

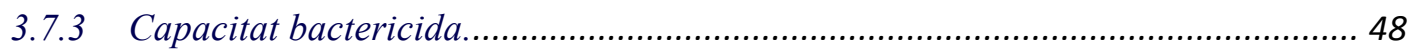

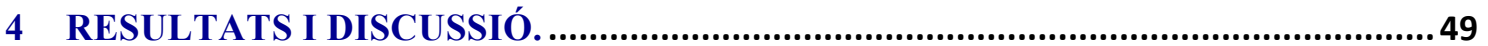

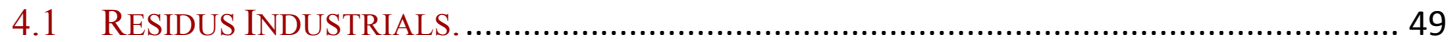

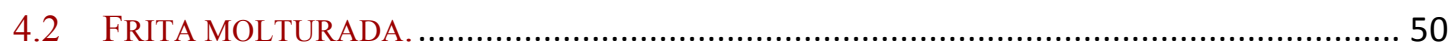

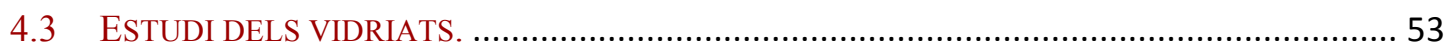

4.3.1 Selecció de les composicions. Anàlisis mineralògiques de Difracció de Raigs X. . 53

4.3.2 Caracterització de les composicions seleccionades........................................... 58 
4.4 COMPARATIVA ENTRE LES PECES DE COMPOSICIONS FRITADES I NO FRITADES EN FORN MUFLA DE LABORATORI.

4.4.1 Composició A1........................................................................................... 96

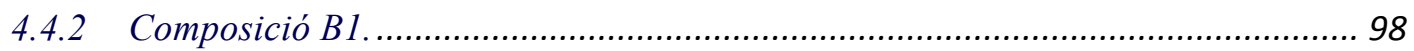

4.4.3 Composició E1.................................................................................. 100

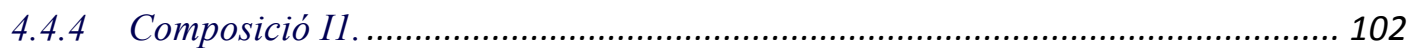

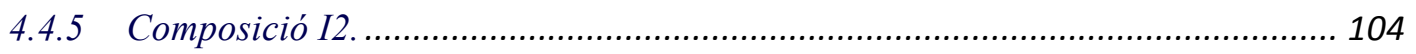

4.4.6 Composició J1....................................................................................... 106

4.4.7 Composició J3......................................................................... 108

4.5 ESTUDI DE LA COCCIÓ FINAL DE LES COMPOSICIONS SELECCIONADES EN FORN MONOSTRAT ELÈCTRIC AMB LÀSER INCORPORAT. ..................................................... 110

4.5.1 Composició A1................................................................................... 110

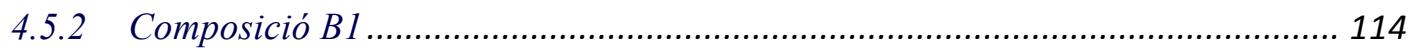

4.5.3 Composició E1............................................................................ 116

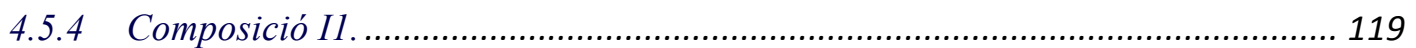

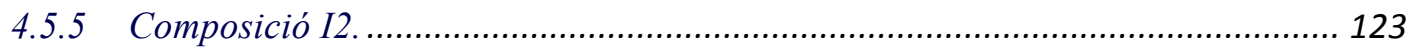

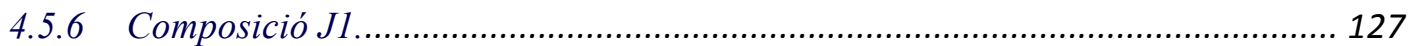

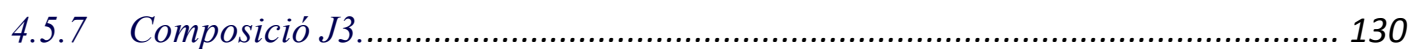

4.5.8 Estudi dels vidriats acolorits $i$ serigrafiats. .............................................. 132

4.5.9 Estudi de les propietats dels vidriats. ....................................................... 134

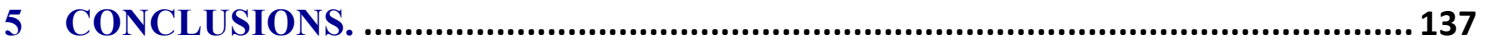

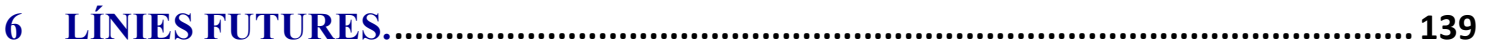

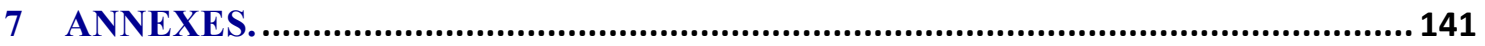

7.1 DIFRACTOMETRIA LÀSER DE LES SUSPENSIONS. ................................................. 141

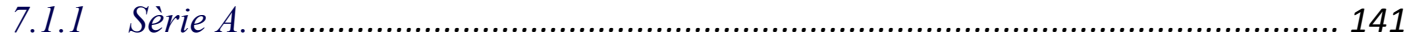

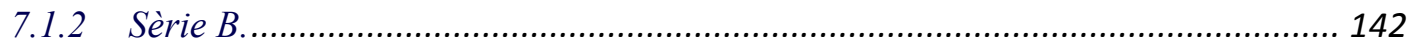

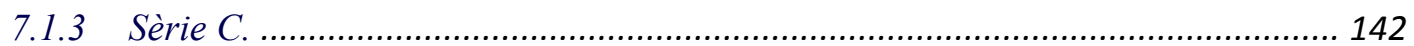

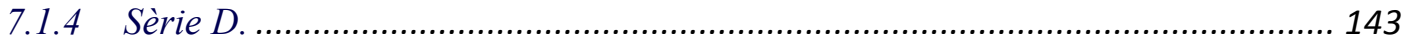

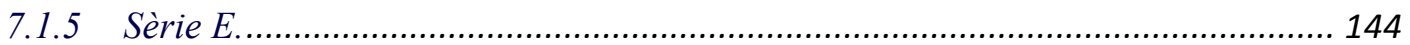

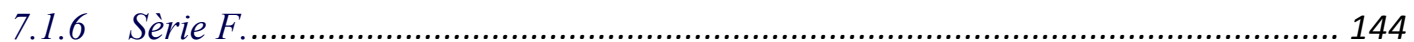

7.1.7 Sèrie $G$......................................................................................... 145

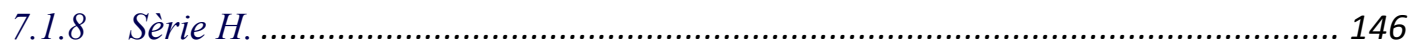

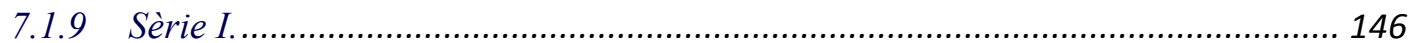

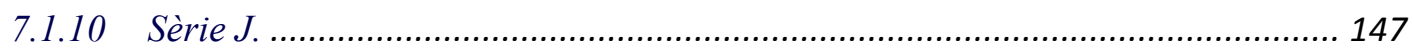

7.2 ANÀLISIS TÈRMIQUES DE LES COMPOSICIONS NO SELECCIONADES. ......................... 148

7.3 DIFRACCIÓ DE RAIGS X DE LES FRITES. .......................................................... 150

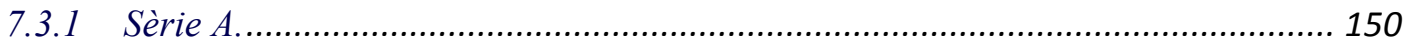

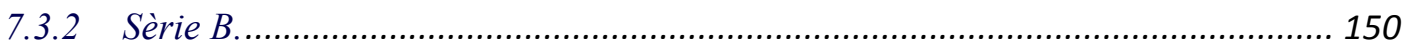

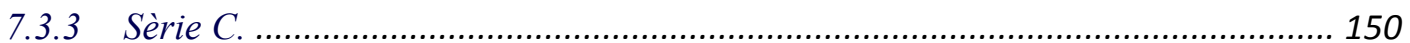

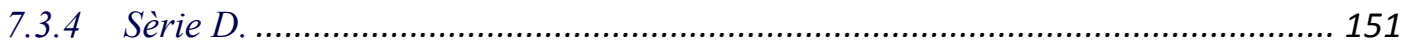

7.3.5 Sèrie E

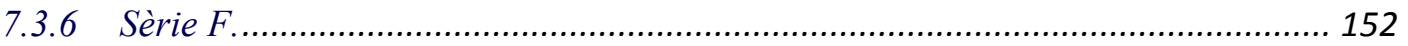

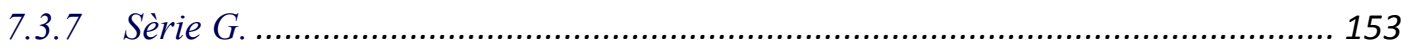

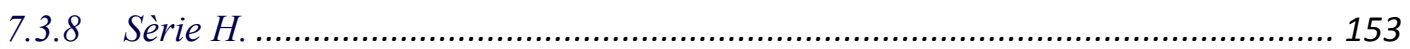




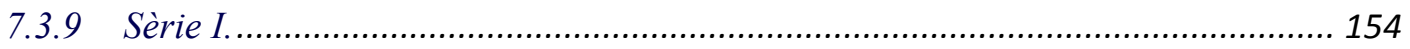

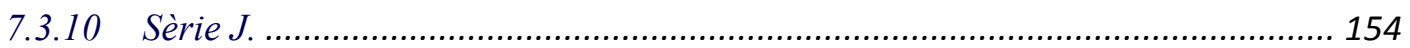

7.4 DIFRACCIÓ DE RAIGS X DE LES COMPOSICIONS NO SELECCIONADES. .......................... 155

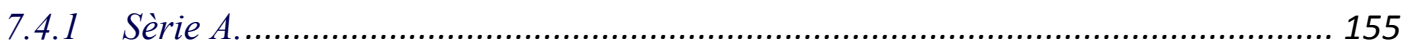

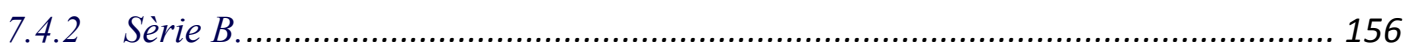

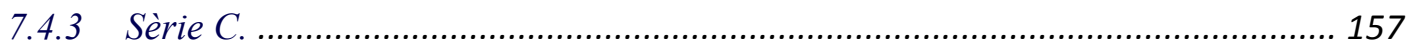

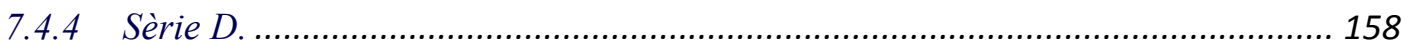

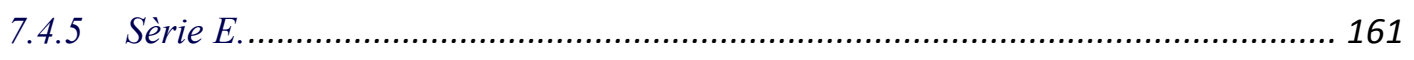

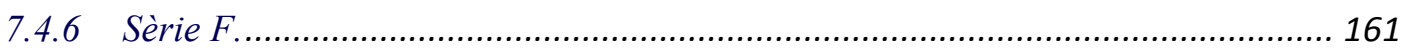

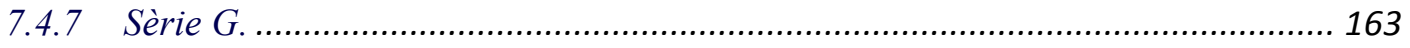

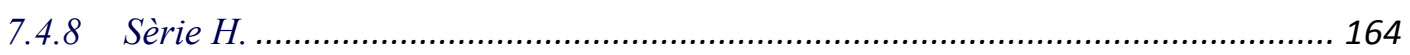

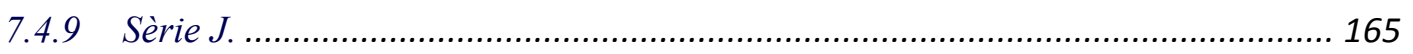

7.5 DiAgrames DE GINSBERG, RASCHIN-TSCHETVERITKOV I LEBEDEVA DE TOTES LES

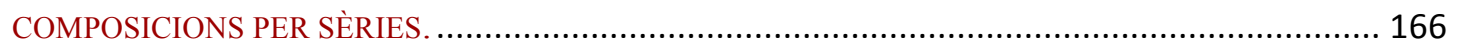

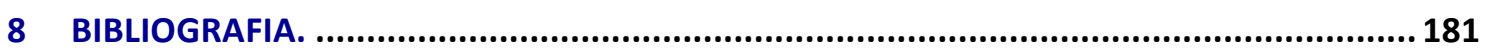





\section{Referències.}

- AQ: Anàlisi química.

- ATD/TG: Anàlisis termodiferencial i gravimètrica.

- CW: Sigles d'ona contínua en anglès.

- DRX: Difracció de Raigs X.

- EDX: Sigles de microanàlisi per dispersió d'energies de raigs X.

- EPD: Sigles de deposició electroforètica en anglès.

- FRX: Fluorescència de Raigs X.

- $\gamma:$ Tensió superficial.

- ICP-OES: Sigles d'espectrometria de masses per plasma d'acoblament inductiu amb especiació isotòpica, en angles.

- kHz: kilohertzs.

- LED: Sigles de diode emissor de llum en anglès.

- LM: Sigles de mecanitzat làser en anglès.

- MEMS: Sigles dels sistemes electromecànics en anglès.

- $\eta$ : Viscositat.

- PM: Sigles d'intensitat de sortida de làser polsada, en anglès. Pot arribar a ser de femptosegons i molt energètiques.

- PPC: Pèrdues per calcinació.

- RO: Òxids alcalins, amb funció bàsica segons la classificació de Seger. R és un metall i $\mathbf{O}$ és l'oxigen.

- $\mathbf{R}_{2} \mathbf{O}_{3}$ : Òxids amfòters segons la classificació de Seger, on $\mathbf{R}$ és un metall i $\mathbf{O}$ és l'oxigen.

- R.Q.: Resistència química.

- SEM: Sigles de Microscopi electrònic de rastreig en anglès.

- TTT: Transformació-Temperatura-Temps.

- Vickers: Assaig de microduresa Vickers. 



\section{Índex de taules.}

Taula 1 Codificació de les matèries primeres utilitzades. ......................................................... 37

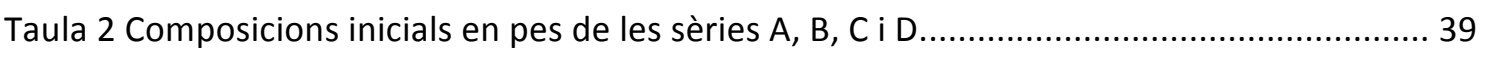

Taula 3 Composicions inicials en pes de les sèries E, F, G, H, I i J........................................... 39

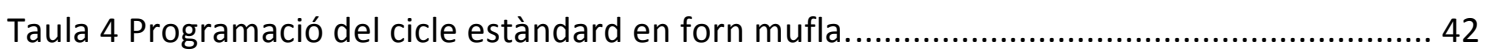

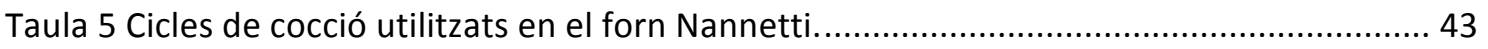

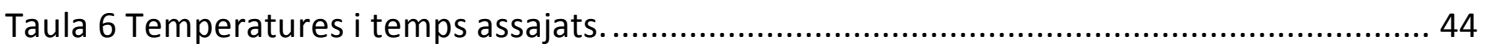

Taula 7 Anàlisis químiques en pes dels residus utilitzats. ......................................................... 49

Taula 8 Anàlisis químiques de les frites en pols de les composicions inicials. .......................... 51

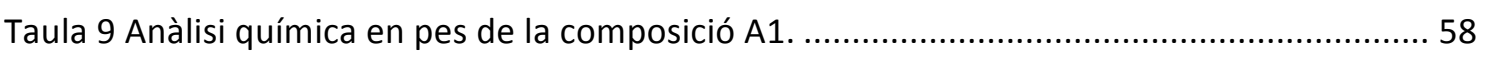

Taula 10 Temperatures característiques de la composició A1, mesurades amb microscopi de

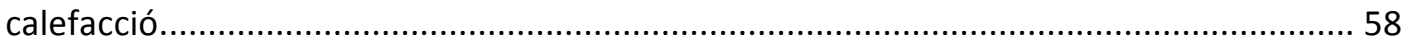

Taula 11 Microanàlisis per dispersió d'energies de raigs $X$ de la secció de la composició $A 1$ amb 1 h de manteniment a $1000 \circ \mathrm{C}$ 60

Taula 12 Microanàlisis per dispersió d'energies de raigs $X$ de la secció de la composició A1 a cicle de cocció estàndard.

Taula 13 Composició mineralògica dels botons de fusió de la composició A1.

Taula 14 Anàlisi química en pes de la composició B1.

Taula 15 Temperatures característiques de la composició B1, mesurades amb microscopi de calefacció.

Taula 16 Microanàlisis per dispersió d'energies de raigs $X$ de la superfície de la composició B1 amb $1 \mathrm{~h}$ de manteniment a 1000 으.

Taula 17 Microanàlisi per dispersió d'energies de raigs $X$ de la secció de la composició B1 a cicle de cocció estàndard.

Taula 18 Composició mineralògica dels botons de fusió de la composició B1.

Taula 19 Anàlisi química en pes de la composició E1.

Taula 20 Temperatures característiques de la composició E1, mesurades amb microscopi de calefacció.

Taula 21 Microanàlisis per dispersió d'energies de raigs $X$ de la secció de la composició $E 1$ amb $1 \mathrm{~h}$ de manteniment a $1200^{\circ} \mathrm{C}$. 
Taula 22 Microanàlisis per dispersió d'energies de raigs $\mathrm{X}$ de la composició $\mathrm{E} 1$ a cicle de cocció estàndard.

Taula 23 Composició mineralògica dels botons de fusió a la frita E1. 74

Taula 24 Anàlisis químiques en pes de les composicions I1 i 12 . 75

Taula 25 Temperatures característiques de les composicions I1 i I2, mesurades amb microscopi de calefacció.

Taula 26 Microanàlisis per dispersió d'energies de raigs $X$ de la composició 11 amb 1 hora de manteniment a 1000 ㅇ $\mathrm{C}$

Taula 27 Microanàlisis per dispersió d'energies de raigs $X$ de la superfície de la composició 12 amb $1 \mathrm{~h}$ de manteniment a $1000^{\circ} \mathrm{C}$.

Taula 28 Microanàlisis per dispersió d'energies de raigs $X$ de la secció de la composició 11 a cicle estàndard.

Taula 29 Microanàlisis per dispersió d'energies de raigs $X$ de la composició 12 a cicle estàndard.

Taula 30 Composició mineralògica dels botons de fusió de la composició I1. 83

Taula 31 Composició mineralògica dels botons de fusió de la composició 12 . 83

Taula 32 Anàlisi química en pes de la composició J1.

Taula 33 Temperatures característiques de la composició J1, mesurades amb microscopi de calefacció. 84

Taula 34 Microanàlisis per dispersió d'energies de raigs $X$ de la secció de la composició $J 1$ amb 1 hora de manteniment a $900 \circ \mathrm{C}$. 86

Taula 35 Microanàlisis per dispersió d'energies de raigs $X$ de la secció i la superfície de la composició J1 a cicle de cocció estàndard.

Taula 36 Composició mineralògica dels botons de fusió de la composició J1.

Taula 37 Anàlisi química en pes de la composició J3. 90

Taula 38 Temperatures característiques de la composició J3 mesurades amb microscopi de calefacció.

Taula 39 Microanàlisis per dispersió d'energies de raigs $X$ de la fase vítria i cristal-lina de la composició J3 amb 1 h de manteniment a 900ㄷ.

Taula 40 Microanàlisis per dispersió d'energies de raigs $X$ de la composició J3 a cicle de cocció estàndard. 
Taula 42 Anàlisis químiques de la composició A1 crua (A1C) i fritada (A1). ............................. 96

Taula 43 Anàlisis químiques de la composició B1 crua (B1C) i fritada (B1) .............................. 98

Taula 44 Anàlisis químiques de la composició E1 crua (E1C) i fritada (E1) ............................... 100

Taula 45 Anàlisis químiques de les composicions I1 i I1C. ......................................................... 102

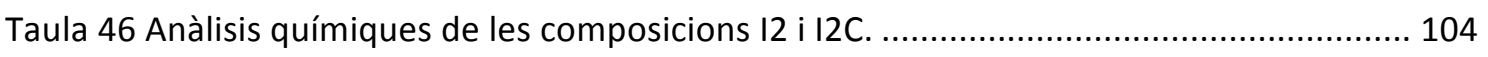

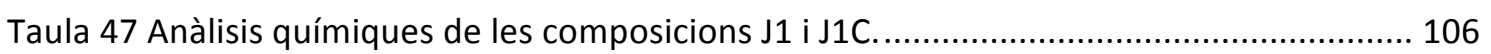

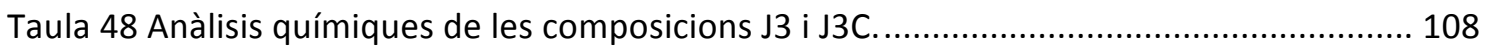

Taula 49 Microanàlisis per dispersió d'energies de raigs $X$ de la superfície de les peces $A 1, A 1 C i$

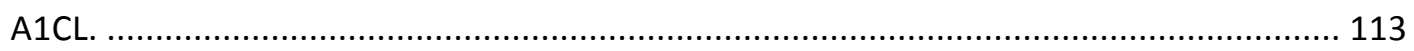

Taula 50 Microanàlisis per dispersió d'energies de raigs $X$ de la superfície de les peces E1, E1C $i$

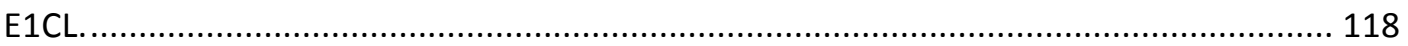

Taula 51 Microanàlisis per dispersió d'energies de raigs $X$ de les peces de composició $11,11 \mathrm{C}$ i

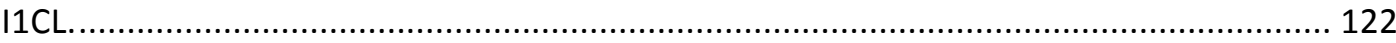

Taula 51 Microanàlisis per dispersió d'energies de raigs $X$ de les peces de composició $I 1 C L$ i

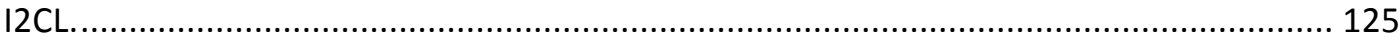

Taula 53 Resultats dels assajos de microduresa Vickers, part 1......................................... 134

Taula 54 Resultats dels assajos de microduresa Vickers, part 2. ......................................... 134

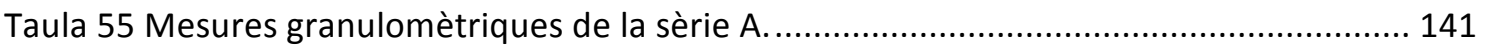

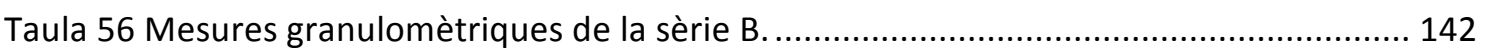

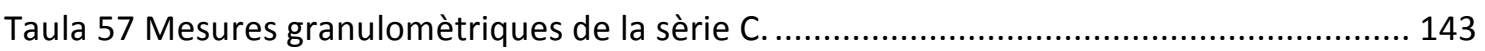

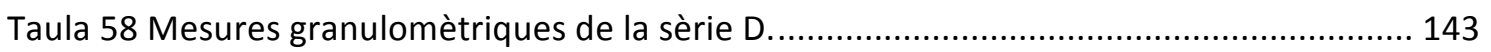

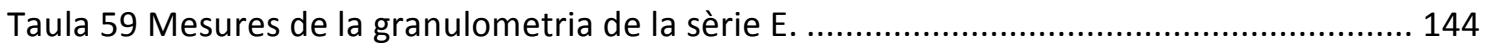

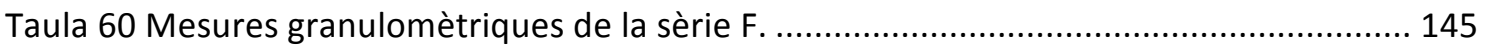

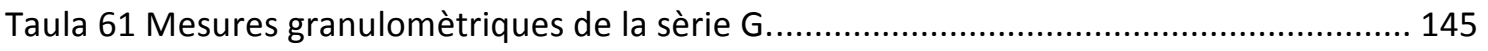

Taula 62 Mesures granulomètriques de la sèrie H.............................................................. 146

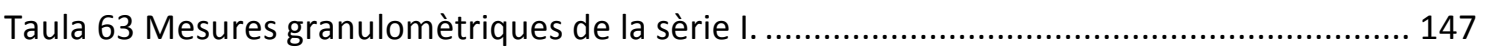

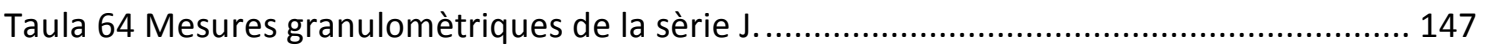





\section{Índex de figures.}

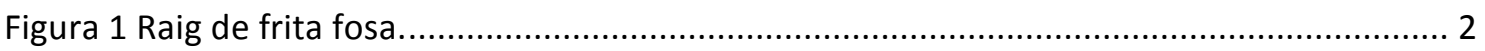

Figura 2 Peu de llum decorat amb pasta egípcia. .......................................................... 3

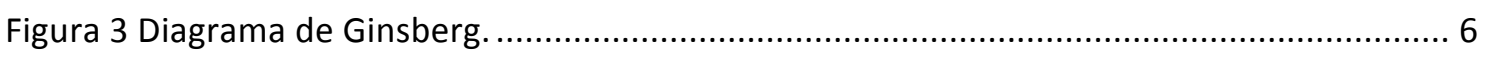

Figura 4 Diagrama de Raschin-Tschetveritkov. ............................................................. 7

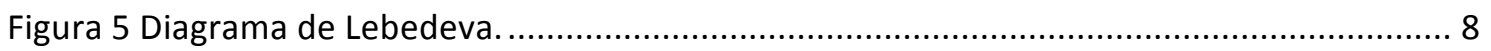

Figura 6 Peça amb brillantor metàl·lica............................................................. 10

Figura 7 Distribució de material des de sitges fins la mescladora.................................... 13

Figura 8 Esquema de fabricació de frites. ........................................................... 14

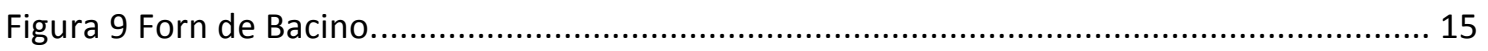

Figura 10 Forn industrial de fabricació de frites. .................................................... 15

Figura 11 Refredament de la frita amb aigua............................................................ 16

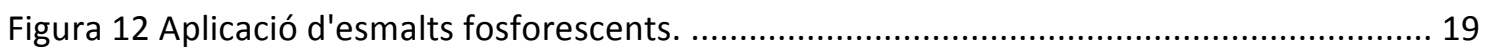

Figura 13 Forn monostrat amb làser incorporat a la zona de cocció................................. 21

Figura 14 Forn monostrat de dimensions industrials amb làser incorporat a la zona de cocció.

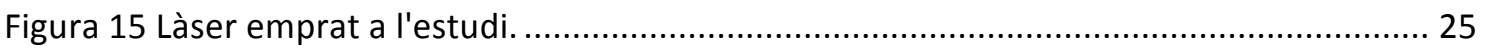

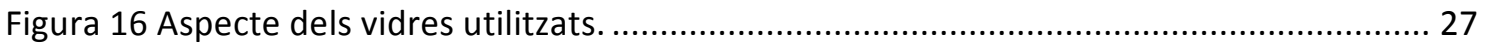

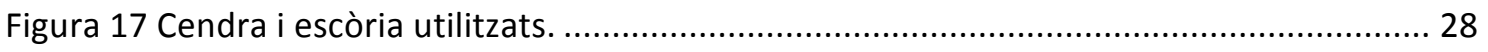

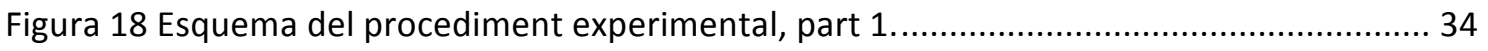

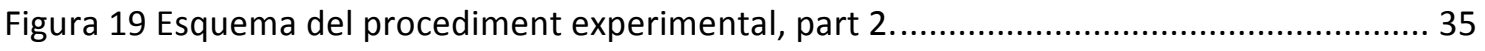

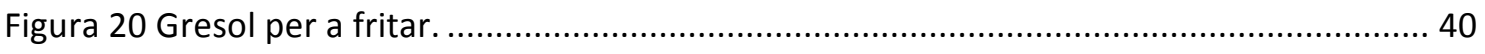

Figura 21 Peça esmaltada amb patí de 0,7mm d'espessor. .............................................. 42

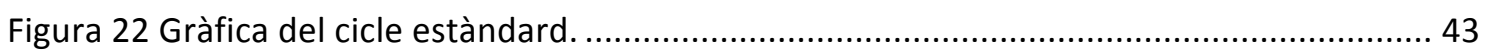

Figura 23 Cicle de cocció amb manteniment de 30 minuts a 1100 ㄷ................................ 44

Figura 24 Cicle de cocció del forn monostrat amb làser. .............................................. 46

Figura 25 Forn monostrat de proves amb obertura per a làser..................................... 47 
Figura 26 Difractometria de la composició A1 amb 1h de manteniment a 900, 1000 i 1200ㄷ. 53

Figura 27 Difractometria de la composició B1 amb 1h de manteniment a 900, 1000 i 1200ㄷ. 54

Figura 28 Difractometria de la composició E1 a 1h de manteniment a 900, 1000 i 1200ㄷ...... 54

Figura 29 Difractometria de la composició I1 amb 1h de manteniment a 900, 1000 i 1200C. 55

Figura 30 Difractometria de la composició 12 a 1h de manteniment a 900, 1000 i 1200 …..... 55

Figura 31 Difractometria de la composició J1 a 1h de manteniment a 900, 1000 i 1200C. ..... 56

Figura 32 Difractometria de la composició J3 a 1h de manteniment a 900, 1000 i 1200 ㄷ. ..... 56

Figura 33 Anàlisis Tèrmiques Diferencial i Termogravimètrica de la composició A1. 59

Figura 34 Micrografia de la secció de la composició A1, amb una hora de manteniment a $1000 \circ \mathrm{C}$.

Figura 35 Micrografia de la superfície de la composició $A 1$, amb una hora de manteniment a $1000 \circ \mathrm{C}$.

Figura 36 Micrografia de la secció de la composició A1 a cicle de cocció estàndard. 60

Figura 37 Micrografia de la superfície de la composició A1 al cicle de cocció estàndard. 61

Figura 38 Difractograma de la superfície de la composició $\mathrm{A} 1 \mathrm{amb}$ 1h a $1000^{\circ} \mathrm{C}$ i a cicle de cocció estàndard.

Figura 39 Diagrama Transformació-Temperatura-Temps de la fase hematites en la superfície de la composició A1.

Figura 40 Diagrama Transformació-Temperatura-Temps de la fase albita en la superfície de la composició A1.

Figura 41 Anàlisis Tèrmiques Diferencial i Termogravimètrica de la composició B1.

Figura 42 Micrografia de la secció de la composició B1 amb una hora de manteniment a $1000 \circ \mathrm{C}$.

Figura 43 Micrografia de la superfície de la composició B1 amb una hora de manteniment a $1000 \circ \mathrm{C}$.

Figura 44 Micrografia de la secció de la composició B1 a cicle de cocció estàndard. 66

Figura 45 Micrografia de la superfície de la composició B1 a cicle de cocció estàndard. 67

Figura 46 Difractograma de la superfície de la composició B1 amb 1h a 1000ㄷ i a cicle de cocció estàndard.

Figura 47 Diagrama Transformació-Temperatura-Temps de la fase borat de sodi a la superfície de la composició B1. 
Figura 48 Anàlisis tèrmiques diferencial i termogravimètrica de la composició E1.

Figura 49 Micrografia de la secció (E1) i de la superfície (E1s) de la composició E1 amb una hora de manteniment a $1200^{\circ} \mathrm{C}$.

Figura 50 Micrografia de la secció de la composició E1 a cicle de cocció estàndard. 72

Figura 51 Micrografia de la superfície de la composició E1 a cicle de cocció estàndard.

Figura 52 Difractograma de la superfície de la composició E1 amb 1h a 1200ㄷ i a cicle de cocció estàndard.

Figura 53 Diagrama Transformació-Temperatura-Temps de la fase silicat de ferro a la superfície de la composició E1.

Figura 54 Anàlisis tèrmiques diferencial i termogravimètrica de la composició I1. 76

Figura 55 Anàlisis tèrmiques diferencial i termogravimètrica de la composició 12 . 76

Figura 56 Micrografies de la secció (I1) i de la superfície (I1s) de la composició I1 amb una hora de manteniment a 1000 ․ .

Figura 57 Micrografia de la secció de la composició 12 amb una hora de manteniment a $1000 \circ \mathrm{C}$.

Figura 58 Micrografia de la superfície de la composició 12 amb una hora de manteniment a $1000 \circ \mathrm{C}$.

Figura 59 Micrografia de la secció de la composició I1 a cicle de cocció estàndard. 79

Figura 60 Micrografia de la superfície de la composició l1 a cicle de cocció estàndard. 79

Figura 61 Micrografia de la secció de la composició 12 a cicle de cocció estàndard. 80

Figura 62 Micrografia de la superfície de la composició 12 a cicle de cocció estàndard. 80

Figura 63 Difractograma de la superfície de la composició 11 amb 1 h a $1000^{\circ} \mathrm{C}$ i a cicle de cocció estàndard.

Figura 64 Difractograma de la superfície de la composició $\mathrm{I} 2 \mathrm{amb} 1 \mathrm{~h}$ a 1000 $\mathrm{C}$ i a cicle de cocció estàndard.

Figura 65 Diagrama Transformació-Temperatura-Temps de la fase augita a la superfície de la composició 11.

Figura 66 Diagrama Transformació-Temperatura-Temps de la fase augita a la superfície de la composició 12 .

Figura 67 Anàlisis tèrmiques diferencial i termogravimètrica de la composició J1. 85

Figura 68 Micrografia de la secció de la composició J1 amb una hora de manteniment a 900ㄷ․ 
Figura 69 Micrografia de la superfície de la composició J1 amb una hora de manteniment a $900 \circ \mathrm{C}$.

Figura 70 Micrografia de la secció de la composició J1 a cicle de cocció estàndard. 86

Figura 71 Micrografia de la superfície de la composició J1 a cicle de cocció estàndard. 86

Figura 72 Difractograma de la superfície de la composició J1 amb 1h a 900ㄷ i a cicle de cocció estàndard.

Figura 73 Diagrama Transformació-Temperatura-Temps de la fase scheelita a la superfície de la composició J1.

Figura 74 Diagrama Transformació-Temperatura-Temps de la fase hidrotungstita a la superfície de la composició J1.

Figura 75 Anàlisis tèrmiques diferencial i termogravimètrica de la composició J3. 91

Figura 76 Micrografia de la secció de la composició J3 amb una hora de manteniment a 900ㄷ.

Figura 77 Micrografia de la superfície de la composició J3 amb una hora de manteniment a $900 \circ \mathrm{C}$.

Figura 78 Micrografia de la secció de la composició J3 a cicle de cocció estàndard.

Figura 79 Micrografia de la superfície de la composició J3 a cicle de cocció estàndard.

Figura 80 Difractograma de la superfície de la composició J3 amb 1h a 900ㄷ C a cicle de cocció estàndard.

Figura 81 Diagrama Transformació-Temperatura-Temps de la fase cerianita a la superfície de la composició J3. 94

Figura 82 Micrografies de la secció les composicions A1 i A1C a cicle estàndard. 96

Figura 83 Micrografies de la superfície de les composicions A1 i A1C.

Figura 84 Difractograma de la superfície de les composicions A1 i A1C a cicle de cocció estàndard.

Figura 85 Micrografies de la secció de la composició B1 crua (B1C) i fritada (B1)..................... 98

Figura 86 Micrografies de la superfície de les composicions B1 i B1C. 98

Figura 87 Difractograma de la superfície de les composicions B1 i B1C a cicle de cocció estàndard.

Figura 88 Micrografies de la secció de les composicions E1 i E1C. 100

Figura 89 Micrografies de la superfície de les composicions E1 i E1C. 100 
Figura 90 Difractograma de la superfície de les composicions E1 i E1C a cicle de cocció estàndard.

Figura 91 Micrografies de la secció de les composicions I1 i I1C. 102

Figura 92 Micrografies de la superfície de les composicions I1 i I1C. 102

Figura 93 Difractograma de la superfície de les composicions I1 i I1C a cicle de cocció estàndard. 103

Figura 94 Micrografies de la secció de les composicions 12 i I2C. 104

Figura 95 Micrografies de la superfície de les composicions 12 i I2C. 104

Figura 96 Difractograma de la superfície de les composicions I2 i I2C a cicle de cocció estàndard. 105

Figura 97 Micrografies de la secció de les composicions J1 i J1C. 106

Figura 98 Micrografies de la superfície de les composicions J1 i J1C. 106

Figura 99 Difractograma de la superfície de les composicions J1 i J1C a cicle de cocció estàndard. 107

Figura 100 Micrografies de la secció de les composicions J3 i J3C. 108

Figura 101 Micrografies de la superfície de les composicions J3 i J3C. 108

Figura 102 Micrografies de la superfície ampliada de les composicions J3 i J3C. 109

Figura 103 Difractograma de la superfície de les composicions J3 i J3C a cicle de cocció estàndard.

Figura 104 Peces de les composicions A1, A1C i A1CL cuites al forn monostrat..... 110

Figura 105 Difractograma de la composició A1 al forn monostrat.

Figura 106 Micrografies de la composició A1 fritada, cuita en forn monostrat, a la secció (A1) i a la superfície (A1s).

Figura 107 Micrografíes de la composició A1 crua a la secció (A1C) i a la superfície (A1Cs), cuites en un forn monostrat.

Figura 108 Micrografies de la secció (A1CL) i la superfície (A1CLs) de la composició A1 crua amb aplicació de radiació làser.

Figura 109 Peces de les composicions B1, B1C i B1CL cuites al forn monostrat.

Figura 110 Difractograma de la composició B1 al forn monostrat.

Figura 111 Micrografies de la secció (B1CL) i la superfície (B1CLs) de la composició B1 cruga amb aplicació de radiació láser. 
Figura 112 Peces de les composicions E1, E1C i E1CL cuites al forn monostrat.

Figura 113 Difractograma de la composició E1 al forn monostrat.

Figura 114 Micrografies de la secció (E1CL) i la superfície (E1CLs) de la composició E1 cruga amb aplicació de radiació làser.

Figura 115 Peces de les composicions I1, I1C i I1CL cuites al forn monostrat. 119

Figura 116 Difractometria de la composició I1 al forn monostrat.

Figura 117 Micrografíes de la composició I1 fritada al forn monostrat, a la secció (I1) i la superfície (I1s).

Figura 118 Micrografíes de la composició I1 crua al forn monostrat, a la secció (I1C) i la superfície (I1Cs).......

Figura 119 Micrografíes de la secció de la composició I1 tractada amb radiació làser a la superfície d'un esmalt sense fritar.

Figura 120 Micrografía de la superfície de la composició I1 tractada amb radiació làser sobre un esmalt sense fritar.

Figura 121 Difractograma d'incidència de la composició I1CL.

Figura 122 Peces de les composicions 12, 12C i I2CL cuites al forn monostrat. 123

Figura 123 Difractograma de la composició 12 al forn monostrat. 124

Figura 124 Micrografies de la secció (I2CL) i la superfície (I2CLs) d'un vidriat I2C al que s'ha aplicat radiació làser.

Figura 125 Micrografia de la secció d'un vidriat de la composició I2 al que s’ha aplicat radiació làser.

Figura 126 Difractograma d'incidència de la composició I1CL.

Figura 127 Peces de les composicions J1, J1C i J1CL cuites al forn monostrat.

Figura 128 Difractograma de la composició J1 al forn monostrat.

Figura 129 Micrografíes de la composició J1 on s’observa el creixement de la hidrotungstita.

Figura 130 Difractograma de la secció (J1C) i la superfície (J1Cs) d'una peça de composició J1C a la que se li ha aplicat radiació làser.

Figura 131 Difractograma de la secció (J1CL) i la superfície (J1CLs) d'una peça de composició J1C a la que se li ha aplicat radiació làser. 129

Figura 132 Peces de les composicions J3, J3C i J3CL cuites al forn monostrat. 130 
Figura 133 Difractograma de la composició J3 al forn monostrat.

Figura 134 Micrografies de la secció (J3CL) i la superfície (J3CLs) d'una peça de composició J3 a la que s'ha aplicat radiació làser.

Figura 135 Peces de les composicions J3V i J3CV cuites al forn monostrat.

Figura 136 Micrografíes de la superficie de les composicions J3 acolorida (J3Vs) i la J3C acolorida (J3CVs).

Figura 137 Micrografíes de la composició J3C acolorida i amb aplicació làser a la secció (J3CVL) i

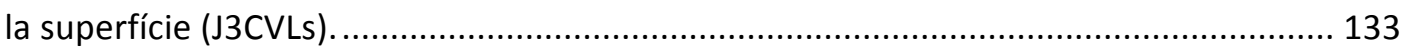

Figura 138 Superfície de la composició I1C serigrafiada i amb el làser aplicat. ........................ 133

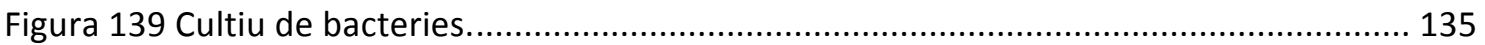

Figura 140 Diagrama diferencial de la granulometria de la sèrie A. ...................................... 141

Figura 141 Diagrama diferencial granulomètric de la sèrie B. .......................................... 142

Figura 142 Diagrama diferencial de la granulometria de la serie C. ...................................... 142

Figura 143 Diagrama diferencial de la granulometría de la sèrie D.................................... 143

Figura 144 Diagrama diferencial de la granulometria de la sèrie E........................................ 144

Figura 145 Diagrama diferencial de la granulometria de la sèrie F...................................... 144

Figura 146 Diagrama diferencial en volum de la granulometria de la serie G. ........................ 145

Figura 147 Diagrama diferencial de la granulometria de la serie H.................................... 146

Figura 148 Diagrama diferencial de la granulometria de la sèrie I......................................... 146

Figura 149 Anàlisis tèrmiques diferencial i gravimètric de la composició A2 ........................ 148

Figura 150 Anàlisis tèrmiques diferencial i gravimètric de la composició B2. ......................... 148

Figura 151 Anàlisis tèrmiques diferencial i gravimètric de la composició C1.......................... 149

Figura 152 Difractometries de les frites de la sèrie A. ............................................................ 150

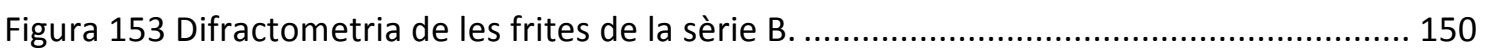

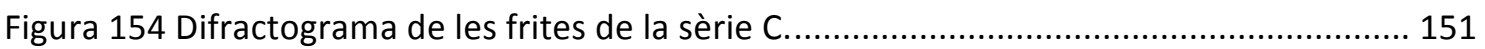

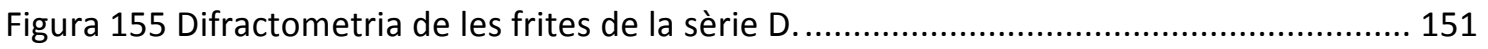

Figura 156 Difractograma de les frites de la sèrie E........................................................... 152

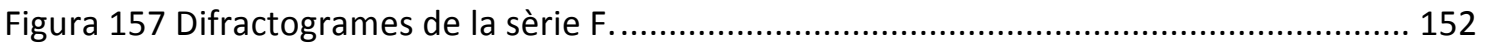

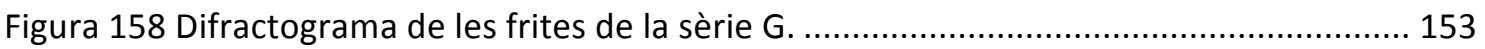


Figura 159 Difractograma de les frites de la sèrie $\mathrm{H}$.

Figura 160 Difractograma de les frites de la sèrie I............................................... 154

Figura 161 Difractogrames de les frites de la sèrie J................................................... 154

Figura 162 Difractograma de la composició A2 amb 1 hora de manteniment a 900, 1000 i $1200 \div$ C.

Figura 163 Difractograma de la composició A3 amb 1 hora de manteniment a 900, 1000 i $1200^{\circ} \mathrm{C}$.

Figura 164 Difractograma de la composició A4 amb una hora de manteniment a 900, 1000 i $1200 \circ \mathrm{C}$.

Figura 165 Difractograma de la composició B2 amb una hora de manteniment a 900, 1000 i 1200 ㄷ.

Figura 166 Difractograma de la composició B3 amb una hora de manteniment a 900, 1000 i $1200^{\circ} \mathrm{C}$.

Figura 167 Difractograma de la composició C1 amb una hora de manteniment a 900, 1000 i 1200 으.

Figura 168 Difractograma de la composició C2 amb una hora de manteniment a 900, 1000 i 1200 ㅇ….....

Figura 169 Difractograma de la composició D1 amb una hora de manteniment a 900, 1000 i 1200 ․․

Figura 170 Difractograma de la composició D2 amb una hora de manteniment a 900, 1000 i $1200 \div$ C.

Figura 171 Difractograma de la composició D3 amb una hora de manteniment a 900, 1000 i 1200 ㄷ․

Figura 172 Difractograma de la composició D4 amb una hora de manteniment a 900, 1000 i 1200 …

Figura 173 Difractograma de la composició D5 amb una hora de manteniment a 900, 1000 i 1200 …

Figura 174 Difractograma de la composició E2 amb una hora de manteniment a 900, 1000 i 1200 ….....

Figura 175 Diractograma de la composició F1 amb una hora de manteniment a 900, 1000 i 1200 으.

Figura 176 Difractograma de la composició F2 amb una hora de manteniment a 900, 1000 i 1200 ㄷ. 
Figura 177 Difractograma de la composició F3 amb una hora de manteniment a 900, 1000 i 1200 ㄷ.

Figura 178 Difractograma de la composició F4 amb una hora de manteniment a 900, 1000 i 1200 ㄷ.

Figura 179 Difractograma de la composició G1 amb una hora de manteniment a 900, 1000 i $1200 \circ$ C.

Figura 180 Difractograma de la composició G2 amb una hora de manteniment a 900, 1000 i $1200 \circ \mathrm{C}$.

Figura 181 Difractograma de la composició H1 amb una hora de manteniment a 900, 1000 i $1200 \circ \mathrm{C}$.

Figura 182 Difractograma de la composició H2 amb una hora de manteniment a 900, 1000 i $1200 \circ \mathrm{C}$.

Figura 183 Difractograma de la composició J2 amb una hora de manteniment a 900, 1000 i 1200 ㄷ.

Figura 184 Diagrama de Ginsberg de la serie A. 166

Figura 185 Diagrama de Lebedeva de la serie A. 166

Figura 186 Diagrama de Raschin-Tschetveritkov de la serie A. 167

Figura 187 diagrama de Ginsberg de la serie B. 167

Figura 188 Diagrama de Lebedeva de la serie B. 168

Figura 189 Diagrama de Raschin-Tschetveritkov de la serie B. 168

Figura 190 Diagrama de Ginsberg de la serie C. 169

Figura 191 Diagrama de Lebedeva de la serie C. 169

Figura 192 Diagrama de Raschin-Tschetveritkov. 170

Figura 193 Diagrama de Ginsberg de la serie D. 170

Figura 194 Digrama de Lebedeva de la serie D. 171

Figura 195 Diagrama de Raschin-Tschetveritkov de la serie D. 171

Figura 196 Diagrama de Ginsberg de la serie E...... 172

Figura 197 Diagrama de Lebedeva de la serie E.

Figura 198 Diagrama de Raschin-Tschetveritkov de la serie E.

Figura 199 Diagrama de Ginsberg de la serie F. 
Figura 200 Diagrama de Lebedeva de la serie F.

Figura 201 Diagrama de Raschin-Tschetveritkov de la serie F.

Figura 202 Diagrama de Ginsberg de la serie G.

Figura 203 Diagrama de Lebedeva de la serie G.

Figura 204 Diagrama de Raschin-Tschetveritkov de la serie G. 176

Figura 205 Diagrama de Ginsberg de la serie H. 176

Figura 206 Diagrama de Lebedeva de la serie $\mathrm{H}$. 177

Figura 207 Diagrama de Raschin-Tschetveritkov de la serie H. 177

Figura 208 Diagrama de Ginsberg de la serie I. 178

Figura 209 Diagrama de Lebedeva de la serie I. 178

Figura 210 Diagrama de Raschin-Tschetveritkov de la serie I. 179

Figura 211 Diagrama de Ginsberg de la serie J. 179

Figura 212 Diagrama de Lebedeva de la serie J. 180

Figura 213 Diagrama de Raschin-Tschetveritkov de la serie J: 180 


\section{Introducció.}

Avui en dia és innegable la importància de la recirculació dels residus per tant de valoritzar-los. Un dels mecanismes més utilitzats per a deixar inert i/o reciclar és la vitrificació, que consisteix en el procés de convertir materials en substàncies vítries, normalment a través d'un procés tèrmic. A més, en un món obligat a ser més sostenible, l'estalvi energètic és un imperatiu alhora de processar materials.

En aquest treball es pretén de reduir el consum energètic, millorant el rang de cocció per dues bandes. Per una part, el fet de que el material reciclat que s'introdueix siga vitrificat, no tinga estructura cristal·lina, permet de reduir la temperatura de fusió de les composicions finals respecte de les que s'obtindrien en el cas d'utilitzar matèries primeres totalment cristal·lines [1].

Per un altre costat, la fusió d'aquestes composicions durant la cocció mitjançant la utilització de la tecnologia làser, podria suposar l'eliminació de l'etapa de fritat per a obtenir determinats vidriats. 


\subsection{La tecnologia convencional de fabricació d'esmalts.}

La tipologia i la composició dels esmalts s'ha anat modificant al llarg dels anys, adaptant-se als avanços tecnològics [2]. Així, no es pot pretendre utilitzar els mateixos esmalts per a coccions que duren diversos dies com per a productes que es produeixen per monococció en poc més de mitja hora. Aquestes variacions de composicions i tècniques de producció al llarg de la història s'estudien per mitjà de la ciència de

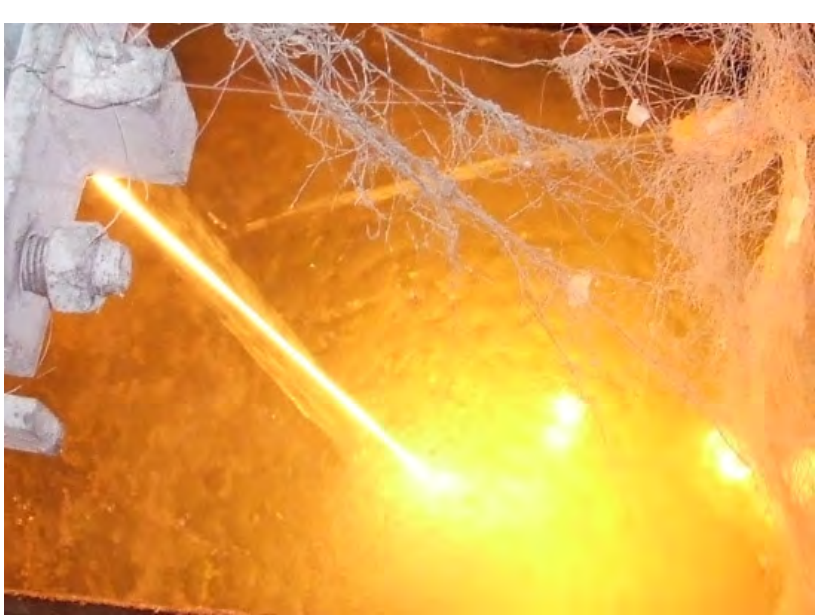
l'arqueometria [3].

Per a poder fabricar esmalts, es pot partir de matèries primeres, amb diferents estructures cristal lines, o es pot partir de material totalment vidriat. Usualment aquest material que es produeix industrialment per aquesta finalitat són les frites. Podem veure un raig de frita fluint sobre un tanc d'aigua a la Figura 1.

Figura 1 Raig de frita fosa.

La recirculació de residus vitrificats, sempre que s'assegure una bona homogeneïtzació i una continuïtat de subministrament en el temps, pot ser una bona alternativa a la utilització de frites per aconseguir els beneficis que presenta l'ús de material vitrificat en la formulació d'esmalts.

Els motius principals per a fritar es poden resumir en [4]:

- Insolubilitzar matèries primeres, estabilitzant reològicament la suspensió de l'esmalt. A més, quan s'insolubilitza, es redueix la toxicitat.

- Eliminar les desgasificacions a la capa d'esmalt durant la cocció. Aquest punt pot ser una font de defectes en uns cicles de cocció cada vegada més curts.

- Augmentar el rang de cocció, de manera que l'esmalt siga més estable durant la cocció, reduint les variacions per gradients de temperatures i millorant l'aspecte final.

\subsubsection{Definició i tipologies d'esmalts.}

Hi ha moltes maneres de classificar els esmalts, baix diferents criteris. Es revisaran algunes de les formes de classificació més habituals.

Per començar, una de les distincions que més importància té des del punt de vista del processat es basa en la cristal·linitat de les matèries primeres utilitzades. Així, es pot 
distingir entre esmalts crus, els que sols utilitzen matèries primeres sense processat tèrmic previ, els esmalts basats en frites i els esmalts basats en residus industrials, que estudiarem en aquest treball.

Quan s'afegeix una capa de recobriment amb una composició pareguda al suport, s'anomena engalba, i pot anar recoberta per un esmalt o quedar com a decoració final.

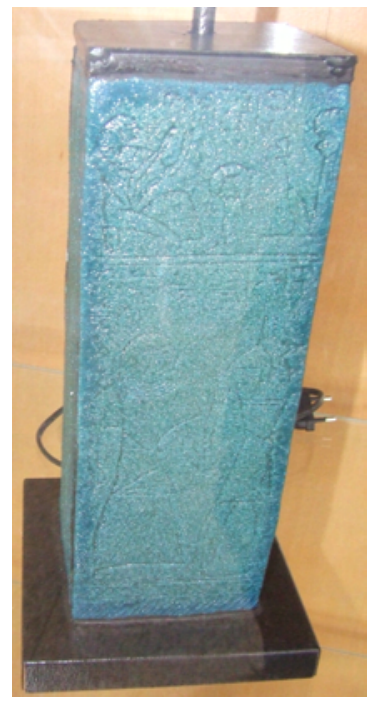

Un altra de les maneres de classificar-los és segons els seus components principals. En aquest sentit, cal destacar que ha hagut una variació des de l'època dels romans, que gastaven com a base esmalts silico-sòdics [5], passant pels esmalts amb alt contingut en plom que s'han utilitzat des de l'edat mitjana fins els darrers anys del segle XX [6], [7].

Aquesta tendència s'ha modificat profundament durant els últims anys, ja que s'ha produït una progressiva eliminació d'aquest material per motius de toxicitat i medi ambientals. A la Figura 2 es mostra una peça moderna decorada amb un material que s'utilitzava en l'antiguitat, anomenada pasta egípcia.

Figura 2 Peu de llum decorat amb pasta egípcia.

Per altra banda, es poden classificar segons la funcionalitat de la peça final. Així, en el cas de taulells ceràmics, es pot distingir usos i funcionalitats molt diferents, que exigeixen unes propietats tècniques específiques en alguns casos:

1. Per a paviments, es demana productes gresificats o productes en grans espessors que presenten altes resistències mecàniques. En canvi, per a revestiments de parets, es demana productes amb gran estabilitat dimensional, com són els productes porosos.

2. Per funcionalitats especials, com són els paviments antirelliscades [8], taulells bactericides, esmalts nanoestructurats multifuncionals [9], etc.

3. En general, els requeriments tècnics seran diferents si el producte final està pensat per a interiors o exteriors de vivendes [10].

Cal tenir present que la temperatura de cocció influirà de forma decisiva en l'aspecte final que presenta la superfície d'un esmalt, de manera que diferents tractaments tèrmics donaran lloc a vidriats amb superfícies diferents [11]. Si es considera la seva classificació per l'acabat superficial que presenta un vidriat sotmès a un determinat cicle, es pot tenir en compte distints efectes:

1. Superfície brillant o mat. Depèn de que hi haja cristalls presents (mat) o no (brillant) a la superfície. 
2. Fenòmens de transparència o opacitat. Depèn dels cristalls existents o no al cos del vidriat.

3. Altres: Capacitat de penetració, llustre, aspecte metàl·lic... [12]-[14]

Si es classifica segons la seva estructura interna, es pot considerar:

\section{1) Esmalts vitris.}

En certes publicacions, de tipus artístic, es refereixen a aquest tipus d'esmalts com vernissos [15]. Són esmalts que presenten una estructura totalment vítria, homogènia, de manera que els vidriats finals són totalment transparents.

Però no tots els esmalts transparents presenten una estructura vítria. Es possible que les fases que es formen tinguen índex de refracció molt similars o que les gotes o partícules formades siguen tant menudes que no s'aprecien a la vista. Açò permet que la major part de la llum siga transmesa i sols una xicoteta part siga reflectida difusament [16].

Una de les formes d'evitar la cristal-lització és que la viscositat de la matriu vítria siga molt elevada en els rangs que comença la desvitrificació, així els àtoms no es poden moure lliurement per a ordenar-se.

Hi ha dos tipus de desvitrificacions, la heterogènia, que depèn de la superfície de les partícules, i la homogènia, que es du a terme volumètricament, indistintament de la granulometria de les partícules. Els sistemes més estudiats són els de desvitrificació heterogènia [17], ja que en materials particulats l'efecte de la granulometria que s'obté al molturar afavoreix la nucleació heterogènia i dificulta el control del creixement cristal·lí.

\section{2) Opalescència (esmalts en separació de fases, amb gotes liquades).}

En aquest apartat estudiarem l'etapa que es duu a terme inicialment per tal de formar cristalls. La separació de fases consisteix en la formació de gotes d'un líquid insoluble en el sí de la matriu, també líquida. Aquest procediment, el liquat, pot utilitzar-se per a opacificar esmalts, si els índex de refracció de les fases són molt diferents. En el cas de vidre i esmalts, el terme liquat es refereix a un procés de segregació, amb formació de dues fases separades. Es pot trobar un exemple en el sistema $\mathbf{N a}_{2} \mathbf{O}-\mathbf{S i O}_{2}$, o en la concentració alterada d'òxids amfòters $\left(\mathbf{R}_{\mathbf{2}} \mathbf{O}_{\mathbf{3}}\right)$ amb alcalinoterris (RO) en vidres de borosilicats [18].

Aquest procés de liquat en els vidres transparents, pot durar rangs des temps molt dispars per a formar-se, des de pocs segons, com és el cas del sistema $\mathbf{C a O}-\mathbf{A l}_{\mathbf{2}} \mathbf{O}_{3}-\mathbf{S i O}_{\mathbf{2}}$ 
(que conté gotes amb mida entre $\mathbf{0 , 0 5}$ i $\mathbf{0 , 4}$ micròmetres de diàmetre) fins una duració de varies hores com es troba al mateix sistema quan es provoca la segregació entre $\mathbf{7 5 0} \mathrm{i}$ $\mathbf{8 0 0}^{\circ} \mathrm{C}$. Els canvis en els nivells de concentració dels òxids que participen en el procés de liquat, poden fer que les gotes liquades cristal·litzen. Per exemple, les espineles de zinc en els silico-bor-aluminats amb baixos continguts en alcalins. El procés de formació de gotes en vidres pot ser explotat com una forma d'obtenir opacitat.

Alguns exemples de sistemes que produeixen aquest efecte són:

- $\mathrm{CaO} . \mathrm{B}_{2} \mathrm{O}_{3} \cdot 2 \mathrm{H}_{2} \mathrm{O}$

- $\mathrm{Li}_{2} \mathrm{O}-\mathrm{B}_{2} \mathrm{O}_{3}-\mathrm{SiO}_{2}$

- $\mathrm{Li}_{2} \mathrm{O}-\mathrm{TiO}_{2}-\mathrm{SiO}_{2}$

- $\mathrm{CaO}-\mathrm{TiO}_{2}-\mathrm{SiO}_{2}$

Altres sistemes amb dues fases líquides metastables estudiats són $\mathbf{N a}_{2} \mathbf{O}-\mathbf{B a O}-\mathbf{S i O}_{2}$. Al sistema $\mathrm{Li}_{2} \mathrm{O}-\mathbf{B}_{\mathbf{2}} \mathrm{O}_{3}-\mathrm{SiO}_{2}$, un contingut entre el $\mathbf{5 - 1 5 \%} \mathrm{Li}_{2} \mathrm{O}$ i un $\mathbf{2 0 - 5 0 \%}$ de $\mathbf{B}_{2} \mathrm{O}_{3}$, pot fer arribar a una forma interesant d'opacitat induïda per liquat basada en al formació de gotes de liquat de entre $\mathbf{0 , 0 2 - 0 , 7}$ micròmetres de diàmetre. La fase de vidre uniforme és rica en silici, i la matriu s'enriqueix en òxid bòric, amb la conseqüent modificació de l'índex de refracció. El sistema $\mathbf{C a O}-\mathbf{T i O}_{2}-\mathbf{S i O}_{2}$ te grans gotes liquades, i la diferència en l'índex de refracció resultant és també gran, tant que el vidres són intensament opacs.

A més dels diagrames de fases experimentals, s'han estudiat models teòrics per a calcular les línies de separació entre fases de dos líquids, basant-se en les relacions termodinàmiques obtingudes per les equacions dels potencials químics dels líquids en equilibri, en concret, del sistema $\mathbf{B a O}-\mathbf{L i}_{2} \mathbf{O}-\mathbf{S i O}_{2}$ [19].

\section{3) Vitroceràmics transparents i opacs:}

Els vitroceràmics són materials policristal·lins de gra fi que es formen quan composicions adequades de vidre són tractades tèrmicament amb la finalitat d'obtenir una cristal·lització controlada de l'energia més baixa, l'estat cristal·lí [20]. Aquesta desvitrificació depèn de dos factors principalment, la composició i el tractament tèrmic. Per a obtenir un bon desenvolupament vitroceràmic interessa que la temperatura de sinterització i la de cristal·lització estiguen en rangs diferents. Es pot obtenir entre un 50-95\% de volum de microestructura cristal-lina en el sí d'una matriu vítria. Les millors propietats es troben quan la cristal·lització és superior al $90 \%$ de la massa vítria inicial amb mida de partícula inferior a 1 micròmetre [21].

En la dècada de 1990, hi havia un creixent interès en el desenvolupament de frites que són capaces de cristal-litzar en la cocció, donada la necessitat de millora en les propietats mecàniques i químiques dels taulells esmaltats [22].

Els esmalts a partir de frites que obtenen una estructura vitroceràmica han esdevingut recentment una de les formes d'obtenir propietats mecàniques, químiques $i$ tèrmiques superiors. Aquestes propietats vénen donades per la formació de cristalls uniformes i menuts, entre $\mathbf{0 , 2}$ i 0,3 micròmetres de diàmetre integrats en la fase vítria. D’aquesta 
manera s'aconsegueixen materials amb pocs defectes $\mathrm{i}$ gran fortalesa. Amb aquesta estructura vitrocristal-lina s'obté una opacitat elevada amb un baix consum de matèries primeres opacificants i amb un aspecte molt brillant i d'elevada blancor.

Per tal de conèixer la capacitat de diferents composicions de produir vitroceràmics, hi ha diagrames que representen diferents models predictius. Es tracta d'uns diagrames orientatius experimentals que es van obtenir a partir de refredaments lents del material fos, molt utilitzats anys enrere per a residus basàltics i cocció petrúrgica. El primer diagrama, el de Ginsberg, considera que es pot conèixer el paper exercit pels cations en el procés de cristal-lització [23]. El diagrama de Raschin-Tschetveritkov i el de Lebedeva ens donen informació sobre la natura de les fases cristal·lines que es formen. Per a estudiar-los, cal partir del percentatge en pes d'òxids de les diferents composicions [24].

El primer mètode predictiu, de Ginsberg (1959), indica si les composicions són adequades per a produir vitroceràmiques a partir de la proporció dels percentatges en pes dels seus òxids en un digrama ternari. Per açò, utilitza les coordenades: SAL, que expressa la quantitat de sílice i alúmina que conté la mostra; CAFEM, la quantitat dels òxids de calci, ferro i magnesi hi ha i ALK, la quantitat d'òxid de sodi i potassi que conté l'esmalt, com es pot veure a Figura 3. Per a formar vitroceràmics SAL ha d'estar entre el 60 i el 70\% en pes. Per baix d'aquesta zona, es considera que hi ha massa modificadors en el vidriat per a permetre una bona desvitrificació. Quan estan per dalt, és a dir, si la quantitat de sílice i alúmina és superior al $\mathbf{7 0 \%}$, es considera que la composició és massa rígida, té massa viscositat i és massa estable per afavorir el procés de cristal·lització.

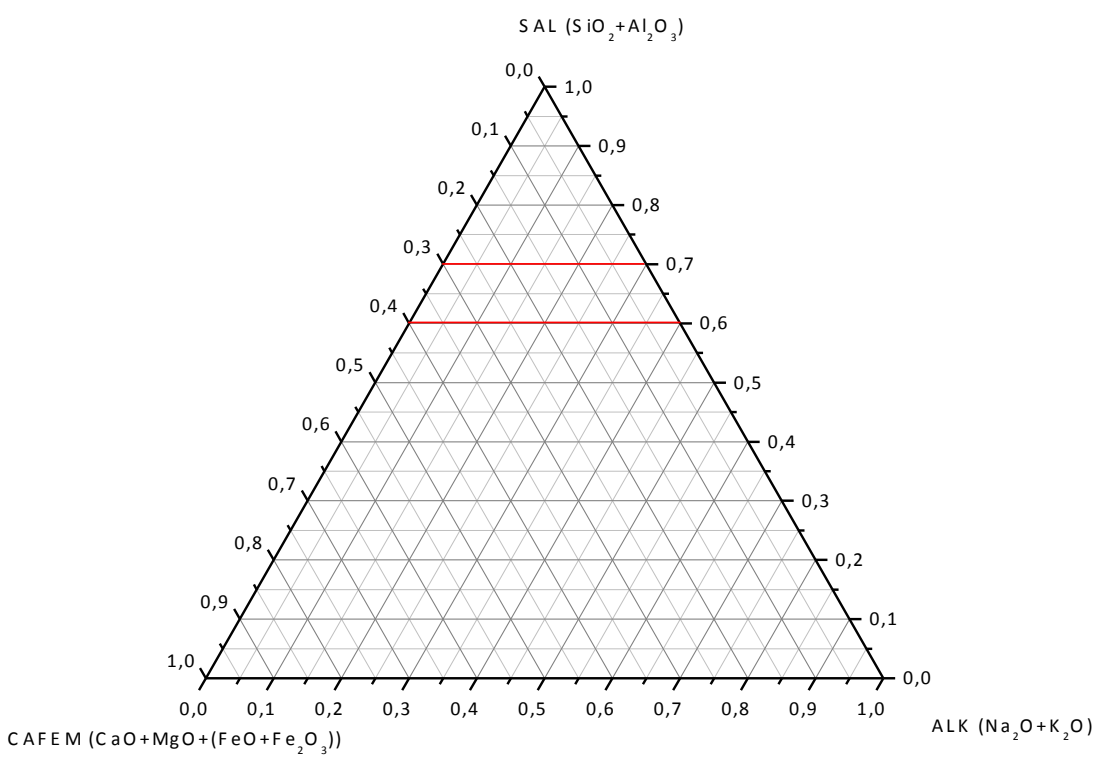


Quant al triangle de Raschin-Tschetveritkov (1964), modificat per Kanazirsky i Yotzo en 1972, presenta tres coordenades: $\mathbf{Q}, \mathbf{L}$ i $\mathbf{M}$, com s'observa a la Figura 4. L'extrem $\mathbf{Q}$ és la quantitat de sílice, $\mathbf{L}$ la suma d'alúmina, òxid de sodi i de potassi i $\mathbf{M}$ la dels òxids de calci, magnesi, ferro i titani. Es representa un triangle entre les composicions teòriques del piroxè, el feldspat i TSCH $\left(\mathbf{C} \mathbf{a A I S i} \mathbf{O}_{2} \mathbf{O}_{6}\right)$. Les composicions situades a la part superior del triangle, riques en sílice, es consideren massa viscoses en fos per a obtenir una bona desvitrificació. Quan les composicions s'apropen al triangle central i dintre d'aquesta zona, es considera que es pot obtenir amb estos materials bons esmalts vitroceràmics. Per altra banda, si la composició estudiada es troba a la part inferior, es considera que conté massa modificadors i que pot precipitar oliví durant el procés, cosa que empitjoraria les propietats obtingudes.

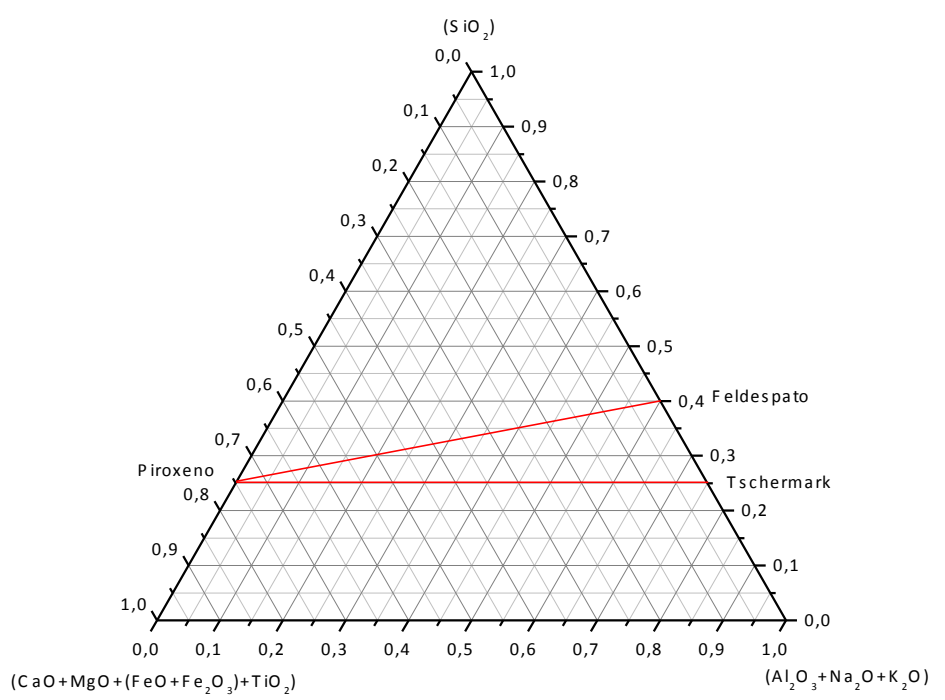

Figura 4 Diagrama de Raschin-Tschetveritkov.

El diagrama Lebedeva és derivat del diagrama anterior, tenint en compte el paper dels cations modificadors en el procés de cristal·lització, de manera que parlem de CA $\left(\mathrm{Ca}^{2+}\right), \mathbf{F E}\left(\mathrm{Fe}^{2+}\right)$ i $\mathbf{M G}\left(\mathrm{Mg}^{2+}\right)$. En aquest cas el diagrama es divideix en sis regions en funció de l'aparició de fases cristal·lines, com es pot veure a la Figura 5. A la regió I estan els de magnetita, $\mathbf{F e}_{3} \mathbf{O}_{4}$, envoltada de cristalls de piroxè esferulítics. A la regió II, la magnetita no és la fase primària, sinó que coexisteixen piroxè i magnetita secundaria al mateix temps. Les regions III a $\mathbf{V}$ són iguals en microestructura, però varien en la fase primària. Si $\mathbf{L}>\mathbf{M}$, la plagiòclasi cristal litza com la fase primària; pel contrari, si a la composició $\mathbf{L}<\mathbf{M}$, el piroxè és la primera fase. Finalment, la zona VI produeix olivina, que no és adequada per a la producció de vitroceràmica [25]. 


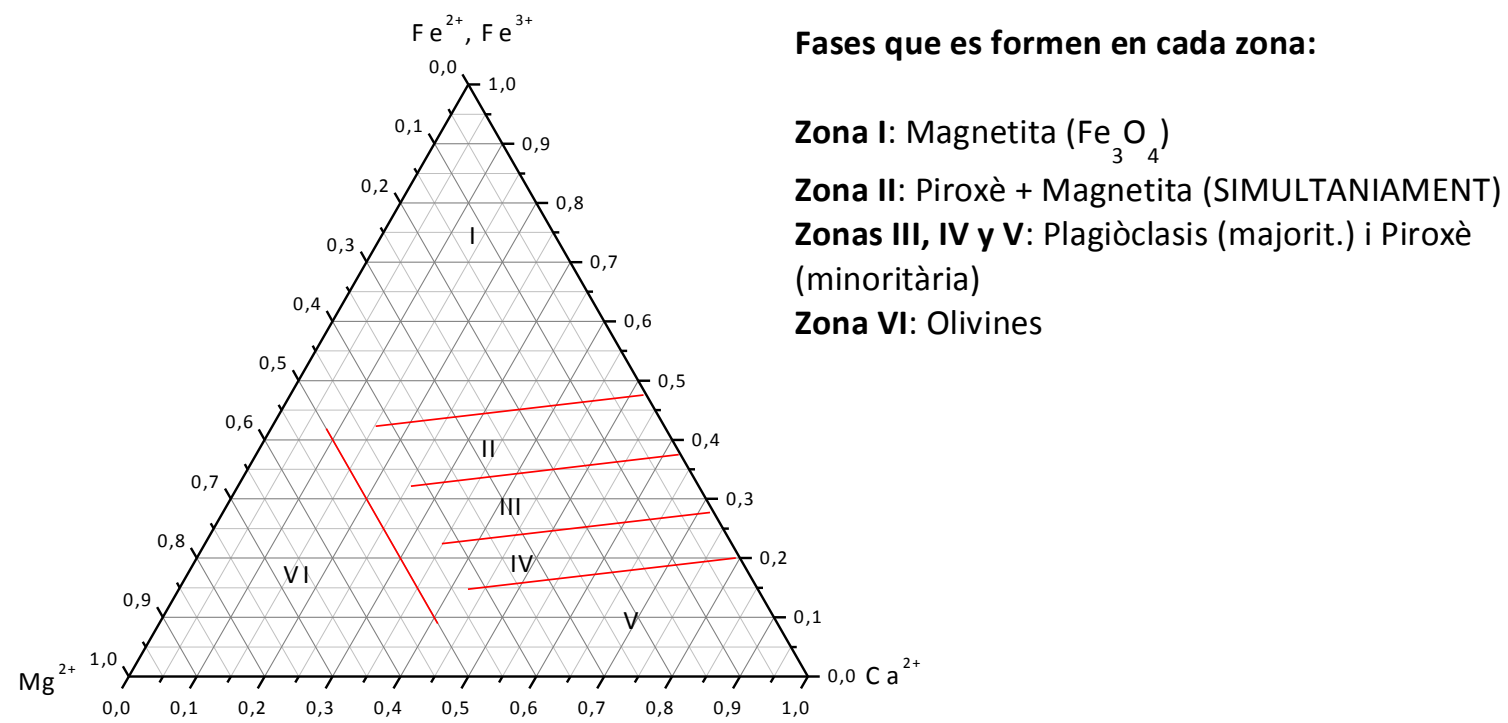

Figura 5 Diagrama de Lebedeva.

Cal destacar que els tres mètodes són complementaris entre si i s'han d'aplicar conjuntament per a obtenir informació correcta. Per tant, a partir de la composició en pes dels òxids que formen un material, el mètode Ginsberg ens dóna una idea del paper que exerceixen els cations en el procés de cristal-lització mentre que els mètodes Raschin-Tschetveritkov i Lebedeva ens donen informació sobre la naturalesa i la seqüència de cristal·lització.

Per a obtenir materials vitroceràmics, s'utilitzen principalment tres mètodes tèrmics descrits en bibliografia [26]:

1. Mètode convencional en dos estadis. La primera estada es fa a la temperatura de màxima nucleació i la segona a la de màxim creixement cristal·lí.

2. Mètode convencional modificat en un estadi. El manteniment es fa sobre una temperatura a la qual es formen nuclis, però a la què també hi ha creixement cristal·lí.

3. El mètode petrúrgic. Es parteix d'un material totalment fos i es deixa gelar lentament, de manera que els cristalls creixin durant el refredament lent.

En el cas d'esmalts vitroceràmics, el tractament tèrmic ve donat pel cicle de cocció del suport.

\section{4) Esmalts cristal·lins:}

Els esmalts cristal·lins s'han utilitzat per aconseguir efectes especials de decoració en ceràmica artística. La base transparent de l'esmalt conté cristalls amb mides i colors diferents, superiors a $1 \mathrm{~mm}$ de llargària. Quant els cristalls són menuts, les propietats tècniques milloren, però quan són majors, com en aquests esmalts, el fet de què tinguen 
un creixement acicular a partir de la base, fa que l'ancoratge dels cristalls a la matriu siga feble i les propietats tècniques es redueixen. Per altra banda, la dispersió dels cristalls dona opacitat, color i característiques diferents a la superfície esmaltada.

Durant la cocció, els cristalls se separen del vidre fos. Aquesta desvitrificació comença a la superfície i a una temperatura donada per la composició. Pot cristal·litzar més d'una fase diferent, que se segreguen del vidre a diferents temperatures durant el refredament. Aquest procés és millor quan la viscositat és molt baixa, així els cristalls poden créixer suficientment per a poder distingir-se a simple vista. Així trobem que la coloració pot ser diferent en la matriu i en els vidres, que poden incorporar en diferents proporcions els òxids de metalls fins la saturació [18].

\section{a) Composicions.}

En funció de la capacitat de cristal·lització poden formar-se més o menys cristalls, a una velocitat que serà màxima a una temperatura que podem conèixer per anàlisi ATD_TG. Els efectes més cridaners s'obtenen quan hi ha pocs nuclis cristal·lins i un grau alt de creixement cristal·lí. D’aquesta manera s'obtenen cristalls individuals de mida gran que destaquen sobre la matriu vítria. En el cas contrari, quan hi ha molts nuclis però baix grau de creixement, s'obté un esmalt mat $\mathrm{o}$, si són molt menuts, vitroceràmic.

Per aconseguir un grau de creixement gran, com s'ha destacat abans, cal tenir una viscositat baixa. Així, cal reduir la quantitat d'alumini i d'òxid de magnesi de l'esmalt i augmentar els alcalins, els altres alcalinoterris i la proporció d'òxid de bor. De fet, normalment contenen a la seva composició òxid de zinc, òxid de titani, òxid fèrric, òxid cròmic i òxid de vanadi, a més a més de compostos basats en molibdè, tungstè, beril li $\mathrm{i}$ liti, tots ells bons formadors de cristalls. Aquesta combinació, per tant, tindrà una bona formació i també amb un bon creixement a baixes viscositats. Tradicionalment s'ha fritat el material per a poder obtenir un millor control del creixement.

\section{b) Vidriats cristal-lins amb aventurines.}

Com que part dels residus que emprarem (l'escòria i la cendra) tenen un alt contingut en òxid de ferro, destaquem aquest tipus d'esmalts, que permetria de valoritzar els materials reciclats.

En aquests esmalts s'aprecien cristalls fins d'òxid de ferro es separen de la matriu vítria, reflectant una brillantor dorada en cocció oxidant. Aquest aspecte dels cristalls s'ennegreix en atmosfera reductora. Una diferència important amb la resta de esmalts cristal·lins és que els cristalls es mantenen en el sí del vidriat, en lloc de sobreeixir per la seva superfície.

La formació del vidres d'aventurina està basada en la sobresaturació de vidres bàsics

$\mathrm{amb}$ òxids de ferro. És molt important anar amb compte amb la proporció d'òxid fèrric 
per a evitar la cristal-lització superficial: es formen hematites $\left(\mathbf{F e}_{2} \mathbf{O}_{3}\right)$ i faialita $(\mathbf{2 F e O}$. $\mathbf{S i O}_{2}$ ). L'òxid fèrric que està dissolt en el líquid bàsic durant la cocció precipita en forma de cristalls d'hematites. Un refredament ràpid des d'altes temperatures promou la recristal·lització d'òxid de ferro en xicotets cristalls d'hematites. A la Figura 6 hi ha una peça amb brillantor metàl·lica.

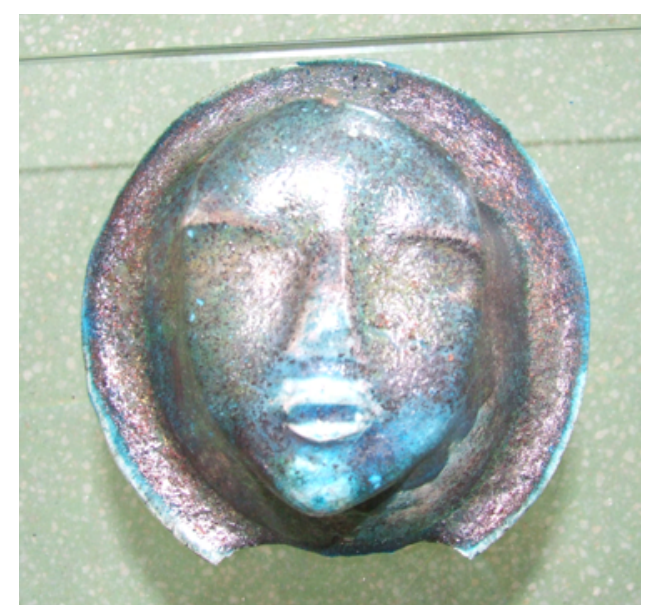

Figura 6 Peça amb brillantor metàl-lica.
Depenent de la temperatura de cocció, una quantitat típica de solubilitat estaria pel $\mathbf{6 \%}$ de $\mathrm{Fe}_{2} \mathrm{O}_{3}$ en el vidre. Si el refredament és molt lent, el $\mathrm{Fe}_{2} \mathrm{O}_{3}$ que sobra, es diposita a la superfície de l'esmalt. Un altre factor que afecta al resultat és la presència d'altres components cristal-litzadors en la composició del vidre, com els fosfats [27].

Quan la quantitat d'òxid de ferro present a l'esmalt és molt alta, els esmalts pòden ser conductors $\mathrm{o}$ presentar propietats ferromagnètiques [28].

\subsubsection{Matèries primeres.}

De la mateixa forma que hi ha diferents criteris per a classificar els esmalts, les matèries primeres poden ser classificades per:

1. Composició química i/o estructura: Ens dóna informació sobre les reaccions principals que tenen lloc durant la cocció i sobre la solubilitat en aigua:

a. Silicats: Són insolubles. S'utilitzen àmpliament en la producció de frites i esmalts. Podem trobar:

i. Feldspats alcalins de sodi i potassi, Nefelina Sienita.

ii. Silicats de calci (wol·lastonita) i magnesi (talc).

iii. Silicat de zirconi.

iv. Quars i caolins.

b. Carbonats, descomponen produint $\mathbf{C O}_{2}$ :

i. Alcalins: sodi, liti i potassi. Tots ells solubles en aigua.

ii. Alcalinoterris: magnesi, calci, estronci, bari i dolomita. Insolubles en aigua.

c. Nitrats: de sodi i potassi. Cal reduir el seu consum a la producció de frites per motius mediambientals, ja que descomponen en gasos tòxics. 
Tampoc és aconsellable el seu ús en esmalts crus, degut a la seva solubilitat en aigua.

d. Òxids d'origen sintètic: de plom, cinc, alúmina, titani i estany, per exemple. Insolubles excepte el de plom, el mini, que a més és molt tòxic, pel que està en desús actualment en la industria.

2. Per l'element principal que aporten a la composició final. D'aquesta manera es pot parlar, per exemple, de minerals que aporten bor (bòrax, àcid bòric, colemanita, ulexita...) o zirconi (arena de zirconi o silicat de zirconi).

Aquesta segona forma de classificar, respon a facilitar la formulació de vidres i esmalts. Per altra banda, segons la funció que desenvolupen durant la fusió, es poden agrupar els components de un vidre o esmalt en quatre grups [29]:

1. Vitrificants: són els òxids formadors de xarxa.

a. Sílice. És el component principal de la majoria dels vidres i esmalts industrials. Com presenta canvis al·lotròpics amb fortes variacions dimensionals, aquestes s'han de tenir en compte al dissenyar el procés de fabricació.

b. Bor. S'utilitza conjuntament amb altres formadors, per la seva alta solubilitat.

c. Fòsfor. També forma vidres solubles, amb propietats òptiques especials.

2. Fundents: són els que modifiquen la xarxa, rebaixant la temperatura de fusió. Els alcalins són més efectius que els alcalinoterris.

a. Sodi. És el més utilitzat. S'introdueix en moltes matèries primeres, amb els condicionants dels gasos que s'emeten (la sal comú produeix clor gasós, molt agressiu) i el contingut en alúmina (que augmenta la viscositat en fos) o ferro (que aportaria color al producte).

b. Potassi. S'utilitzava antigament, a temperatures de processat més elevades.

c. Liti. S'utilitza per obtenir aplicacions òptiques especials, però és molt car, ja que té moltes aplicacions en altres indústries [30].

d. Calci. S'utilitza molt. Provoca desvitrificacions en determinades proporcions, pel que es gasta per a obtenir esmalts mats. 
e. Magnesi. S'introdueix en forma de dolomita o talc per a eliminar la desvitrificació en vidres o vidriats transparents que contenen calci.

f. Bari. Augmenta la densitat, l'índex de refracció i la brillantor del vidre o vidriat, i també el rang de treball en fos.

3. Estabilitzants: poden actuar com a formadors o com a modificadors.

a. Alumini. Regula la viscositat en fos i augmenta l'estabilitat química, així que s'utilitza en proporcions superiors al $3 \%$ en vidres que han de suportar altes temperatures en el seu ús.

b. Oxid de plom. Tot i que redueix molt la viscositat en fos i millora les propietats òptiques i la sonoritat, s'ha de reduir el seu consum per motius mediambientals.

c. Oxid de zinc. Normalment s'addiciona en proporcions baixes, provocant una modificació de les propietats òptiques [31].

4. Components secundaris: són els que s'afegeixen amb finalitats específiques.

a. Opacificants:

i. Òxid d'estany.

ii. Òxid de zirconi.

iii. Diòxid de titani. Actualment, és un dels opacificants que més s'utilitza [32].

iv. Òxid de ceri.

b. Matificants: per a obtenir aquest efecte s'utilitza alúmina, òxid de calci o de zinc, ja descrits anteriorment.

\subsubsection{Processament i aplicació.}

Els esmalts estan constituïts per matèries primeres, frites i pigments ceràmics, que proporcionen coloració al vidriat. Normalment, es mesclen en aigua i altres additius i es molturen fins arribar a la granulometria adequada per aplicar-se sobre el suport, cru (monococció) o escaldat (bicocció). Les suspensions s'han de regular reològicament per tal d'obtenir una bona aplicació que proporcione una superfície final sense defectes [33]. Hi ha proves per tal d'aplicar en un futur els esmalts en sec, per premsat, o amb impressió digital.

L'aplicació en sec proporciona avantatges tant econòmics com mediambientals, ja que per una part es redueix el consum d'aigua de forma important, tant per a preparar els 
esmalts com per a neteja. A més, per un altra part, permet treballar amb materials solubles, ja que no es perdrien components dissolts en l'aigua que, a més de canviar les propietats del producte final, poden descontrolar l'aplicació al modificar la reologia de la suspensió.

El procés de fabricació de frites comença amb la dosificació de les matèries primeres per confeccionar un lot de fabricació. La Figura 7 és del principi del procés, en la part inferior d'un grup de sitges on s'emmagatzemen diferents materials primeres. Segons la composició que ha de preparar-se, es posa en marxa el sistema de transport pneumàtic que hi ha sota de cada sitja, per portar els materials a través de canonades hermètiques a una bàscula $i$, després de pesada, cada matèria prima continua per la part inferior cap una mescladora. Els lots de fabricació oscil·len entre 750 i $2000 \mathrm{~kg}$, segons instal-lacions. En aquestes operacions s'ha de tenir en compte la granulometria de les matèries primeres, així com que les pesades siguin el més exactes possible.

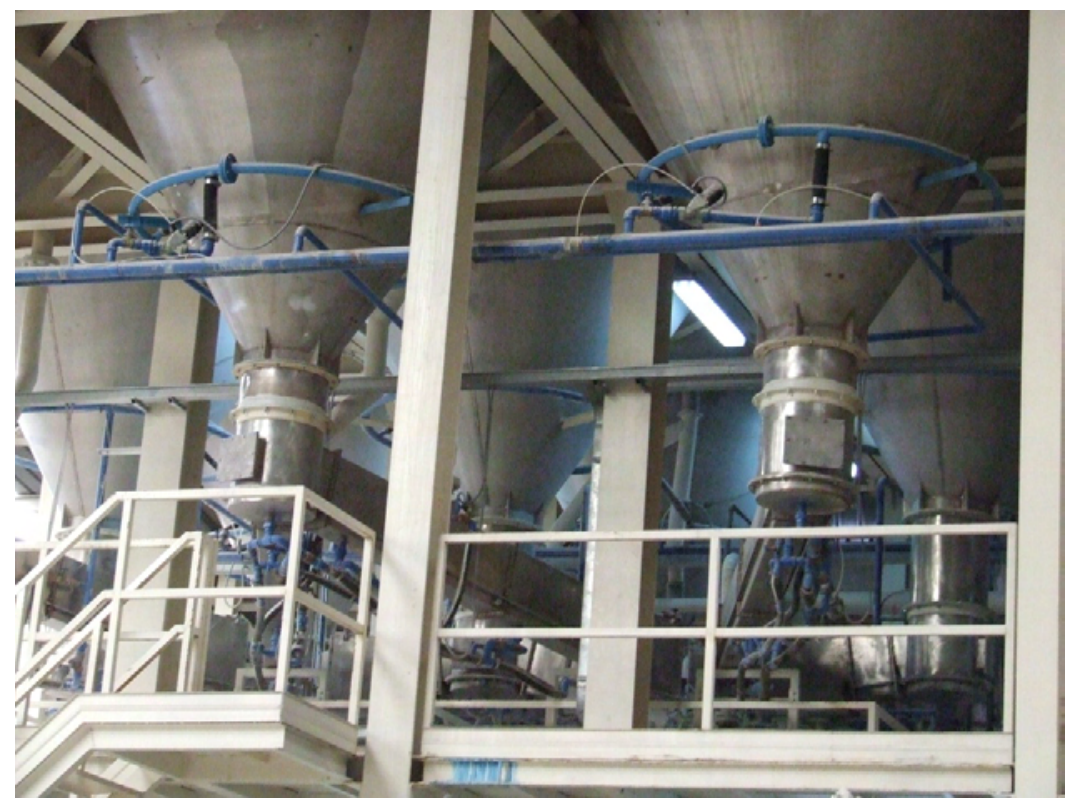

Figura 7 Distribució de material des de sitges fins la mescladora.

Es controla el temps de barrejat per tal d'obtenir resultats òptims. En la producció de frites, els successius lots de matèries primeres es traslladen a una tremuja d'alimentació a la part posterior del forn, que pot emmagatzemar de tres a cinc lots de fabricació. Des d'aquesta tremuja s'alimenta el forn on té lloc la fusió.

L'alimentació de la barreja de fusió al forn es realitza mitjançant un cargol helicoïdal o cargol sense fi, que va introduint progressivament el material en pols al forn. A l'interior del forn de fusió es produeix intencionadament un amuntegament de matèria primera sense fondre, davant de l'alimentador. Aquesta petita muntanya de material s'anirà fonent progressivament dins el forn mentre s'alimenta de l'exterior, mantenint el seu volum constant durant l'operació. D'aquesta manera, s'impedeix que la calor de l'interior del forn, on pot haver-hi una temperatura entre 1300 i $1450^{\circ} \mathrm{C}$, arribe als elements metàl-lics del sistema d'alimentació, cosa que produiria la fusió de la barreja en el seu 
interior i l'engarrotament de les parts mòbils. A la Figura 8 es pot seguir l'esquema de fabricació.

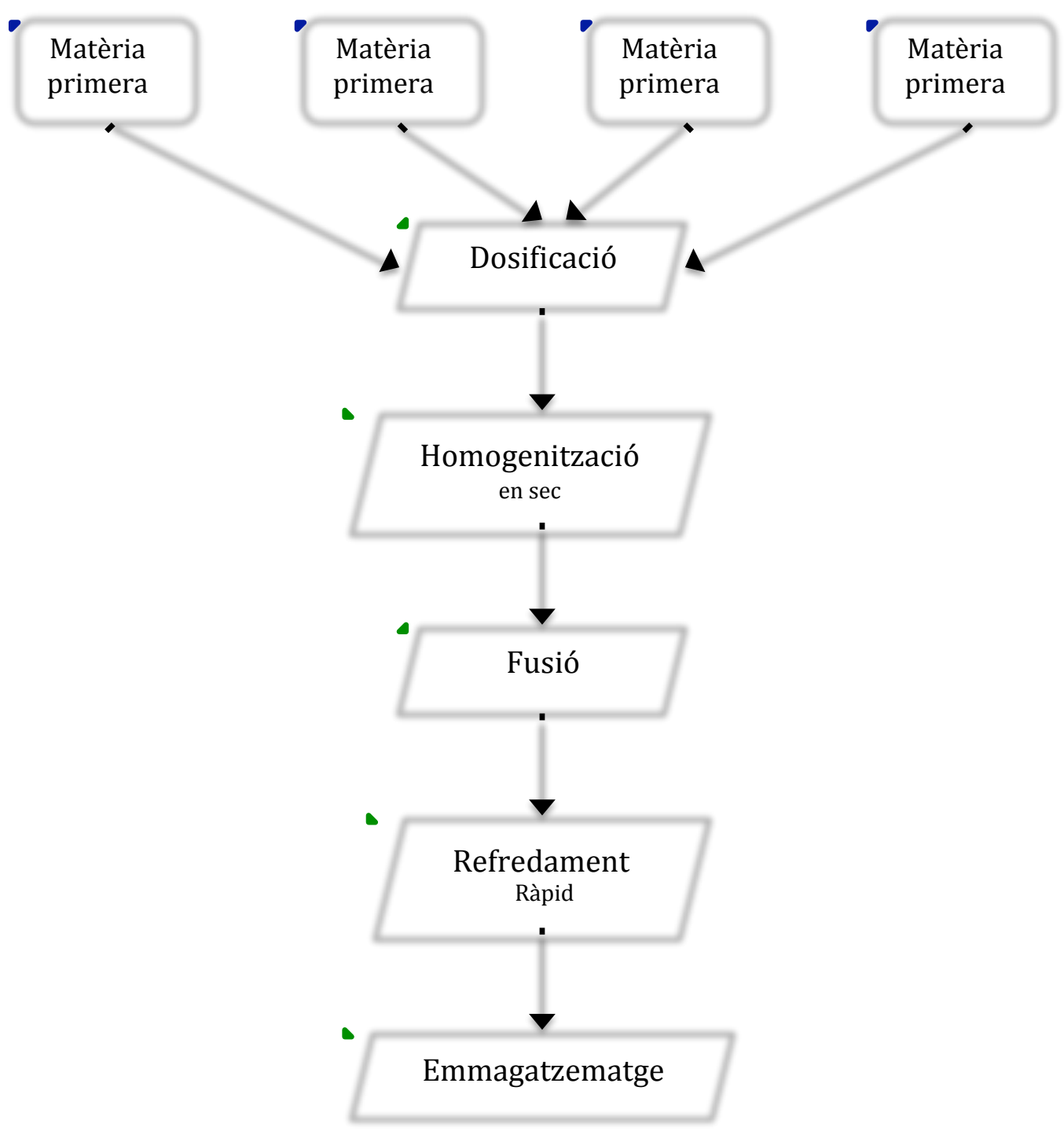

Figura 8 Esquema de fabricació de frites.

El refredament brusc de les frites, a més de impedir desvitrificacions, provoca un trencat del fil de descàrrega en grànuls o escates petites, tallants, de grandàries d'1 a $\mathbf{5}$ mm.

Posteriorment, amb la resta de components dels esmalts, les frites s'apliquen sobre suports ceràmics, de manera que fonen al forn durant la cocció, deixant la superfície llisa i impermeabilitzada. El forn, anomenat de Bacino és allargat i menut, amb un poc d'inclinació que ajuda a que el material circule, com es veu a la Figura 9 que representa el seu funcionament: 


\section{Forn de Bacino}

vista lateral

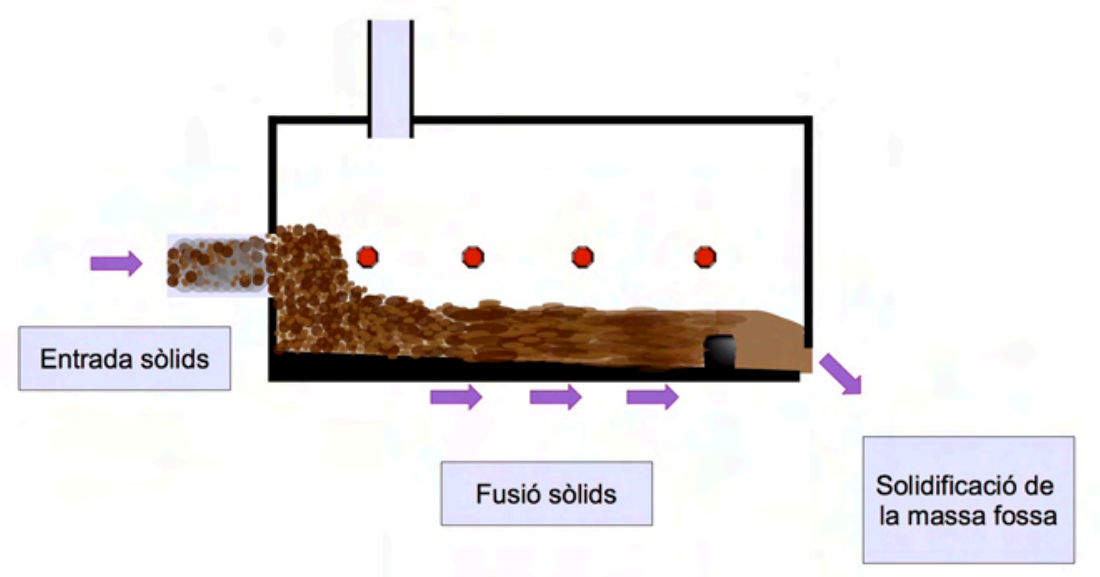

Figura 9 Forn de Bacino.

Les parets del forn de Bacino són de refractari i tenen alguns forats, com una boca de

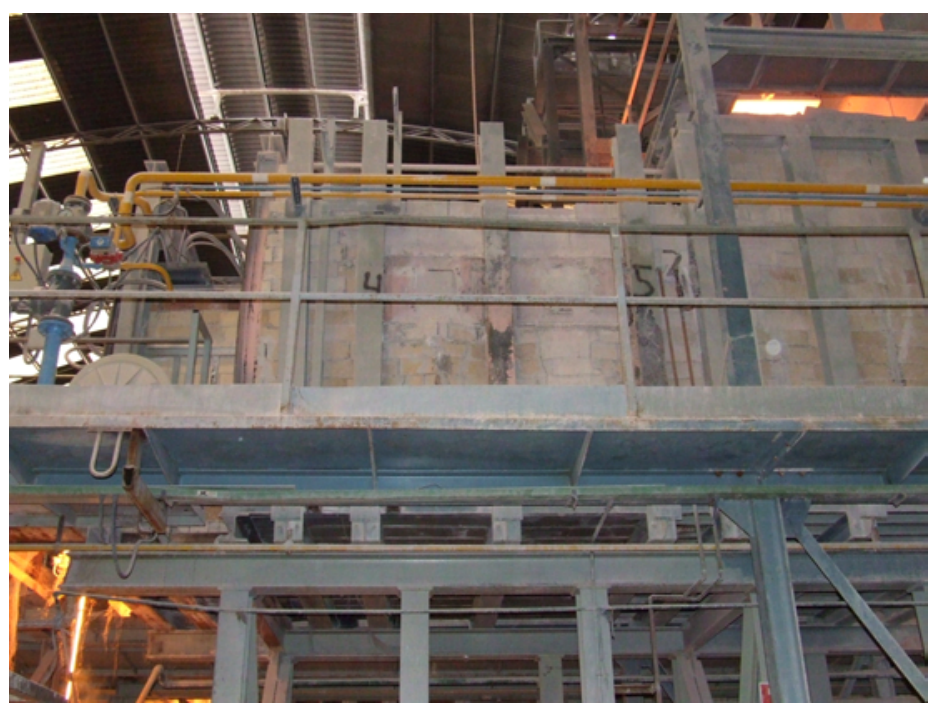
càrrega en la part posterior per a la introducció de les matèries primeres, boques d'allotjament de cremadors, en la seva base hi ha una boca de descàrrega per a la frita fosa i la xemeneia està situada a la part superior. L'estructura sol estar reforçada amb bigues i pilars metàl·lics $i$ una barana protegeix el contorn de possibles caigudes del personal de treball, com es pot veure a la Figura 10.

Figura 10 Forn industrial de fabricació de frites.

Les temperatures de treball estan entre els $\mathbf{1 3 0 0 - 1 5 0 0}^{\circ} \mathrm{C}$ i els gasos de sortida arrosseguen una gran quantitat de calor. Per això s'utilitzen per escalfar l'aire d'entrada als cremadors i reduir el consum energètic del procés.

De forma contínua i progressiva, durant la permanència en el forn, la barreja de matèries primeres va transformant-se en un líquid fos. Així, els elements més fundents dissolen als més refractaris, convertint tota la barreja en un líquid homogeni que avança cap a la boca de descàrrega $\mathrm{i}$ cau per gravetat quan disminueix la seva viscositat, sortint com un líquid de color vermell groguenc, cap al procés de refredament . 
Un altre tipus de forns que es poden utilitzar són els forns discontinus. Consisteixen en un cilindre horitzontal d'acer, revestit internament de material refractari, i dotat d'un sistema de transmissió del moviment que li fa rodar sobre el seu eix a raó de $\mathbf{1}$ a $\mathbf{1 , 5}$ voltes/min. Està perforat en les bases del cilindre per a l'entrada de la flama de combustió i sortida dels gasos residuals, cap a una llar o xemeneia que els condueix a l'exterior.

L'alimentació de matèries primeres es realitza amb el cilindre aturat, per la part superior, amb una tremuja. Un cop carregat comença el procés d'escalfament i de gir del cilindre per accelerar la fusió de les matèries primeres i convertir-les en un líquid fos. Un cop hi ha la frita fosa s'atura el cilindre amb la boca a la part inferior, i es descarrega el líquid viscos. Fa anys s'utilitzava per a producció (entre 500 i 1000kg per fusió), i encara pot quedar alguna instal·lació així, però en l'actualitat només s'utilitzen prototips d'aquests forns, de mida petita, per a proves de frites amb una capacitat de càrrega de $\mathbf{5 0}$ $\mathrm{kg}$ màxim.

El refredament i descàrrega de la frita es realitza majoritàriament abocant el raig de

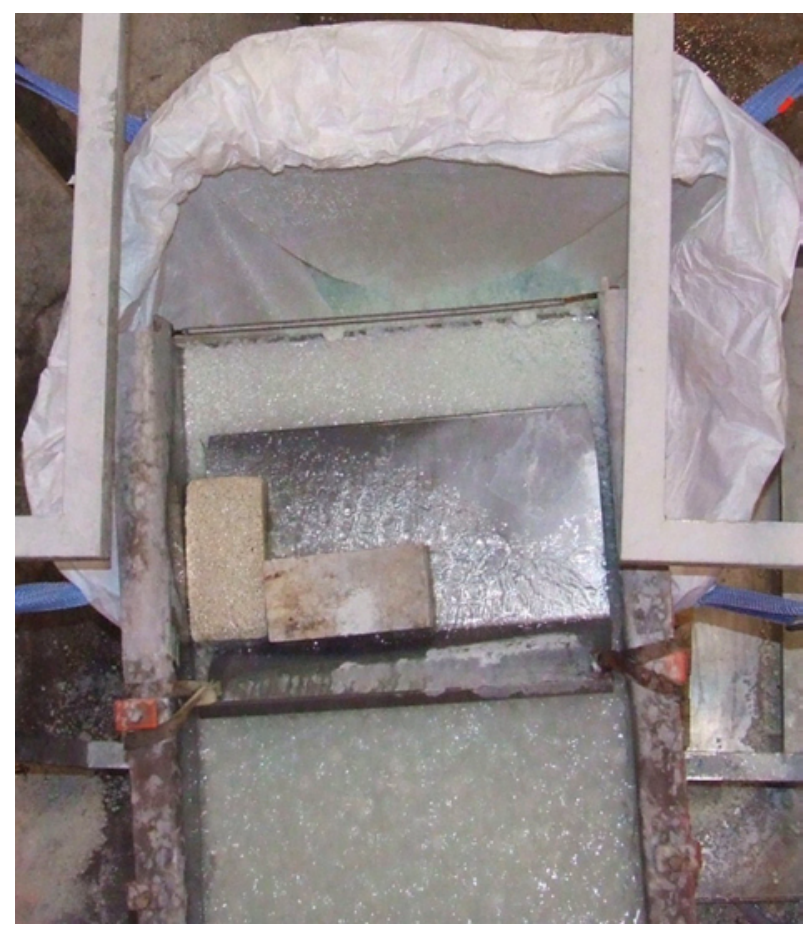
líquid fos sobre un dipòsit d'aigua o es descarrega sobre una cadena d'acer inclinat per on circula una llengua d'aigua de refredament, com s'aprecia a la Figura 11. El contrast tèrmic entre els $\mathbf{1 3 0 0}^{\circ} \mathrm{C}$ de la frita fosa i els 40 a $60^{\circ} \mathbf{C}$ de l'aigua de refrigeració, produeix un trencament de la llengua de líquid viscós en petits trossos de vidre irregular, que són aptes per a la mòlta $\mathrm{i}$ per al seu transport. L'aigua d'aquest dipòsit es renova $\mathrm{i}$ depura contínuament, i passa a través d'un sistema de refrigeració per evitar que arribe als $\mathbf{1 0 0}^{\circ} \mathrm{C}$ i bulla. D'aquí, la frita es condueix a sitges perquè l'aigua sobrant s'escorrega.

Figura 11 Refredament de la frita amb aigua.

En algunes instal·lacions s'utilitza un sistema de refredament per aire, en què el raig de frita fosa es fa passar entre dos corrons laminadors d'acer refractari, refrigerats per aigua al seu interior, i convertint la frita en una làmina de vidre que posteriorment es trenca en petits trossos per a ser utilitzada. D'aquí es condueix a ensacat directament.

Es important destacar que les empreses de frites i esmalts i les de pigments ceràmics han contribuït decisivament al procés d'innovació en el sector ceràmic espanyol, tant per l'esforç que han realitzat per a generar tecnologia com per transferir-la. S'han preocupat no sols d'elaborar noves frites i pigments en el moment oportú, sinó també de transferir la tecnologia de la seva aplicació a les empreses de paviment i revestiment ceràmics. 
Aquestes empreses solen dissenyar i desenvolupar models, amb les frites o pigments que produeixen, oferint a les empreses de fabricació de taulells ceràmics, les matèries primeres elaborades i la tecnologia necessàries per reproduir industrialment les peces, així com l'assistència tècnica que es necessite, en cas que aparega algun problema en tractar de fabricar-les [34]. 


\subsection{Tecnologies emergents en la fabricació d'esmalts o de sòlids inorgànics, obtingudes per optimitzar el procés industrial a nivell econòmic $i$ mediambiental i millorar les propietats dels productes.}

Els taulells ceràmics amb propietats funcionals, com ara dielèctric, piezoelèctric, piroelèctric, o ferroelèctrics són de gran interès tecnològic per la seva capacitat per a interactuar amb l'energia i amb el medi ambient que els envolta [35]. Aquestes aplicacions poden obtenir-se mitjançant l'aplicació de sistemes microelectromecànics (MEMS), que tenen aplicacions en una ampla gamma de camps i poden incorporar-se per diferents mecanismes [36].

A més, els taulells amb propietats bactericides, fosforescents, antielectrostàtiques, tèrmiques o capaços d'aprofitar l'energia solar mitjançant diferents mecanismes [37], són alguns dels nous desenvolupaments que ofereix la investigació, i que s'han incrementat durant els últims anys. Açò permet noves aplicacions, baix el punt de vista d'una reducció de l'impacte al medi ambient. Així, s'amplia el camp d'utilització de la ceràmica tradicional a zones on es requereixen unes condicions específiques que no es podien aportar fins ara, com pot ser la conductivitat, generació de calor o poder bactericida, entre d'altres [38].

Per exemple, s'han ampliat les funcions de taulells mitjançant l'aplicació d'una pel·lícula de recobriment amb $\mathbf{T i O}_{2}$ que neteja l'aire d'òxids de nitrogen [39]. A més, s'ha estudiat la capacitat fotocatalítica que presenten les fases desvitrificades dels esmalts que contenen aquest component [40], [41]. També és possible la reducció de condensació d'humitat mitjançant un revestiment d'òxid d'estany [42].

Entre els mètodes per aconseguir l'efecte antimicrobià, destaca per efectiu l'efecte oligodinàmic. La propietat oligodinámica és l'acció que certs ions metàl·lics tenen sobre els microorganismes, impedint el seu creixement (efecte bacteriostàtic), o eliminant-los (efecte bactericida). Diversos ions metàl·lics tenen aquesta propietat, inclosa la plata, titani, coure [43], mercuri, cadmi, crom, níquel, estany, plom, cobalt, zinc, ferro, manganès, arsènic, antimoni, bismut, bari i ceri [44]. També s'ha assajat la millora de les propietats bactericides amb l'addició de revestiments polímers [45] o nanoparticulats amb sepiolita.

En concret, s'ha estudiat la possibilitat d'obtenir un esmalt dopat amb $\mathbf{C e O}_{2}$ que a més de reforçar l'efecte bactericida per fotosensibilització del $\mathbf{T i O _ { 2 }}$, conservi les propietats de color blanc i alta brillantor originals, amb l'avantatge de temperatures més baixes en el processament [46]. També hi ha estudis que aconsegueixen aquest efecte mitjançant un recobriment serigràfic d'una suspensió en nanopartícules de plata [47].

Els esforços per obtenir una superfície antirelliscant en peces de gres porcellànic, s'han accentuat per aconseguir bons resultats en zones de molt de trànsit, llocs humits $\mathrm{o}$ 
superfícies que es taquen freqüentment d'oli o d'altres substàncies viscoses. Així, per assolir l'adherència suficient es necessita una certa quantitat de rugositat, molt fina en el cas de zones humides, del rang de les micròmetres. Per a contaminants més viscosos o gruixuts aquesta quantitat de microrrugositat ha de ser major si es vol protegir contra el lliscament [48].

En les dues últimes dècades, hi ha hagut un creixent interès en els materials fosforescents a causa del desenvolupament de nous pigments, o llumins, com es nomenen sovint. El resultat obtingut ha segut positiu no sols per als usos habituals, sinó que ha permès el desenvolupament d'altres usos com són la visió nocturna o l'energia

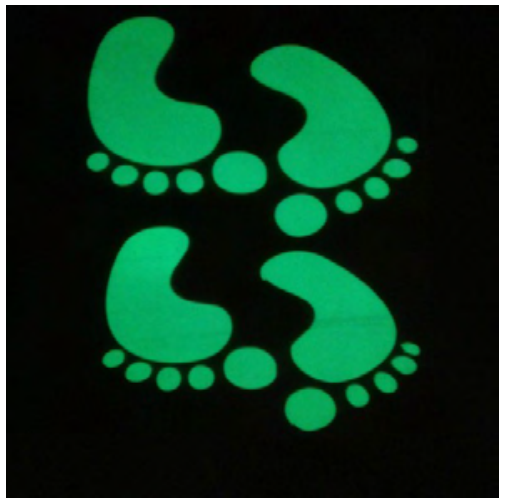
solar.

Les aplicacions actuals inclouen senyals de seguretat per als espais interiors i exteriors, sortides d'emergència $i$ senyalització per a vehicles $i$ vianants $i$ els paràmetres d'emissió que apareixen en aquestes normes s'actualitzen de forma contínua en augmentar els seus requisits [49]. A la Figura 12 es pot veure una aplicació pràctica de pigments fosforescents.

Figura 12 Aplicació d'esmalts fosforescents.

Respecte a la reflectància solar, un dels camps més desenvolupats en aquests darrers anys, per tal de protegir l'engalba i millorar la seva resistència mecànica i al desgast, es va estudiar l'aplicació d'un recobriment d'esmalt. Entre les solucions provades, es va trobar un esmalt blanc brillant que va millorar el rendiment en termes de reflectància $\mathrm{i}$ de funcionalitat del taulell solar, proporcionant un producte blanc amb una reflexió solar molt alta, un $\mathbf{0 , 8 6}$, i la mateixa resistència al sol, la pluja i les gelades que qualsevol taulell de ceràmica $[50]$.

Una de les primeres aplicacions no convencionals de taulells ceràmics va ser, fa anys, com a revestiment de transbordadors espacials. Avui en dia es poden fabricar plaques vitroceràmiques per premsat en sec de la frita molturada, amb un procés similar a la fabricació tradicional de taulells ceràmics [51]. Altres finalitats per aquest producte que es preté d'implantar en un futur són com a suports on van integrats sensors de presència per detectar el moviment o d'activació d'altres dispositius, sensors de calor per a detecció d'incendis, interruptors elèctrics, etc [52].

Es preveu que una de les eines tecnològiques que ajudarà a implantar aquestes noves funcions als suports ceràmics és la impressió digital. Hui en dia s'utilitza massivament per tal de decorar taulells ceràmics per deposició de tintes de colors, però el procés també es pot utilitzar per dipositar una gamma molt més àmplia de materials: ceràmica, metalls i polímers per a diverses aplicacions.

La impressió d'injecció de tinta té el potencial d'exercir un paper important en les millores funcionals de la ceràmica ja que ha demostrat la seva capacitat per a la deposició de pistes metàl·liques conductores, per a la fabricació de pantalles de gran 
superfície sobre la base de polímers (LEDs orgànics d'emissió de llum), i per a la impressió de transistors basats en polímers. Constitueix per tant una de les tecnologies clau per al ràpid creixement de la indústria electrònica impresa. La integració dels components electrònics $\mathrm{i}$ elèctrics impresos en els taulells ceràmics pot proporcionar importants oportunitats futures [53].

El camp de colorants ceràmics ha estat tradicionalment un dels més conservadors en la fabricació de paviments i revestiments ceràmics. L'obtenció de una reducció del cost de fabricació i la reducció de l'impacte en la salut i en el medi ambient han estat la força impulsora de la innovació en la fabricació de pigments, on els principals objectius tecnològics eren l'obtenció de rutes de síntesi ràpida i la minimització de la utilització de components $\mathrm{i}$ additius perillosos.

L'aparició i desenvolupament de la decoració digital està obligant a l'actualització contínua del sector per adaptar-se al desenvolupament tecnològic de les noves aplicacions de pigments com a tintes colorants. Amb aquest objectiu, s'estudien i revisen les propietats de les suspensions: condicions reològiques, tensió superficial, potencial zeta, la sedimentació, la cinètica de penetració, la mida de partícula, el control de les propietats elèctriques i magnètiques, l'estabilitat en mitjans orgànics, i la millora de la força colorant [54].

La deposició electroforètica (EPD) és un mètode electroquímic que implica dos passos. En el primer pas s'aplica un camp elèctric entre dos elèctrodes i les partícules carregades suspeses en un líquid adequat es mouen cap a l'elèctrode de càrrega oposada (electroforesi). A la segona etapa les partícules s'acumulen en l'elèctrode de deposició i creen una pel·lícula relativament compacta i homogènia (deposició).

Per tal d'aplicar eficaçment aquesta tècnica per processar materials, és essencial produir una suspensió estable que continga partícules carregades lliures per moures quan s'aplica un camp elèctric. Per tant, EPD es pot aplicar a qualsevol sòlid preparat com una pols fina o com una suspensió col·loïdal, incloent metalls, polímers, ceràmiques $\mathrm{i}$ vidres. Després de la deposició, normalment es necessita una etapa de tractament tèrmic per densificar encara més el dipòsit i per eliminar la porositat [55].

La tendència actual consisteix a augmentar la quantitat de material que es pot dipositar, així com la mida de partícula, cosa que pot simplificar el tractament previ dels esmalts que s'apliquen [56]. Aquest punt suposa la pèrdua de definició a favor de l'augment de capa dipositada. Altres punts investigats són el desenvolupament de nous pigments, que augmenten l'espectre colorimètric que es pot obtenir i l'adaptació del sistema per a aplicar amb productes no porosos, com són les superfícies vitrificades sobre les que s'apliquen les decoracions anomenades de tercer foc [57].

Per altra banda, la innovació que suposa l'aplicació de tècniques digitals a la fabricació de productes convencionals, impulsa noves possibilitats per aconseguir productes innovadors [58]. D'aquesta manera, es treballa també per augmentar el control sobre els mecanismes de síntesi i les propietats del producte final [59]. Així es pretén millorar la 
funcionalitat dels taulells amb l'obtenció de una superfície millorada, estèticament i tècnica [60].

Hi ha estudis per a fer síntesis per deposició amb sol-gel de pigments a nivell industrial [61]. Tenint en compte la possibilitat de fer producció fotovoltaica a gran volum, el desenvolupament de tècniques de deposició de baix cost per aquest material ha atret l'interès de diversos grups de recerca. Així, s'han documentat diverses rutes de deposició lliure de buit: esprai piròlisi, la deposició fotoquímica, sol-gel [62], i electrodeposició [63].

El que es necessita ara són nous desenvolupaments que permetin reduccions en els recursos (materials, aigua i energia) que s'utilitzen en la industria. Cal un canvi per permetre competir en el valor afegit. Aquest canvi permetria a la indústria que evolucioni d'acord amb els requeriments de la societat actual i les demandes de la sostenibilitat [64].

\subsubsection{Aplicacions del LÀSER en la indústria ceràmica.}

Quant als avanços tecnològics utilitzats en la tesi que ens ocupa, cal destacar que durant els últims anys s'ha utilitzat el làser per tal de provocar l'ablació de material ceràmic obtenint decoracions i marcatge per una radiació tant intensa que es provoca la vaporització, sublimació i expulsió dels materials [65]. A la Figura 13 es poden veure peces circulant per l'interior del forn monostrat per a l'aplicació superficial del làser.

La radiació làser per a obtenir la fusió i resolidificació de superfícies de ceràmica s'ha utilitzat en el passat amb l'objectiu de segellar refractaris ceràmics porosos, per a canviar la mullabilitat de la superfície [66], [67], augmentar la resistència la desgast, modificar les propietats tribològiques [68], reparar defectes de fabricació localitzats, texturitzar superficialment o produir recobriments funcionals en ceràmica.

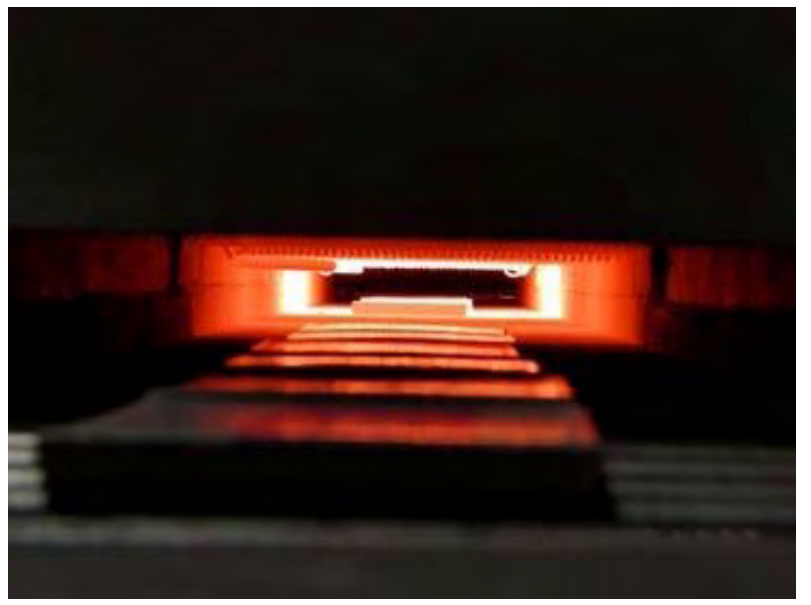

També s'han fet proves per a modificar l'arquitectura del porus i les propietats termofísiques de recobriments obtinguts per aplicació de plasma polvoritzat reforçat per la combinació de una aplicació làser in situ [69]. Altres estudis s'han centrat en la síntesi de superconductors mitjançant tècniques de deposició de làser polsat [70].

Figura 13 Forn monostrat amb làser incorporat a la zona de cocció. 
La fusió superficial amb làser permet modificar les propietats de superfície i eliminar els defectes superficials crítics que poden provocar la millora de les prestacions mecàniques del producte [69]. Així, la tecnologia làser s'ha utilitzat anteriorment per a decorar taulells ceràmics [71] i per marcar-los, fent incidir la radiació sobre un vidriat recobert de pigment [72].

La tècnica de sinterització per làser es pot classificar en tres categories pel que fa als mecanismes d'unió dels grànuls, a saber, la sinterització en estat sòlid, la sinterització amb fase líquida o de fusió parcial i la fusió de sòlids [73]. En aquest estudi s'aplicarà la radiació sobre una capa de material fos total o parcialment, amb la intenció de fondre

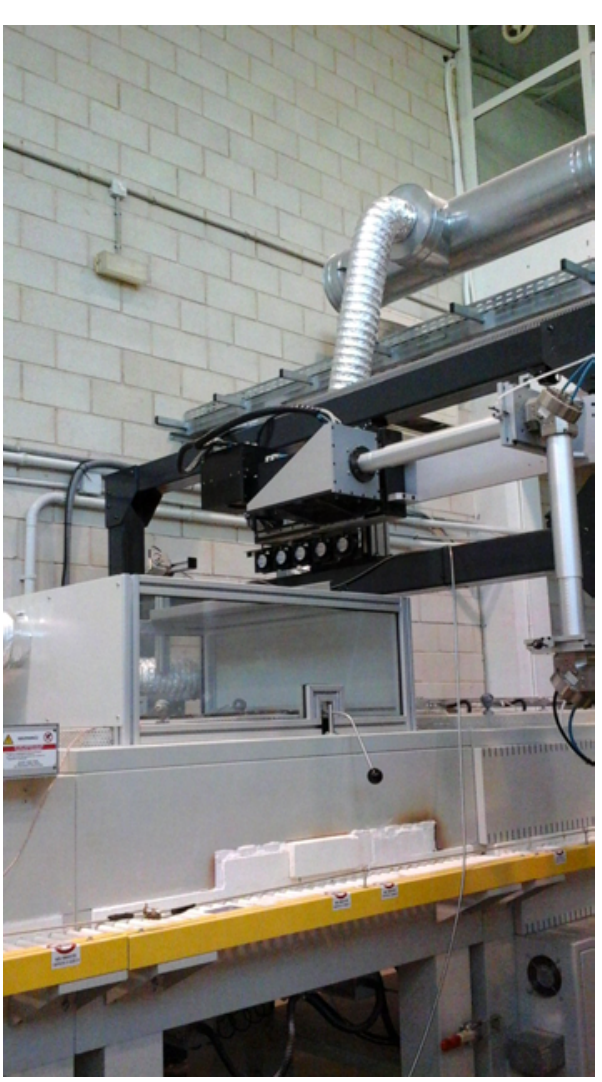
completament i estudiar la recristal·lització que s'obté.

Hi ha dues crítiques principals que es fan per a l'ús del làser a la indústria: que no permet fer produccions a nivell industrial i que no es pot conèixer exactament la temperatura d'aplicació [74]. En l'actualitat, hi ha forns de dimensions industrials, que asseguren una producció mínima, com es pot veure a la Figura 14. A més, la precisió dels làsers actuals asseguren la reproductibilitat de resultats.

L'aplicació del làser permet modificar la superfície eliminant defectes en espessors molt menuts. Per a augmentar l'amplitud d'aquest efecte es pot calfar el material abans de l'aplicació. Així, al rebre la radiació làser a una temperatura superior, l'espessor de la capa fosa i solidificada novament augmenta [69].

Figura 14 Forn monostrat de dimensions industrials amb làser incorporat a la zona de cocció.

\subsubsection{Variables de funcionament del làser.}

Es poden treballar amb diferents tipus de làser per tal d'eliminar material, obtenint un mecanitzat. Aquests tipus són principalment tres: làsers de $\mathbf{C O}_{2}$, làsers de $\mathbf{N d : Y A G ~ i ~}$ làsers tipus Excimer. Cal tenir en compte que cada tipus de làser té la seva pròpia longitud d'ona d'absorció i d'aplicacions de mecanitzat.

- Els làsers de $\mathbf{C O}_{2}$ utilitzen les molècules de gas (combinació de diòxid de carboni, nitrogen i heli) com el mitjà emissor de làser, de manera que l'excitació del diòxid de carboni s'aconsegueix mitjançant l'augment de l'energia de vibració de la molècula. Aquest làser emet llum a una longitud d'ona de 10,6 
micròmetres a la regió de l'infraroig llunyà de l'espectre electromagnètic. Els làsers de $\mathbf{C O}_{2}$ es gasten àmpliament en la indústria per aplicacions de mecanitzat làser, tractament tèrmic $\mathrm{i}$ soldat.

- D'altra banda, els làsers de Nd:YAG són làsers d'estat sòlid que utilitzen dopants (Neodinium $\left(\mathbf{N d}^{3+}\right)$ ) dispersos en una matriu cristal-lina (complex de vidre d'itri-alumini-granat (YAG) amb composició química $\mathbf{Y}_{\mathbf{3}} \mathbf{A l}_{\mathbf{5}} \mathbf{O}_{\mathbf{1 2}}$ ) per generar llum làser. L'excitació s'aconsegueix mitjançant el criptó o làmpades de flaix de xenó i es pot obtenir una longitud d'ona de sortida del 1,06 micròmetres a la regió de l'infraroig proper. Aquest làser s'utilitza en aplicacions que requereixen baixa taxa de repetició d'impulsos i energies altes de pols (fins a $\mathbf{1 0 0 J} / \mathbf{p o l s}$ ), com ara la perforació de forats i aplicacions de soldadura profundes.

- Els làsers Excimer són un tipus cada vegada més popular dels làsers de gas formats per un compost de dues espècies idèntiques que només existeixen en un estat excitat. Algunes composicions comunament utilitzades són complexos que inclouen fluorur d'argó (ArF), fluorur de criptó (KrF), fluorur de xenó $(\mathbf{X e F})$ i clorur de xenó (XeCl) amb les longituds d'ona de sortida que varien de 0,193 a 0,351 micròmetres en l'ultraviolat a espectres ultraviolada proper. Aquests compostos es poden formar mitjançant la inducció de gas noble $(\mathbf{A r}, \mathbf{K r}, \mathbf{X e})$ del compost en un estat excitat amb un feix d'electrons, una descàrrega elèctrica $\mathrm{o}$ una combinació dels dos. Els làsers Excimer s'utilitzen per a la mecanització de peces de polímers sòlid, l'eliminació de pel·lícules de metall a partir de substrats de polímers, ceràmiques del micromecanitzat i semiconductors, i marcat materials termosensibles.

Els diferents tipus de làser poden operar tant en l'ona contínua, $\mathbf{C W}$, o la manera polsada, PM (làsers nano, bec i femtosegons). En làsers de $\mathbf{C W}$, el bombeig continu del làser emet llum incessant, mentre que en un làser d'impulsos, hi ha un període d'apagada del làser entre dos làsers polsats successivament. Els làsers polsats es prefereixen per a la mecanització de la ceràmica, ja que es poden controlar millor els paràmetres.

Els fenòmens físics que tenen lloc quan el raig làser incideix sobre la superfície de ceràmica són la reflexió, l'absorció, la dispersió i la transmissió. L'absorció és la interacció de la radiació electromagnètica amb els electrons del material i depèn tant de la longitud d'ona del material com de les característiques espectrals d'absortivitat de la ceràmica tractada. La capacitat d'absorció ve també influenciada per l'orientació de la superfície de ceràmica amb respecte a la direcció del feix i arriba a un valor màxim per a angles d'incidència superiors a $80^{\circ}$. Si es parla de cavitats, múltiples reflexions del feix al llarg de la paret de la cavitat també afecten la quantitat d'energia absorbida.

En resum, les principals variables de funcionament de qualsevol làser són:

- Modus continu (CW) o polsat (PM).

- Freqüències de repetició $(\mathbf{k H z})$. 
- Potència màxima $(\mathbf{W})$.

- Velocitat de desplaçament del feix $(\mathbf{m m} / \mathbf{s})$.

A més, s'ha de tenir en compte les característiques del material, que determinen l'efecte final de l'aplicació: [75]

- Capacitat de reflexió.

- Coeficient d'absorció.

- Conductivitat tèrmica.

Els paràmetres de radiació se donen en potències i velocitats. En augmentar la potència les línies es fan més grosses i a l'augmentar la velocitat, la radiació que arriba a la superfície es va reduint, fins que pot haver un moment en què no hi ha prou radiació per a fer reacció.

\subsubsection{Especificacions del forn amb làser incorporat.}

Aquest forn amb làser incorporat s'empra per processar productes del sector ceràmic $\mathrm{i}$ del vidre. En concret s'aplica a la fabricació de productes de ceràmica plana de paviment i revestiment, de vidre i de ceràmica de tercer foc. En principi es tracta d'un forn amb una apertura a la zona de precocció, per on s'aplica la radiació làser.

Molts dels efectes estètics que s'apliquen sobre ceràmica s'obtenen a temperatures més baixes que la cocció requerida per els suports ceràmics. Són les decoracions anomenades de tercer foc o aplicades amb tècniques de bicocció. Per a obtenir aquests efectes, una forma d'aconseguir les temperatures superficials que es necessiten és l'aplicació de radiació làser, que es pot veure a la Figura 15.

Una possible solució per a eliminar tensions tèrmiques és l'escalfament de la peça en un forn, com a pas previ al processat làser. Aquest preescalfament minimitza el xoc tèrmic, anul·la el gradient originat per el feix làser i possibilita la relaxació estructural de la fase vítria per fluxe viscós.

Quan es sotmet una peça a radiació superficial, l'estrès tèrmic és funció de la mida de la mostra i de la diferència de temperatures. En incrementar la temperatura de la superfície abans de la radiació, es redueix aquesta tensió. Per tant, si s'aplica aquest tractament a la temperatura màxima, com que la superfície tractada està fosa damunt d'una superfície també fosa, les tensions d'aquests tractament s'eliminaran en solidificar.

En principi, amb la introducció del forn làser en el procés, es considera que pot permetre d'obtenir ceràmiques i vidre amb els mateixos acabats i propietats, però utilitzant temperatures sensiblement inferiors de cocció. Això suposaria un important estalvi energètic i econòmic, així com una reducció considerable de les emissions de gasos de tipus hivernacle. Els resultats que s'esperen aconseguir amb aquesta tècnica, no estan a l'abast de les tècniques que el sector utilitza en l'actualitat. 


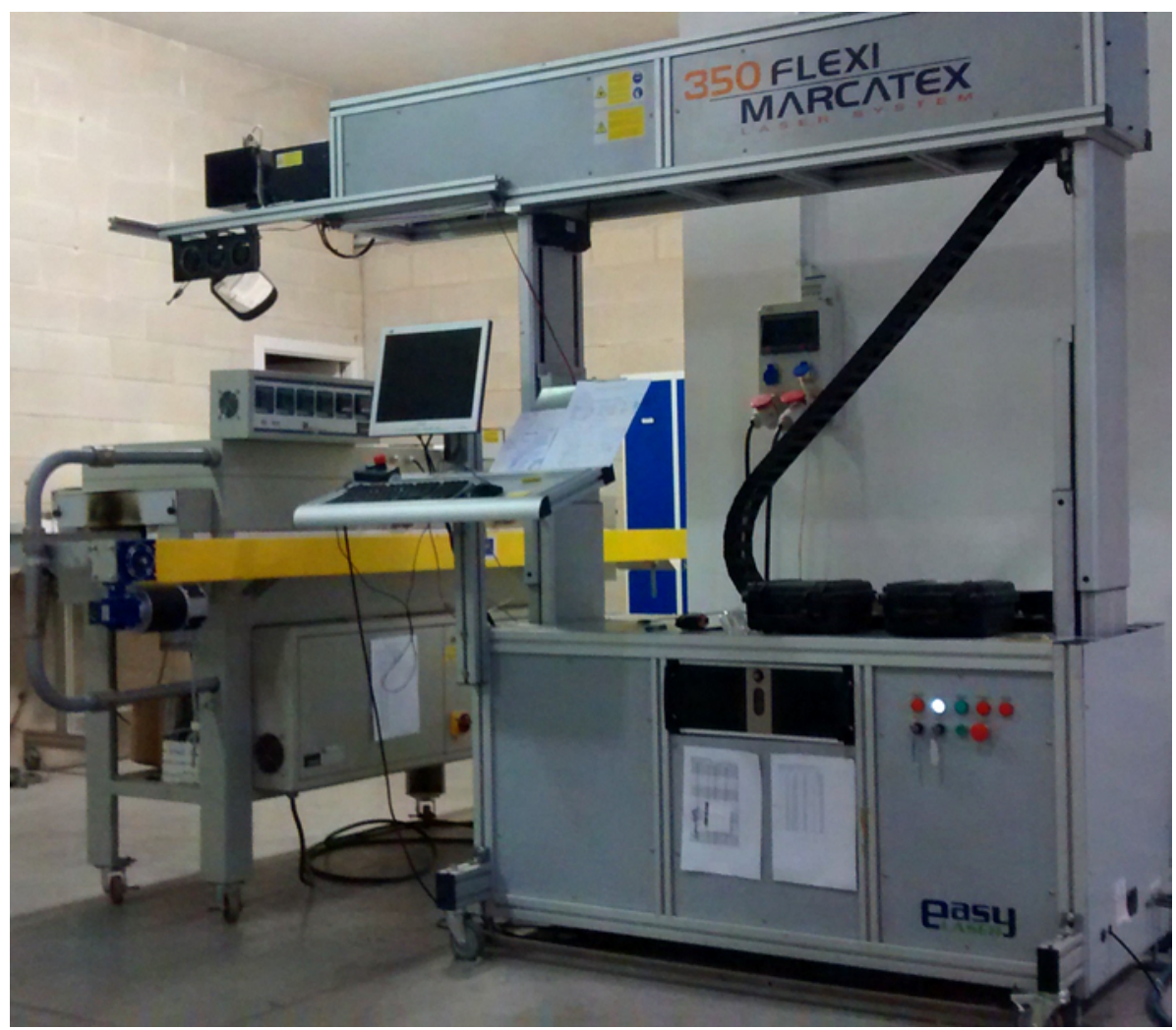

Figura 15 Làser emprat a l'estudi.

En aquest estudi es pretén generar una cristal·lització a la superfície dels esmalts crus basats en residus similar a la que s'obté a partir de material residual fritat. En estudis anteriors sobre cristal·litzacions generades amb radiació làser s'ha trobat que una de les principals dificultats durant el creixement es presenta quan l'evaporació del material fos és apreciable, cosa que pot donar lloc a variacions composicionals si es perd algun dels components preferentment.

No obstant, si la velocitat d'evaporació és lenta, es poden compensar les pèrdues de material incorporant en el precursor un excés dels components més volàtils. La velocitat d'evaporació es pot controlar, en part, ajustant el repartiment de la densitat de potència sobre la mostra o utilitzant una atmosfera estàtica en condicions de pressió [76]. 


\subsection{Valorització de residus industrials i repercussió mediambiental.}

Es poden reciclar residus introduint-los per a formar part de diferents productes ceràmics, alguns exemples són:

- Cendres volants o algeps fosforats en la aplicació de filtres d'aigua [77].

- Fangs de planta de tractament d'aigües en la fabricació de suport ceràmic [78].

- Residus de granit en forma de serradura en la fabricació de suport per a taulell [79].

- Corfes d'arròs introduïdes en composicions de mahons o inclús de pigments ceràmics $[80]$.

- Pols de pedreres produïdes durant la ruptura de roques en trituradors en ciments [81].

Hi ha diferents mètodes per a la producció de suports ceràmics amb continguts de material de rebuig, que es poden dividir en tres categories generals: la cocció, la cimentació i la geopolimerizació. En una societat basada en la recirculació, és molt important considerar el balanç total d'energia i matèria [82]. Els mètodes de cocció i cimentació (en el cas de que s'addicionen a les matèries primeres) presenten, en principi, els inconvenients d'un alt consum d'energia i de producció de $\mathbf{C O}_{2}$.

Quan el procediment per a la producció dels maons consisteix en mesclar els residus amb ciment i aigua, i utilitzar la barreja directament per la formació del producte dins de motlles, sense l'aplicació de pressió sobre ells ni cocció posterior, es redueix molt aquest consum i s'obtenen resultats acceptables en rendiment mediambiental [83].

Un altra opció és l'addició de residus orgànics en els maons abans de la cocció, en el mètode ceràmic. D'aquesta manera es pot reduir molt la temperatura de cocció, aconseguint una bona inertització, reduint el cost energètic inicial [84].

A més de residus orgànics, l'addició de residus industrials amb alts continguts en $\mathrm{CaO}$, permet una cimentació dels materials amb absència de cocció a altes temperatures, aconseguida simplement per curat [85]. És possible que hi haja d'afegir òxid de calci extra per tal d'optimitzar els resultats. En aquest cas, també s'ha estudiat la millora de les propietats del producte i l'augment de la proporció de residus introduïts si s’augmenta la pressió exercida durant la fabricació amb autoclau [86].

El mètode per a la producció de maons que continguen residus industrials a través de la geopolimerització sembla ser una bona opció també, en termes d'energia i medi ambient [87]. En aquest cas s'aconsegueix la solidificació del producte final per l'addició de compostos químics adients. 
En aquest estudi, el fet d'eliminar l'etapa del fritat, reduiria les emissions i el consum d'aigua i energia de forma important en el producte final. Per altra banda, la utilització de residus industrials en la fabricació d'esmalts s'ha estudiat amplament, obtenint inclús esmalts nanocristal·lins per a suports ceràmics [88]. S'han aconseguit bons resultats en la introducció de molts materials, com són: residus de bauxita [89], [90], granit [91] o fangs ceràmics en engalbes [92].

Cal tenir en compte que si s'utilitza un residu que continga òxids colorants, com en el cas de les cendres i escòries de les centrals tèrmiques, els esmalts preparats podran presentar pigmentació, que serà major o menor en funció de la concentració d'aquests òxids [93].

Per altra banda, al sector del taulell ceràmic s'ha fet recerca durant els últims anys per aconseguir un producte ecològic, basat en residus, que òmpliga una quota del mercat cada volta més conscienciada [94]. Dintre d'aquesta línia, és evident que la implantació de les vies de processat via seca, tant per a la fabricació del suport com per a l'aplicació de l'esmalt, suposa una reducció del consum d'aigua molt significativa [95]. En aquest cas, cal tenir en compte que les propietats dels grànuls són determinants per aconseguir bons resultats [96].

\subsubsection{Vidre reciclat.}

Tradicionalment els trossos de vidre han estat introduïts a les composicions d'esmalts. A la Figura 16 es poden veure grans de les composicions utilitzades. Es poden emprar

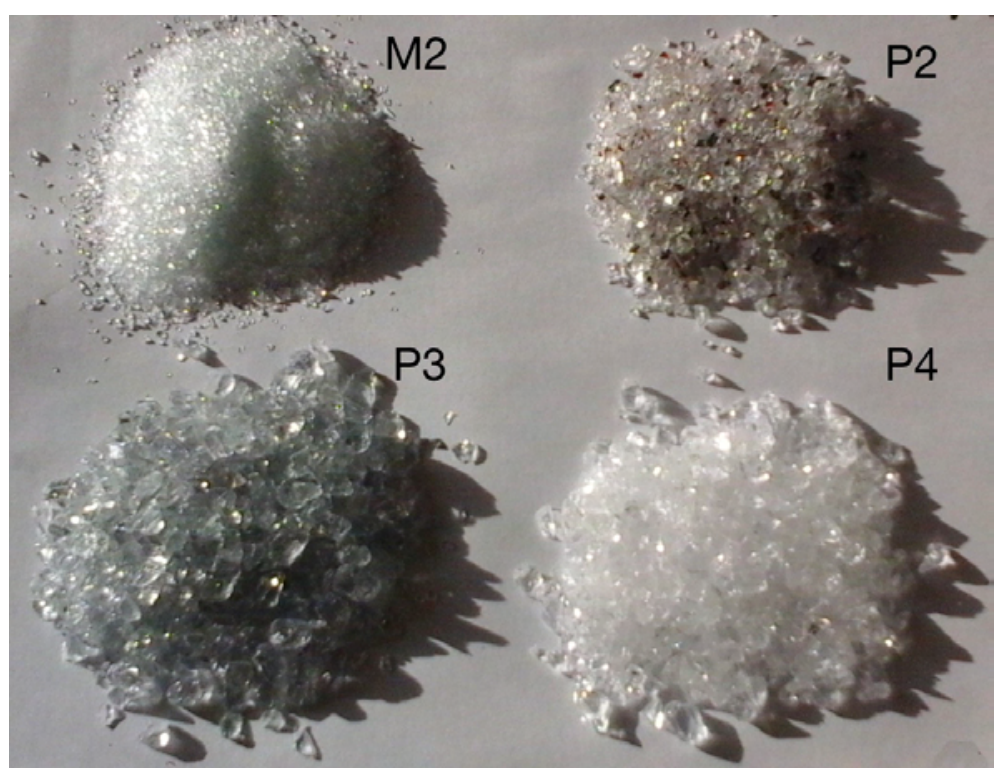

amb la finalitat d'incrementar el contingut en sílice sense tindre que pujar la temperatura de cocció. S'han utilitzat sempre per a substituir a les frites, però durant molt de temps hi havia problemes de homogeneïtat que feien inviable la seva substitució a gran escala i la seva introducció en condicions de seguretat, garantint la composició a llarg termini. 
Avui en dia, la recirculació de vidres està molt ampliada i estudiada, de manera que aquesta industria del reciclatge és capaç d'abastir la indústria ceràmica amb la seguretat i homogeneïtat necessària. Tot i que la procedència del vidre pot ser molt diversa, (vidre plànol, de botella, de llànties, de diferents parts de televisors, etc.) per assegurar la constància i abundància necessària, es duu a terme una recollida selectiva, juntament amb una classificació, diversos tractaments adients i també controls de qualitat del vidre [97].

En estudis anteriors sobre la revalorització de vidres, s'introdueixen tant en la composició de suport com en la d'engalbes [98]. En aquest treball s'introduiran a la composició del vidriat.

\subsubsection{Cendres i escòria de centrals tèrmiques.}

Per tal de reutilitzar les cendres volants generades durant la combustió de carbó per a la producció d'energia, s'ha provat el seu processat per aconseguir la conversió en zeolites, de manera que es puguen gastar com a adsorbent de baix cost per a l'eliminació de compostos orgànics, gasos de combustió i metalls [99]. A la Figura 17 es pot comprovar l'aspecte original dels residus.

Hi ha estudis al voltant de l'addició de cendres volants i cendres de fons (en endavant, escòries de central tèrmica) com additius al ciment, on s'arriben a afegir percentatges fins al $25 \%$ d'aquests residus en un ciment que acompleix normatives internacionals [100].

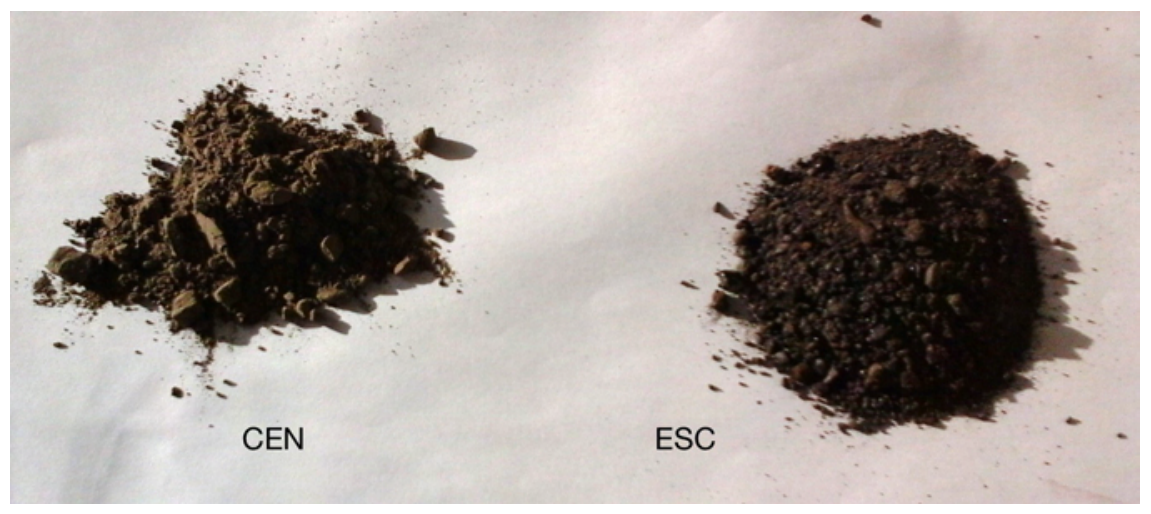

Figura 17 Cendra i escòria utilitzats.

Alguns estudis demostren que, quan s'afegeixen en percentatges baixos, les cendres volants milloren algunes propietats físiques dels maons obtinguts respecte dels que s'obtenen amb matèries primeres tradicionals [101], [102].

$\mathrm{S}$ 'ha proposat en treballs anteriors de reciclar les escòries de centrals tèrmiques de cicles combinats en forma de vidres i vidriats ceràmics per tal d'inertitzar-los, ja que són residus que es produeixen en grans quantitats, bastant homogenis, $i$ insolubles en aigua 
[103], [104]. Aquestes cendres són diferents de les que s'obtenen per el procés convencional en el tractament de combustible, també estudiats [105].

En aquesta tesi s'empren residus de cendres volàtils i escòries de la central tèrmica d'Andorra, en Terol. S'ha de tenir en compte que les cendres volants s'unflen a l'augmentar la temperatura [106]. Per a minimitzar aquest efecte negatiu durant la cocció, es treballa sempre amb material molturat.

Un altre dels inconvenients per a utilitzar aquests residus en la composició d'esmalts és l'alt contingut en ferro que presenten, que dóna lloc a una certa coloració que augmenta amb el contingut en cendres i escòries en el vidriat. 



\section{Objectius.}

L'objectiu principal d'aquesta Tesi Doctoral radica en l'estudi i desenvolupament de nous vidriats ceràmics formulats a partir de residus industrials (vidre reciclat $\mathrm{i}$ cendres de la central tèrmica d'Andorra) i sintetitzats mitjançant noves tecnologies de processat ceràmic, més respectuoses amb el medi ambient.

Per a dur a terme aquest objectiu principal, s'han proposat els següents objectius parcials:

1) Estudi documental i bibliogràfic del processat actual de vidriats ceràmics.

2) Estudi de la viabilitat dels residus industrials de diversa procedència per a la seua utilització com a matèries primeres en vidriats.

3) Valorització dels residus industrials estudiats, mitjançant la seua introducció en composicions de recobriments amb propietats determinades.

4) Preparació i caracterització físico-química de les composicions de vidriats formulades amb residus industrials.

5) Obtenció d'esmalts vitroceràmics formulats amb residus per a suports porcellànics amb bones propietats tècniques.

6) Optimització de les variables de cocció del forn monostrat amb làser per aconseguir vidriats amb bones propietats tècniques.

7) Obtenció de vidriats mitjançant un procés tecnològic basat en la ferramenta làser que permeta de prescindir de la fusió inicial per a obtenir la frita, simplificant el procés d'obtenció de revestiments vitroceràmics. 
Capítol II. Objectius 


\section{Desenvolupament experimental.}

Es destaca novament que durant aquest estudi s'han processat de forma tradicional esmalts que contenen residus de diferents indústries a la seva composició. S'ha treballat amb residus de:

1. Vidre. Provinent del reciclat de vidre domèstic.

2. Escòria. Provinents de la central tèrmica d'Andorra en Terol.

3. Cendres. Provinents de la central tèrmica d'Andorra en Terol.

S'ha plantejat de provar la introducció de residus de la indústria de producció de frites, però per problemes d'homogeneïtat d'aquests residus en gran quantitat s'ha descartat aquesta opció.

La idea general és suplir les frites en les composicions dels esmalts amb altres materials reciclats, de manera que s'obtenen dos beneficis: eliminar residus i treballar amb matèries primeres més econòmiques.

S'utilitza com a suport taulell porcellànic, que té una temperatura de cocció aproximada de $\mathbf{1 2 0 0}^{\circ} \mathbf{C}$ [107], [108]. Aquesta és, per tant, la temperatura límit de cocció.

Per aquesta part de la investigació, es treballa amb cicles industrials i en forns elèctrics, i s'ha gastat un forn amb un làser incorporat a la zona de cocció per a la segona part de l'estudi.

A partir de les dades obtingudes de les coccions a diferents cicles dels esmalts, se seleccionen les millors composicions per a realitzar un Diagrama TTT de la superfície de les peces, amb les limitacions de cicle que imposa el suport. Es fan també valoracions quantitatives de les fases formades en botons de fusió, sotmesos al mateix cicle tèrmic. Tot aquest procés ve esquematitzat a la Figura 18.

A continuació s'han triat les condicions de treball que es necessiten per a sinteritzar les composicions amb làser. Per a poder veure els efectes, cal que s'obtinguen diferents resultats en cru i fritat. Per comprovar-ho, l'elecció s'ha basat en les estructures obtingudes en els assajos de difractometria de raigs $\mathbf{X}$, i les micrografies obtingudes del microscopi de rastreig electrònic. 


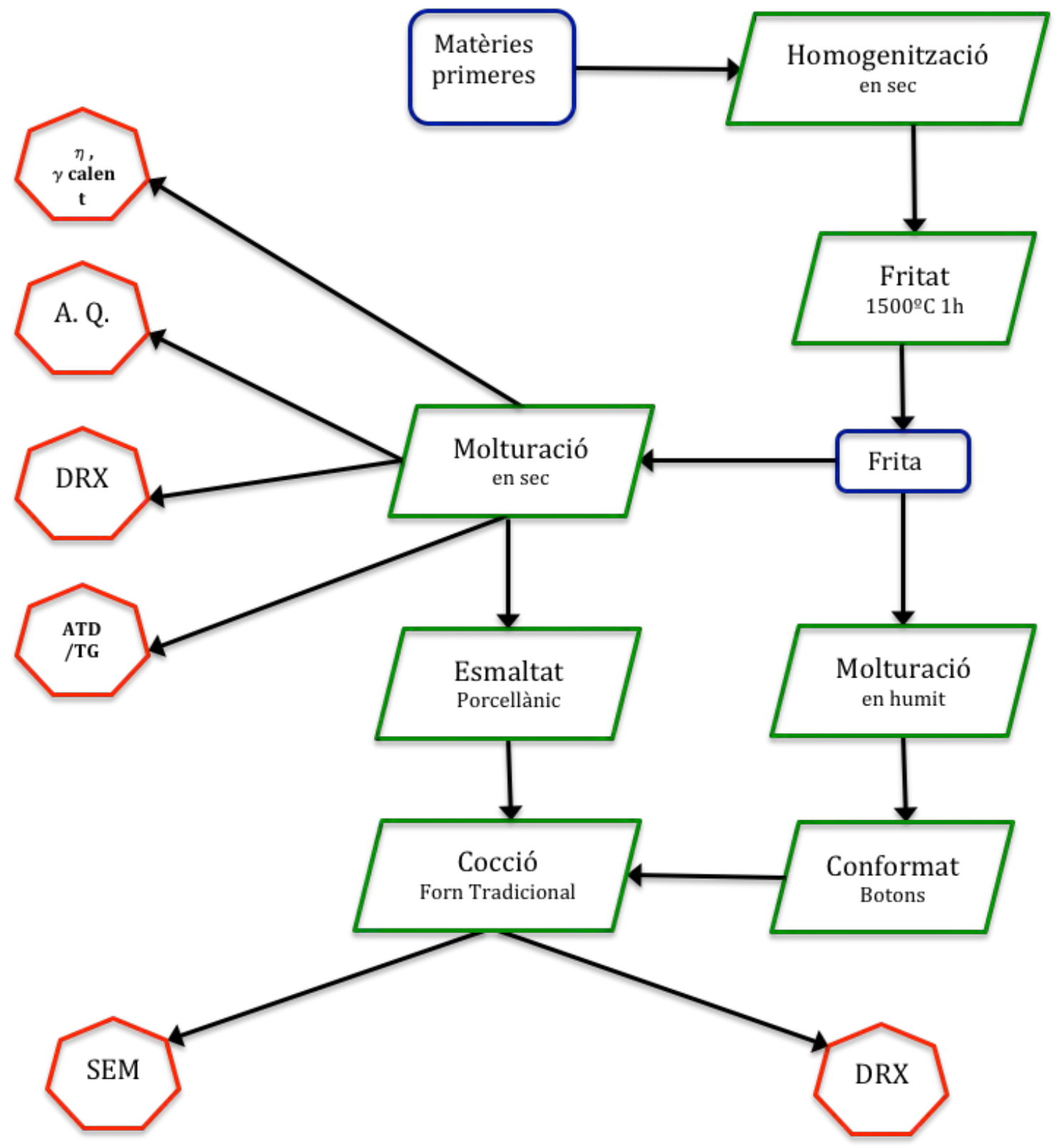

Figura 18 Esquema del procediment experimental, part 1.

Una vegada revisades les composicions, es procedeix a la segona part de la tesi, estudiant l'obtenció de vidriats a partir d'esmalts formulats amb residus, sense fritar, i amb una aplicació de radiació làser a la màxima temperatura de cocció, com es presenta esquematitzat a la Figura 19. 


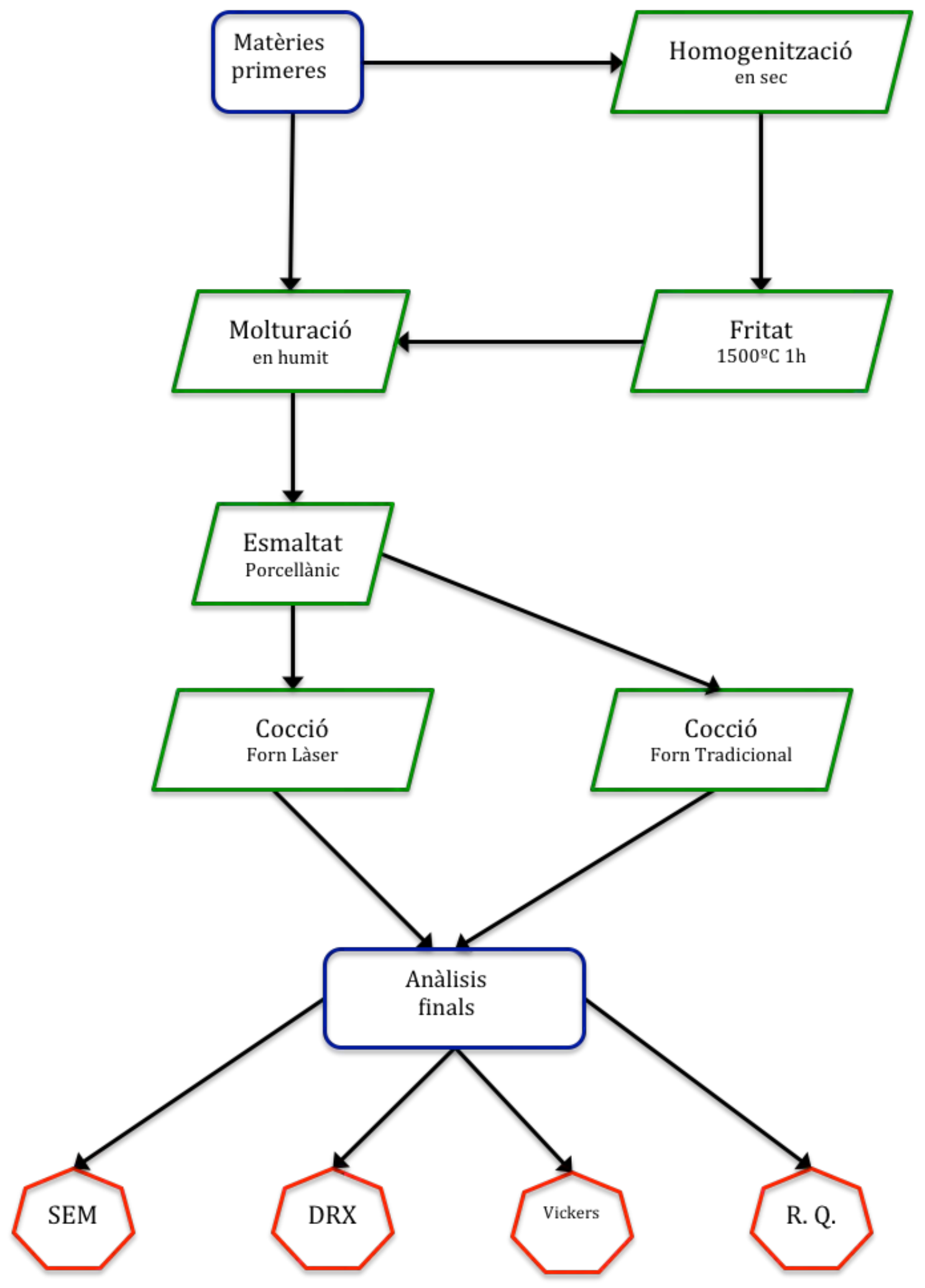

Figura 19 Esquema del procediment experimental, part 2.

Una vegada triada la dosi de radiació adient, es fa una cocció de tots els esmalts seleccionats, amb l'espessor i granulometria habitual, per a comparar les peces obtingudes amb radiació làser amb les peces obtingudes amb la cocció en forn 
tradicional. A més, es tracten peces serigrafiades i acolorides amb pigments, per veure com es modifiquen les fases formades i la definició del punt. 


\subsection{Estudi dels residus utilitzats com a matèries primeres.}

Una part dels residus utilitzats en aquest estudi provenen del sector del vidre reciclat. S'han provat 4 vidres de diferent composició, ja que provenen de parts diferents de electrodomèstics o sectors industrials. La codificació de les matèries primes emprades és:

- Els vidres reciclats s'anomenen $\mathbf{V}$ :

○ M-2: Prové les vidres de finestres o botelles.

○ P-2: Prové dels conus de televisions.

○ P-3: Prové de les pantalles de televisió.

○ P-4: Prové dels tubs per a provetes de laboratori.

D'altra banda, s'han caracteritzat també escòries i cendres volants procedents de la central tèrmica d'Andorra en Terol.

- L'escòria s'anomena ESC.

- Les cendres s'anomenen CEN.

Les mostres dels materials s'han assecat en estufa i s'han homogeneïtzat mitjançant micronitzat via seca amb un molí d'anells de carbur de tungstè-Herzog, per a obtenir una mida de gra dels residus inferior a $\mathbf{1 0 0}$ micròmetres.

També s'han utilitzat altres matèries primeres en les composicions d'esmalts, com són feldspats, tant sòdics com potàssics, carbonats de liti, bòrax, òxid de ferro i altres, per tal d'obtenir diferents composicions, com es pot veure a la Taula 1:

Taula 1 Codificació de les matèries primeres utilitzades.

\begin{tabular}{|c|c|}
\hline $\mathbf{B a C O}_{3}$ : Carbonat de Bari. & BOR: Bòrax. \\
\hline $\mathrm{CeO}_{2}$ : Òxid de ceri. & COLE: Colemanita \\
\hline CRET: Creta. & DOLO: Dolomita. \\
\hline $\mathrm{Fe}_{2} \mathrm{O}_{3}$ : Òxid fèrric. & FE: Feldspat sòdic potàssic. \\
\hline Fli: Feldspat de liti. & $\mathbf{L i C O}_{3}$ : Carbonat de liti. \\
\hline QUARS: Quars. & RÚTIL: Rútil. \\
\hline TALC: Talc. & $\mathbf{V}_{2} \mathbf{O}_{5}$ : Pentòxid de divanadi. \\
\hline $\mathbf{W O}_{3}$ : Òxid de wolframi. & ZnO: Òxid de zinc. \\
\hline
\end{tabular}




\subsection{Composicions inicials.}

Amb les matèries primeres disponibles, s'han formulat diferents esmalts, de composicions molt distintes, dels que s'obtenen propietats molt diferents.

- Per a obtenir efectes amb cristalls grans, és a dir, esmalts cristal-lins, cal composicions amb continguts molt baixos en alúmina, ja que és necessari per al desenvolupament de cristalls de mida considerable que la viscositat del material fos siga molt baixa en l'interval de temperatures de màxim creixement.

- En el cas dels esmalts que cristal-litzen aventurina, s'ha triat esmalts amb continguts baixos d'alúmina i s'ha fet una gama amb diferents proporcions d'òxid de ferro, per a comprovar el creixement de cristalls en relació a la saturació de ferro.

- S'han formulat esmalts segons els triangles dels diagrames de Ginsberg, Raschin-Tschetveritkov i Lebedeva, per a obtenir bones cristal-litzacions, que seran comparats amb els resultats experimentals.

En principi, per a estudiar esmalts amb propietats òptiques i decoratives especials, s'han triat esmalts que estan tant dins com fora d'aquest barem proposat per Ginsberg, per tal d'analitzar els diferents comportaments segons aquests paràmetres. Per tant, s'han estudiat esmalts que es troben a la zona òptima de cristal·lització segons Ginsberg, així com esmalts que estan en la zona d'alta viscositat, on es considera que la estructura és massa rígida per a obtenir un tractament adequat.

En aquest treball doctoral, s'estudien diverses composicions que, en principi, han de reflectir les diferents característiques tècniques que es poden trobar en esmalts preparats amb residus industrials, segons les fases formades durant els diferents cicles tèrmics emprats. A la Taula 2 es mostren les fórmules de càrrega $(\mathbf{F C})$ en percentatge de matèries primeres i residus de les composicions en pes de les sèries $\mathbf{A}, \mathbf{B}, \mathbf{C}$ i D: 


\begin{tabular}{|l|l|l|l|l|l|l|l|l|l|l|l|l|l|l|}
\hline F.C. (\%) & A1 & A2 & A3 & A4 & B1 & B2 & B3 & C1 & C2 & D1 & D2 & D3 & D4 & D5 \\
\hline BaCO & & & & & & & & & 5 & & & & & \\
\hline BOR & & 15 & 25 & & & & 15 & & & & 10 & & & \\
\hline CEN & & & & 15 & & 20 & 15 & & & & & & & \\
\hline COLE & & & & & & 15 & & & & & & 20 & 15 & 10 \\
\hline CRET & & & & & 20 & & & & & 10 & 10 & & & \\
\hline DOLO & & & & 10 & & & & & & & & & & \\
\hline ESC $^{5} 51$ & 30 & 25 & & & & & & & & & & 10 & \\
\hline Fe $_{2} \mathbf{O}_{3}$ & & & & & & & & & & & & & & 10 \\
\hline LiCO $_{3}$ & & & & & & & 10 & & & & & & & \\
\hline QUARS & & & & & & & & & & & & & \\
\hline RÚTIL $^{\prime}$ & & & 5 & & 5 & & & & & & & & \\
\hline V P-2 & & & & & & & & & & 90 & 80 & 80 & 75 & 80 \\
\hline V P-3 & & & & & & & & 90 & 80 & & & & & \\
\hline V P-4 & & & & & 80 & 60 & 60 & & & & & & & \\
\hline V M-2 & 49 & 55 & 50 & 70 & & & & & & & & & & \\
\hline ZnO & & & & & & & & 10 & 15 & & & & & \\
\hline
\end{tabular}

I a més, s'ha provat les composicions anomenades en les sèries $\mathbf{E}, \mathbf{F}, \mathbf{G}, \mathbf{H}, \mathbf{I}$ i $\mathbf{J}$, a la Taula 3:

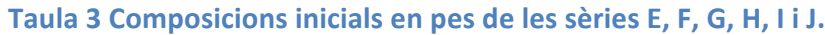

\begin{tabular}{|c|c|c|c|c|c|c|c|c|c|c|c|c|c|c|c|}
\hline F.C. en pes (\%) & E1 & E2 & F1 & F2 & F3 & F4 & G1 & G2 & H1 & $\mathbf{H} 2$ & I1 & I2 & J1 & $\mathbf{J 2}$ & $\mathbf{J 3}$ \\
\hline BOR & & 25 & & & & & & & & & & & & & \\
\hline CEN & 60 & 25 & & 5 & & & & & 10 & 5 & & & & & \\
\hline COLE & & & & & & & & & 5 & & & & & & \\
\hline CRET & & & & & & & & & 25 & 35 & & & & & \\
\hline DOLO & & & & & & & 20 & 15 & & & 25 & 20 & & & \\
\hline ESC & & & & & 10 & 40 & & 10 & & & 20 & 30 & & & \\
\hline FE & 25 & & & & 5 & 0 & & 10 & & & & 5 & & & \\
\hline Fli & & 50 & 10 & & & & & & 5 & 20 & & & & & \\
\hline $\mathrm{LiCO}_{3}$ & 10 & & 10 & & & & & & & & & & & & \\
\hline TALC & 5 & & & & & & & & & & & & & & \\
\hline V P-2 & & & 80 & 60 & 80 & 40 & & & & & & & 90 & 90 & 90 \\
\hline V P-3 & & & & 35 & & & 80 & 65 & & & & & & & \\
\hline V P-4 & & & & & & & & & 55 & 40 & & & & & \\
\hline V M-2 & & & & & 5 & 20 & & & & & 55 & 45 & & & \\
\hline $\mathrm{WO}_{3}$ & & & & & & & & & & & & & 10 & & \\
\hline $\mathrm{V}_{2} \mathrm{O}_{5}$ & & & & & & & & & & & & & & 10 & \\
\hline $\mathrm{CeO}_{2}$ & & & & & & & & & & & & & & & 10 \\
\hline
\end{tabular}

A la zona ombrejada es pot comprovar com hi ha un percentatge molt alt de material reciclat a les composicions assajades. 


\subsection{Preparació i caracterització de les composicions.}

Les composicions es friten, per tal d'estudiar la diferència amb les composicions sense fritar i estudiar realment l'avantatge, no sols econòmic, sinó també tècnic, de l'ús de residus. És més econòmic perquè resulta més barat utilitzar material reciclat que certes matèries primeres convencionals, i també perquè tenen major rang de cocció, cosa que facilita la fusió de la composició a temperatures més baixes, amb menor cost energètic. Aquestes variacions seran estudiades finalment per tal d'aconseguir propietats especials que valoritzen encara més, si cal, aquests residus industrials.

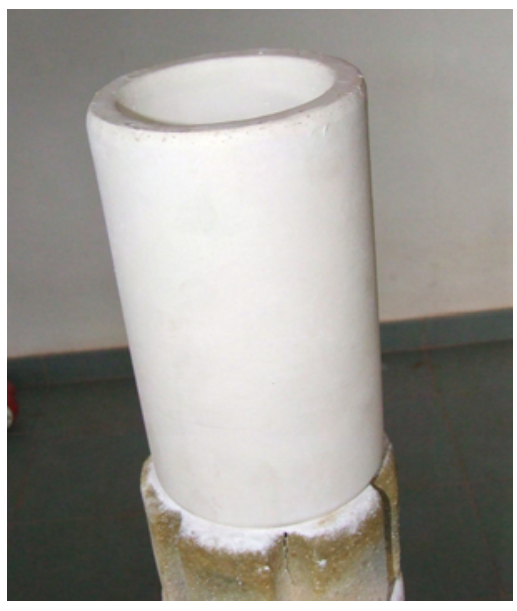

Les composicions per a fritar s'han preparat mitjançant una balança de precisió 0,01g BEL, pesant diferents partides de $300 \mathrm{~g}$, que suposa aproximadament el $\mathbf{6 0 \%}$ de la capacitat del gresol, que es mostra a la Figura 20.

Després s'han vitrificat en el forn gresolera Nanneti model FC-17, fins a una temperatura màxima de ${ }_{1500}{ }^{\circ} \mathrm{C}$ i amb un manteniment d'una hora. Per assegurar que no desvitrifiquen, s'han congelat ràpidament els líquids al buidar-se sobre un tamís en un poal d'aigua freda.

Figura 20 Gresol per a fritar.

S'ha realitzat una ATD/TG sobre un gra gros de frita sense molturar. A continuació, les mostres vítries s'han molturat via seca i s'ha separat la mostra en dues parts: una part s'ha micronitzat a una mida inferior a $\mathbf{4 5}$ micròmetres amb molí d'anells per analitzar-se per DRX, FRX i ATD/TG. L'altra part ha estat molturada via humida per a esmaltar les peces per a obtenir vidriats segons el procés ceràmic.

\subsubsection{Anàlisi química de les composicions.}

S'han realitzat anàlisis químiques per espectrometria de fluorescència de raigs $\mathbf{X}$, sobre les mostres de frites inicials. S'ha utilitzat l'equip Espectròmetre de fluorescència de raigs $\mathbf{X}$ per dispersió de longitud d'ona S4 Pioneer, Bruker (FRX).

El procediment ha consistit en assecar les mostres molturades amb anells de tungstè a $\mathbf{1 1 0}^{\circ} \mathrm{C}$ i preparar la mostra per disc de fusió amb tetraborat de liti: PPC: $\mathbf{S i}, \mathbf{1 0 5 0}^{\circ} \mathrm{C}$, $45 \mathrm{~min}$.

També s'han realitzat anàlisis del contingut en Li i B en un equip de ICP-OES. 
Amb aquestes dades, s'han situat les composicions obtingudes en els diagrames de Gingsberg, Raschin-Tschetveritkov i Lebedeva. Els resultats es presenten als annexes d'aquest document.

\subsubsection{Caracterització de les composicions amb Anàlisis tèrmiques diferencial i termogravimètrica.}

L'anàlisi tèrmica diferencial i termogravimètrica s'ha realitzat mitjançant un equip STA 503 BAHR, a $20^{\circ} \mathrm{C} / \mathrm{min}$. Amb els resultats obtinguts s'ha realitzat una valoració de $\mathbf{T}_{\mathbf{c}}$, la temperatura de màxima cristal·lització, que s'ha situat en el màxim de la corba exotèrmica.

A les composicions riques en ferro pot aparèixer $\mathbf{T}_{\mathbf{0}}$, la temperatura d'oxidació que correspon a un pic exotèrmic, però que resulta de la reacció de l'oxidació de $\mathbf{F e}^{2+}$ a $\mathrm{Fe}^{3+}$, referenciada en bibliografia sobre $\mathbf{7 8 0}^{\circ} \mathrm{C}$ [109].

\subsubsection{Caracterització mineralògica mitjançant difracció de raig $\mathrm{X}$ de la frita molturada.}

Amb el propòsit de comprovar que les matèries primes han fos totalment $i$ que no ha hagut recristal-litzacions durant la seva preparació s'han realitzats difraccions de raigs $\mathrm{X}$ de cadascuna de les frites preparades. Els resultats es presenten en els annexes al final del document.

\subsubsection{Microscòpia de calefacció.}

La frita de les composicions seleccionades s'estudia amb microscopi de calefacció Misura 3.32, fins a $\mathbf{1 3 7 3}^{\circ} \mathrm{C}$, mitjançant un cicle tèrmic d'una hora de duració. 


\subsection{Preparació de les peces.}

Per a la preparació de les peces, s'ha obtingut una barbotina d'esmalt molturada via humida en un molí planetari de 500cc de capacitat, $200 \mathrm{~g}$ de boles d'alúmina, amb una càrrega composta per $\mathbf{2 5} \mathrm{g}$ d'aigua sobre $\mathbf{7 0 g}$ de mostra, amb additius. Les mostres s'han molturat 20 minuts, mesurant la seva granulometria amb un equip de la marca Beckman Coulter model LS230, comprovant que s'obté una mida de partícula prou fina per a esmaltar. Amb aquestes condiciones, l'esmalt està sobre $\mathbf{5 0}$ segons de fluïdesa en copa Ford i una densitat aproximada de $\mathbf{1 , 7 6 g} / \mathbf{c c}$.

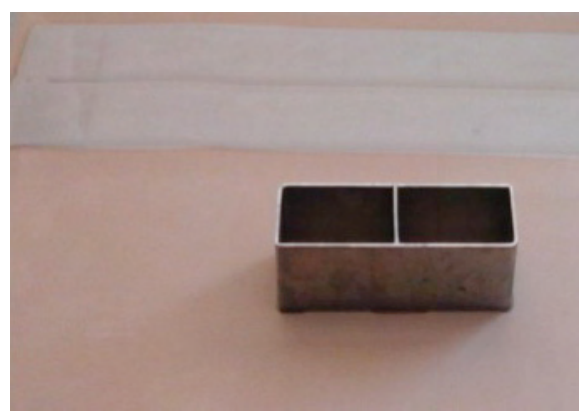

Les peces s'han esmaltat amb un patí a $\mathbf{0 , 7} \mathbf{m m}$ d'espessor, com s'aprecia a la Figura 21. Després, una vegada seques, les peces s'han sotmès a diferents cicles de cocció, sempre d'acord amb les necessitats del suport. Per tant, el que s'ha fet és modificar part del refredament per a obtenir diferents desvitrificacions.

Figura 21 Peça esmaltada amb patí de 0,7mm d'espessor.

A la Taula 4 s'indica el cicle de cocció estàndard, que es va fer en un forn NANNETTI $\mathbf{C V}$, amb ventilació per a forçar el refredament, i la gràfica corresponent es mostra a la Figura 22 :

Taula 4 Programació del cicle estàndard en forn mufla.

\begin{tabular}{|c|c|c|c|c|}
\hline INTERVAL & $\mathbf{T}_{\mathbf{i}}\left({ }^{\circ} \mathbf{C}\right)$ & $\mathbf{T}_{\mathbf{i}+\mathbf{1}}\left({ }^{\circ} \mathbf{C}\right)$ & $\mathbf{t}(\mathbf{m i n})$ & $\mathbf{V}\left({ }^{\mathbf{0}} \mathbf{C} / \mathbf{m i n}\right)$ \\
\hline $\mathbf{1}$ & $\mathbf{3 0}$ & 1000 & 30 & 32 \\
\hline 2 & 1000 & 1200 & 10 & 20 \\
\hline 3 & 1200 & 1200 & 10 & 0 \\
\hline 4 & 1200 & 500 & 23 & -30 \\
\hline 5 & 500 & 30 & 15 & -31 \\
\hline
\end{tabular}

A continuació, a la Taula 5, es presenta un esquema dels cicles aplicats per a l'estudi de la formació de fases que es formen durant el refredament de la peça. En roig estan marcades les variacions a que s'han sotmés les peces per l'obtenció de diagrames Transformació-Temperatura-Temps (TTT). 


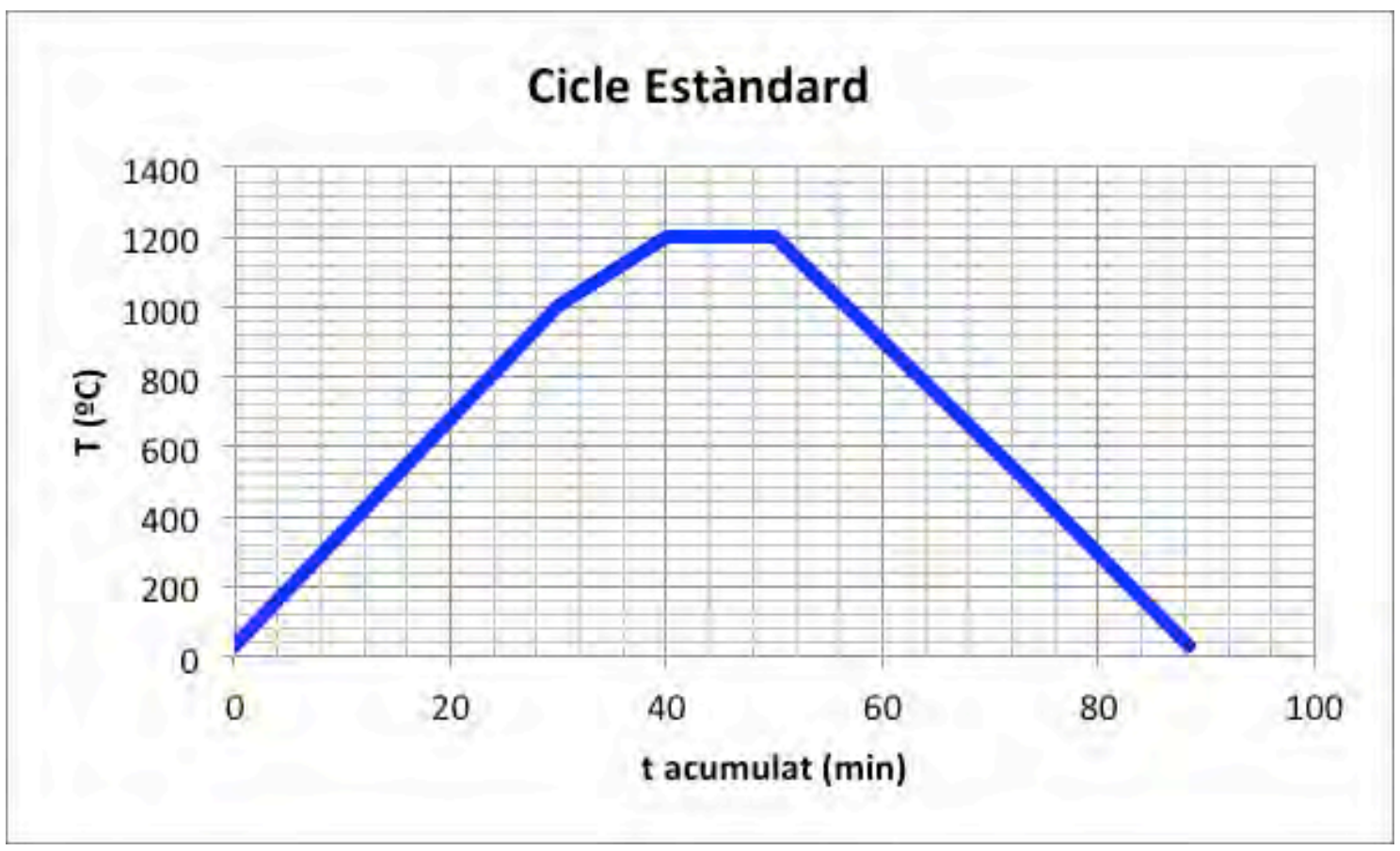

Figura 22 Gràfica del cicle estàndard.

En la taula, $\mathbf{T}_{\mathbf{p}}$ és la temperatura a la que es realitza el tram de manteniment per a la obtenció de fases en el refredament durant un temps $\mathbf{t}_{\mathbf{p}}$. La reducció de temperatura a la velocitat de refredament de $\mathbf{3 0}^{\circ} \mathbf{C} / \mathbf{m i n}$ és aproximada per a cada peça. I les variacions de $\mathbf{T}_{\mathbf{p}}$, temperatura de manteniment al final de l'interval $\mathbf{4}$, $\mathrm{i}$ els temps de permanència en aquest interval, a les que es sotmeten les peces s'indiquen a la Taula 6.

Taula 5 Cicles de cocció utilitzats en el forn Nannetti.

\begin{tabular}{|c|c|c|c|c|}
\hline INTERVAL & $\mathbf{T}_{\mathbf{i}}\left({ }^{\circ} \mathbf{C}\right)$ & $\mathbf{T}_{\mathrm{i}+1}\left({ }^{\circ} \mathrm{C}\right)$ & $\mathbf{t}(\mathbf{m i n})$ & $\mathbf{V}\left({ }^{\circ} \mathbf{C} / \mathbf{m i n}\right)$ \\
\hline 1 & 30 & 1000 & 30 & 32 \\
\hline 2 & 1000 & 1200 & 10 & 20 \\
\hline 3 & 1200 & 1200 & 10 & 0 \\
\hline 4 & 1200 & $\mathrm{~T}_{\mathrm{p}}$ & $\mathrm{x}$ & -30 \\
\hline 5 & $\mathrm{~T}_{\mathrm{p}}$ & $\mathrm{T}_{\mathrm{p}}$ & $\mathrm{t}_{\mathrm{p}}$ & $\mathbf{0}$ \\
\hline 6 & $\mathrm{~T}_{\mathrm{p}}$ & $\mathbf{5 0 0}$ & $\mathrm{y}$ & -30 \\
\hline 7 & 500 & 30 & 15 & -31 \\
\hline
\end{tabular}


Taula 6 Temperatures i temps assajats.

\begin{tabular}{|c|c|c|c|}
\hline $\mathbf{T}_{\mathbf{p}}\left({ }^{\mathbf{}} \mathbf{C}\right)$ & $\mathbf{t}_{\mathbf{p}}(\mathbf{m i n})$ & $\mathbf{t}_{\mathbf{p}}(\mathbf{m i n})$ & $\mathbf{t}_{\mathbf{p}}(\mathbf{m i n})$ \\
\hline 1200 & 60 & 30 & 10 \\
\hline 1150 & 60 & 30 & 10 \\
\hline 1100 & 60 & 30 & 10 \\
\hline 1050 & 60 & 30 & 10 \\
\hline 1000 & 60 & 30 & 10 \\
\hline 950 & 60 & 30 & 10 \\
\hline 900 & 60 & 30 & 10 \\
\hline
\end{tabular}

A la Figura 23, es presenta com a exemple el cicle aplicat a $1100^{\circ} \mathrm{C}$ durant 30 minuts de permanència:

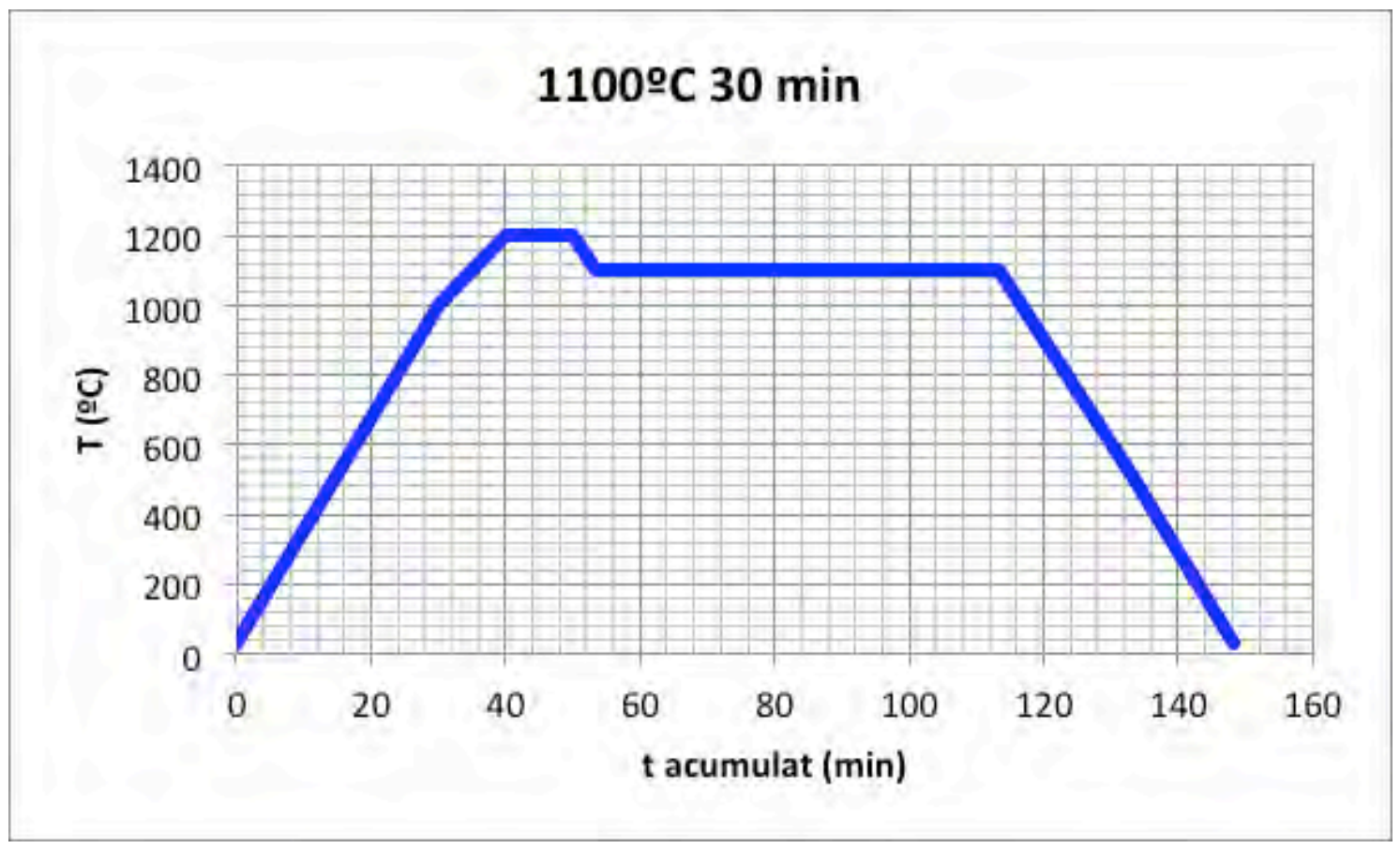

Figura 23 Cicle de cocció amb manteniment de 30 minuts a 1100 ․ . 


\subsection{Caracterització inicial dels vidriats obtinguts.}

La caracterització inicial dels vidriats obtinguts s'ha centrat en les anàlisis mineralògiques (DRX) a totes les composicions, als tres cicles tèrmics determinats. Amb l'estudi d'aquests resultats, s'han seleccionat 7 composicions de les que s'han fet anàlisis SEM i EDX i diagrama TTT.

\subsubsection{Caracterització mineralògica amb Difracció de Raigs X.}

Amb la tècnica de DRX, s'han identificat les fases presents i s'han desenvolupat els diagrames TTT de les superfícies dels esmalts més interesants des del punt de vista tècnic, calculant la proporció de fase formada a partir de la relació $\mathrm{I}_{\text {neta }} / \mathrm{I}_{\text {bruta. }} \mathrm{S}$ 'ha emprat l'equip Bruker D4-Endeavor, amb tub de $\mathbf{C u}$, monocromador de feix difractat $\mathrm{i}$ detector de centelleig.

\subsubsection{Caracterització per microscòpia de Rastreig Electrònic.}

Es realitza els assajos SEM i EDX a les peces de les composicions seleccionades a la temperatura més adient, a una hora de manteniment i al cicle estàndard. S'ha utilitzat un equip LEO 440i. Leica-Zeiss i el EDX: Oxford, INCA 250. 
3.6 Estudi de les variables de cocció amb el forn monostrat amb làser incorporat.

El primer que es fa per optimitzar les variables de cocció amb el forn nomostrat amb el làser, es preparar peces noves de porcellànic. Per açò, es tornen a elaborar les composicions triades des del principi i es torna a esmaltar. Al final tenim peces amb esmalts de composicions idèntiques fritades i sense fritar. Les peces han passat per un forn Nannetti ER 20C, a un cicle similar al cicle estàndard utilitzat en el forn mufla NANNETTI.

Les condicions de la cocció de les mostres definitives ha segut:

- Velocitat del forn de $\mathbf{1 , 5 m} / \mathbf{h}$.

- Temperatura de la zona de preescalfament $750^{\circ} \mathrm{C}$.

- Temperatura de la zona de Cocció superior $1185^{\circ} \mathrm{C}$.

- Temperatura de la zona de cocció inferior $1195^{\circ} \mathrm{C}$.

- Temperatura de la zona de refredament $\mathbf{6 2 5}^{\circ} \mathbf{C}$.

Cal destacar l'estructura del forn, que permet la radiació just abans de la zona de cocció, com s'aprecia a la Figura 24, en el punt roig. Per motius tècnics no s'ha pogut provar l'aplicació de la radiació en altres zones del cicle de cocció, la qual cosa haguera estat molt interessant.

\section{Forn monostrat amb làser}

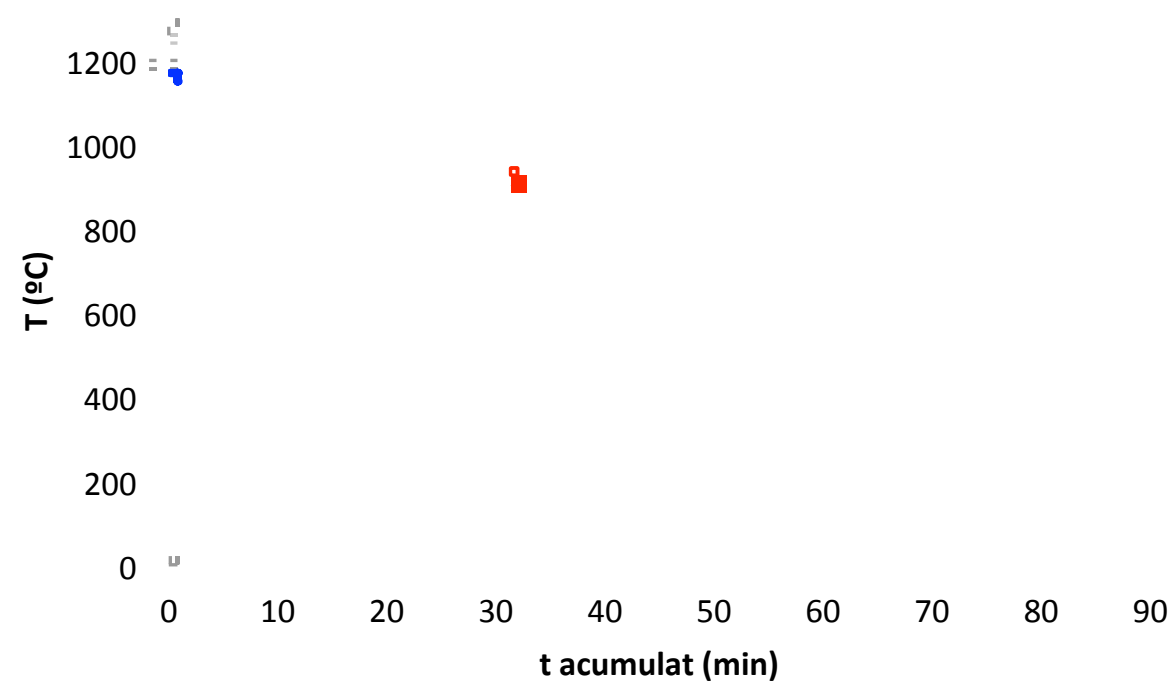

Figura 24 Cicle de cocció del forn monostrat amb làser.

Una volta s'ha acotat el cicle de cocció del forn monostrat amb làser més adient per a les composicions seleccionades, es fan una sèrie de proves per tal de trobar la quantitat 
de radiació làser per a que el material fusione sense rebullir. És a dir, que el material no sobrepasse el punt de fusió, de manera que, en principi, s'amplia el rang de cocció de les peces amb esmalts crus.

Les característiques del làser de $\mathbf{C O}_{2}$ amb el que es treballa són les següents: EasyLaser 350 Flexi Marcatex (Potencia 350W - Lent focal 800mm).

Les condicions de la radiació làser definitives s'indiquen a continuació:

- Duty cycle: $\mathbf{3 0 \%}$

- Freqüència: 20Khz.

- Ample de línia: 350mm.

- Unitats: 1320 (aprox 25m/s).

En aquestes condicions, la potència làser és de $\mathbf{2 3 8 W}$. A la Figura 25 es veu una imatge del forn, on s'observa que es tracta d'un forn monostrat per a proves. Té una obertura a la zona de cocció per on s'aplica la radiació làser.

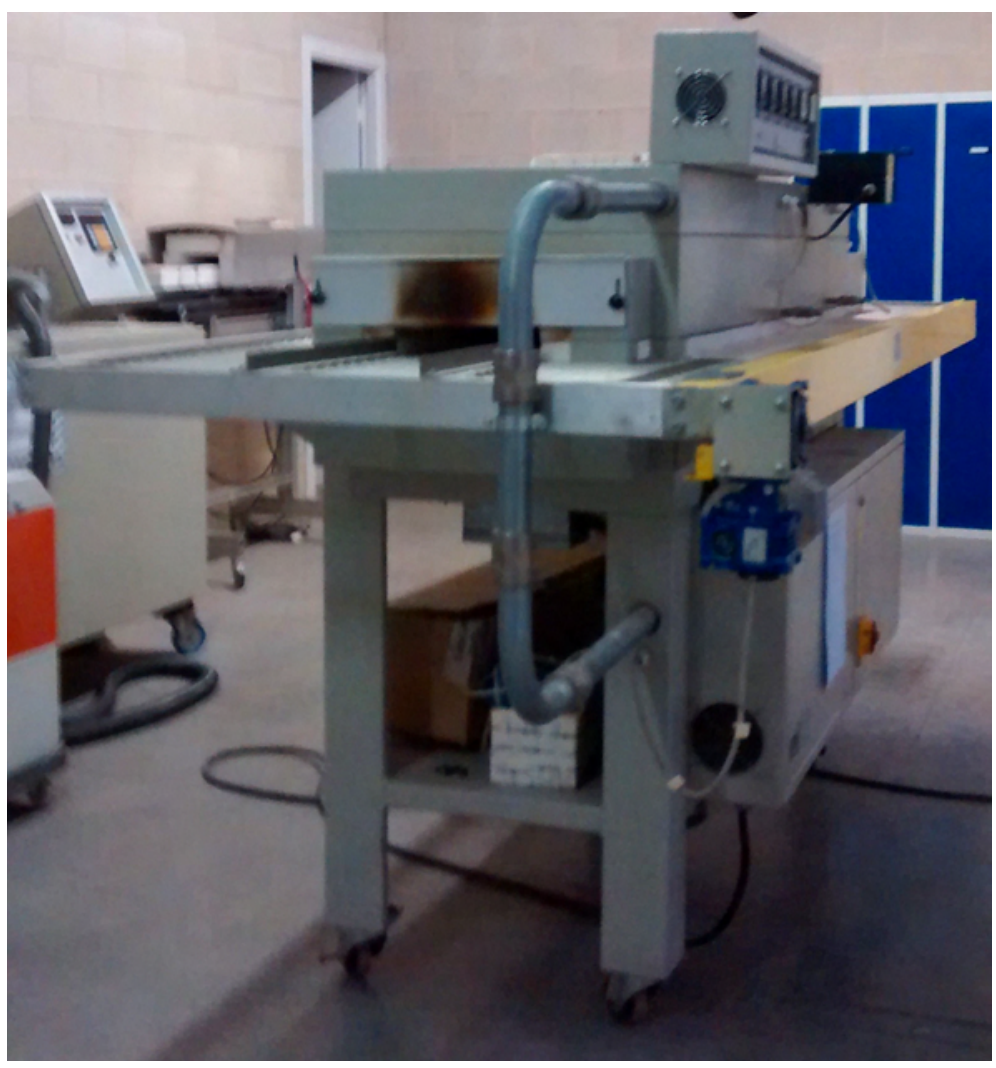

Figura 25 Forn monostrat de proves amb obertura per a làser. 


\subsection{Estudi dels vidriats obtinguts amb el forn monostrat amb làser.}

Una vegada triades les variables del procés òptimes, es preparen peces per a les coccions finals. Les peces obtingudes són analitzades amb DRX per a conèixer la seva estructura mineralògica i amb SEM, per a obtenir dades de la seva morfologia i composició.

A més de les peces esmaltades fritades i sense fritar, s'afegeixen peces amb esmalts que contenen pigment, per a veure com afecta la introducció de partícules pigmentades en les fases formades quan se li aplica el làser. També es preparen mostres de peces serigrafiades per a comparar com varia la definició del punt i les propietats superficials.

A més es fan assajos físics, de microduresa Vickers, i químics, de resistència a l'àcid clorhídric, de totes les composicions, i proves bactericides del vidriat que conté ceri a la seva composició.

\subsubsection{Assaig de microduresa Vickers.}

L'estudi de la microduresa Vickers es realitza per a comprovar que les propietats mecàniques milloren amb la formació de fases cristal·lines, tot i que aquesta millora també depèn de la fase vítria residual [110]. L'assaig es fa sobre les composicions seleccionades, a la temperatura més adequada, en un equip MITUTOYO.

\subsubsection{Resistència química.}

Aquest assaig es realitza de les composicions seleccionades, a les peces amb l'esmalt fritat, amb l'esmalt preparat amb residus cru i amb l'esmalt cru amb aplicació del làser. A tots els vidriats se'ls fa la prova de resistència química al $\mathbf{H C l}$ al $\mathbf{1 8 \%}$ durant 4 dies, segons la norma ISO10545 [111].

\subsubsection{Capacitat bactericida.}

A les composicions seleccionades que contenen ceri es fa un assaig comparatiu amb una de les peces que no en conté, per tal d'estudiar la capacitat bactericida d'aquests vidriats segons la norma ISO 22196 [112]. 


\section{Resultats i discussió.}

En primer lloc s'indiquen els resultats sobre residus industrials emprats, després sobre les frites molturades i, finalment, es presenta la caracterització dels vidriats obtinguts.

\subsection{Residus Industrials.}

Les anàlisis químiques en percentatge en pes dels residus utilitzats s'indiquen a la Taula 7:

Taula 7 Anàlisis químiques en pes dels residus utilitzats.

\begin{tabular}{|c|c|c|c|c|c|c|}
\hline Material & V P-2 & V P-3 & V P-4 & VM-2 & ESC & CEN \\
\hline $\mathrm{Na}_{2} \mathrm{O}$ & 6,5 & 8,1 & 6,8 & 13,8 & 0,0 & 0,2 \\
\hline $\mathrm{K}_{2} \mathrm{O}$ & 7,8 & 7,1 & 2,4 & 0,3 & 1,1 & 1,2 \\
\hline $\mathrm{CaO}$ & 3,0 & 0,8 & 1,0 & 9,6 & 5,2 & 5,5 \\
\hline $\mathrm{ZnO}$ & 0,1 & 0,0 & 0,0 & 0,0 & 0,0 & 0,0 \\
\hline MgO & 1,6 & 0,2 & 0,1 & 3,6 & 1,1 & 1,2 \\
\hline $\mathrm{BaO}$ & 1,9 & 8,9 & 0,0 & 0,0 & 0,0 & 0,0 \\
\hline SrO & 1,6 & 7,0 & 0,0 & 0,0 & 0,0 & 0,0 \\
\hline PbO & 21,2 & 0,0 & 0,0 & 0,0 & 0,0 & 0,0 \\
\hline $\mathrm{Al}_{2} \mathrm{O}_{3}$ & 2,8 & 2,7 & 6,7 & 1,3 & 23,8 & 26,6 \\
\hline $\mathrm{SiO}_{2}$ & 53,0 & 63,0 & 73,4 & 70,7 & 43,2 & 44,4 \\
\hline $\mathbf{B}_{2} \mathbf{O}_{3}$ & 0,0 & 0,0 & 8,4 & 0,0 & 0,0 & 0,0 \\
\hline $\mathrm{ZrO}_{2}$ & 0,3 & 1,3 & 0,0 & 0,0 & 0,0 & 0,0 \\
\hline $\mathrm{TiO}_{2}$ & 0,1 & 0,3 & 0,0 & 0,0 & 0,7 & 0,9 \\
\hline $\mathbf{P}_{\mathbf{2}} \mathbf{O}_{\mathbf{5}}$ & 0,0 & 0,0 & 0,0 & 0,0 & 0,3 & 0,4 \\
\hline $\mathrm{Fe}_{2} \mathrm{O}_{3}$ & 0,1 & 0,1 & 0,0 & 0,1 & 23,8 & 18,4 \\
\hline MnO & 0,0 & 0,0 & 0,0 & 0,0 & 0,1 & 0,1 \\
\hline $\mathrm{SO}_{3}$ & 0,0 & 0,0 & 0,0 & 0,2 & 0,2 & 0,7 \\
\hline PPC & 0,5 & 0,6 & 0,4 & 0,3 & 0,2 & 0,2 \\
\hline
\end{tabular}

Cal destacar els percentatges alts de ferro en les cendres i escòria, que condicionaran el color final dels vidriats estudiats. 


\subsection{Frita molturada.}

Les anàlisis químiques obtingudes amb FRX i amb ICP-OES de les frites molturades de les diverses composicions de vidriats ceràmics amb residus industrials, en percentatge en per, s'observen a la Taula 8: 
Taula 8 Anàlisis químiques de les frites en pols de les composicions inicials.

\begin{tabular}{|c|c|c|c|c|c|c|c|c|c|c|c|c|c|c|c|c|c|c|c|}
\hline & $\mathrm{Al}_{2} \mathrm{O}_{3}$ & $\mathrm{SiO}_{2}$ & $\mathrm{Na}_{2} \mathrm{O}$ & $\mathrm{K}_{2} \mathrm{O}$ & MgO & $\mathrm{CaO}$ & $\mathrm{TiO}_{2}$ & $\mathrm{Fe}_{2} \mathrm{O}_{3}$ & $\mathrm{ZnO}$ & $\mathrm{BaO}$ & SrO & $\mathrm{ZrO}_{2}$ & PbO & $\mathrm{WO}_{3}$ & $\mathrm{CeO}_{2}$ & $\mathrm{~V}_{2} \mathrm{O}_{5}$ & $\mathbf{L i}_{2} \mathbf{O}$ & $\mathbf{B}_{2} \mathbf{O}_{3}$ & PPC \\
\hline A1 & 13,2 & 54,7 & 6,5 & 0,8 & 2,1 & 6,6 & 0,4 & 11,0 & & & & & & & & & $<0,1$ & $<0,25$ & 0,8 \\
\hline A2 & 11,5 & 55,1 & 9,3 & 0,7 & 2,3 & 6,6 & 0,3 & 7,5 & & & & & & & & & & 5,4 & 0,1 \\
\hline A3 & 10,7 & 50,6 & 11,8 & 0,6 & 2,1 & 6,2 & 0,3 & 6,5 & & & & & & & & & & 10,3 & 0,02 \\
\hline A4 & 10,5 & 57,7 & 11,0 & 0,6 & 4,1 & 9,3 & 3,6 & 2,9 & & & & & & & & & & & 0,1 \\
\hline B1 & 7,1 & 64,7 & 5,5 & 2,1 & & 12,7 & & & & & & & & & & & $<0,1$ & 8,50 & 0,3 \\
\hline B2 & 10,4 & 56,6 & 4,3 & 1,9 & 0,4 & 6,6 & 4,1 & 1,9 & & & & & & & & & & 13 & 0,2 \\
\hline B3 & 12,1 & 55,9 & 6,8 & 1,9 & 0,0 & 2,7 & 1,0 & 2,0 & & & & & & & & & 4,6 & 12,1 & 0,2 \\
\hline C1 & 4,0 & 53,7 & 8,3 & 6,3 & 0,0 & 0,6 & 0,3 & & 9,5 & 8,7 & 6,8 & 1,3 & & & & & & & 0,2 \\
\hline $\mathrm{C} 2$ & 3,1 & 49,7 & 8,4 & 5,8 & 0,0 & 0,6 & 0,3 & & 13,2 & 10,9 & 6,0 & 1,2 & & & & & & & 0,2 \\
\hline D1 & 4,1 & 50,4 & 5,9 & 7,0 & 1,3 & 8,4 & & & & 2,2 & 1,5 & 0,3 & 17,9 & & & & & & 0,4 \\
\hline D2 & 5,6 & 47,6 & 7,4 & 6,4 & 1,2 & 8,8 & & & & 2,1 & 1,3 & 0,3 & 14,8 & & & & & 4,0 & 0,3 \\
\hline D3 & 7,3 & 45,3 & 5,3 & 5,9 & 1,4 & 7,2 & & & & 1,8 & 1,2 & 0,2 & 12,9 & & & & & 6,7 & 0,6 \\
\hline D4 & 9,1 & 46,5 & 4,7 & 5,8 & 1,4 & 6,4 & 0,2 & 1,4 & & 1,7 & 1,3 & 0,2 & 13,6 & & & & & 5,9 & 0,4 \\
\hline D5 & 6,6 & 45,8 & 5,2 & 6,2 & 1,3 & 5,1 & 0,0 & 7,0 & & 1,8 & 1,3 & 0,2 & 13,8 & & & & & 4,2 & 0,2 \\
\hline E1 & 25,2 & 50,4 & 1,6 & 3,4 & 1,7 & 3,4 & 0,6 & 8,4 & & & & & & & & & 3,5 & $<0,25$ & 1,0 \\
\hline E2 & 23,9 & 48,0 & 6,0 & 0,6 & 0,0 & 1,4 & 0,3 & 4,1 & & & & & & & & & 3,4 & 13,0 & 0,1 \\
\hline F1 & 9,2 & 53,4 & 5,2 & 6,4 & 1,1 & 2,6 & & & & 1,9 & 1,2 & 0,2 & 15,5 & & & & 2,9 & & 0,2 \\
\hline F2 & 4,7 & 56,4 & 6,7 & 7,1 & 0,9 & 2,4 & 0,2 & 0,2 & & 4,9 & 3,7 & 0,7 & 11,5 & & & & & & 0,2 \\
\hline F3 & 6,5 & 54,5 & 5,9 & 6,7 & 1,3 & 3,7 & 0,2 & 1,9 & & 1,9 & 1,3 & 0,2 & 15,5 & & & & & & 0,4 \\
\hline F4 & 12,3 & 52,8 & 5,4 & 4,3 & 1,5 & 4,3 & 0,3 & 6,7 & & 1,2 & 0,8 & 0,2 & 9,8 & & & & & & 0,6 \\
\hline G1 & 4,5 & 53,5 & 6,7 & 5,9 & 4,6 & 7,6 & 0,3 & & & 8,4 & 6,5 & 1,2 & & & & & & & 0,3 \\
\hline G2 & 7,1 & 54,4 & 6,0 & 6,3 & 3,5 & 6,4 & 0,4 & 1,4 & & 7,0 & 5,9 & 1,1 & & & & & & & 0,4 \\
\hline H1 & 11,3 & 54,3 & 3,9 & 1,7 & 0,0 & 18,5 & 0,1 & 1,1 & & & & & & & & & 0,4 & 7,9 & 0,1 \\
\hline $\mathrm{H} 2$ & 13,1 & 52,8 & 3,1 & 1,3 & & 22,8 & & 0,4 & & & & & & & & & 1,3 & 4,9 & 0,4 \\
\hline I1 & 7,9 & 54,2 & 8,2 & 0,5 & 8,1 & 15,6 & 0,2 & 4,8 & & & & & & & & & $<0,1$ & $<0,25$ & 0,1 \\
\hline I2 & 11,7 & 53,0 & 7,0 & 1,1 & 6,5 & 13,2 & 0,3 & 6,7 & & & & & & & & & $<0,1$ & $<0,25$ & 0,2 \\
\hline J1 & 4,2 & 46,9 & 5,2 & 6,1 & 1,1 & 2,7 & & & & 2,0 & 1,4 & 0,3 & 16,9 & 12,8 & & & $<0,1$ & $<0,25$ & 0,2 \\
\hline J2 & 4,1 & 46,7 & 5,9 & 6,6 & 1,1 & 2,6 & & & & 2,0 & 1,3 & 0,3 & 16,2 & 7,1 & & 5,7 & & & 0,1 \\
\hline J3 & 4,6 & 45,1 & 5,4 & 6,4 & 1,1 & 2,6 & & & & 2,0 & 1,3 & 0,3 & 16,6 & 7,0 & 6,2 & 1,1 & $<0,1$ & $<0,25$ & 0,1 \\
\hline
\end{tabular}


A partir d'aquestes anàlisis, es situen les composicions en els diagrames de Ginsberg, Lebedeva i Raschin-Tschetveritkov, presentats per sèries als annexes finals.

Com es pot comprovar als diagrames, les composicions vitroceràmiques que s'haurien de desenvolupar segons el diagrama de Ginsberg són: A3, D2, D5, I1 i I2.

Si s'observa la situació en el diagrama de Raschin-Tschetveritkov i de Lebedeva de les composicions A3, D2 i D5, es veu com A3 està a la zona viscosa del diagrama de Raschin-Tschetveritkov i en la zona II del de Lebedeva, és a dir, cristal-litzaria piroxè i magnetita, D2 està en la zona viscosa del diagrama de Raschin-Tschetveritkov i en la zona $\mathbf{V}$ del de Lebedeva, així que es considera que cristal·litzaria plagioclàsis i piroxens i D5, també a la zona viscosa del diagrama de Raschin-Tschetveritkov i situat a la zona I del diagrama de Lebedeva que s'interpreta com que cristal·litza magnetita.

Quan s'estudia la sèrie I, en principi, les dues composicions serien massa viscoses per a permetre una bona cristal-lització segons Raschin-Tschetveritkov. Segons el diagrama de Lebedeva, les dues composicions cristal litzarien plagiòclasis com a fase secundaria $i$ piroxè com a primària.

També s'analitzen les mostres de pols per DRX i es comprova que les frites les composicions dels viddriats preparades són amorfes. Aquestes gràfiques es poden consultar als annexes d'aquest treball. 


\subsection{Estudi dels vidriats.}

L'estudi dels vidriats obtinguts s'inicia amb l'anàlisi mineralògica de la superfície del vidriat cuit a 900,1000 i $1200^{\circ} \mathrm{C}$ amb una hora de permanència, per tal de seleccionar les composicions adequades per a la caracterització final i les proves amb làser.

\subsubsection{Selecció de les composicions. Anàlisis mineralògiques de Difracció de Raigs X.}

Quant als DRX d'aquests cicles, es veu com es troben fases cristal·lines als següents esmalts: A1, B1, E1, I1, I2, J1 i J3. La resta d'esmalts, presenten DRX amorfs. Per tant, s'han seleccionat aquestes composicions per a continuar amb els objectius proposats en la tesi.

En la sèrie $\mathbf{A 1}$ 1h, es poden identificar clarament dues fases: hematites $(\mathbf{H})$, en tot el rang de temperatures provades i albita (A), a les més baixes, com s'observa a la Figura 26.

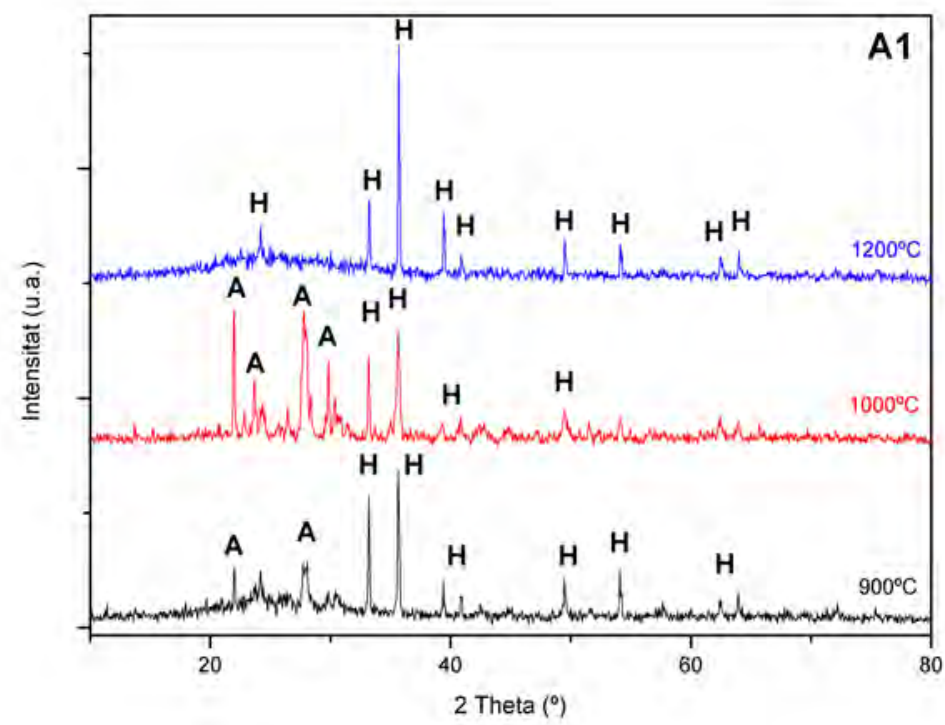

Figura 26 Difractometria de la composició A1 amb 1h de manteniment a 900, 1000 i 1200 C.

En aquesta sèrie, B1 1h, s'identifiquen clarament dues estructures minerals diferents a $\mathbf{1 0 0 0}^{\circ} \mathbf{C}$, silicat de calci $(\mathbf{S})$ i borat de sodi $(\mathbf{B})$, que pràcticament desapareixen a temperatures menors i majors, segons el difractograma mosrat a la Figura 27. 


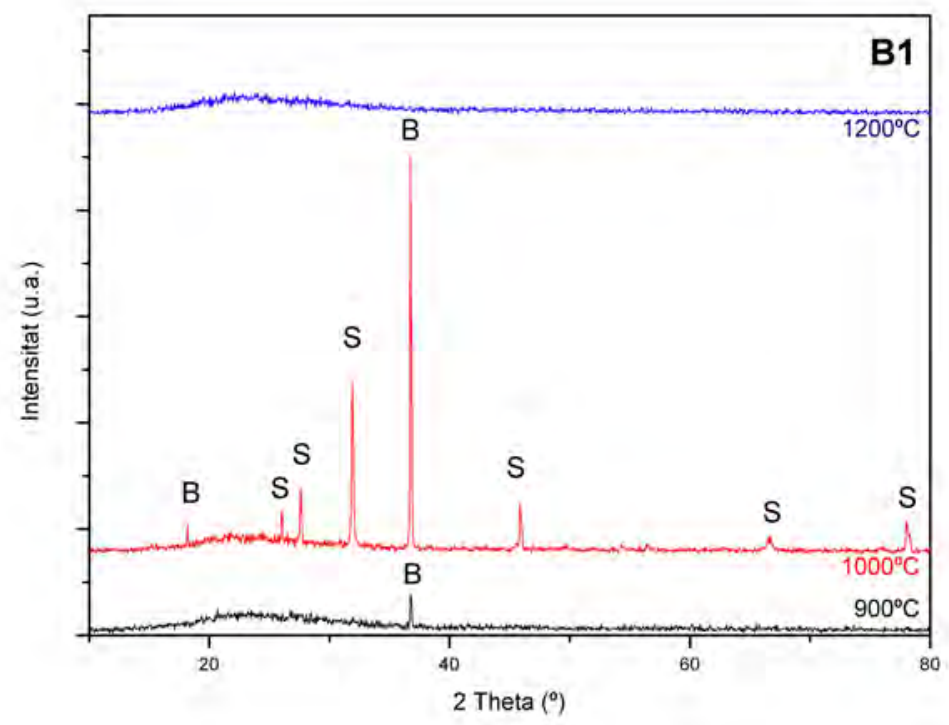

Figura 27 Difractometria de la composició B1 amb 1h de manteniment a 900, 1000 i 1200C.

De nou, es troben dues fases cristal-lines a la Figura 28, silicat de ferro (S) en tot el rang de cocció i niobofil·lita $(\mathbf{N})$, quan el manteniment es fa $900^{\circ} \mathbf{C}$, en la sèrie $\mathbf{E} 1 \mathbf{1 h}$.

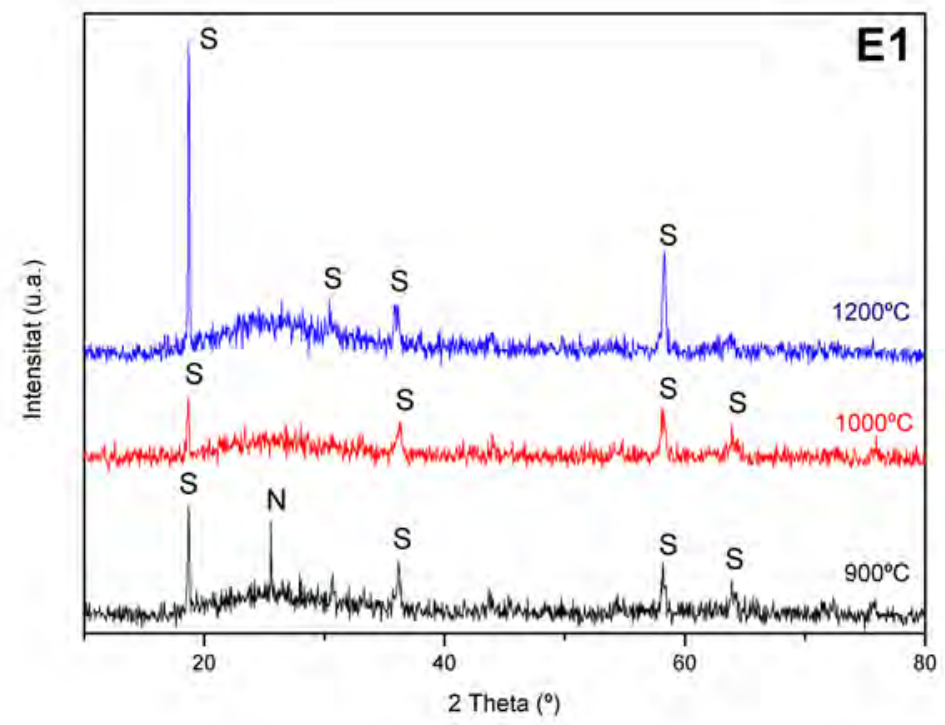

Figura 28 Difractometria de la composició E1 a 1h de manteniment a 900, 1000 i 1200C.

En el cas de la sèrie I1 1h, es troba una sola fase cristal·lina, la augita (A), mostrada a la Figura 29. S'obté idèntic resultat en la sèrie $\mathbf{I} \mathbf{2} \mathbf{1 h}$, a la Figura 30, on es pot comprovar que tots els pics queden identificats amb aquesta estructura. 


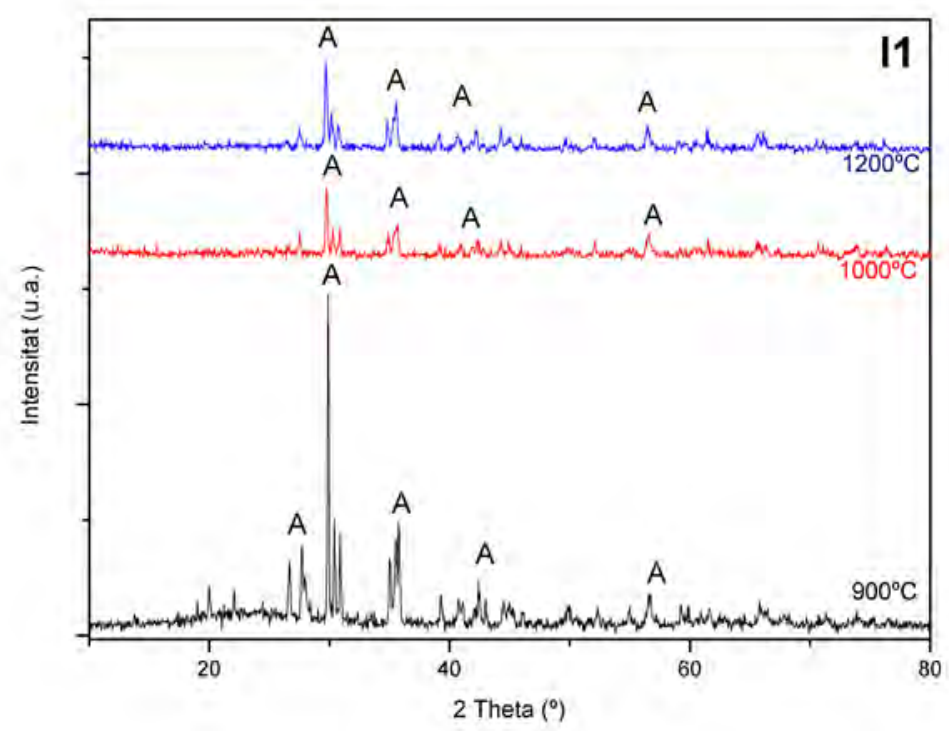

Figura 29 Difractometria de la composició I1 amb 1 h de manteniment a 900, 1000 i 1200C.

L'augita és una solució sòlida amb una composició que pot variar segons: $(\mathbf{C a}, \mathbf{N a})(\mathbf{M g}$, $\mathbf{F e}, \mathbf{A l})(\mathbf{S i}, \mathbf{A l})_{2} \mathbf{O}_{6}$, del grup dels piroxens. Aquest resultat concorda amb la predicció del diagrama de Lebedeva.

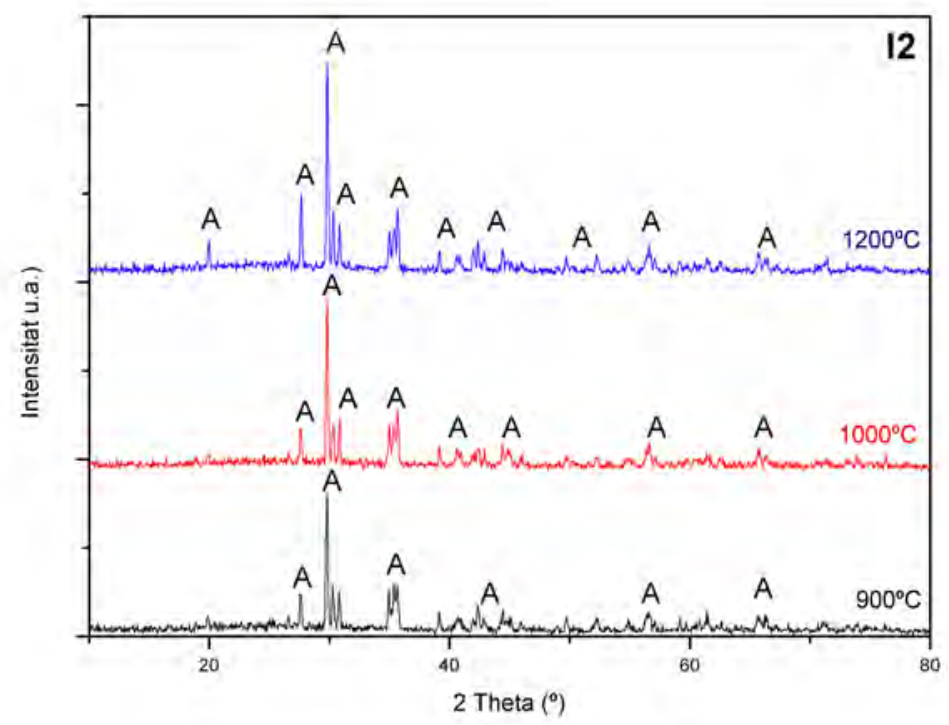

Figura 30 Difractometria de la composició I2 a 1h de manteniment a 900, 1000 i 1200C. 
Quan es revisa el diagrama que s'obté per a la sèrie $\mathbf{J 1} \mathbf{1 h}$, a la Figura 31, es torna a trobar dues estructures cristal lines, la scheelita $(\mathbf{S})$, que apareix a $900^{\circ} \mathbf{C}$ de temperatura i la hidrotungstenita $(\mathbf{H})$, una estructura hidratada que apareix en els porus i esquerdes del vidriat [113], [114].

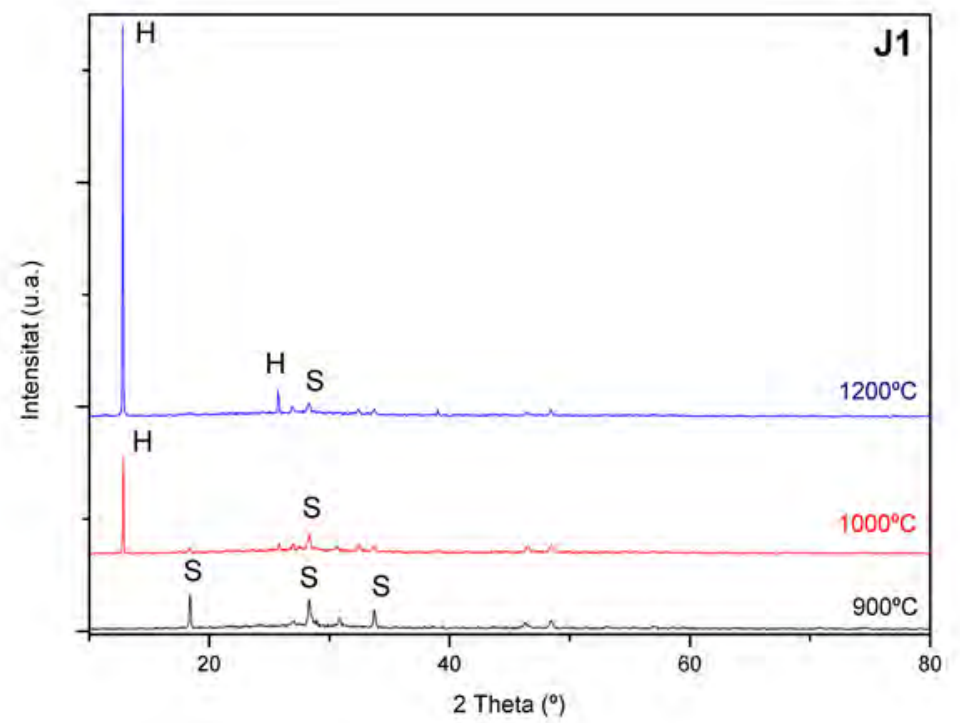

Figura 31 Difractometria de la composició J1 a 1h de manteniment a 900, 1000 i 1200C.

I la última composició, la $\mathbf{J 3}$, presenta una cristal·lització molt clara de cesiarita $(\mathbf{C})$ per a $1 \mathrm{~h}$ de manteniment en el refredament a 900,1000 i $1200^{\circ} \mathrm{C}$, com s'aprecia a la Figura 32.

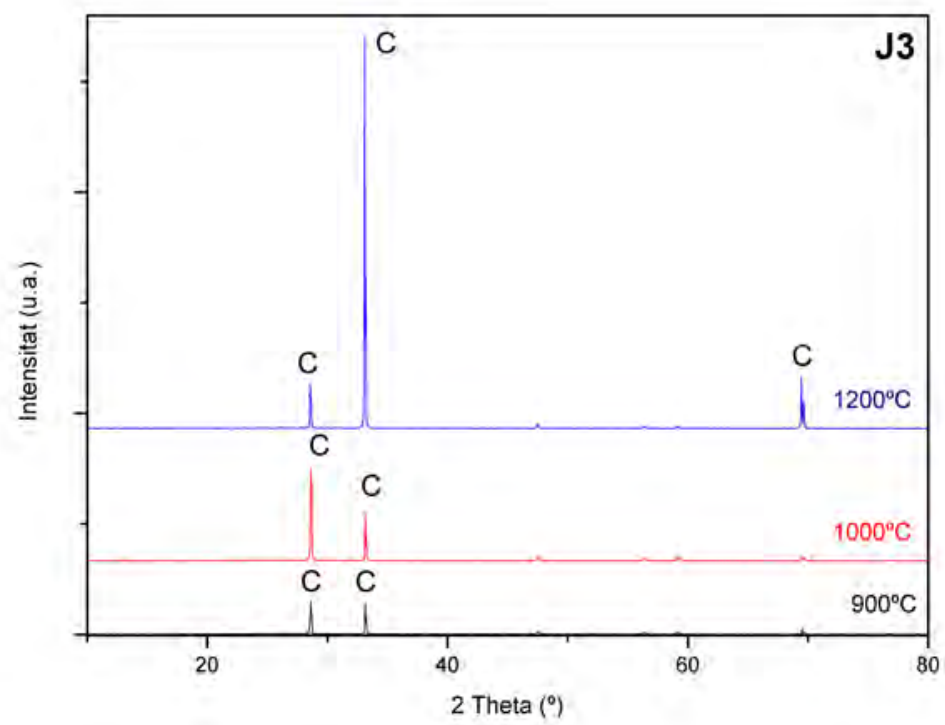

Figura 32 Difractometria de la composició J3 a 1h de manteniment a 900, 1000 i 1200C. 
Per tant, aquestes són les composicions que es caracteritzen amb el diagrama TTT de la superfície, ja que formen fases cristal·lines en el rang de cocció del suport.

Respecte de la situació de les composicions situades a la zona de cristal·lització dels triangles predictius per a vitroceràmics, sols les 2 últimes, I1 i I2, han estat seleccionades. La resta de composicions seleccionades estan a la zona viscosa del triangle de Ginsberg, rica en sílice. 


\subsubsection{Caracterització de les composicions seleccionades.}

Per a presentar la caracterització de cadascuna de les composicions seleccionades, es torna a presentar l'anàlisi química. A més, la frita de les composicions seleccionades s'estudia amb microscopi de calefacció, i es relacionen els resultats amb les anàlisis tèrmiques diferencial $\mathrm{i}$ termogravimètrica, de la frita molturada $\mathrm{i}$ d'un gra de frita (referenciat com a $\mathbf{g}$ ). A més a més, a les imatges obtingudes mitjançant microscopi de rastreig electrònic s'identifiquen les fases trobades als difractogrames, a la cocció de màxim temps de manteniment $i$ al cicle estàndard.

\subsubsection{Composició A1.}

En primer lloc, es presenta l'anàlisi química de la frita en percentatge en pes, a la Taula 9, i a continuació els resultats obtinguts amb microscopi de calefacció s'observen en la Taula 10:

Taula 9 Anàlisi química en pes de la composició A1.

\begin{tabular}{|l|l|l|l|l|l|l|l|l|l|l|l|}
\hline \multirow{2}{*}{$\mathbf{A 1}$} & $\mathrm{Al}_{2} \mathrm{O}_{3}$ & $\mathbf{S i O}_{\mathbf{2}}$ & $\mathrm{Na}_{2} \mathrm{O}$ & $\mathbf{K}_{\mathbf{2}} \mathbf{O}$ & $\mathrm{MgO}$ & $\mathbf{C a O}$ & $\mathrm{TiO}_{2}$ & $\mathbf{F e}_{2} \mathbf{O}_{3}$ & $\mathrm{Li}_{2} \mathrm{O}$ & $\mathbf{B}_{2} \mathbf{O}_{3}$ & $\mathrm{PPC}$ \\
\cline { 2 - 10 } & 13,2 & $\mathbf{5 4 , 7}$ & 6,5 & $\mathbf{0 , 8}$ & 2,1 & $\mathbf{6 , 6}$ & 0,4 & $\mathbf{1 1 , 0}$ & $<0,1$ & $<0,25$ & 0,8 \\
\hline
\end{tabular}

Taula 10 Temperatures característiques de la composició A1, mesurades amb microscopi de calefacció.

\begin{tabular}{|l|c|}
\hline & $\mathbf{A 1}\left({ }^{\circ} \mathbf{C}\right)$ \\
\hline Sinterització & 1045 \\
\hline Reblaniment & 1153 \\
\hline Mitja esfera & 1197 \\
\hline Fusió & 1252 \\
\hline
\end{tabular}

A 1'ATD/TG, presentat a la Figura 33, la frita molturada s'anomena A1 i el gra de frita A1g. Es veuen dues cristal-litzacions, una que comença a $800^{\circ} \mathrm{C}$ i que té el màxim en $\mathbf{8 3 8}^{\circ} \mathrm{C}$ i un altra que comença a $\mathbf{1 0 0 0}^{\circ} \mathrm{C}$. Si es compara aquesta corba amb la que s'obté d'una partícula grossa de frita sense molturar, podem comprovar com, en principi, la primera cristal·lització és homogènia i la segona heterogènia.

A continuació es mostren les micrografies de la composició A1 que s'han fet sobre un vidriat d'una peça cuita amb un manteniment d'una hora en el refredament a $\mathbf{1 0 0 0}^{\circ} \mathbf{C}$. Quan s'observa una secció recent, es troben porus grans, d'uns $\mathbf{4 0}$ micròmetres de diàmetre, on es pot veure unes estructures cristal·lines que creixen cap a l'interior, mostrades a la Figura 34. 


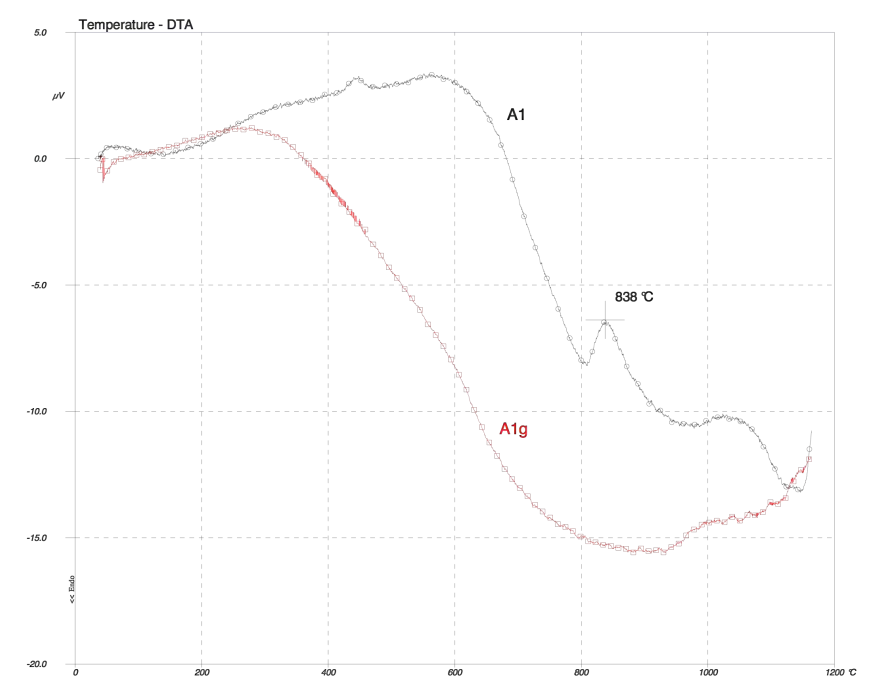

Figura 33 Anàlisis Tèrmiques Diferencial i Termogravimètrica de la composició A1.

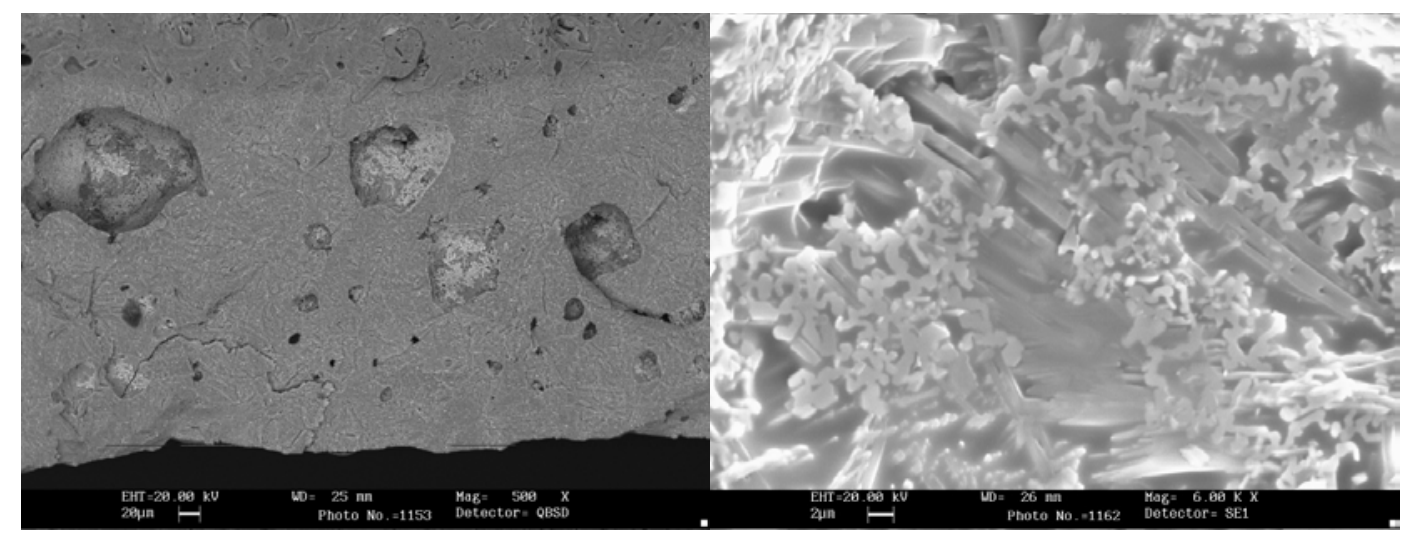

Figura 34 Micrografia de la secció de la composició A1, amb una hora de manteniment a 1000C.

Segons les anàlisis semiquantitatives del microscopi, els cristalls redons són d'hematites i la resta d'albita. Es pot comparar aquestes imatges amb les que s'obtenen a la superfície de la mateixa peça a la Figura 35. S'observen els cristalls menuts, d'hematites, però també els cristalls llargs orientats d'albita.

\section{A continuació, a la}

Taula 11 es pot veure una apreciació semiquantitativa de la composició química per EDX que es troba en la secció de la composició A1 amb $\mathbf{1 h}$ de manteniment a $\mathbf{1 0 0 0}^{\circ} \mathbf{C}$. 


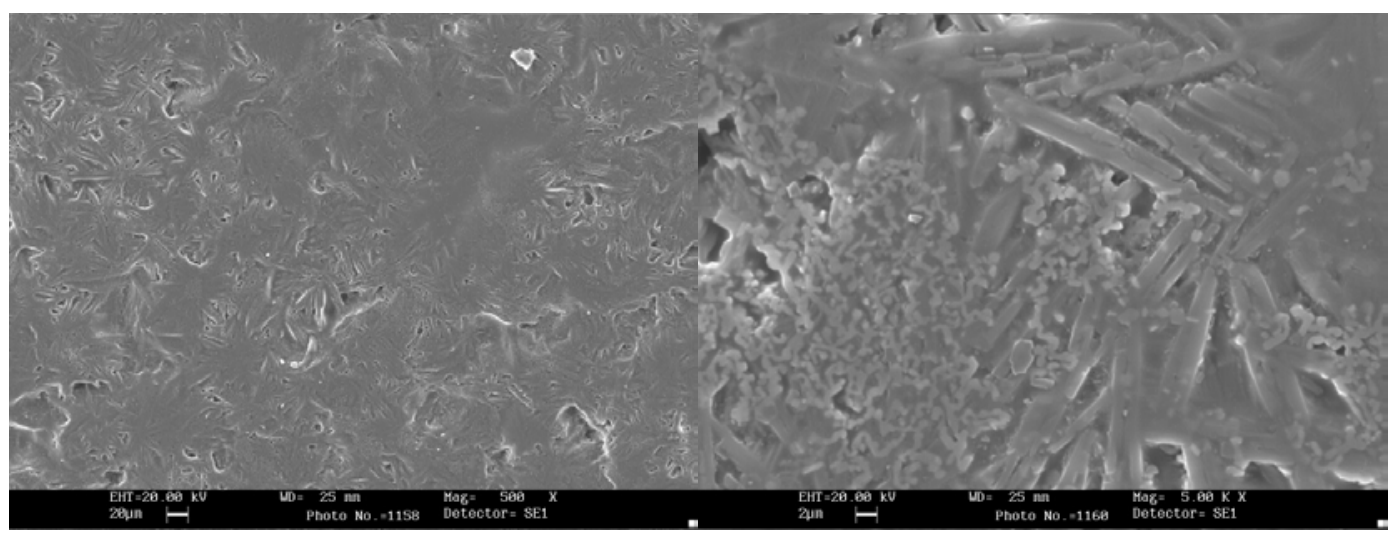

Figura 35 Micrografia de la superfície de la composició A1, amb una hora de manteniment a 1000C.

Taula 11 Microanàlisis per dispersió d'energies de raigs $X$ de la secció de la composició $A 1$ amb 1 h de manteniment a 1000 으.

\begin{tabular}{|c|c|c|}
\hline Comp (\%) & Fórmula & \\
\hline 5.07 & $\mathrm{Na}_{2} \mathrm{O}$ & \\
$\mathbf{1 2 . 1 8}$ & $\mathrm{Al}_{2} \mathbf{O}_{3}$ & \\
51.39 & $\mathrm{SiO}_{2}$ & \\
$\mathbf{1 . 5 6}$ & $\mathrm{K}_{2} \mathrm{O}$ & \\
8.59 & $\mathrm{CaO}$ & \\
$\mathbf{2 1 . 2 1}$ & $\mathbf{F e O}$ & \\
\hline
\end{tabular}

Si es comparen els resultats obtinguts en aquest cicle amb els que s'obtenen quan no hi ha manteniment per a provocar la cristal-lització, el cicle estàndard, a la Figura 36, es comprova que es troben cristalls d'hematites, menuts i redons, però no arriben a cristal·litzar les altres estructures, més llargues. En primer lloc, s'observa un tall de la peça, i a continuació, s'observa la micrografia de la superfície a la Figura 37:

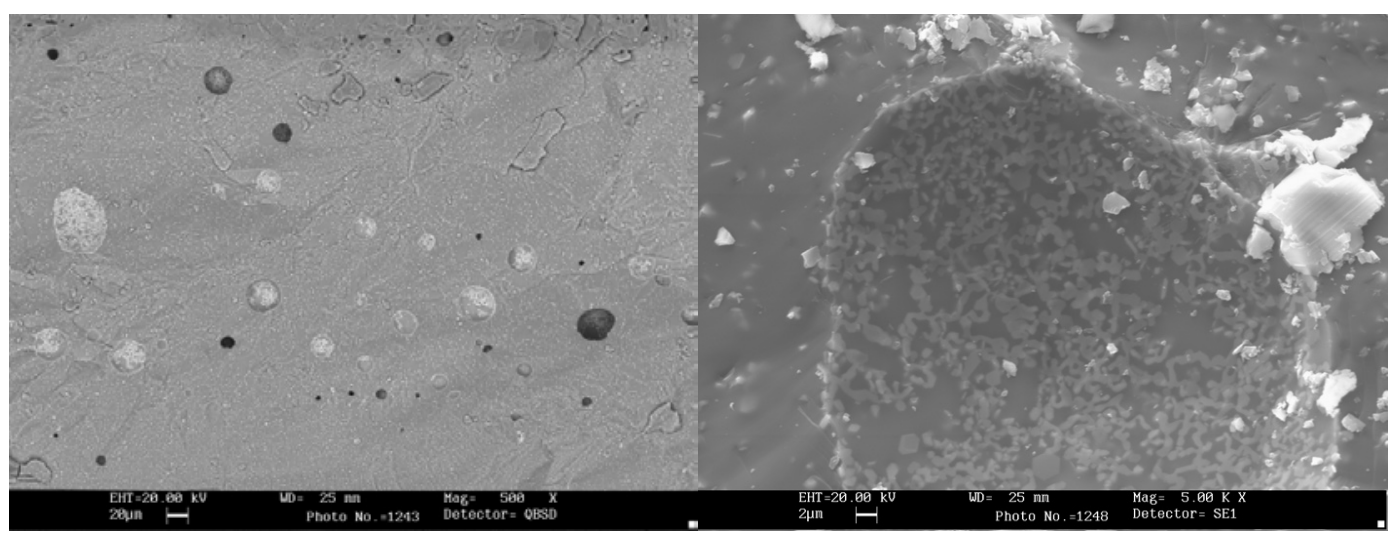

Figura 36 Micrografia de la secció de la composició A1 a cicle de cocció estàndard. 


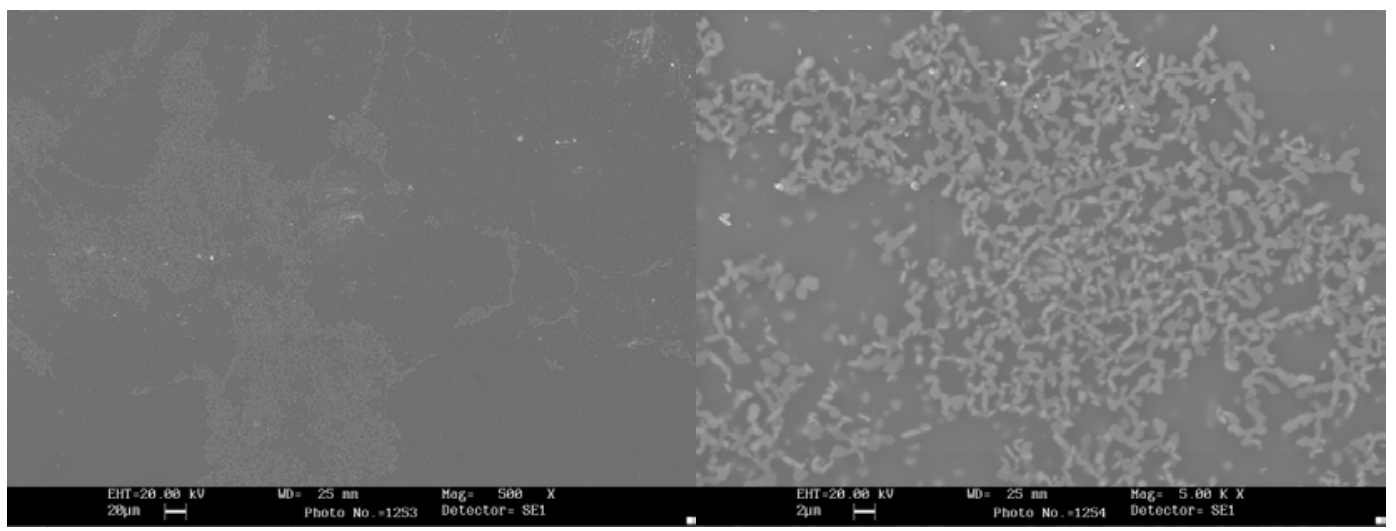

Figura 37 Micrografia de la superfície de la composició A1 al cicle de cocció estàndard.

Efectivament, segons els resultats obtinguts, no hi ha rastre dels cristalls aciculars de feldspats en la superfície. A la Taula 12 es presenten les anàlisis EDX de la composició de les fases que apareixen a la secció, de manera que els cristalls són rics en ferro i la fase vítria en sílice i alúmina.

Taula 12 Microanàlisis per dispersió d'energies de raigs $X$ de la secció de la composició $A 1$ a cicle de cocció estàndard.

\begin{tabular}{|c|c|c|c|c|c|}
\hline Comp(\%) & Fórmula & & Comp(\%) & Fórmula & \\
\hline 2.06 & $\mathrm{Al}_{2} \mathrm{O}_{3}$ & & 4.87 & $\mathrm{Na}_{2} \mathrm{O}$ & \\
$\mathbf{6 . 6 2}$ & $\mathrm{SiO}_{2}$ & $\cdots$ & $\mathbf{1 . 8 5}$ & $\mathbf{M g O}$ & $\ldots$ \\
4.33 & $\mathrm{CaO}$ & & 13.06 & $\mathrm{Al}_{2} \mathrm{O}_{3}$ & \\
$\mathbf{2 . 4 0}$ & $\mathrm{TiO}_{2}$ & $\mathbf{5 7 . 2 9}$ & $\mathrm{SiO}_{2}$ & \\
84.58 & $\mathrm{FeO}$ & & 1.39 & $\mathrm{~K}_{2} \mathrm{O}$ & \\
& & & $\mathbf{8 . 4 1}$ & $\mathbf{C a O}$ & \\
& & & 13.14 & $\mathrm{FeO}$ & \\
\hline
\end{tabular}

Aquests resultats concorden amb els que s'obté en anàlisi de DRX, que són presentats a la Figura 38, on s'aprecia que al cicle estàndard sols hi ha hematites a la superfície, mentre que al cicle de manteniment $1 \mathrm{~h}$ a $\mathbf{1 0 0 0}^{\circ} \mathbf{C}$, hi apareix també l'estructura albita a la seva superfície.

Finalment, a la Figura 39, es presenten els diagrames TTT de les fases presents a la superfície dels vidriats d'aquesta composició. Si s'observa el TTT mesurat a la superfície de les peces de la composició A1 de la fase hematites, on els punts grocs representen proporcions entre el 50 i el $\mathbf{8 0 \%}$ de fase, els verds entre el $\mathbf{8 0}$ i el $\mathbf{9 0 \%}$ de fase i els blaus per damunt del $\mathbf{9 0 \%}$, es pot deduir que les fases desenvolupades depenen en part del cicle de refredament, com es pot veure, on sembla que a $\mathbf{1 2 0 0}^{\circ} \mathrm{C}$ els cristalls d'hematites es desfan a l'augmentar el temps de manteniment a aquesta temperatura, cosa que no pareix succeir a altres temperatures. 


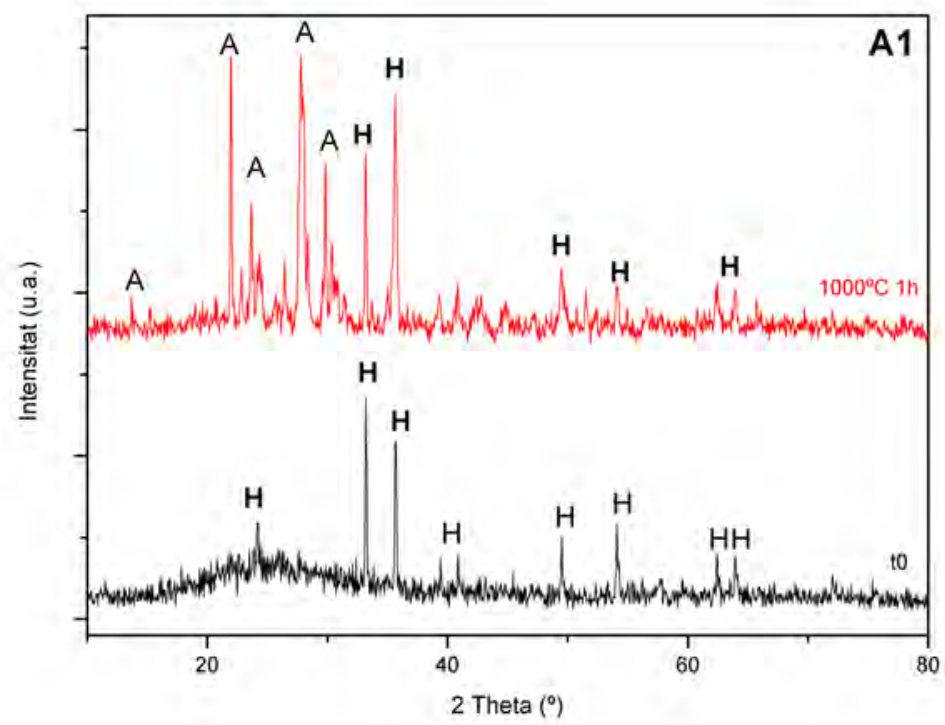

Figura 38 Difractograma de la superfície de la composició $\mathrm{A} 1 \mathrm{amb}$ 1h a 1000 ㅇ $\mathrm{i}$ a cicle de cocció estàndard.

TTT HEMATITES A1

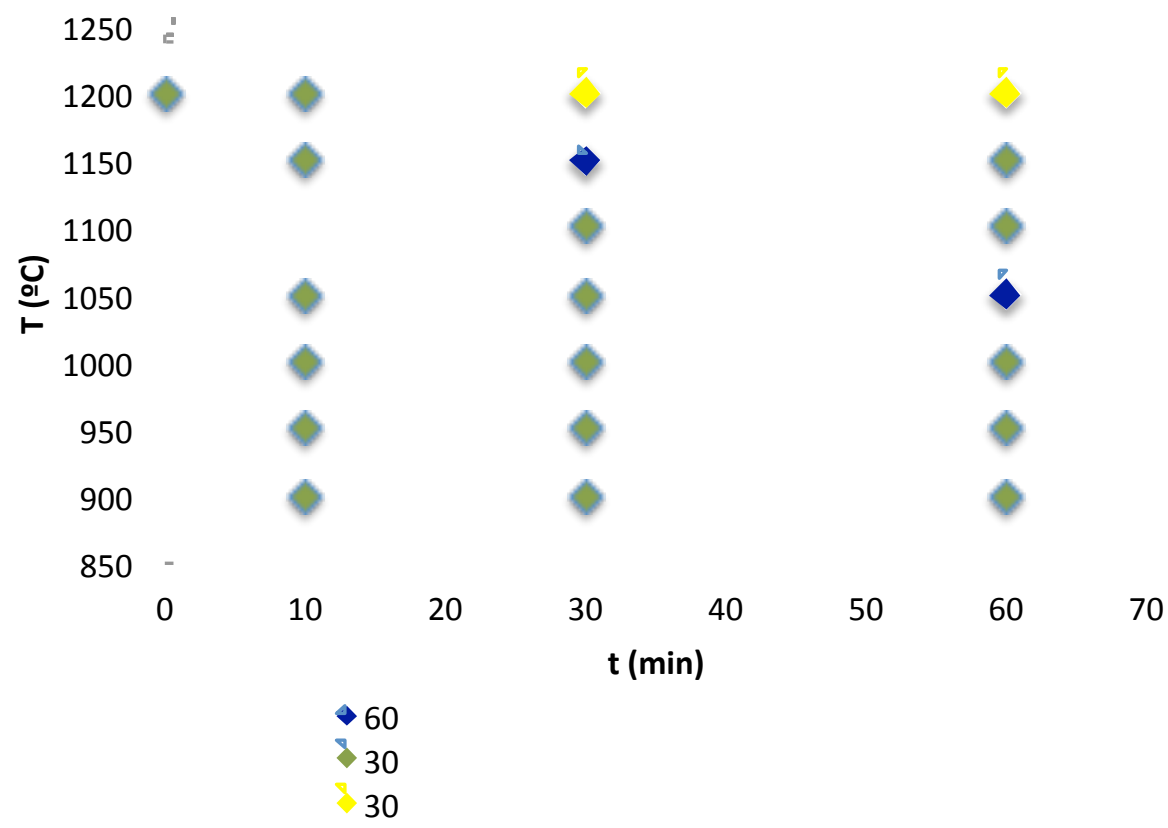

Figura 39 Diagrama Transformació-Temperatura-Temps de la fase hematites en la superfície de la composició A1.

Per altra banda, si se estudia la fase albita en la mateixa composició, es pot comprovar a la Figura 40 com és molt menys abundant a la superfície, i apareix més desenvolupada a temps llargs de manteniment en el refredament a baixes temperatures. 


\section{TTT A1 ALBITA}

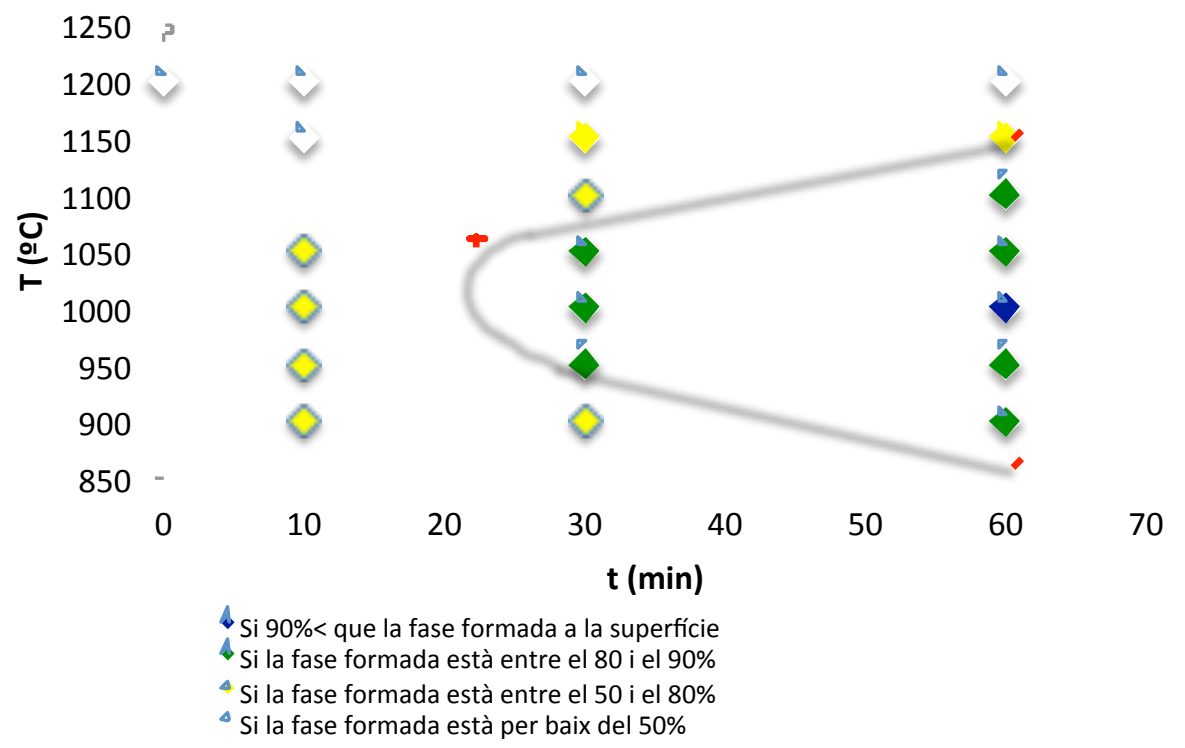

Figura 40 Diagrama Transformació-Temperatura-Temps de la fase albita en la superfície de la composició A1.

Els punts on la fase és inferior al $\mathbf{5 0 \%}$ del rati $\mathbf{I}_{\text {neta }} / \mathbf{I}_{\text {bruta }}$ es considera amorf, és a dir, que no s'ha format la fase. Són els punts buits.

Si es comparen els resultats del TTT de les superfícies amb els resultats de les anàlisis sobre botons de fusió molturats, a la Taula 13, s'aprecia com s'obtenen valors superiors però amb la mateixa tendència que a la superfície.

Taula 13 Composició mineralògica dels botons de fusió de la composició A1.

\begin{tabular}{|c|c|c|c|}
\hline Temperatura $\left({ }^{\circ} \mathbf{C}\right)$ & $\begin{array}{c}\text { Temps } \\
(\mathbf{m i n})\end{array}$ & Hematites & Albita \\
\hline 1200 & 0 & 89 & 0 \\
\hline 1200 & 10 & 90 & 0 \\
\hline 900 & 60 & 93 & 96 \\
\hline
\end{tabular}




\subsubsection{Composició B1.}

En primer lloc es revisa de nou l'anàlisi química en percentatge en pes per a destacar que és una composició silico-bòrica que presenta un contingut baix en alúmina $i$ alt en calci, a la Taula 14.

Taula 14 Anàlisi química en pes de la composició B1.

\begin{tabular}{|l|l|l|l|l|l|l|l|l|}
\hline \multirow{2}{*}{ B1 } & $\mathrm{Al}_{2} \mathrm{O}_{3}$ & $\mathrm{SiO}_{2}$ & $\mathrm{Na}_{2} \mathrm{O}$ & $\mathrm{K}_{2} \mathrm{O}$ & $\mathrm{CaO}$ & $\mathrm{Li}_{2} \mathrm{O}$ & $\mathrm{B}_{2} \mathrm{O}_{3}$ & PPC \\
\cline { 2 - 9 } & 7.1 & 64.7 & 5.5 & 2.1 & 12.7 & $<0,1$ & 8,5 & 0.3 \\
\hline
\end{tabular}

Els resultats obtinguts amb microscopi de calefacció s'observen en la Taula 15, on es comprova com la temperatura de fusió està molt per damunt de la de cocció, $1200^{\circ} \mathrm{C}$.

Taula 15 Temperatures característiques de la composició B1, mesurades amb microscopi de calefacció.

\begin{tabular}{|l|c|}
\hline & B1 $\left({ }^{\circ} \mathbf{C}\right)$ \\
\hline Sinterització & 800 \\
\hline Reblaniment & 919 \\
\hline Esfera & 1132 \\
\hline Mitja esfera & 1206 \\
\hline Fusió & 1275 \\
\hline
\end{tabular}

En l'anàlisi d'ATD/TG, a la Figura 41, s'observa com la sinterització obtinguda a $\mathbf{8 5 0}^{\circ} \mathrm{C}$, cosa que fa intuir que podria haver una cristal lització. A continuació s'observa una altra que comença a $1150^{\circ} \mathrm{C}$ i augmenta amb una pendent molt pronunciada. No s'aprecia cap de les dues a la corba del gra de frita (B1g).

Per altra banda, la microscòpia de rastreig electrònica de la Composició B1 s'ha fet sobre una peça cuita amb un manteniment en el refredament a $\mathbf{1 0 0 0}^{\circ} \mathbf{C}$, amb $\mathbf{1}$ hora de manteniment.

Si observem una secció recent, a la Figura 42, es troben porus més menuts que en la anterior composició, d'uns $\mathbf{2 0}$ micròmetres de diàmetre, amb estructures cristal·lines que creixen prop de la superfície, amb fases riques amb calci, i vidre ric en sílice més cap a l'interior de l'esmalt.

A continuació s'observa la superfície, a la Figura 43, on es troben dos tipus de cristalls molt diferents, uns en forma acicular i els altres amb una forma molt menys definida, tots rics en calci. 


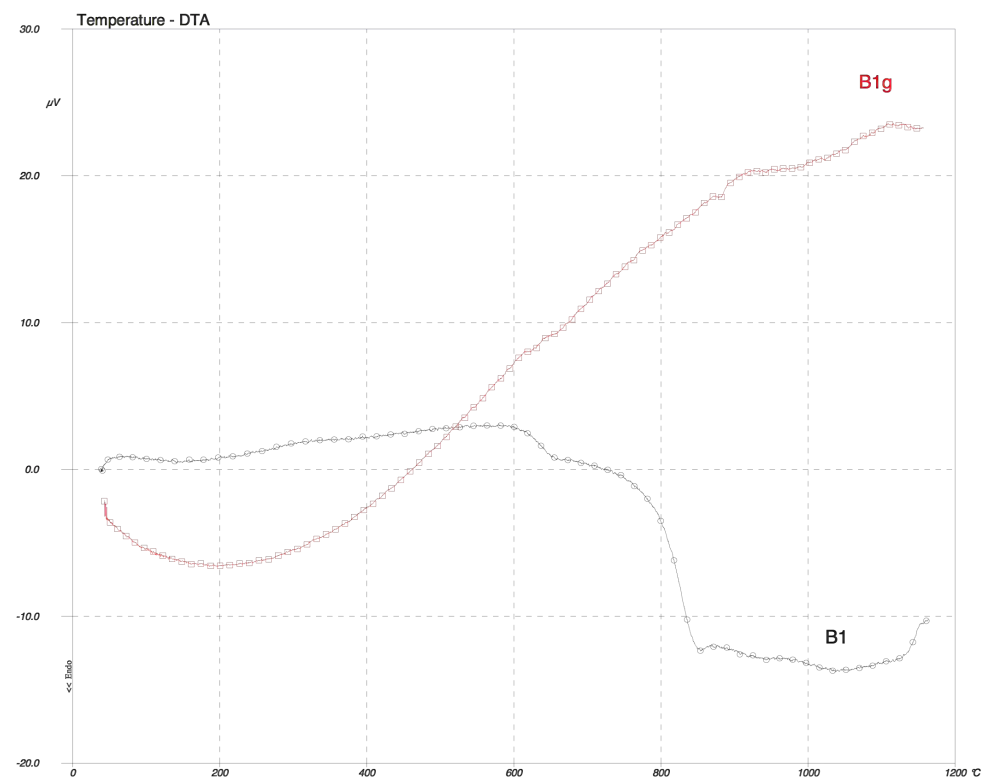

Figura 41 Anàlisis Tèrmiques Diferencial i Termogravimètrica de la composició B1.

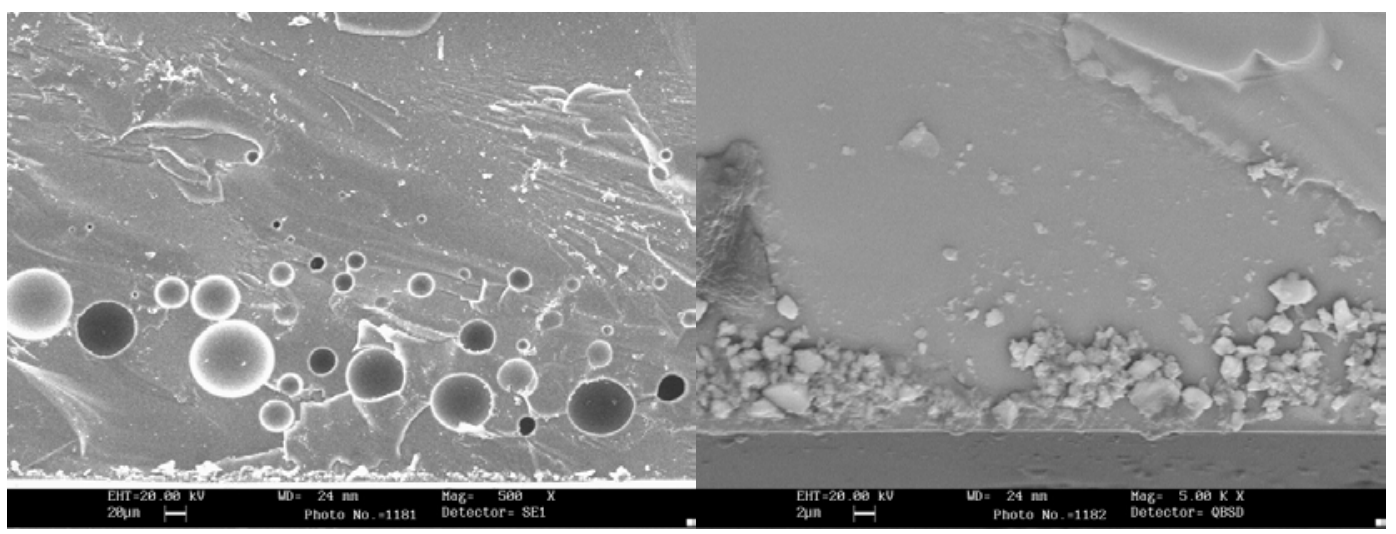

Figura 42 Micrografia de la secció de la composició B1 amb una hora de manteniment a 1000C.

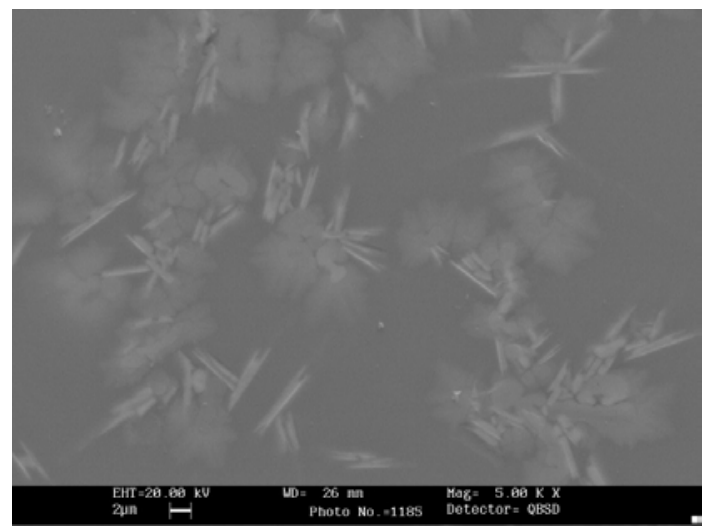

Figura 43 Micrografia de la superfície de la composició B1 amb una hora de manteniment a 1000C. 
A la Taula 16 s'aprecien els resultats de les anàlisis EDX de les diferents fases formades en aquesta peça, que indiquen que la fase cristal·lina és rica en calci i la fase vítria en sílice.

Taula 16 Microanàlisis per dispersió d'energies de raigs $X$ de la superfície de la composició $B 1$ amb $1 \mathrm{~h}$ de manteniment a 1000 ㅇ. .

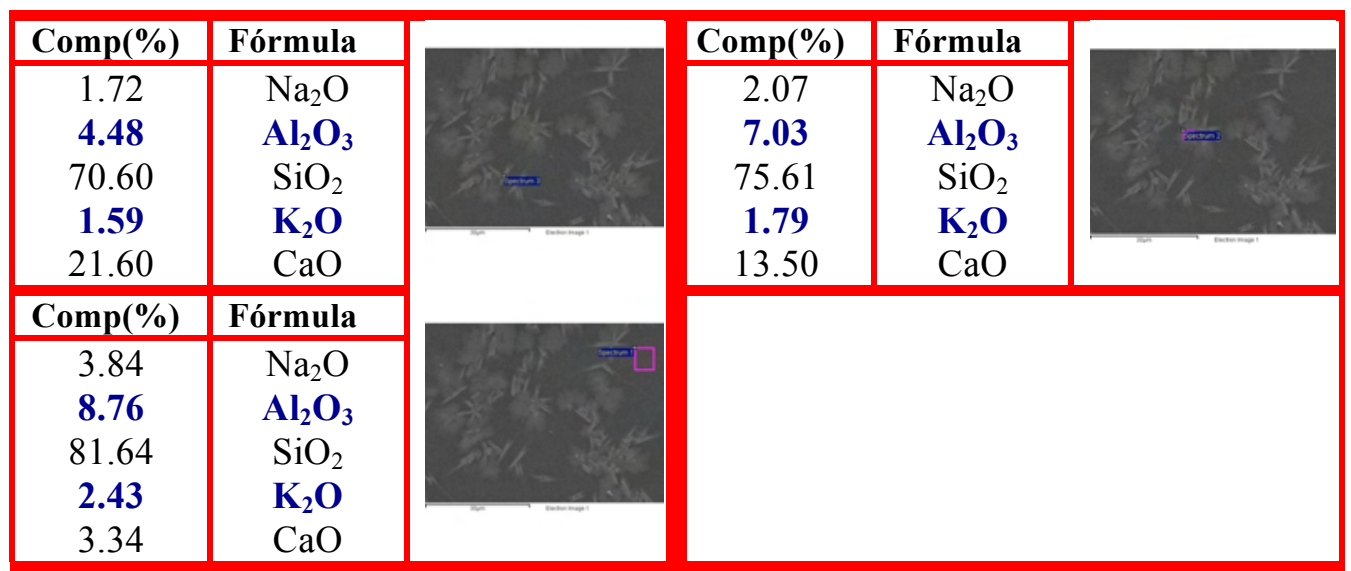

Si es comparen els resultats obtinguts per anàlisi SEM en aquest cicle amb els que s'obtenen a cocció estàndard, es comprova com desapareixen els cristalls a la composició B1. En primer lloc s'estudia un tall recent de la peça a la Figura 44, i quan s'observa la superfície, a la Figura 45 es comprova que no hi ha molts cristalls de mida considerable.

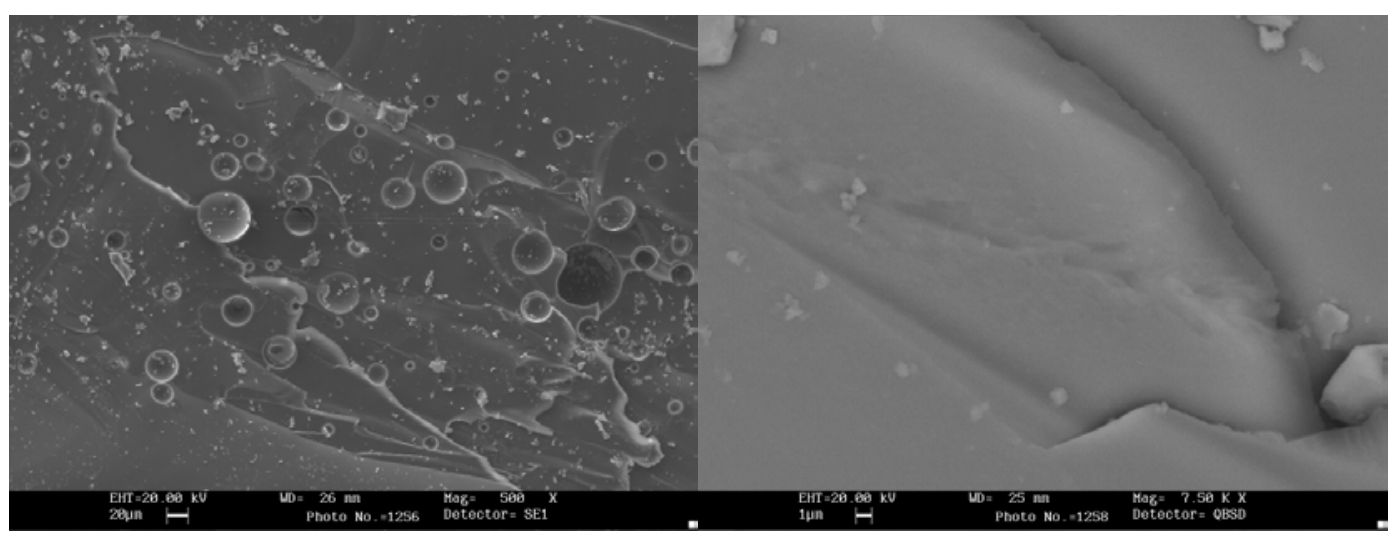

Figura 44 Micrografia de la secció de la composició B1 a cicle de cocció estàndard.

Per un altre costat, l'anàlisi semiquantitativa obtinguda per anàlisi EDX de la secció de la composició B1 a cicle estàndard es presenta a la Taula 17.

Novament, aquests resultats concorden amb els obtinguts per DRX, ja que per una banda es troben més estructures cristal·lines en la peça que ha estat $1 \mathbf{h}$ a $\mathbf{1 0 0 0}^{\circ} \mathbf{C}$ que en la que no ha tingut cap tipus de manteniment. 


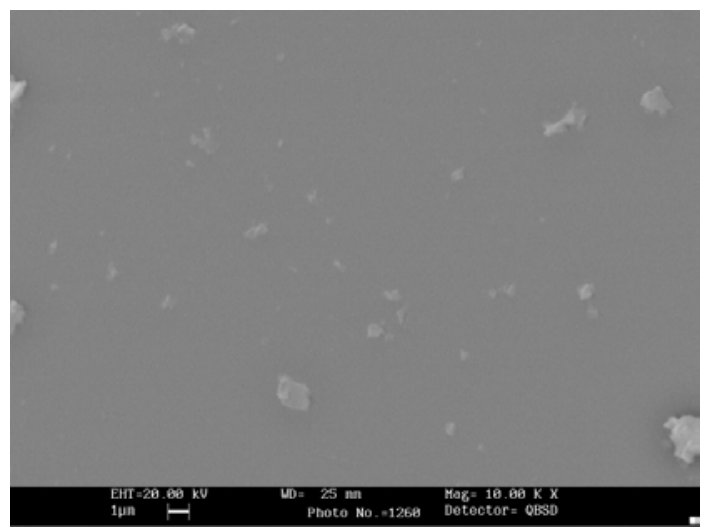

Figura 45 Micrografia de la superfície de la composició B1 a cicle de cocció estàndard.

Taula 17 Microanàlisi per dispersió d'energies de raigs $X$ de la secció de la composició B1 a cicle de cocció estàndard.

\begin{tabular}{|l|l|l|}
\hline Comp(\%) & Fórmula & \\
\hline 5.31 & $\mathrm{Na}_{2} \mathrm{O}$ & \\
$\mathbf{2 1 . 3 1}$ & $\mathbf{A l}_{2} \mathbf{O}_{3}$ & \\
70.20 & $\mathrm{SiO}_{2}$ & \\
$\mathbf{1 . 8 8}$ & $\mathbf{K}_{\mathbf{2}} \mathbf{O}$ & \\
1.31 & $\mathrm{FeO}$ & \\
\hline
\end{tabular}

A més, a les imatges es veu clarament que els cristalls estan molt orientats, cosa que explica la distorsió de l'espectre obtingut sobre la superfície de la peça, on hi ha una cara del cristall que creix molt més que les altres, provocant que unes línies del difractograma cresquen molt més en proporció que les altres. Aquest efecte es pot observar en els difractogrames de la Figura 46 , on $\mathbf{B}$ és el borat de sodi i $\mathbf{S}$ el silicat de calci.

A continuació s'observa el TTT mesurat a la superfície de les peces de la composició B1 de la fase amb l'estructura de borat de sodi, no es troba una correlació clara entre la proporció i el tipus de fases formades.

En aquests diagrames els punts buits representen fase amorfa, els punts grocs representen proporcions entre el 50 i el $\mathbf{8 0 \%}$ de fase, els verds entre el 80 i el $\mathbf{9 0 \%}$ i els blaus quan les fases, calculades com la relació $\mathbf{I}_{\text {neta }} / \mathbf{I}_{\text {bruta }}$, estan per damunt del $\mathbf{9 0 \%}$. Els resultats es poden veure a la Figura 47. 


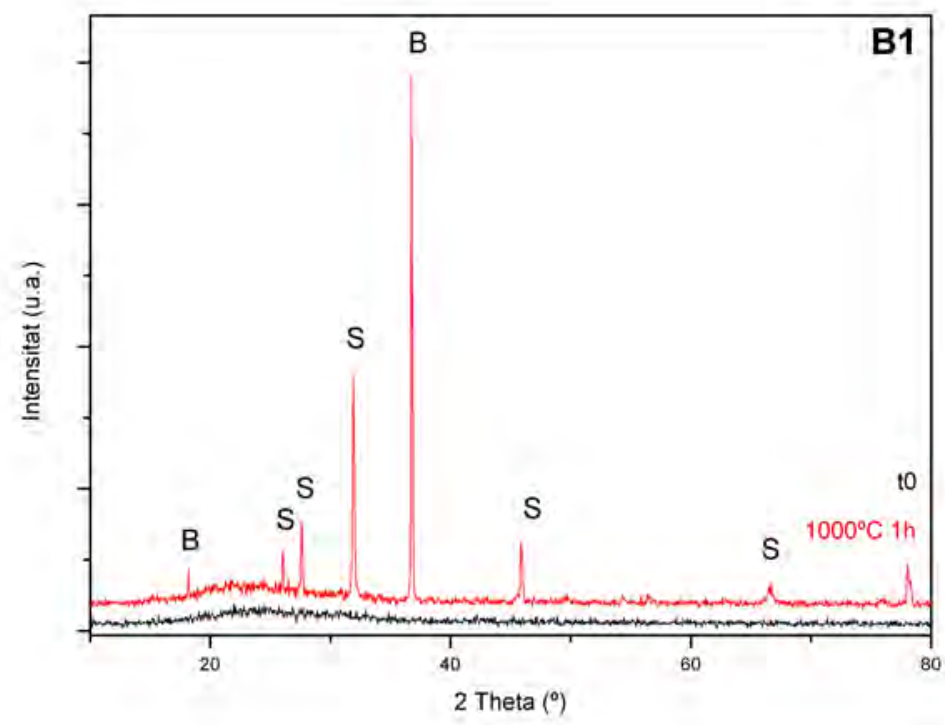

Figura 46 Difractograma de la superfície de la composició B1 amb 1h a 1000C $\mathrm{i}$ a cicle de cocció estàndard.

\section{TTT BORAT SÒDIC B1}

1250
1200
1150
1100
음 1050
1000
950
900
850

0

10

20

30

40

50

60

70

4 si $90 \%<$ que la fase formada a la superfície

4 Si la fase formada està entre el $90 \mathrm{i}$ el $80 \%$

Si la fase formada està entre el $50 \mathrm{i}$ el $80 \%$

$\triangle$ Si la fase formada està per baix del $50 \%$

Figura 47 Diagrama Transformació-Temperatura-Temps de la fase borat de sodi a la superfície de la composició B1.

L'altra fase que apareix, el silicat de calci, sols es troba a $\mathbf{1 0 0 0}^{\circ} \mathbf{C}$, i sols amb una hora de manteniment apareix quantificada per damunt del $\mathbf{5 0 \%}$. Per tant, no es pot establir una correlació clara de les fases presents a la superfície i el manteniment a diferents temperatures i temps per aquesta composició a la superfície del vidriat. 
Es fan assajos amb botons de fusió a diferents temperatures, i es conclou que, tant a $\mathbf{1 2 0 0}^{\circ} \mathrm{C}$ com a $\mathbf{9 0 0}^{\circ} \mathrm{C}$, les mostres apareixen amorfes, com apareix a la Taula 18.

Taula 18 Composició mineralògica dels botons de fusió de la composició B1.

\begin{tabular}{|c|c|c|}
\hline Temperatura $\left({ }^{\mathbf{}} \mathbf{C}\right)$ & Temps (min) & Borat sòdic \\
\hline 1200 & 0 & Amorf \\
\hline 1150 & 10 & Amorf \\
\hline 900 & 60 & Amorf \\
\hline
\end{tabular}




\subsubsection{Composició E1.}

En primer lloc, es revisen els resultats de l'anàlisi química en percentatge en pes de la composició E1, a la Taula 19, on es veu que és una composició rica en ferro, cosa que provoca la seva coloració marró. A continuació es presenten els resultats obtinguts amb microscopi de calefacció a la Taula 20 , on s'indica que la temperatura de fusió està novament molt per damunt de la temperatura de cocció.

Taula 19 Anàlisi química en pes de la composició E1.

\begin{tabular}{|l|l|l|l|l|l|l|l|l|l|l|l|}
\hline \multirow{2}{*}{ E1 } & $\mathrm{Al}_{2} \mathrm{O}_{3}$ & $\mathbf{S i O}_{2}$ & $\mathrm{Na}_{2} \mathrm{O}$ & $\mathbf{M g O}$ & $\mathrm{K}_{2} \mathrm{O}$ & $\mathbf{C a O}$ & $\mathrm{TiO}_{2}$ & $\mathbf{F e}_{2} \mathbf{O}_{3}$ & $\mathrm{Li}_{2} \mathrm{O}$ & $\mathbf{B}_{2} \mathbf{O}_{3}$ & $\mathrm{PPC}$ \\
\cline { 2 - 11 } & 25.2 & $\mathbf{5 0 . 4}$ & 1.59 & $\mathbf{1 . 7 1}$ & 3.35 & $\mathbf{3 . 4 1}$ & 0.58 & $\mathbf{8 . 3 6}$ & 3,5 & $\mathbf{2 , 4}$ & +0.95 \\
\hline
\end{tabular}

Taula 20 Temperatures característiques de la composició E1, mesurades amb microscopi de calefacció.

\begin{tabular}{|l|c|}
\hline & E1 $\left({ }^{\circ} \mathbf{C}\right)$ \\
\hline Sinterització & 1041 \\
\hline Reblaniment & 1098 \\
\hline Mitja esfera & 1175 \\
\hline Fusió & 1271 \\
\hline
\end{tabular}

A 1'ATD/TG, Figura 48, es veu un pic de cristal-lització a $8^{\circ} 5^{\circ} \mathrm{C}$ a la composició molturada i comença la segona cristal·lització a $\mathbf{1 0 8 0}^{\circ} \mathrm{C}$. En el gra de frita $(\mathbf{E 1 g})$ sols apareix la segona cristal·lització, cosa que indica que la primera reacció és heterogènia o superficial i la segona homogènia o volumètrica.

Per altra banda, les micrografies de la composició E1 s'han fet sobre una peça cuita amb un manteniment en el refredament a $1200^{\circ} \mathrm{C}$, amb 1 hora de manteniment. Si s'observa la

Figura 49, a la secció recent es troben cristalls molt menuts, d'un micròmetre de diàmetre. En canvi, s'observa com la superfície està totalment coberta de silicat de ferro. 


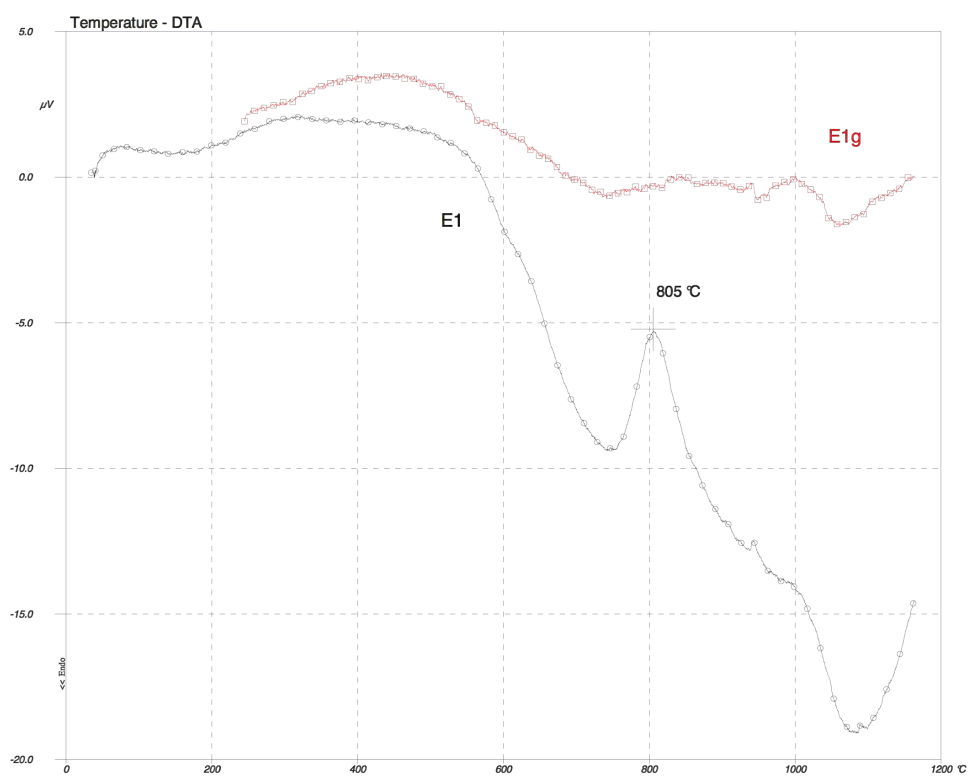

Figura 48 Anàlisis tèrmiques diferencial i termogravimètrica de la composició E1.

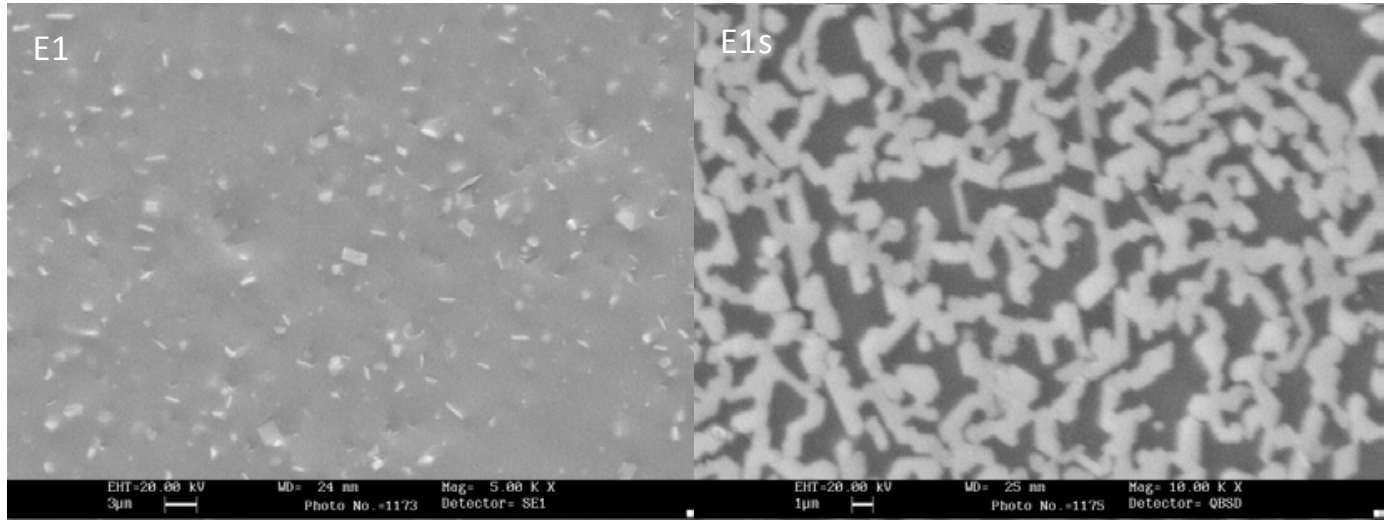

Figura 49 Micrografia de la secció (E1) i de la superfície (E1s) de la composició E1 amb una hora de manteniment a $1200 \div$ C.

A la Taula 21 es presenten els resultats de les anàlisis químiques semiquantitatives de la secció, obtingudes per EDX, on la fase cristal·lina apareix molt més rica en ferro que la fase vítria.

Taula 21 Microanàlisis per dispersió d'energies de raigs $X$ de la secció de la composició $E 1$ amb 1 h de manteniment a 1200 ㅇ. .

\begin{tabular}{|c|c|c|c|c|}
\hline Comp\% & Fórmula & Comp\% & Fórmula & \\
\hline & & 4.99 & $\mathrm{Na}_{2} \mathrm{O}$ & $=$ \\
\hline 2.80 & $\mathrm{Na}_{2} \mathrm{O}$ & 23.02 & $\mathrm{Al}_{2} \mathrm{O}_{2}$ & \\
\hline 13.40 & $\mathrm{Al}_{2} \mathbf{O}_{3}$ & 5346 & $\mathrm{SiO}_{2}$ & \\
\hline 24.43 & $\mathrm{SiO}_{2}$ & 3.05 & $\begin{array}{l}\mathrm{NIO}_{2} \\
\mathrm{~K}, \mathrm{O}\end{array}$ & \\
\hline 1.76 & $\mathrm{CaO}$ & 5.15 & $\mathrm{CaO}$ & \\
\hline 2.74 & $\mathrm{TiO}_{2}$ & 4.58 & $\mathrm{FeO}$ & \\
\hline 54.85 & $\mathrm{FeO}$ & $\begin{array}{l}\mathbf{4}+50 \\
5.75\end{array}$ & $\mathrm{ZrO}_{2}{ }^{*}$ & \\
\hline
\end{tabular}


Si es compara amb la peça obtinguda sense manteniment durant el refredament, el cicle estàndard, aquests cristalls no s'observen a l'interior de l'esmalt, a la Figura 50. En canvi, a la superfície, en la Figura 51, es troba que hi ha cristalls de silicat de ferro en el si d'un vidre ric en sílice.

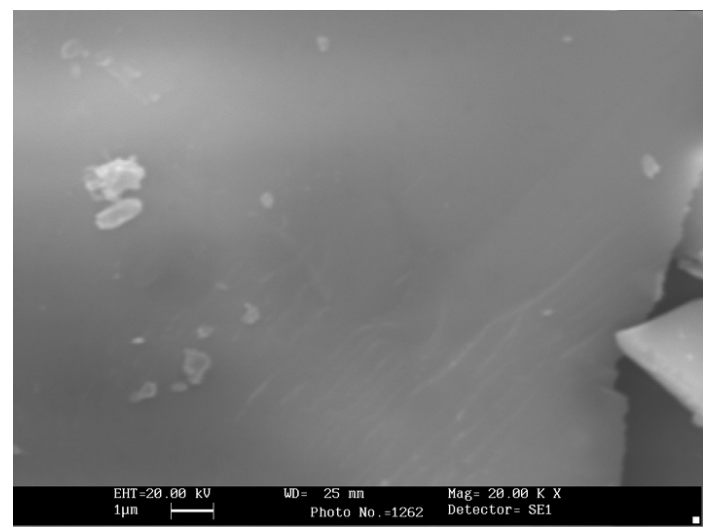

Figura 50 Micrografia de la secció de la composició E1 a cicle de cocció estàndard.

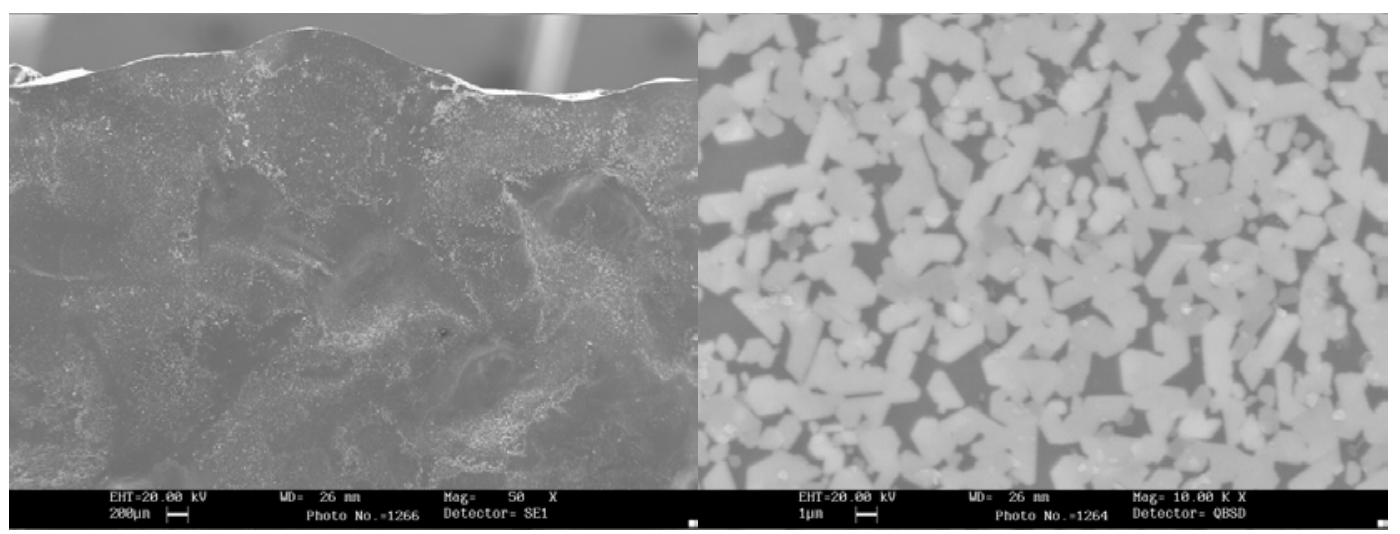

Figura 51 Micrografia de la superfície de la composició E1 a cicle de cocció estàndard.

Així, es conclou per tant que les superfícies són bastant similars, de manera que a cicles curts es desenvolupen cristalls a la superfície i en augmentar el temps de manteniment es formen cristalls cap a l'interior. A la Taula 22 es pressenten les anàlisis semiquantitatives de la composició E1 a cicle estàndard, obtingudes per EDX:

Taula 22 Microanàlisis per dispersió d'energies de raigs $X$ de la composició $E 1$ a cicle de cocció estàndard.

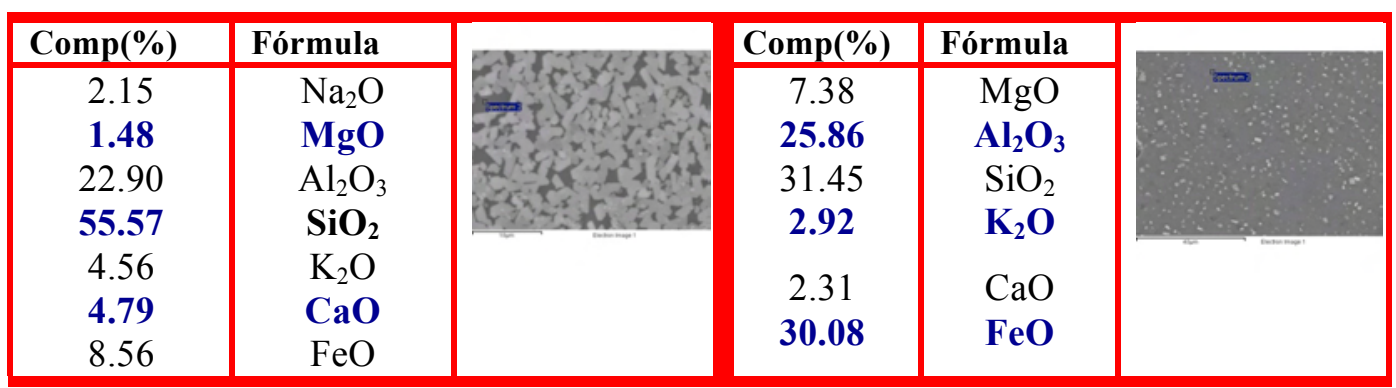


Si s'observen els DRX de la superfície dels vidriats, a la Figura 52, es troben les mateixes fases cristal·lines, molt més desenvolupades a major temps de manteniment:

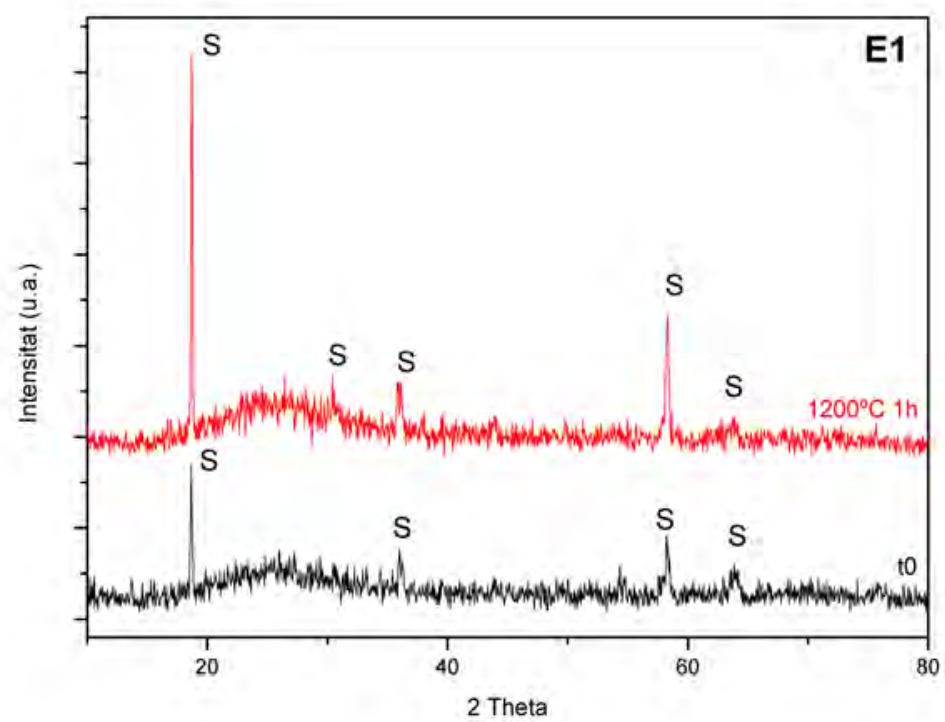

Figura 52 Difractograma de la superfície de la composició E1 amb 1h a 1200C i a cicle de cocció estàndard.

A continuació es mostra el TTT mesurat a la superfície dels vidriats de les peces de la composició $\mathbf{E} 1$ de la fase amb l'estructura de silicat de ferro, calculat a partir del ràtio $\mathbf{I}_{\text {neta }} / \mathbf{I}_{\text {bruta. }}$. Al diagrama, en la Figura 53, s'intueix que augmenta la proporció de silicat de ferro a la superfície quan augmenta el temps de manteniment, tot i que els resultats no són concloents.

TTT E1 SILICAT DE FERRO

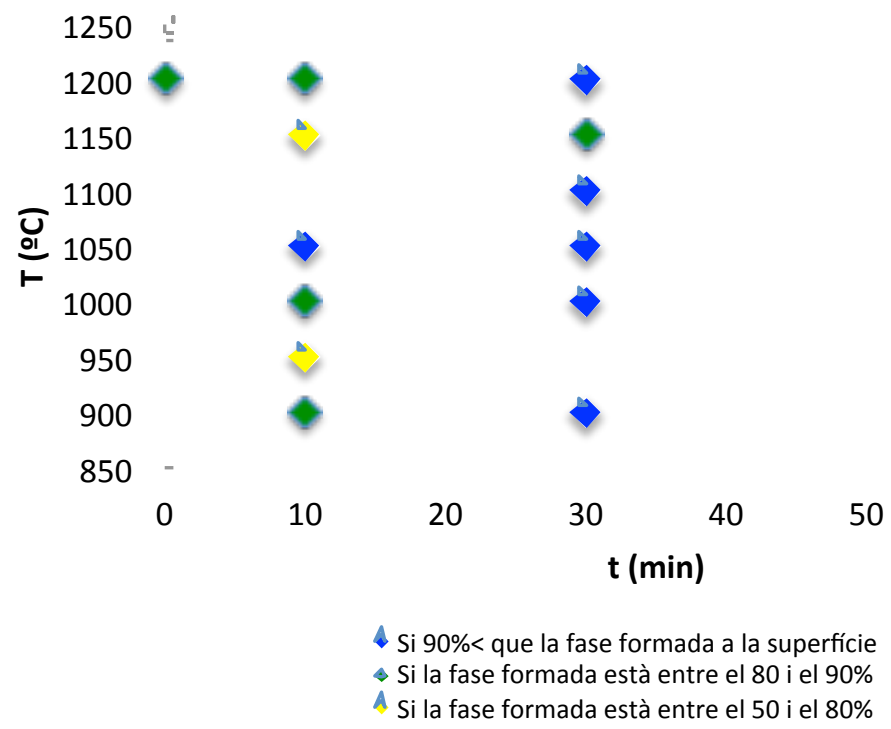

Figura 53 Diagrama Transformació-Temperatura-Temps de la fase silicat de ferro a la superfície de la composició E1. 
Cal destacar que la niofil-lita a la superfície del vidriat, sols es desenvolupa quan es fa manteniment a $900^{\circ} \mathrm{C}$, i no es detecta per a manteniments a temperatures majors ni al cicle estàndard a la superfície. També apareixen línies als difractogrames que podrien indicar la presència d'hematites, però en una proporció molt reduïda.

Finalment, si es comparen els resultats del TTT de les superfícies dels vidriats amb els resultats de les anàlisis sobre botons de fusió molturats, a Taula 23, s'aprecia com s'obtenen valors i fases molt diferents dels trobats a la superfície.

Taula 23 Composició mineralògica dels botons de fusió a la frita E1.

\begin{tabular}{|c|c|c|c|c|}
\hline Temperatura $\left({ }^{\mathbf{0}} \mathbf{C}\right)$ & Temps (min) & Silicat de ferro & Niobofil $\cdot$ lita & Hematites \\
\hline 1200 & 0 & 70 & 88 & 0 \\
\hline 1200 & 10 & 0 & 89 & 71 \\
\hline 900 & 60 & 0 & 96 & 0 \\
\hline
\end{tabular}

Es considera que aquests valors tant dispars, en part estan provocats perquè els vidriats estan punxats, amb el que es conclou que l'esmalt no és adequat per aquest cicle de cocció. No presenta un acabat estirat sense punxats en cap cas. 


\subsubsection{Composicions II i I2.}

Com les composicions I1 i I2 pertanyen a la mateixa sèrie, i tenen composicions molt paregudes, com es pot veure a la Taula 24, els resultats obtinguts s'estudiaran conjuntament. Es tracta de composicions riques en calci i amb continguts mitjans de sodi, magnesi i ferro. A continuació, a la Taula 25, es mostren les anàlisis amb microscopi de calefacció, on es comprova que la composició I1 és més fundent que la I2:

Taula 24 Anàlisis químiques en pes de les composicions I1 i 12.

\begin{tabular}{|l|l|l|l|l|l|l|l|l|l|l|l|}
\hline & $\mathbf{A l}_{2} \mathbf{O}_{3}$ & $\mathbf{S i O}_{2}$ & $\mathbf{N a}_{2} \mathbf{O}$ & $\mathbf{M g O}$ & $\mathbf{K}_{2} \mathbf{O}$ & $\mathbf{C a O}$ & $\mathbf{T i O}_{2}$ & $\mathbf{F e}_{2} \mathbf{O}_{3}$ & $\mathbf{L i}_{2} \mathbf{O}$ & $\mathbf{B}_{2} \mathbf{O}_{3}$ & $\mathbf{P P C}$ \\
\hline $\mathbf{I 1}$ & 7.88 & 54.2 & 8.16 & 8.06 & 0.53 & 15.6 & 0.21 & 4.82 & $<0,1$ & $<0,25$ & +0.11 \\
\hline I2 & 11.7 & 53.0 & 7.04 & 6.54 & 1.06 & 13.2 & 0.30 & 6.67 & $<0,1$ & $<0,25$ & +0.22 \\
\hline
\end{tabular}

Taula 25 Temperatures característiques de les composicions I1 i 12, mesurades amb microscopi de calefacció.

\begin{tabular}{|l|c|c|}
\hline & I $1\left(^{\circ} \mathbf{C}\right)$ & I2 $\left({ }^{\circ} \mathbf{C}\right)$ \\
\hline Sinterització & 774 & 808 \\
\hline Reblaniment & 900 & 950 \\
\hline Mitja esfera & 1242 & 1242 \\
\hline Fusió & 1256 & 1286 \\
\hline
\end{tabular}

En l'ATD/TG de la composició I1, representat en la Figura 54, es veu clarament una forta cristal-lització a partir de $\mathbf{8 0 0}^{\circ} \mathrm{C}$, quan ha acabat la sinterització. Eixa cristal·lització té un màxim molt clar a $863^{\circ} \mathrm{C}$. Hi ha una segona cristal·lització a partir de $\mathbf{1 0 0 0}^{\circ} \mathrm{C}$, esta vegada homogènia, com es dedueix a partir de l'anàlisi d'un gra de frita.

Per altra banda, a la composició I2, a la Figura 55, aquesta primera cristal·lització es desplaça a temperatures majors, presentant el màxim a $910^{\circ} \mathrm{C}$. Al contrari que en la composició I1, aquesta cristal·lització es reflectís al gra de frita de composició $\mathbf{2} 2$ però desplaçada cap a temperatures més altes encara. La segona cristal·lització pareix arribar al màxim a valors propers a $\mathbf{1 1 5 0}^{\circ} \mathrm{C}$ en el cas del gra de frita i la corba baixa ràpidament a $1^{1100}{ }^{\circ} \mathrm{C}$ en el cas de la frita molturada. 


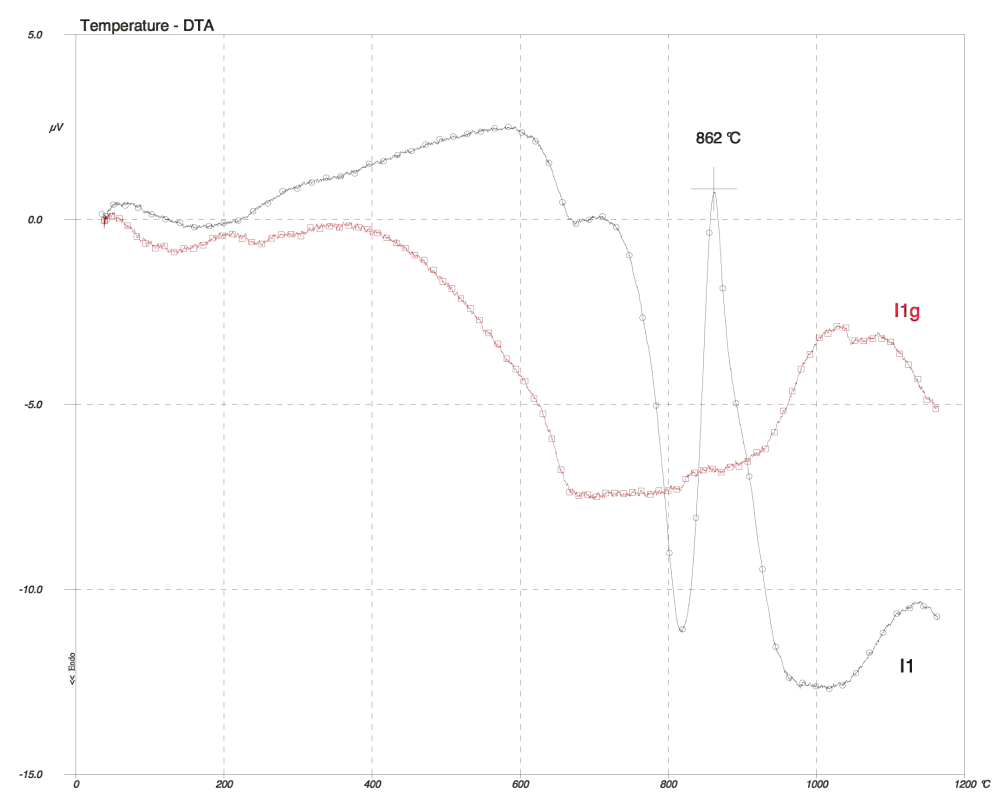

Figura 54 Anàlisis tèrmiques diferencial i termogravimètrica de la composició I1.

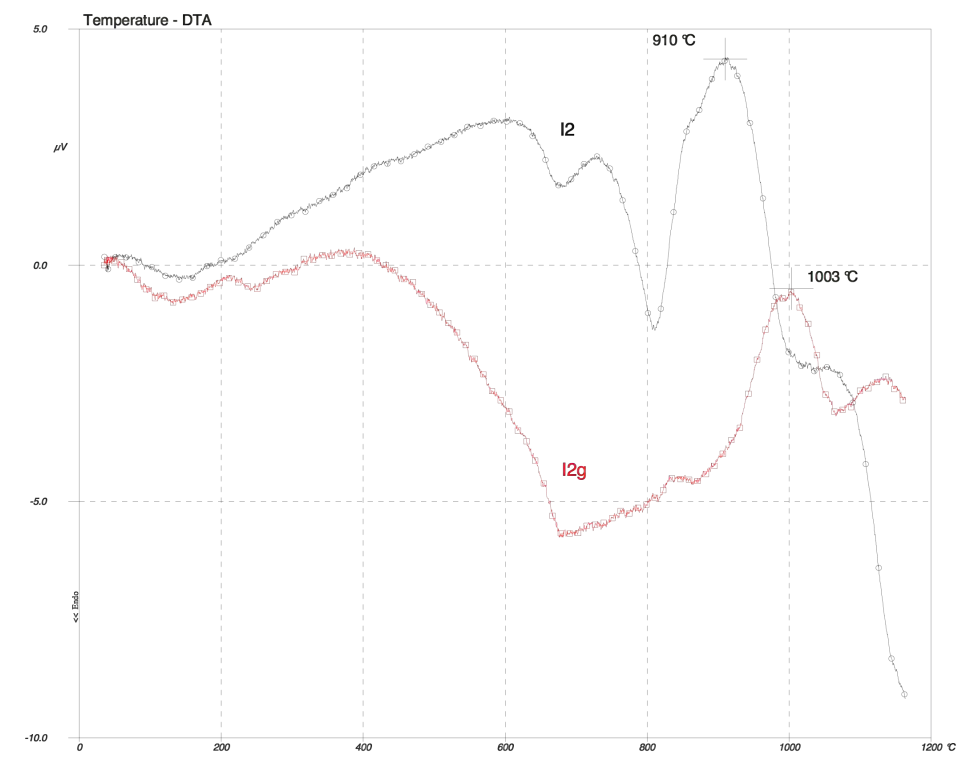

Figura 55 Anàlisis tèrmiques diferencial i termogravimètrica de la composició 12.

Les micrografies de les composicions I1 i I2 s'han fet sobre peces cuites amb un manteniment d'una hora en el refredament a $\mathbf{1 0 0 0}^{\circ} \mathbf{C}$. Si s'observa una secció recent del vidriat de la composició I1, a la Figura 56, apareix una estructura cristal·lina amb molt poca fase vítria. Els cristalls són paral·lepípeds molt menuts, d'un parell de micròmetres 
de llarg. Les fases cristal·lines són riques en calci (augita) i la fase vítria en sodi. D’altra banda, la micrografia de la superfície (I1s) presenta cristalls en forma de irregularitats.

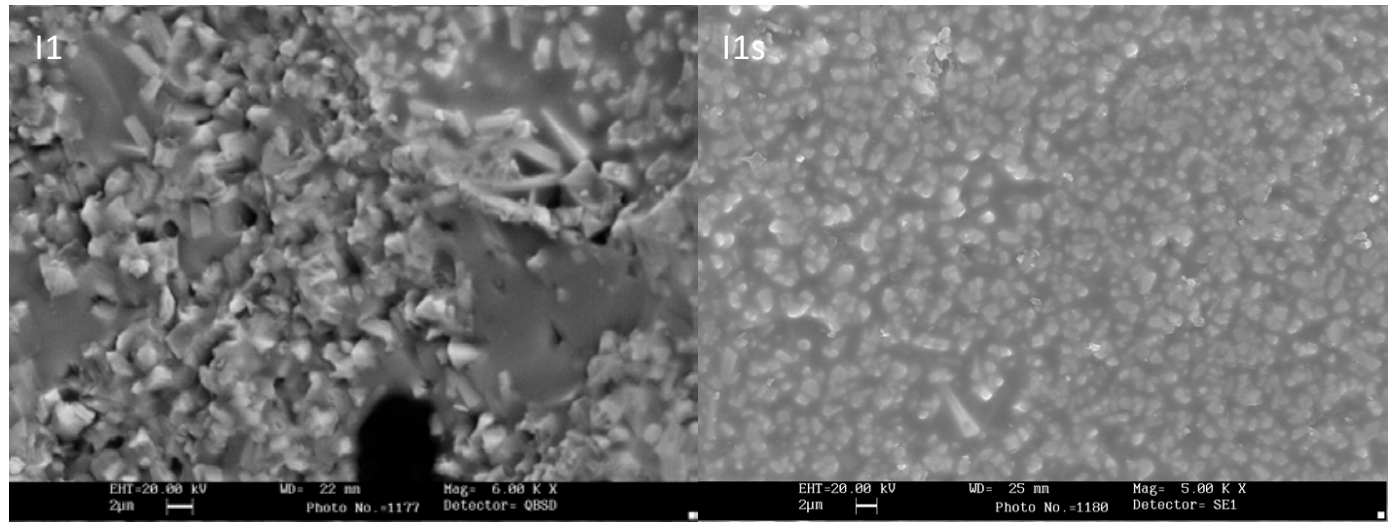

Figura 56 Micrografies de la secció (I1) i de la superfície (I1s) de la composició I1 amb una hora de manteniment a 1000 ㄷ.

A continuació, a la Taula 26 es pot veure com la composició I1 pareix contenir percentatges majors de ferro i calci a la superfície que a la secció de la peça.

Taula 26 Microanàlisis per dispersió d’energies de raigs $X$ de la composició $\mid 1$ amb 1 hora de manteniment a 1000 ㅇ. .

\begin{tabular}{|c|c|c|c|c|c|}
\hline $\operatorname{Comp}(\%)$ & Fórmula & & $\operatorname{Comp}(\%)$ & Fórmula & \\
\hline 5.50 & $\mathrm{Na}_{2} \mathrm{O}$ & & 5.50 & $\mathrm{Na}_{2} \mathrm{O}$ & \\
\hline 9.43 & MgO & & 6.12 & MgO & \\
\hline 8.58 & $\mathrm{Al}_{2} \mathrm{O}_{3}$ & & 7.72 & $\mathrm{Al}_{2} \mathrm{O}_{3}$ & \\
\hline 56.62 & $\mathrm{SiO}_{2}$ & & 54.97 & $\mathrm{SiO}_{2}$ & \\
\hline 14.91 & $\mathrm{CaO}$ & & 18.58 & $\mathrm{CaO}$ & \\
\hline 4.96 & $\mathrm{FeO}$ & & 7.11 & $\mathrm{FeO}$ & \\
\hline
\end{tabular}

Per a la composició $\mathbf{I} 2$ aquesta cristal·lització massiva és encara més exagerada, com es pot observar a la Figura 57, on s'aprecia els paral·lepípeds d'augita orientada i els porus que queden a l'interior de l'esmalt.

Si s'observa la superfície del vidriat de la composició $\mathbf{I} 2$ amb 1 hora de manteniment a $1000^{\circ} \mathrm{C}$, a la Figura 58 , es troba una estructura similar, amb els mateixos cristalls: 


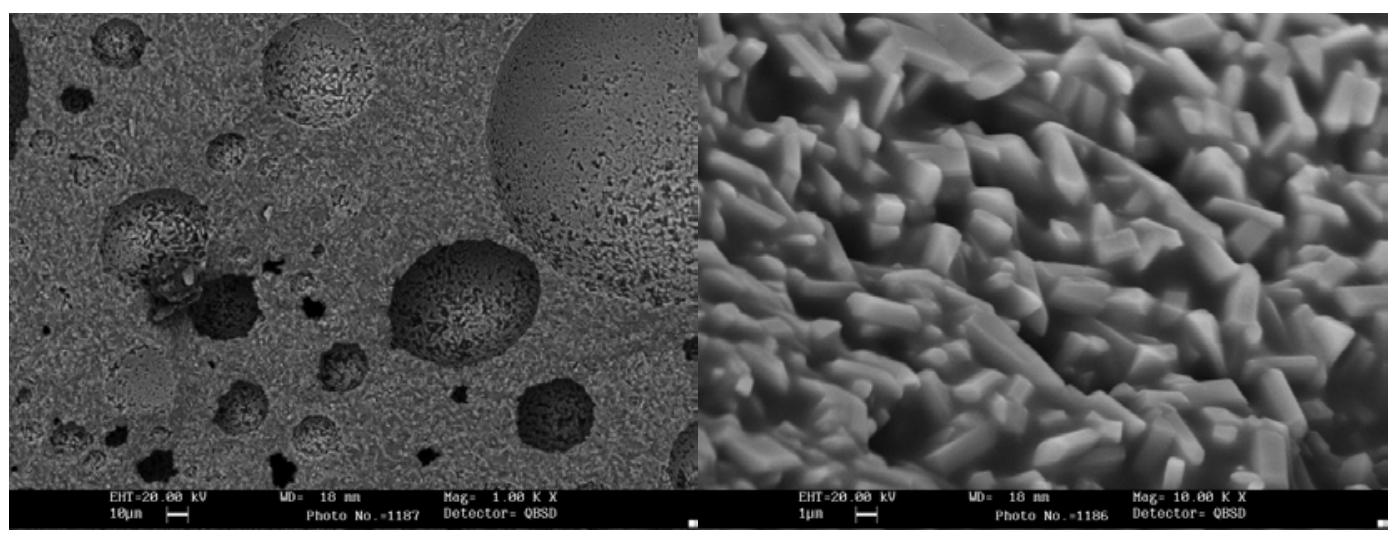

Figura 57 Micrografia de la secció de la composició 12 amb una hora de manteniment a 1000 으.

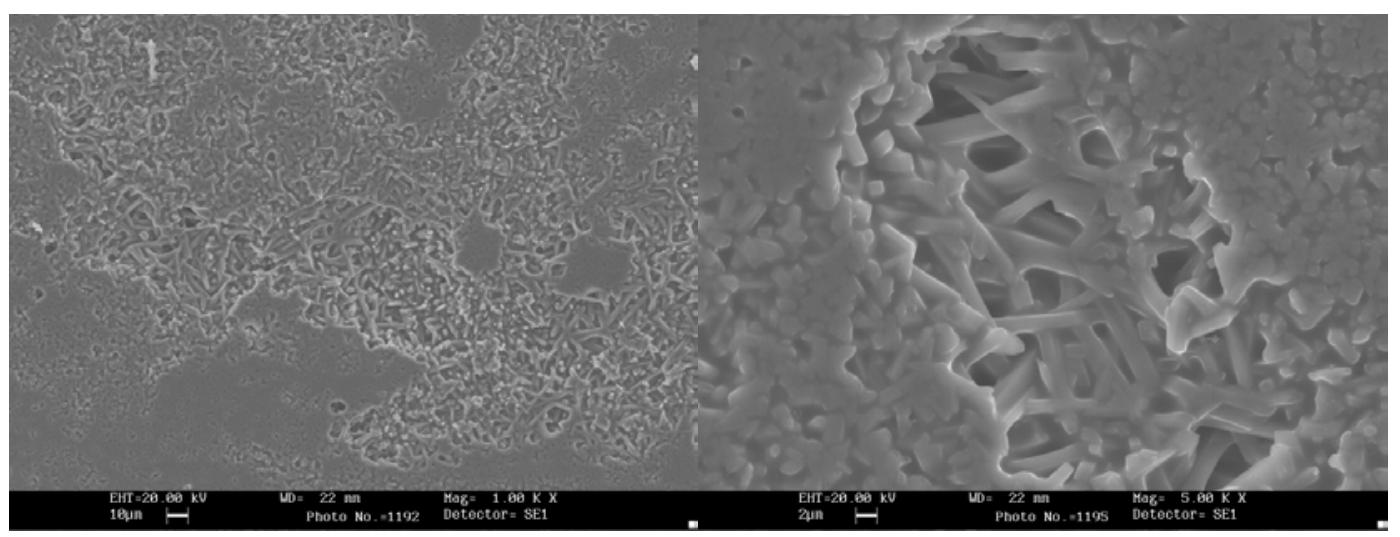

Figura 58 Micrografia de la superfície de la composició 12 amb una hora de manteniment a 1000 C.

A la Taula 27 s'observa una estimació de la composició de les fases presents feta per anàlisi EDX a la superfície, on s'aprecia que la quantitat d'òxid de calci és molt més gran on la fase cristal·lina està totalment desenvolupada.

Taula 27 Microanàlisis per dispersió d'energies de raigs $X$ de la superfície de la composició 12 amb 1 h de manteniment a 1000 으.

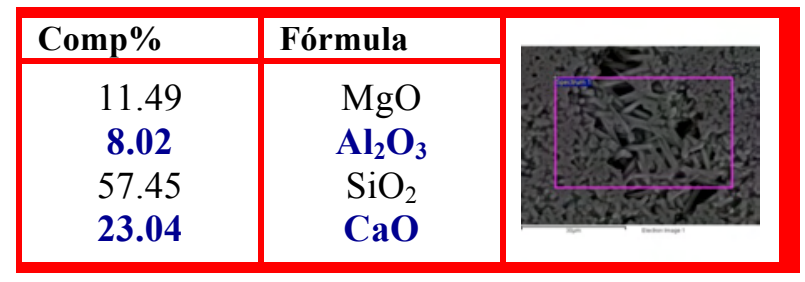

Si es comparen aquestes imatges amb les que s'obtenen de peces cuites a cicle estàndard, a la composició I1, trobem gran quantitat de porus grans, d'uns $\mathbf{4 0}$ micròmetres de diàmetre, i gran formació de cristalls, envoltats de fase vítria, a la Figura 
59. I a la superfície de la composició I1 tractada amb el cicle estàndard s'observen també gran quantitat de cristalls d'augita, rodejats per fase vítria, a la Figura 60:

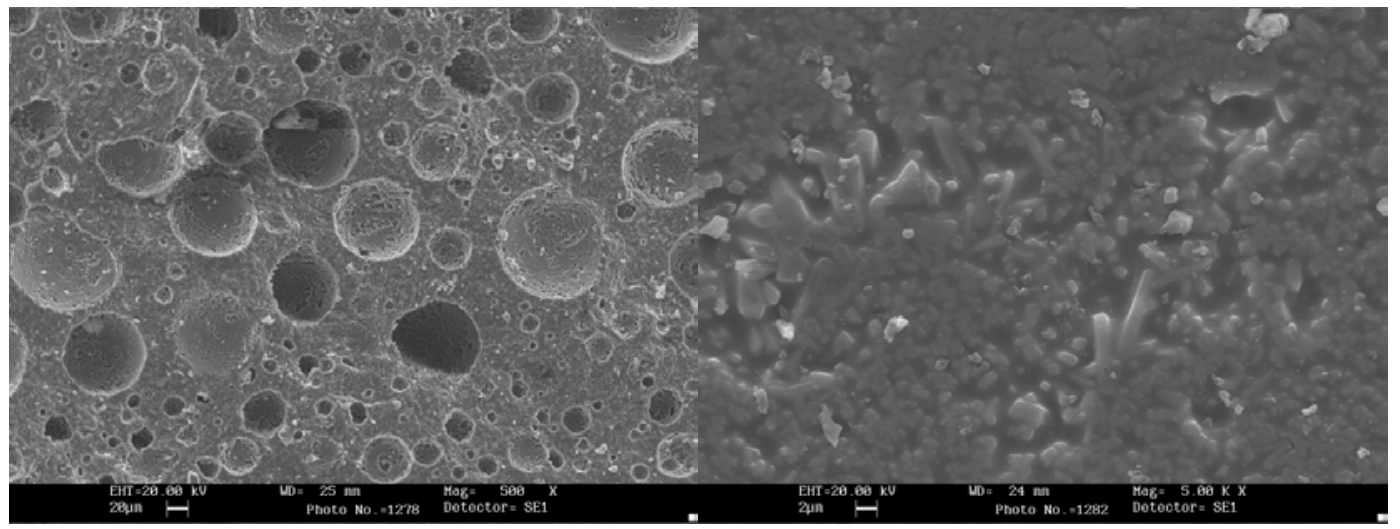

Figura 59 Micrografia de la secció de la composició I1 a cicle de cocció estàndard.

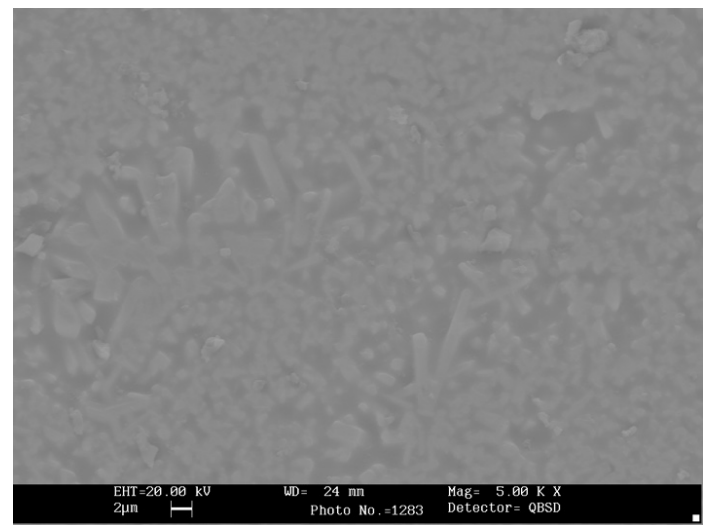

Figura 60 Micrografia de la superfície de la composició I1 a cicle de cocció estàndard.

A la Taula 28 es presenta una estimació de la composició química de la secció de la peça I1 a cicle estàndard, realitzada per EDX, on es torna a mostrar que quan augmenta la proporció de ferro i sodi el grau de cristal·lització pareix reduir-se.

Taula 28 Microanàlisis per dispersió d'energies de raigs $X$ de la secció de la composició $\mid 1$ a cicle estàndard.

\begin{tabular}{|c|c|c|}
\hline Comp\% & Fórmula & \\
\hline 4.91 & $\mathrm{Na}_{2} \mathrm{O}$ & \\
$\mathbf{6 . 2 0}$ & $\mathbf{M g O}$ & \\
8.22 & $\mathrm{Al}_{2} \mathrm{O}_{3}$ & \\
$\mathbf{5 2 . 4 3}$ & $\mathrm{SiO}_{2}$ & \\
19.38 & $\mathrm{CaO}$ & \\
$\mathbf{8 . 8 7}$ & $\mathbf{F e O}$ & \\
\hline
\end{tabular}

Si es comparem novament amb les imatges trobades per a la composició I2, a cicle estàndard, es dedueix que la cristal·lització trobada, a la Figura 61 és similar. A la Figura 62 es pot veure la superfície, pràcticament sense fase vítria en zones extenses. 


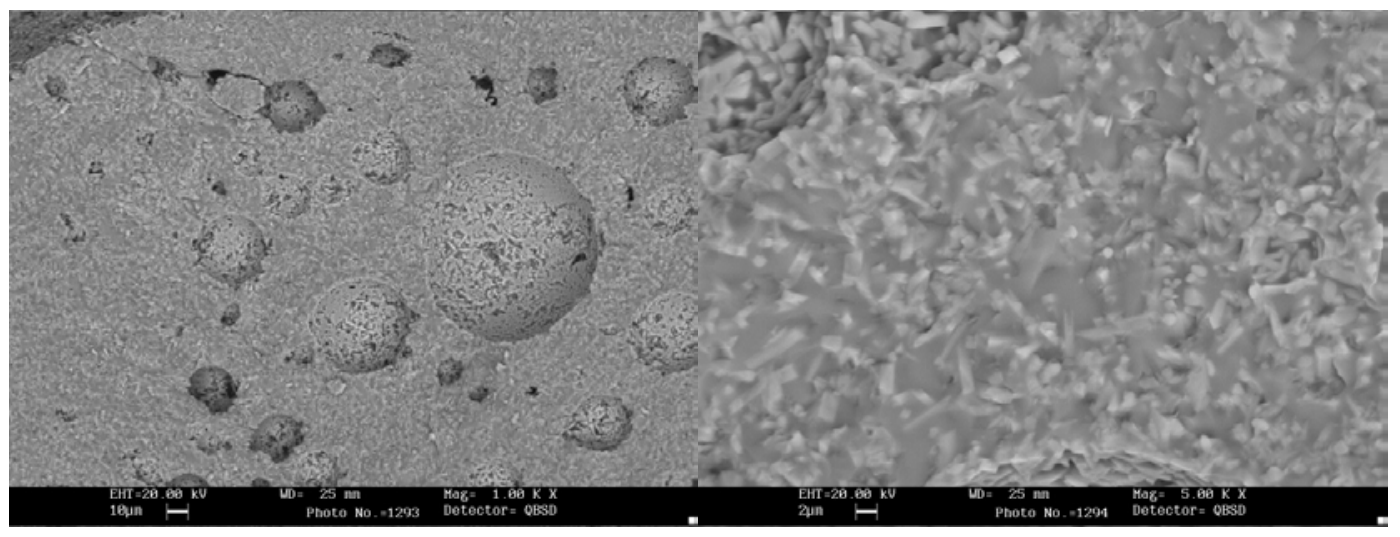

Figura 61 Micrografia de la secció de la composició I2 a cicle de cocció estàndard.

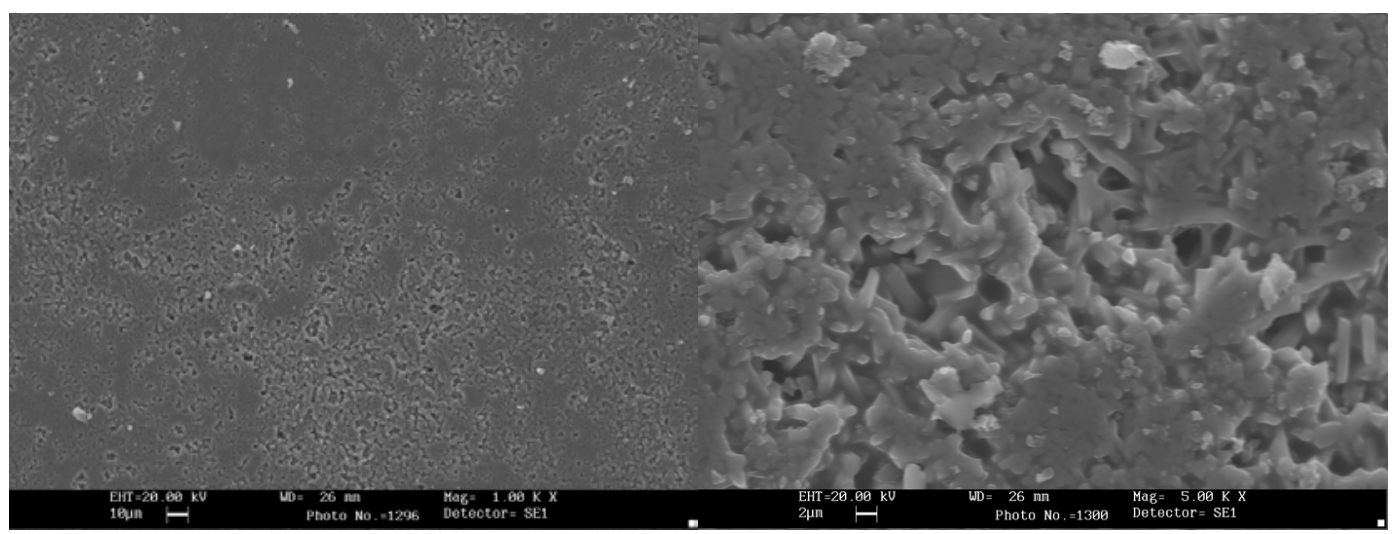

Figura 62 Micrografia de la superfície de la composició 12 a cicle de cocció estàndard.

Si s'observen les anàlisis EDX, a la Taula 29 es troba un contingut en òxid de calci similar als anteriors. Aquests resultats per a la composició I1 concorden amb els resultats obtinguts per anàlisi mineralògica amb DRX, que es mostren a la Figura 63, on s'identifiquen clarament tots els picus com augita. A la Figura 64 també es mostren totes les línies identificades de la composició I2. Novament sols apareix una fase cristal·lina, l'augita.

Taula 29 Microanàlisis per dispersió d'energies de raigs $X$ de la composició 12 a cicle estàndard.

\begin{tabular}{|c|c|c|}
\hline Comp\% & Fórmula & \\
\hline 3.48 & $\mathrm{Na}_{2} \mathrm{O}$ & \\
8.17 & $\mathrm{MgO}$ & \\
$\mathbf{5 4 . 4 3}$ & $\mathrm{SiO}$ \\
22.20 & $\mathrm{CaO}$ \\
$\mathbf{1 1 . 7 2}$ & $\mathrm{FeO}$ & \\
\hline
\end{tabular}




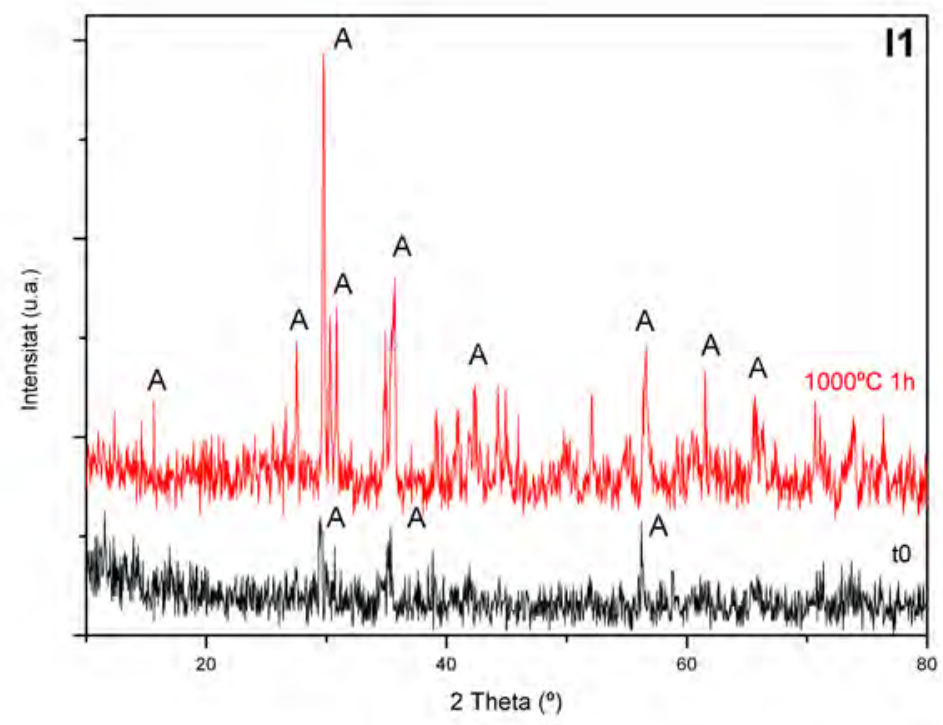

Figura 63 Difractograma de la superfície de la composició I1 amb $1 \mathrm{~h}$ a 1000C $\mathrm{i}$ a cicle de cocció estàndard.

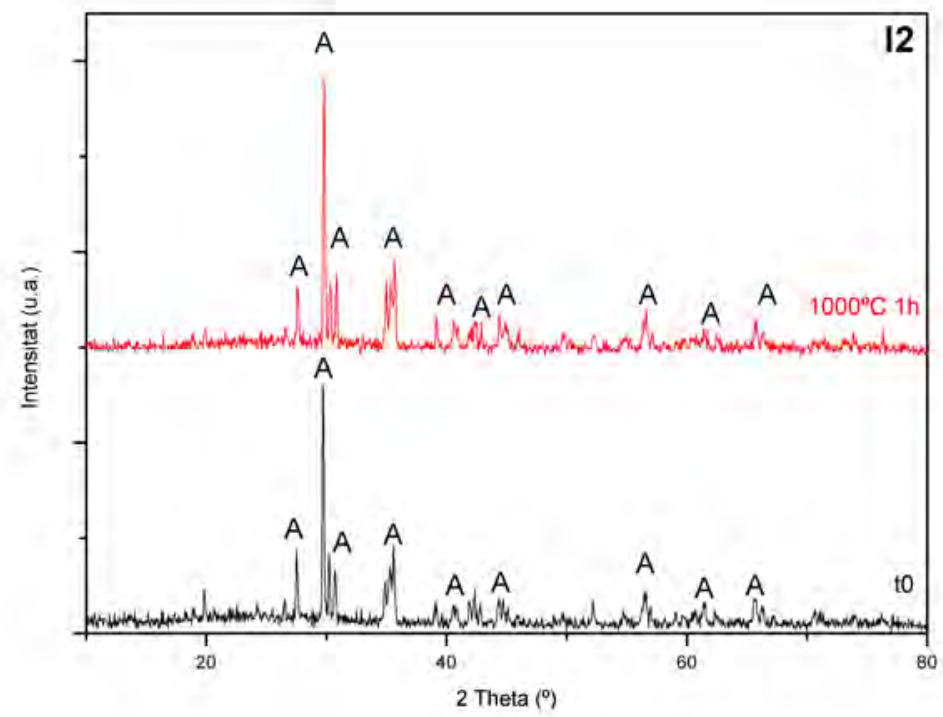

Figura 64 Difractograma de la superfície de la composició 12 amb 1h a 1000C i a cicle de cocció estàndard.

Els valors dels difractogrames de la superfície de les partícules són prou pareguts, com es mostren als diagrames TTT, si s'observen els percentatges de fases formades en I1 en el rang de l'estudi a diferents temps i temperatura, a la Figura 65.

Es mostra en blau els punts que corresponen a més d'un $\mathbf{9 0 \%}$ de fase cristal $\cdot$ lina d'augita i en verd més d'un $\mathbf{8 0} \%$, calculades a partir del ratio entre $\mathbf{I}_{\text {neta }} / \mathbf{I}_{\text {bruta. }}$. 


\section{TTT I1 AUGITA}

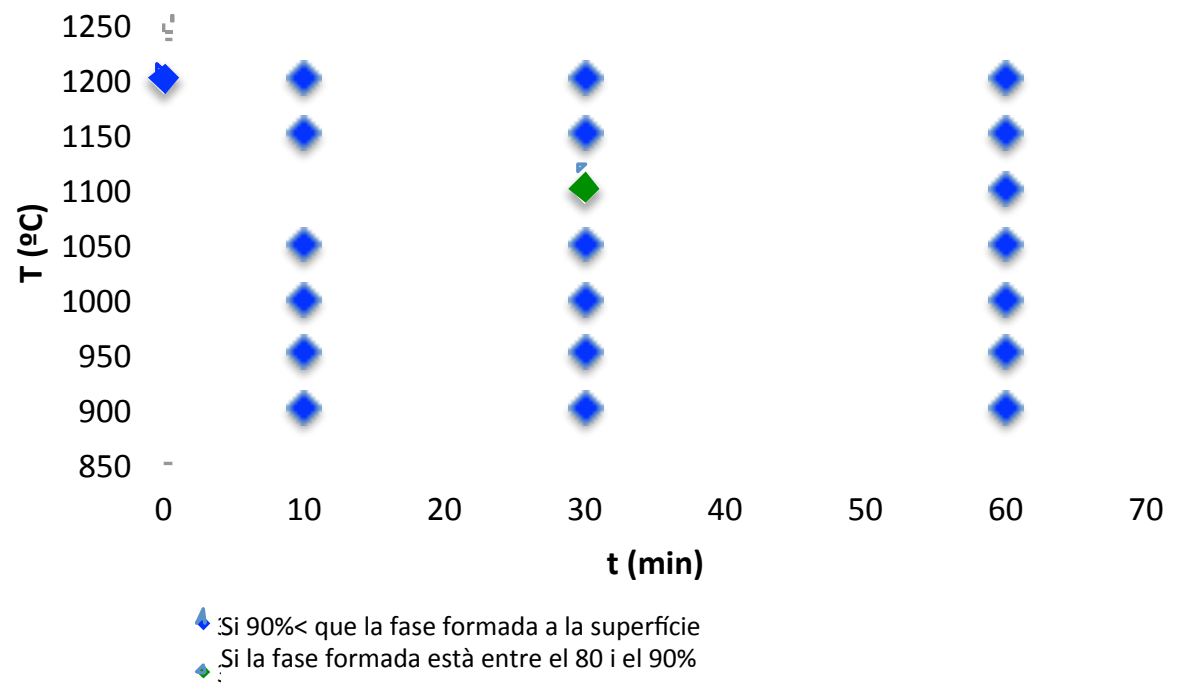

Figura 65 Diagrama Transformació-Temperatura-Temps de la fase augita a la superfície de la composició I1.

Per altra banda, per a la composició I2, es mostra el diagrama TTT a la Figura 66, on no apareix tampoc cap altra fase a més de l'augita, i tots els valors estan per damunt del $\mathbf{9 0 \%}$, incloent el cicle de cocció estàndard.

TTT AUGITA 12

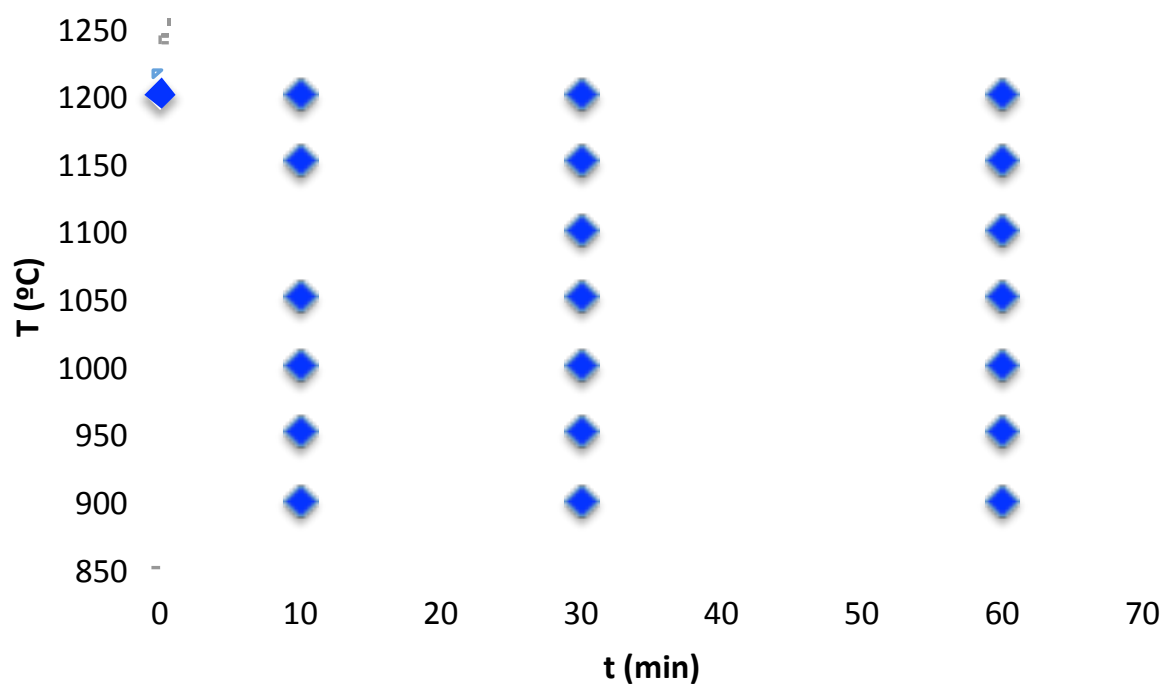

Si $90 \%<$ que la fase formada a la superfície 
Figura 66 Diagrama Transformació-Temperatura-Temps de la fase augita a la superfície de la composició I2.

Si es comparen els resultats del TTT de les superfícies amb els resultats de les anàlisis sobre botons de fusió molturats, a la Taula 30, s'aprecia com s'obtenen valors similars $\mathrm{i}$ amb la mateixa tendència que a la superfície. A la Taula 31, amb valors obtinguts de botons de la composició $\mathbf{I 2}$, es troben resultats similars.

Taula 30 Composició mineralògica dels botons de fusió de la composició I1.

\begin{tabular}{|c|c|c|}
\hline Temperatura $\left({ }^{\circ} \mathbf{C}\right)$ & Temps (min) & Augita \\
\hline 1200 & 0 & 90 \\
\hline 1200 & 10 & 93 \\
\hline 1200 & 60 & 91 \\
\hline 900 & 60 & 94 \\
\hline
\end{tabular}

Taula 31 Composició mineralògica dels botons de fusió de la composició I2.

\begin{tabular}{|c|c|c|}
\hline Temperatura $\left({ }^{\circ} \mathbf{C}\right)$ & Temps (min) & Augita \\
\hline 1200 & 0 & 92 \\
\hline 1200 & 10 & 93 \\
\hline 1200 & 60 & 91 \\
\hline 900 & 60 & 94 \\
\hline
\end{tabular}




\subsubsection{Composició J1.}

En primer lloc es presenta novament les anàlisi químiques en percentatge en pes a la Taula 32, on es manifesta l'alta proporció d'òxid de wolframi a la seva composició. A més, els resultats obtinguts amb microscopi de calefacció s'observen a la Taula 33, on novament s'observa que la temperatura de fusió està molt per damunt de la temperatura de cocció.

Taula 32 Anàlisi química en pes de la composició J1.

\begin{tabular}{|l|l|l|l|l|l|l|l|l|l|l|l|l|}
\hline \multirow{5}{*}{$\mathbf{J 1}$} & $\mathbf{A l}_{2} \mathbf{O}_{3}$ & $\mathbf{S i O}_{2}$ & $\mathbf{N a}_{2} \mathbf{O}$ & $\mathbf{M g O}$ & $\mathbf{K}_{2} \mathbf{O}$ & $\mathbf{C a O}$ & $\mathbf{S r O}$ & $\mathbf{B a O}$ & $\mathbf{Z r O}_{2}$ & $\mathbf{W O}_{3}$ & $\mathbf{P b O}$ & $\mathbf{P P C}$ \\
\cline { 2 - 11 } & 4.24 & 46.9 & 5.18 & 1.14 & 6.14 & 2.69 & 1.36 & 1.98 & 0.28 & 12.8 & 16.9 & 0.24 \\
\cline { 2 - 11 } & $\mathbf{L i}_{2} \mathbf{O}$ & $\mathbf{B}_{2} \mathbf{O}_{3}$ & & & & & & & & & & \\
\cline { 2 - 12 } & $<0,1$ & $<0,25$ & & & & & & & & & & \\
\hline
\end{tabular}

Taula 33 Temperatures característiques de la composició J1, mesurades amb microscopi de calefacció.

\begin{tabular}{|l|c|}
\hline & $\mathbf{J 1}\left({ }^{\mathbf{}} \mathbf{C}\right)$ \\
\hline Sinterització & 705 \\
\hline Reblaniment & 805 \\
\hline Esfera & 978 \\
\hline Mitja esfera & 1069 \\
\hline Fusió & 1284 \\
\hline
\end{tabular}

A l'ATD/TG, a la Figura 67, es veu una cristal·lització tant en la frita molturada (J1) com en el gra de frita $(\mathbf{J 1 g})$ a partir de $\mathbf{9 7 0}^{\circ} \mathbf{C}$, que augmenta de velocitat de cristal·lització a l'arribar a $1200^{\circ} \mathrm{C}$.

La microscòpia de rastreig electrònic de la composició J1 s'ha fet sobre una peça cuita amb un manteniment d'una hora en el refredament a $900^{\circ} \mathrm{C}$. Si s'observa una secció recent, a la Figura 68, es troba per una banda porus de mides diverses, inferiors a $\mathbf{1 0 0}$ micròmetres i cristalls. Apareixen cristalls aciculars, més o menys agrupats, d'una mida al voltant de $\mathbf{5 0}$ micròmetres, amb estructura cristal-lina de wolframat de calci ó wolframat d'òxid de plom.

Si s'observa també la superfície de la mateixa peça, a la Figura 69 es veuen estructures en xarxa que ocupen tota la superfície en línies que es creuen constantment, i que sobreeixen de la superfície, la hidrotungstita. 


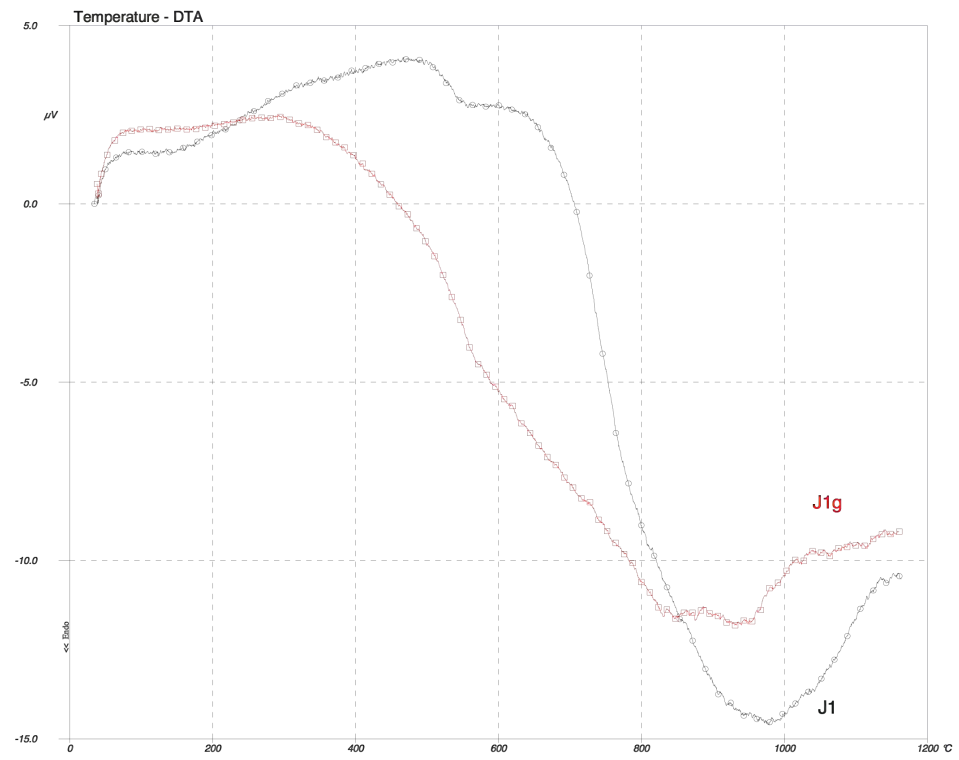

Figura 67 Anàlisis tèrmiques diferencial i termogravimètrica de la composició J1.

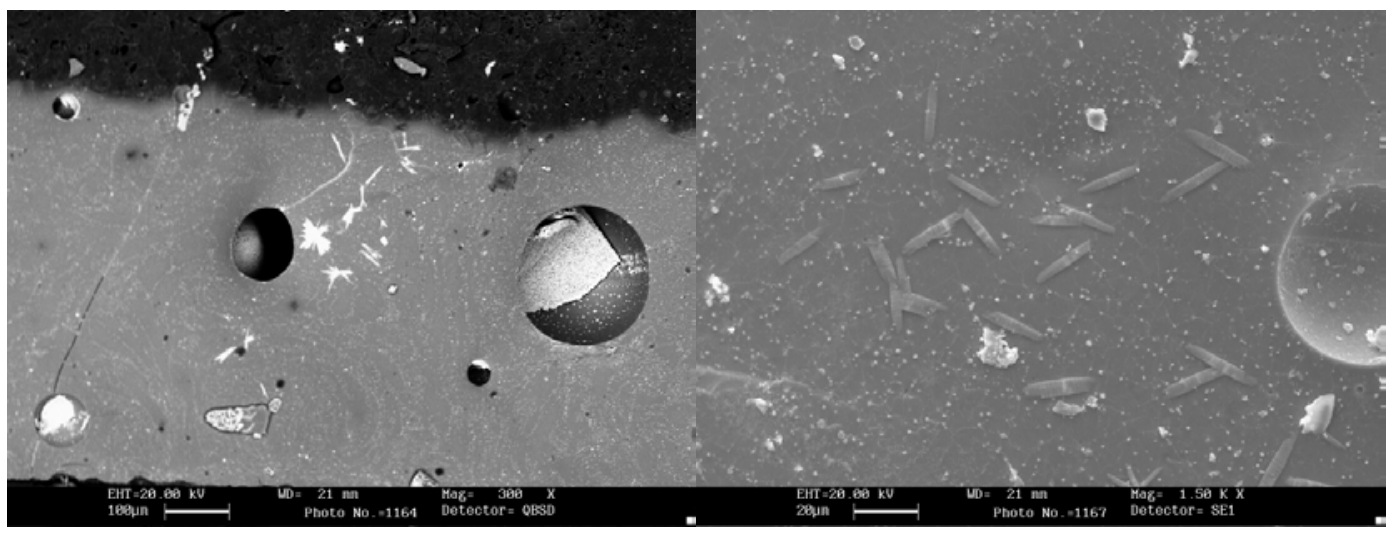

Figura 68 Micrografia de la secció de la composició J1 amb una hora de manteniment a 900C.

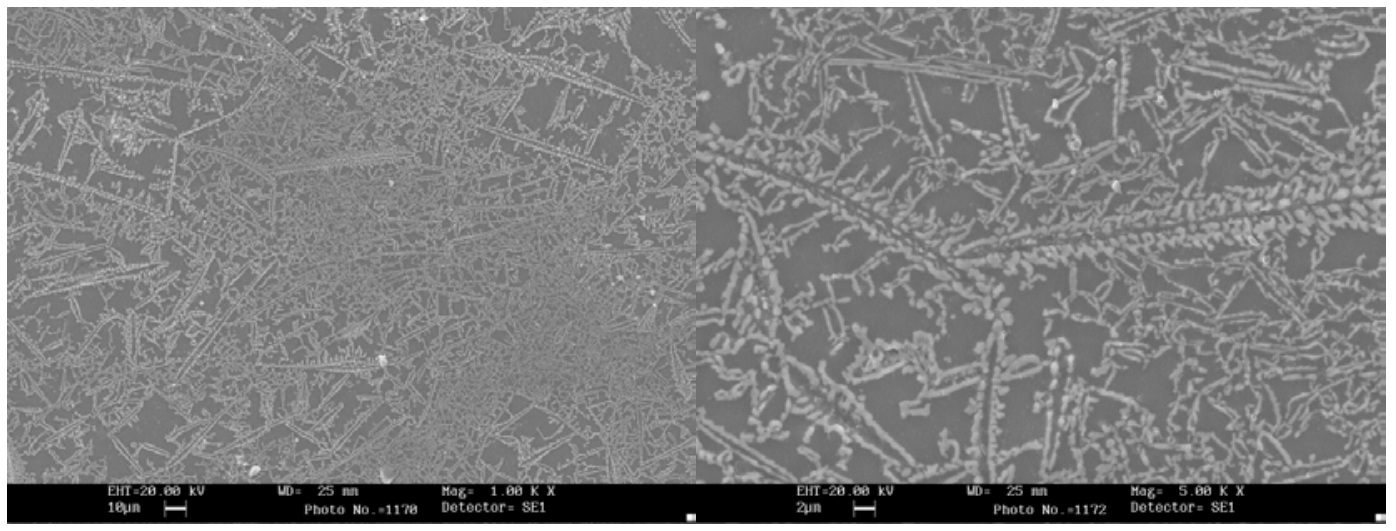

Figura 69 Micrografia de la superfície de la composició J1 amb una hora de manteniment a 900C. 
A la Taula 34, es mostra com el wolframi, a la concentració J1, està concentrat en la fase cristal·lina que forma grans cristalls.

Taula 34 Microanàlisis per dispersió d’energies de raigs $\mathrm{X}$ de la secció de la composició $\mathrm{J} 1$ amb 1 hora de manteniment a $900 \circ \mathrm{C}$.

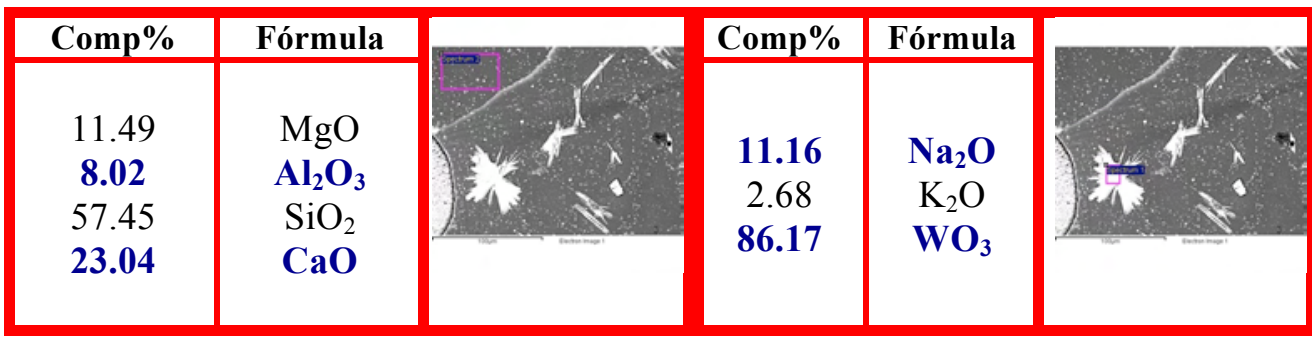

Si es comparen amb les peces a cicle estàndard, es troba que en un cicle industrial els cristalls formats són molt més menuts que en el cicle de $\mathbf{1 h}$, com es pot comprovar en la Figura 70. Tot i que la superfície de les peces es sembla un poc més que l'interior, les agulles formades al cicle estàndard no estan tant connectades com les peces cuites a $\mathbf{1 h}$ de manteniment a $900^{\circ} \mathrm{C}$, com s'observa a la Figura 71.

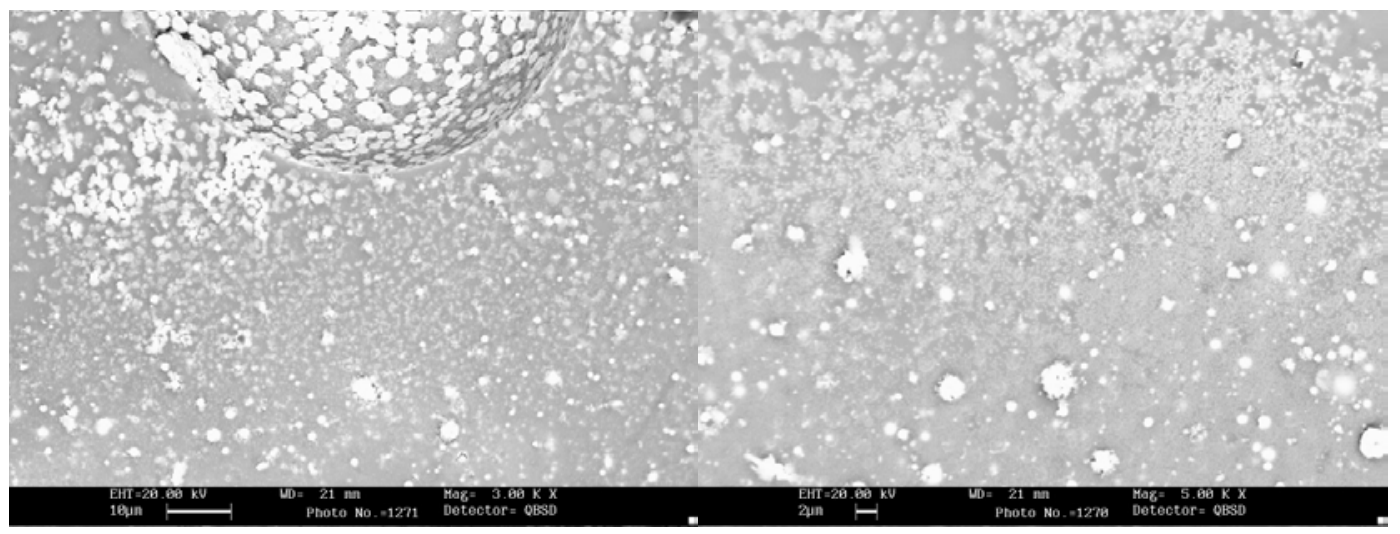

Figura 70 Micrografia de la secció de la composició J1 a cicle de cocció estàndard.

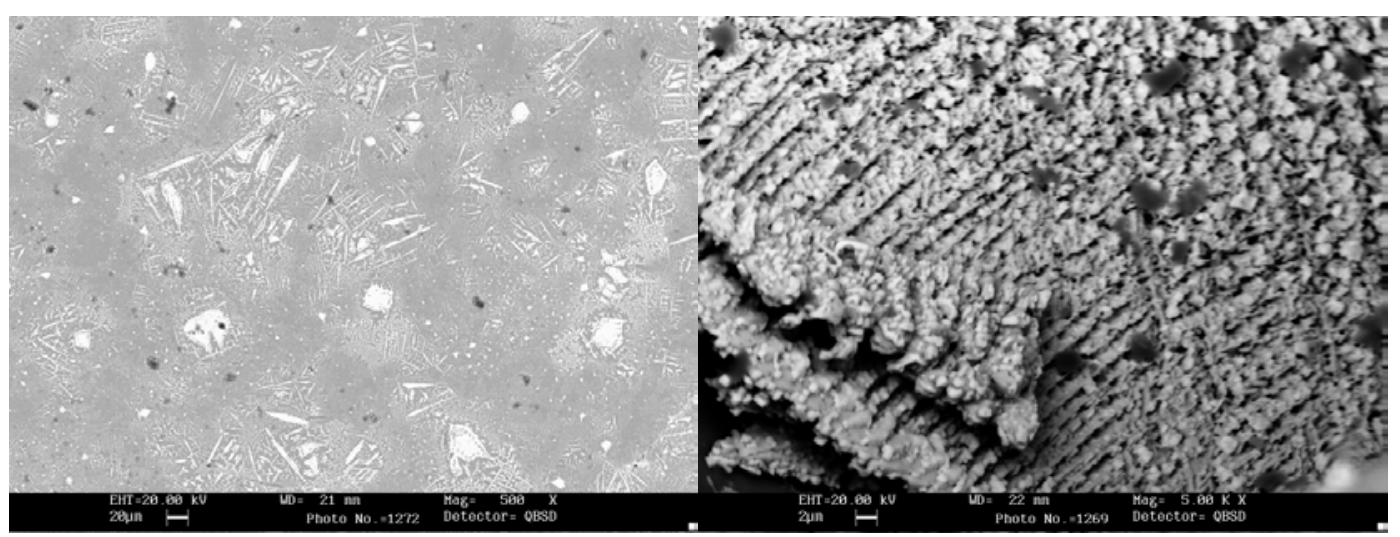

Figura 71 Micrografia de la superfície de la composició J1 a cicle de cocció estàndard. 
L'òxid de wolframi està concentrat a la fase cristal·lina, com s'evidencia a les anàlisis EDX fetes sobre les peces cuites a cicle estàndard, que es presenten a la Taula 35.

A continuació es comproven els resultats obtinguts a les anàlisis per DRX, presentats a la Figura 72. A diferents temperatures de manteniment es troben tres fases diferents. Per una part, la scheelita $\left(\mathbf{C a W O}_{4}\right.$, referenciat com a $\left.\mathbf{S}\right)$ i el wolframat d'òxid de plom (P) apareixen parcialment solapats en els difractogrames, i estan amplament desenvolupats al vidriat tractat durant una hora a $\mathbf{9 0 0}^{\circ} \mathbf{C}$. L'altra fase, l'hidrotungstenita, (H), es desenvolupa més al vidriat tractat tèrmicament amb el cicle estàndard. Cal destacar que la hidrotungstita és una fase hidratada que apareix per envelliment damunt del vidriat a partir dels defectes puntuals de la superfície.

Taula 35 Microanàlisis per dispersió d'energies de raigs $X$ de la secció i la superfície de la composició J1 a cicle de cocció estàndard.

\begin{tabular}{|c|c|c|c|c|c|}
\hline Comp\% & Fórmula & & Comp\% & Fórmula & \\
\hline $\mathbf{6 . 2 4}$ & $\mathrm{Na}_{2} \mathrm{O}$ & & $\mathbf{4 . 3 4}$ & $\mathrm{CaO}$ & \\
1.46 & $\mathrm{MgO}$ & ( & 16.43 & $\mathrm{BaO}$ & \\
$\mathbf{4 . 5 0}$ & $\mathrm{Al}_{2} \mathrm{O}_{3}$ & & $\mathbf{7 0 . 7 1}$ & $\mathrm{WO}_{3}$ & \\
51.83 & $\mathrm{SiO}_{2}$ & & & \\
$\mathbf{4 . 6 4}$ & $\mathrm{K}_{2} \mathrm{O}$ & & & \\
3.17 & $\mathrm{CaO}$ & & & & \\
$\mathbf{1 2 . 0 9}$ & $\mathrm{WO}_{3}$ & & & & \\
16.07 & $\mathrm{PbO}$ & & & & \\
\hline
\end{tabular}

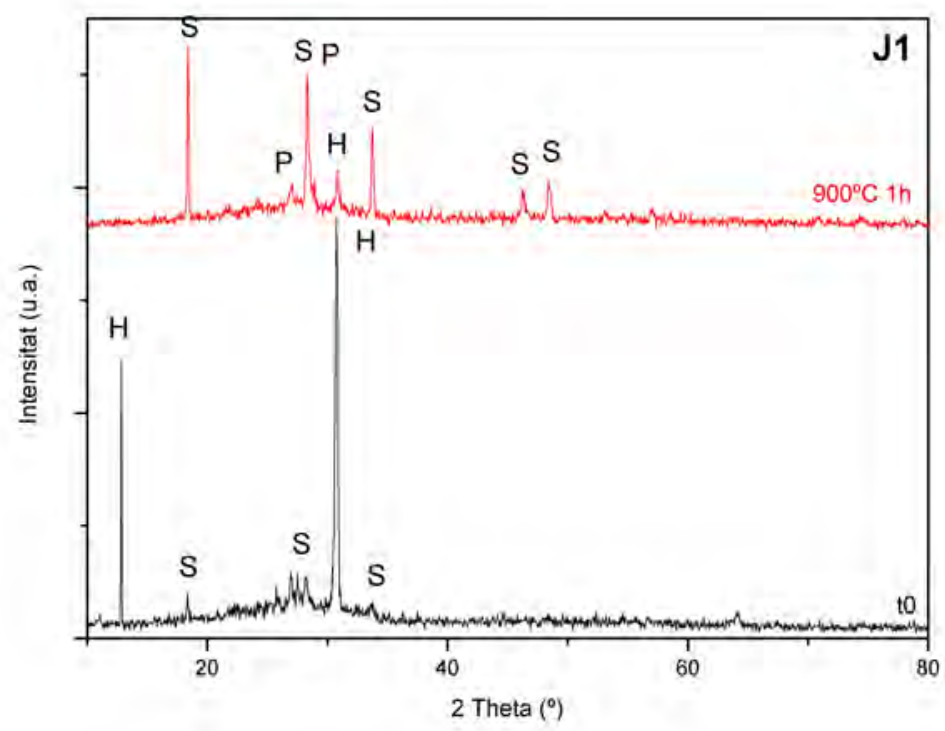

Figura 72 Difractograma de la superfície de la composició J1 amb 1h a 900ㄷ i a cicle de cocció estàndard. 
A continuació, a la Figura 73, es mostra el TTT mesurat a la superfície de les peces de la composició J1 de la fase amb l'estructura de Scheelita, on no es troba correlació entre els temps i manteniment de les peces en el forn i les fases trobades a la superfície. En aquests diagrames, els punts buits representen fase amorfa, els punts grocs representen proporcions entre el 50 i el $\mathbf{8 0 \%}$ de fase i els verds entre el 80 i el $\mathbf{9 0 \%}$.

\section{TTT SCHEELITA J1}

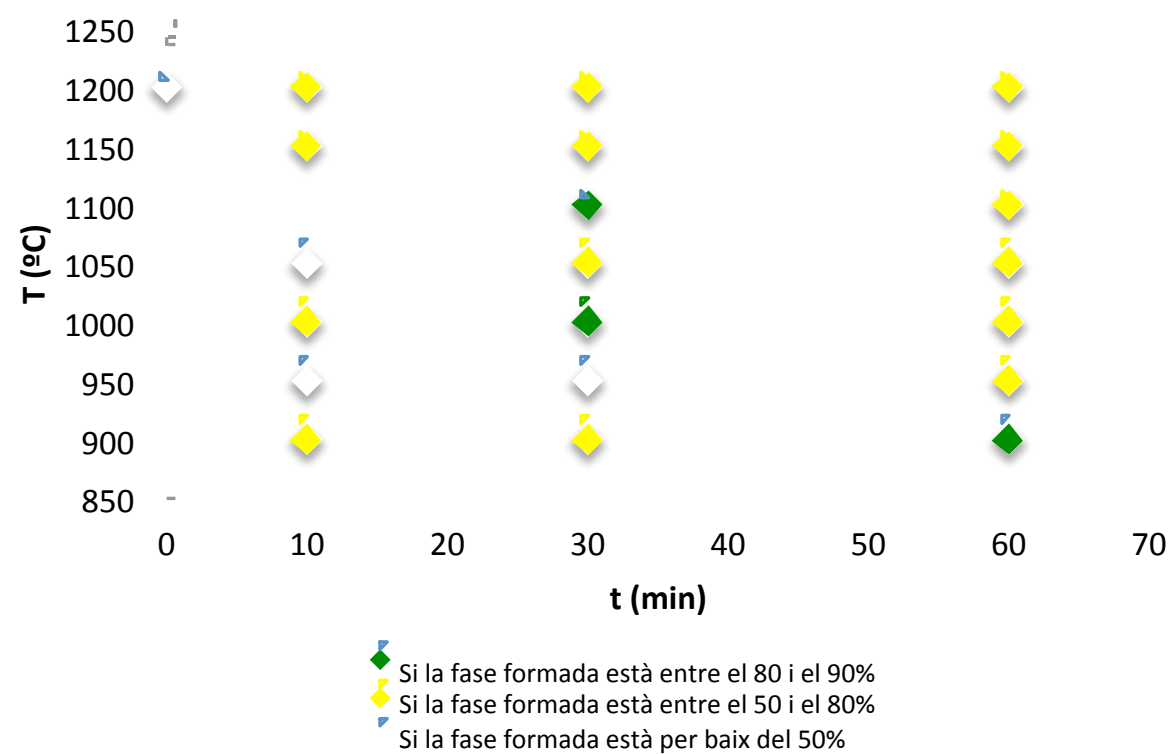

Figura 73 Diagrama Transformació-Temperatura-Temps de la fase scheelita a la superfície de la composició J1.

Per a l'altra fase formada, el wolframat d'òxid de plom $\left(\mathbf{P b}_{\mathbf{2}} \mathbf{O}\left(\mathbf{W} \mathbf{O}_{4}\right)\right)$, cal destacar que apareix esporàdicament als difractogrames de la superfície dels vidriats de la composició $\mathbf{J 1}$, amb ràtios d'intensitat baixos, i és molt complicada de mesurar en condicions de seguretat, ja que hi ha línies solapades amb les corresponents al difractograma de la scheelita.

Finalment, quant a la hidrotungstita, tampoc s'observa una correlació clara, a la Figura 74. Aquest resultat és el que s'esperava, ja que aquesta fase es desenvolupa després de la cocció, en l'absorbir aigua de l'ambient o després dels tractaments preparatoris per a les anàlisis. 


\section{TTT HIDROTUNGSTITA J1}

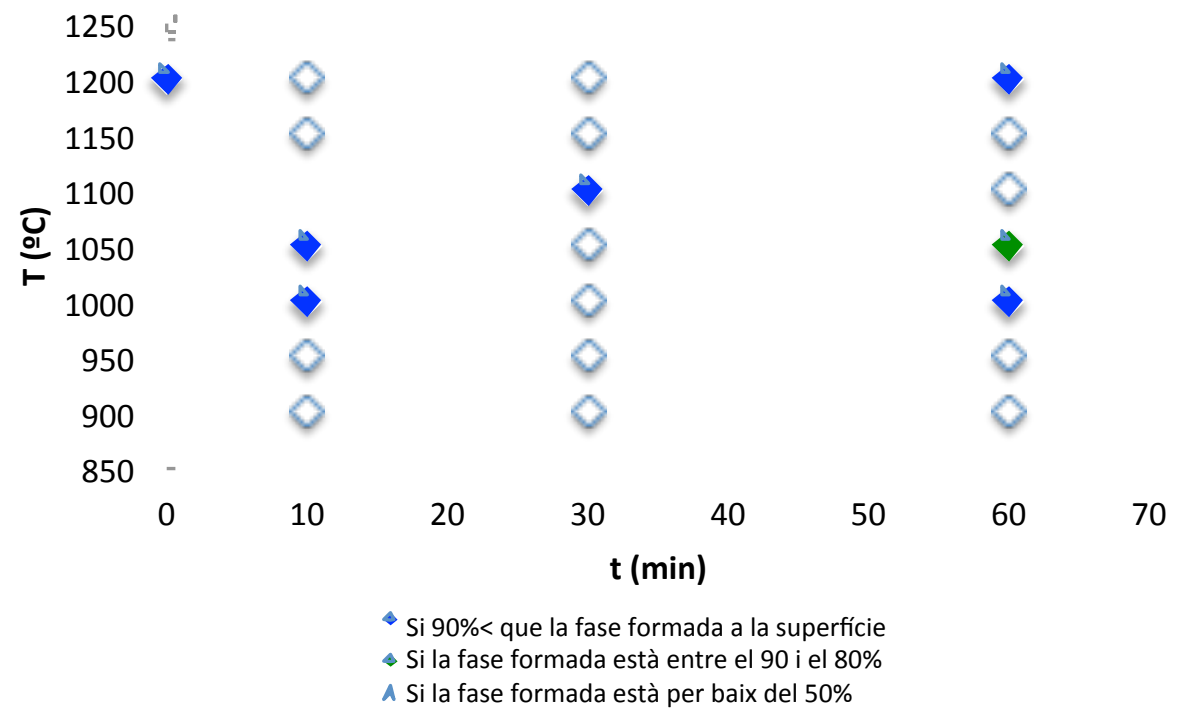

Figura 74 Diagrama Transformació-Temperatura-Temps de la fase hidrotungstita a la superfície de la composició J1.

Un altre problema per a trobar una correlació clara en les altres fases és que la capa formada d'hidrotungstita després de la cocció emmascara les altres fases formades a la superfície, la scheelita i el wolframat d'òxid de plom.

Per acabar es comparen els resultats del TTT de les superfícies dels vidriats de la composició J1 amb els resultats de les anàlisis sobre botons de fusió molturats, a Taula 36, s'aprecia com la correlació no està clara.

Taula 36 Composició mineralògica dels botons de fusió de la composició J1.

\begin{tabular}{|c|c|c|c|c|}
\hline Temperatura $\left({ }^{\circ} \mathbf{C}\right)$ & Temps (min) & Scheelita & $\begin{array}{c}\text { Wolframat de } \\
\text { plom }\end{array}$ & Hidrotungstita \\
\hline 1200 & 0 & 0 & 0 & 0 \\
\hline 1200 & 10 & 0 & 0 & 98 \\
\hline 1200 & 60 & 60 & 96 & 0 \\
\hline 900 & 60 & 0 & 62 & 0 \\
\hline
\end{tabular}

A la vista d'aquests valors, s'intueix que la scheelita es desenvolupa més a la superfície i el wolframat de plom a l'interior, a llargs temps de manteniment. També s'observa com la hidrotungstita es genera massivament si les condicions són favorables o no es detecta, ni en quantitats baixes. 


\subsubsection{Composició J3.}

Aquesta composició es caracteritza perquè conté ceri i wolframi, com s'observa a la Taula 37, on es presenten els resultats obtinguts en percentatge en pes de les anàlisis de FRX. Els resultats obtinguts amb microscopi de calefacció, on s'indica que aquesta composició presenta una temperatura de fusió molt per baix de la temperatura de cocció, com la J1, s'observen a la Taula 38.

Taula 37 Anàlisi química en pes de la composició J3.

\begin{tabular}{|l|l|l|l|l|l|l|l|l|l|l|l|l|}
\hline \multirow{5}{*}{$\mathbf{J 3}$} & $\mathrm{Al}_{2} \mathrm{O}_{3}$ & $\mathbf{S i O}_{2}$ & $\mathrm{Na}_{2} \mathrm{O}$ & $\mathbf{M g O}$ & $\mathrm{K}_{2} \mathrm{O}$ & $\mathbf{C a O}$ & $\mathrm{SrO}$ & $\mathbf{B a O}$ & $\mathrm{ZrO}_{2}$ & $\mathbf{W O}_{3}$ & $\mathrm{PbO}$ & $\mathbf{P P C}$ \\
\cline { 2 - 12 } & 4.65 & $\mathbf{4 5 . 1}$ & 5.36 & $\mathbf{1 . 1 2}$ & 6.37 & $\mathbf{2 . 5 7}$ & 1.31 & $\mathbf{1 . 9 6}$ & 0.29 & $\mathbf{7 . 0 2}$ & 16.6 & $\mathbf{0 . 0 5}$ \\
\cline { 2 - 12 } & $\mathbf{V}_{\mathbf{2}} \mathbf{O}_{\mathbf{5}}$ & $\mathrm{CeO}_{2}$ & & & & & & & & & & \\
\cline { 2 - 12 } & $\mathbf{1 . 1 3}$ & 6.19 & & & & & & & & & & \\
\hline
\end{tabular}

Taula 38 Temperatures característiques de la composició J3 mesurades amb microscopi de calefacció.

\begin{tabular}{|l|c|}
\hline & J3 $\left(^{\circ} \mathbf{C}\right)$ \\
\hline Sinterització & 675 \\
\hline Reblaniment & 707 \\
\hline Mitja esfera & 1011 \\
\hline Fusió & 1123 \\
\hline
\end{tabular}

A la Figura 75, a l'ATD-TG sols s'observa una cristal·lització, que comença a partir dels $\mathbf{9 0 0}^{\circ} \mathbf{C}$ simultàniament a la frita molturada $(\mathbf{J 3})$ i el gra de frita sense molturar $(\mathbf{J 3 g})$, que indica que la cristal·lització és volumètrica. 


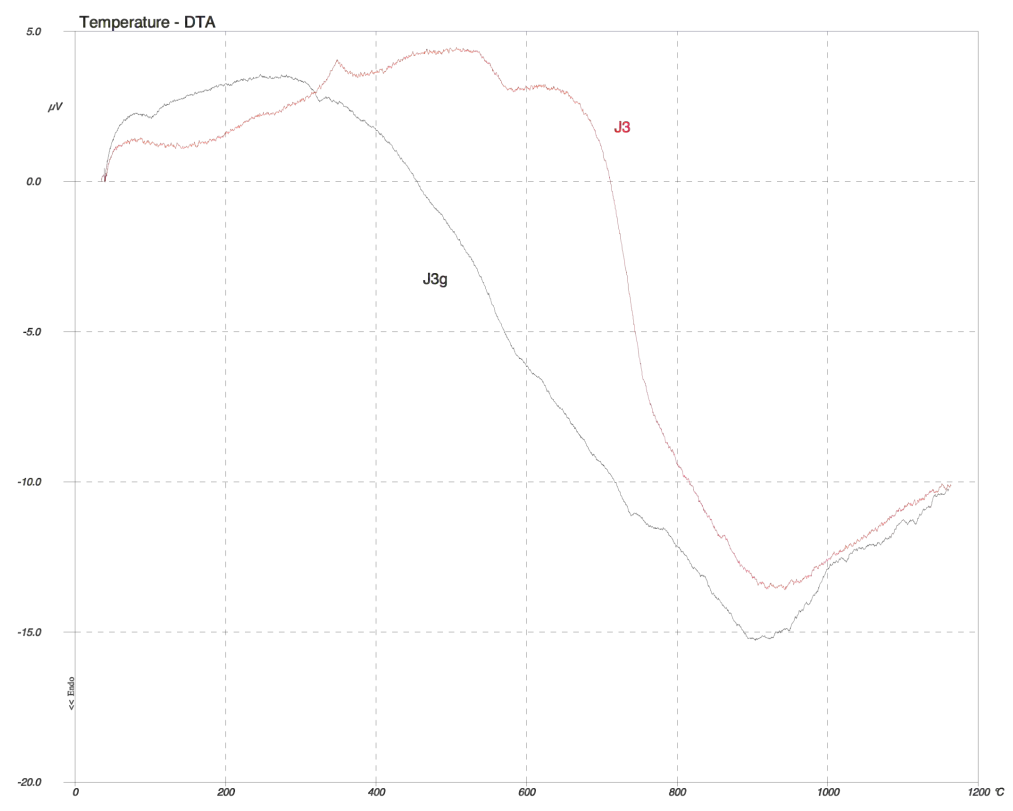

Figura 75 Anàlisis tèrmiques diferencial i termogravimètrica de la composició J3.

Les micrografies de la composició J3 s'han fet sobre una peça cuita amb un temps de manteniment d'una hora durant l'etapa de refredament a $\mathbf{9 0 0}^{\circ} \mathbf{C}$. Quan s'observa una secció recent, es troben cristalls molt menuts al sí de la fase vítria, rica en plom, a la Figura 76. A la superfície, com es pot veure a la Figura 77, hi ha més cristalls, de manera que es troba l'òxid de ceri concentrat en zones menudes.

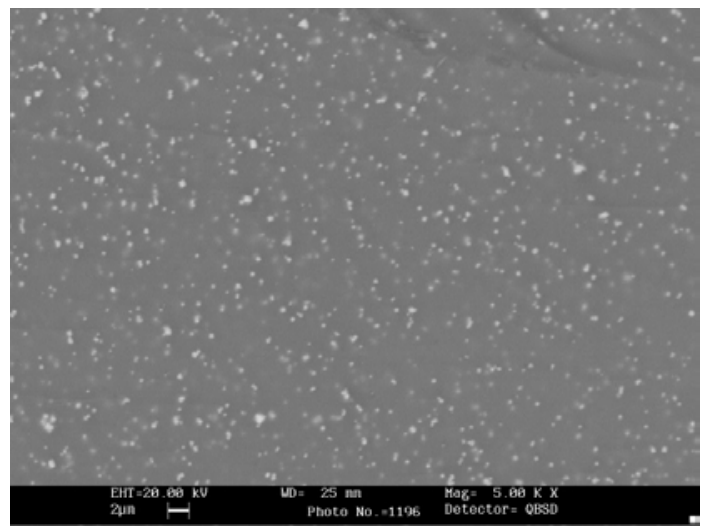

Figura 76 Micrografia de la secció de la composició J3 amb una hora de manteniment a 900C. 


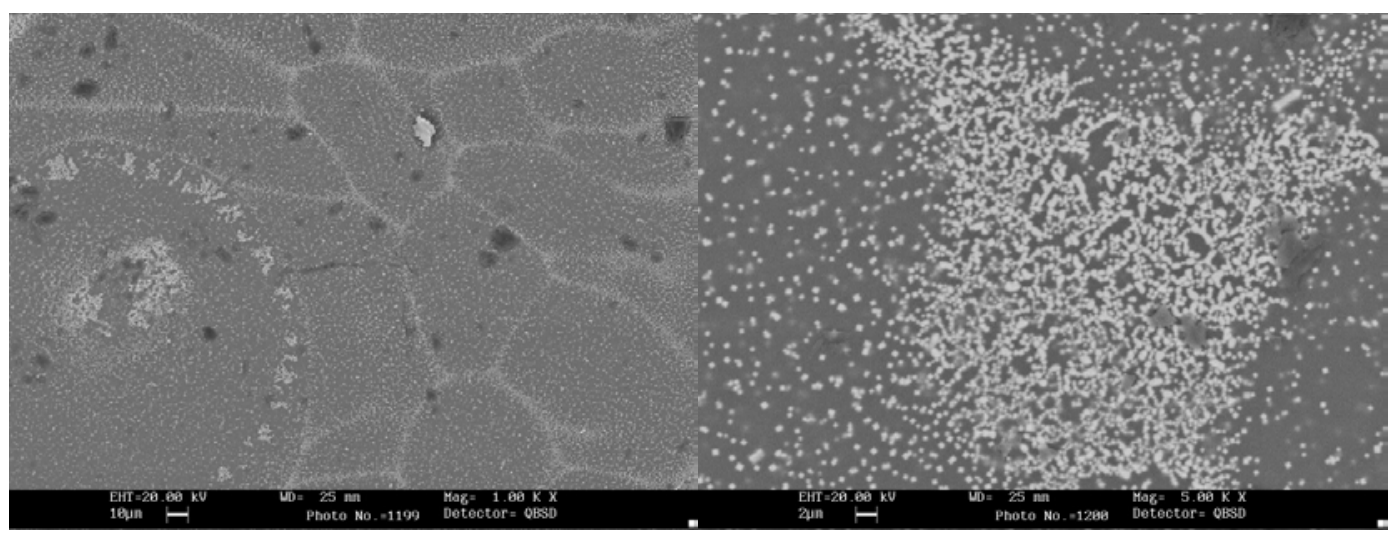

Figura 77 Micrografia de la superfície de la composició J3 amb una hora de manteniment a 900ㄷ․

A les anàlisis semiquantitatives fetes per EDX, a la Taula 39, es veu clarament com l’òxid de ceri està concentrat a la fase cristal·lina $\mathrm{i}$ la fase vítria és més rica en sílice $\mathrm{i}$ plom.

Taula 39 Microanàlisis per dispersió d'energies de raigs X de la fase vítria i cristal-lina de la composició J3 amb $1 \mathrm{~h}$ de manteniment a $900 \circ \mathrm{C}$.

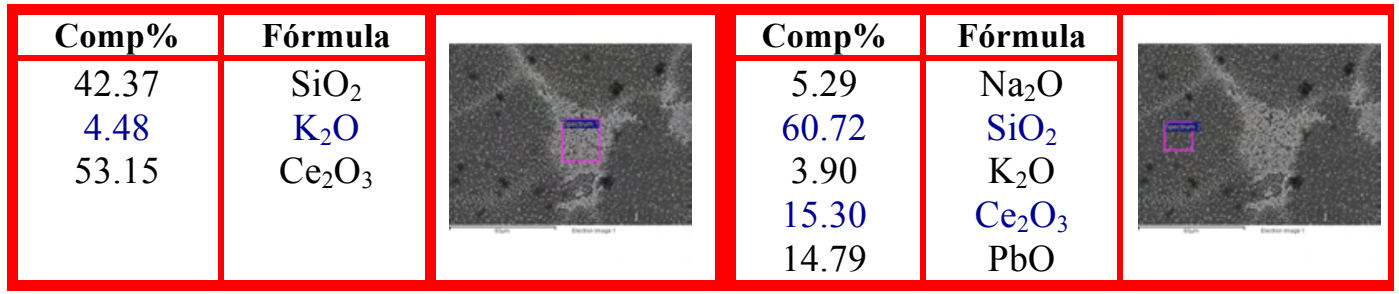

Quan es comparen aquestes anàlisis amb les peces cuites a cicle estàndard, a la secció trobem un aspecte molt similar a les que han estat $1 \mathrm{~h}$ a $900^{\circ} \mathrm{C}$, com mostra la Figura 78, $\mathrm{i}$ si s'observen les imatges de la superfície, també es troben similituds, com es mostra a la Figura 79:

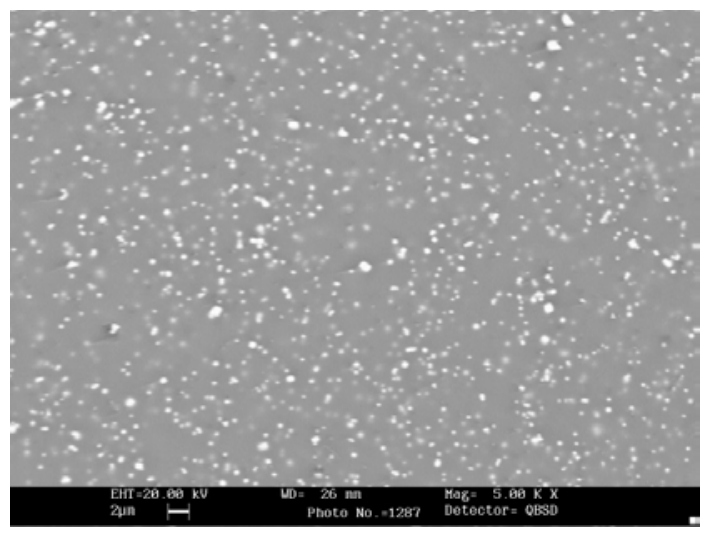

Figura 78 Micrografia de la secció de la composició J3 a cicle de cocció estàndard. 


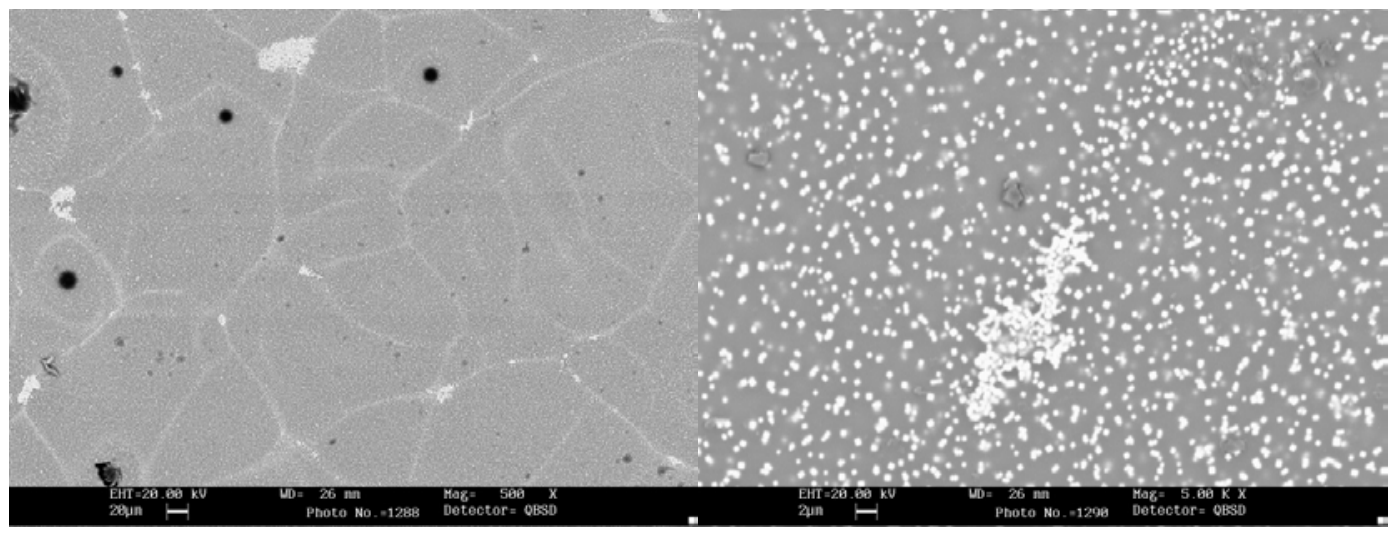

Figura 79 Micrografia de la superfície de la composició J3 a cicle de cocció estàndard.

Les anàlisis EDX que es troben, tant a la secció com a la superfície són les que apareixen a la Taula 40, on es veu novament la concentració de l'òxid de ceri a la fase cristal·lina.

Taula 40 Microanàlisis per dispersió d'energies de raigs $X$ de la composició J3 a cicle de cocció estàndard.

\begin{tabular}{|c|c|c|c|c|}
\hline Comp\% & Fórmula & Comp\% & Fórmula \\
\hline 5.66 & $\mathrm{Na}_{2} \mathrm{O}$ & & \\
1.55 & $\mathrm{MgO}$ & 3.24 & $\mathrm{Na}_{2} \mathrm{O}$ \\
4.85 & $\mathrm{Al}_{2} \mathrm{O}_{3}$ & 4.18 & $\mathrm{Al}_{2} \mathrm{O}_{3}$ & \\
53.08 & $\mathrm{SiO}_{2}$ & 37.03 & $\mathrm{SiO}_{2}$ \\
3.86 & $\mathrm{~K}_{2} \mathrm{O}$ & 3.25 & $\mathrm{~K}_{2} \mathrm{O}$ \\
2.86 & $\mathrm{CaO}$ & 1.73 & $\mathrm{CaO}$ \\
2.45 & $\mathrm{BaO}$ & 40.28 & $\mathrm{Ce}_{2} \mathrm{O}_{3}$ \\
7.47 & $\mathrm{Ce}$ & 10.28 & $\mathrm{PbO}_{3}$ \\
18.21 & $\mathrm{PbO}$ & & \\
\hline
\end{tabular}

Si s'observa els DRX, s'identifica clarament tots els pics de la cerianita cristal·litzada en els dos diagrames, pot ser més orientada en el cas del cicle més curt, l'estàndard, a la Figura 80: 


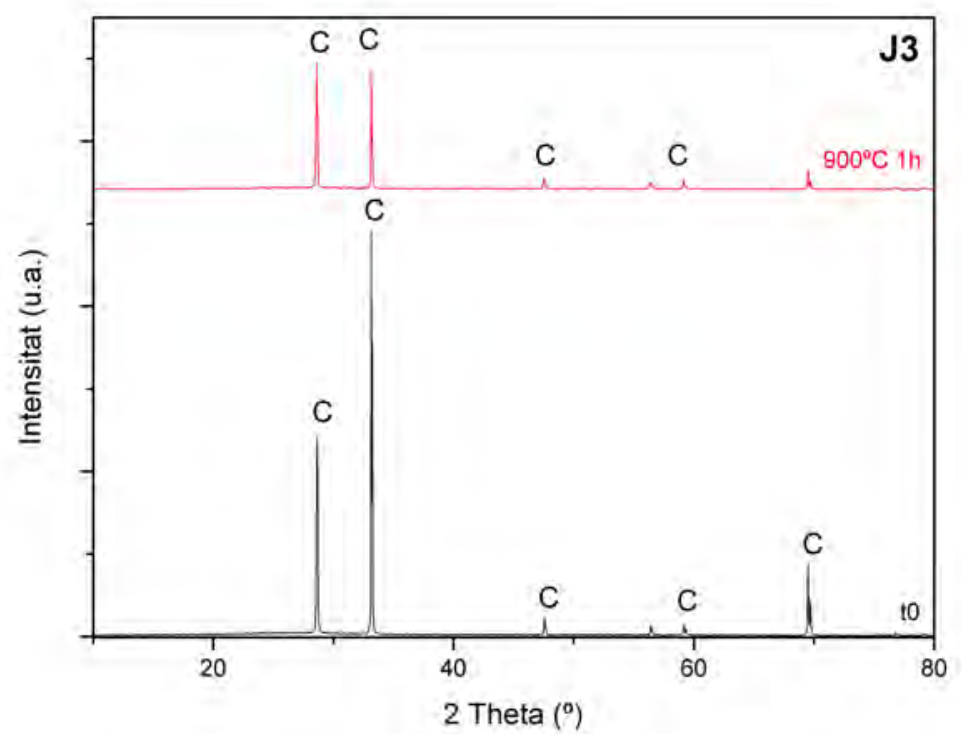

Figura 80 Difractograma de la superfície de la composició J3 amb 1h a 900ㄷ $\mathrm{i}$ a cicle de cocció estàndard.

Al diagrama TTT de la fase cerianita a la superfície de la peça es comprova l'alta estabilitat de la fase a la composició J3, a la Figura 81.

\section{TTT CERIANITA J3}

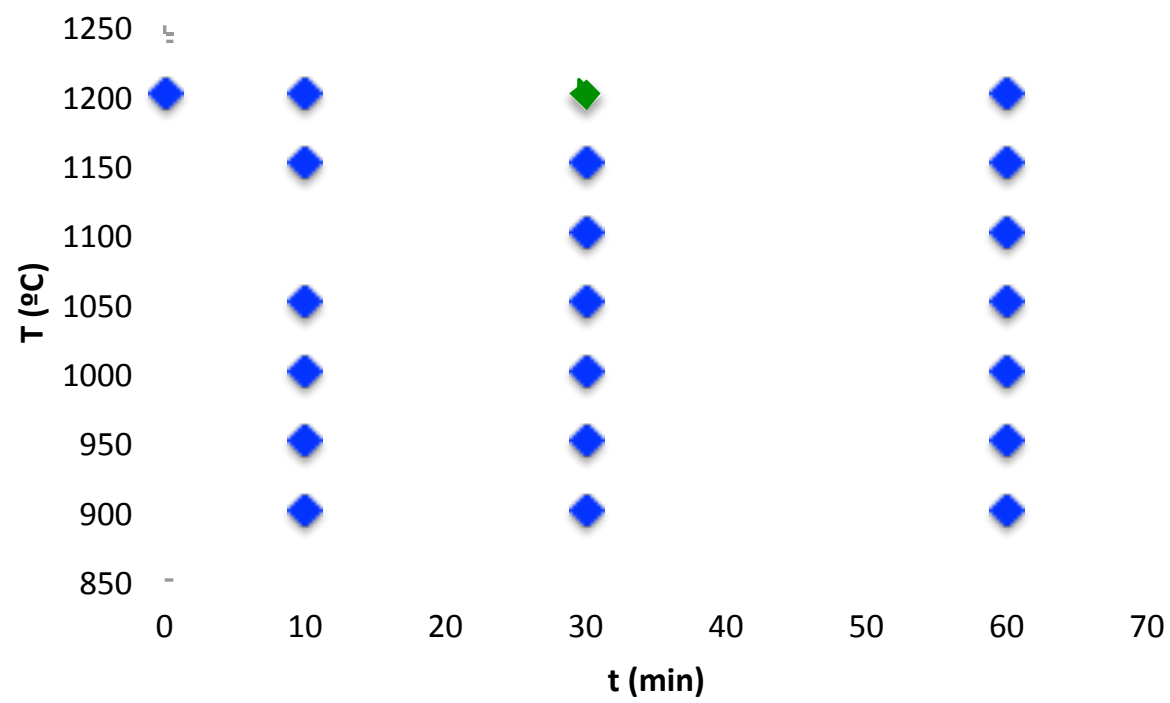

Si $90 \%<$ que la fase formada a la superfície Si la fase formada està entre el 90 i el $80 \%$

Figura 81 Diagrama Transformació-Temperatura-Temps de la fase cerianita a la superfície de la composició J3. 
Es fan assajos amb botons de fusió a diferents temperatures, i es conclou que els valors assajats són sensiblement inferiors als calculats per a la superfície dels vidriats, tal i com es pot comprovar a la Taula 41. Aquest resultat concorda amb les imatges SEM, on s'han apreciat clarament amuntegaments de cristalls de cerianita a la superfície.

Taula 41 Composició mineralògica dels botons de fusió de la composició J3.

\begin{tabular}{|c|c|c|}
\hline Temperatura $\left({ }^{\mathbf{0}} \mathbf{C}\right)$ & Temps (min) & Cerianita \\
\hline 1200 & 0 & 92,6 \\
\hline 1200 & 10 & 85,1 \\
\hline 900 & 60 & 78,3 \\
\hline
\end{tabular}




\subsection{Comparativa entre les peces de composicions fritades i no fritades en forn mufla de laboratori.}

Amb motiu de poder estudiar la potencialitat de les composicions no fritades, es preparen mostres noves de composicions i es preparen mostres sense fritar, crues (anomenades C). Es molturen per a caracteritzar la pols, químicament i mineralògica, i es preparen peces esmaltades per analitzar mineralògicament les fases formades durant la cocció. Les peces es couen al cicle de cocció estàndard. Cal destacar que totes les composicions contenen matèries primeres que desgasifiquen durant la cocció, excepte les composicions A1, J1 i J3.

\subsubsection{Composició A1.}

En primer lloc, es presenta la comparativa de les anàlisis químiques del material sense coure, en pols, entre la nova frita preparada i la composició en cru, a la Taula 42. Es comprova com la composició no varia massa.

Taula 42 Anàlisis químiques de la composició A1 crua (A1C) i fritada (A1).

\begin{tabular}{|l|l|l|l|l|l|l|l|l|l|l|l|}
\hline \% Pes & $\mathrm{Al}_{2} \mathrm{O}_{3}$ & $\mathbf{S i O}_{\mathbf{2}}$ & $\mathrm{Na}_{2} \mathrm{O}$ & $\mathbf{K}_{\mathbf{2}} \mathbf{O}$ & $\mathrm{MgO}$ & $\mathbf{C a O}$ & $\mathrm{TiO}_{2}$ & $\mathbf{F e}_{2} \mathbf{O}_{3}$ & $\mathrm{Li}_{2} \mathrm{O}$ & $\mathbf{B}_{\mathbf{2}} \mathbf{O}_{\mathbf{3}}$ & $\mathrm{PPC}$ \\
\hline $\mathbf{A 1}$ & 14,2 & $\mathbf{5 5 , 9}$ & 6.68 & $\mathbf{0 . 8 0}$ & 2.16 & $\mathbf{6 . 9 2}$ & 0.45 & $\mathbf{1 0 , 9}$ & $<0,1$ & $<\mathbf{0 , 2 5}$ & +0.87 \\
\hline $\mathbf{A 1 C}$ & 12,5 & $\mathbf{5 5 , 5}$ & 7,08 & $\mathbf{0 . 7 6}$ & 2.20 & $\mathbf{7 , 1 6}$ & 0.43 & $\mathbf{1 1 . 0}$ & $<0,1$ & $<\mathbf{0 , 2 5}$ & +0.29 \\
\hline
\end{tabular}

La peça esmaltada amb frita presenta partícules menudes d'hematites a la secció i a la superfície. En canvi, si s'observa les micrografies de les peces esmaltades amb residus sense fritar es troben menys cristalls tant a la secció, Figura 82, com a la superfície a la Figura 83.

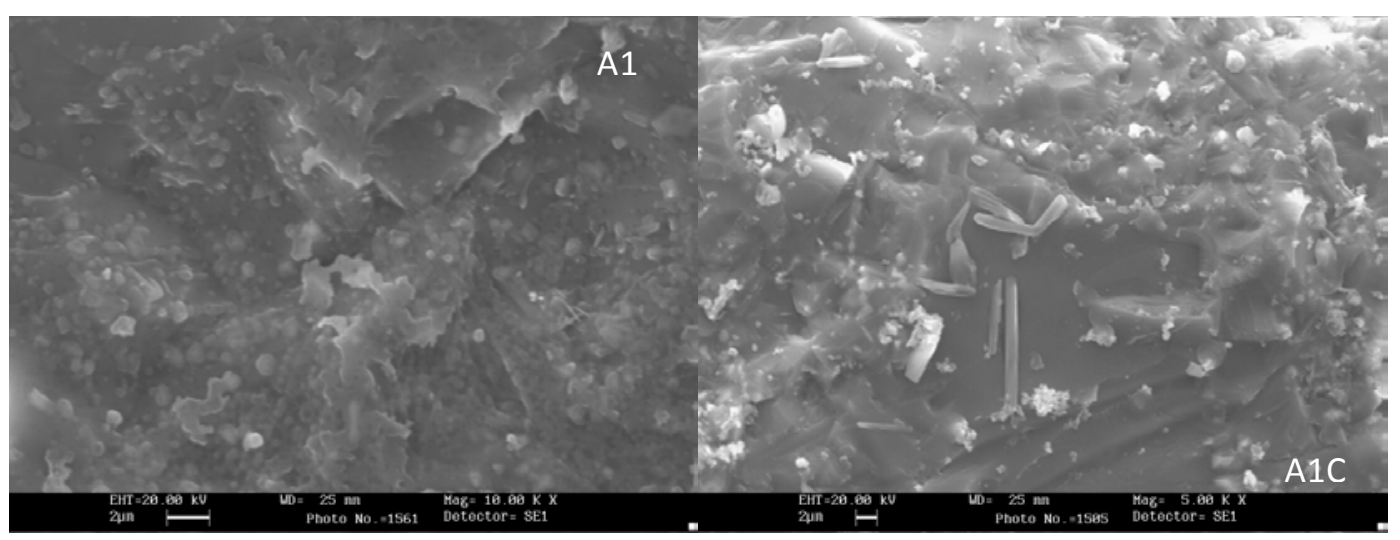

Figura 82 Micrografies de la secció les composicions A1 i A1C a cicle estàndard. 


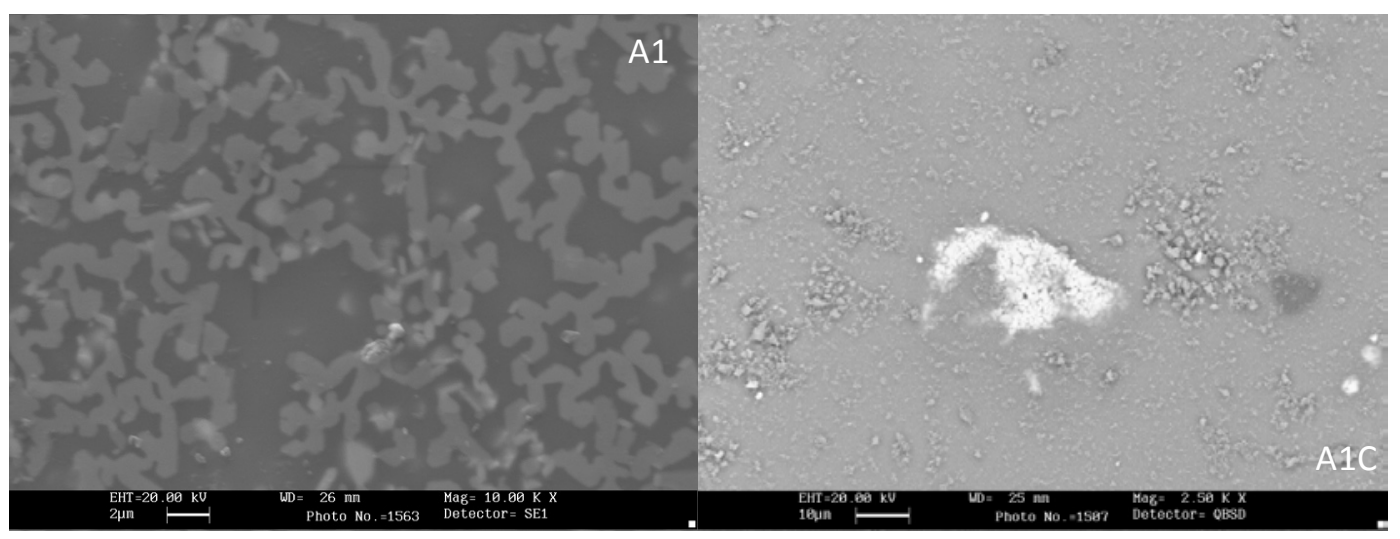

Figura 83 Micrografies de la superfície de les composicions A1 i A1C.

Les anàlisis per DRX obtingudes per aquestes peces són també molt diferents, com s'aprecia a la Figura 84, amb molta més cristal·lització a la peça esmaltada amb frita que amb el material cru:

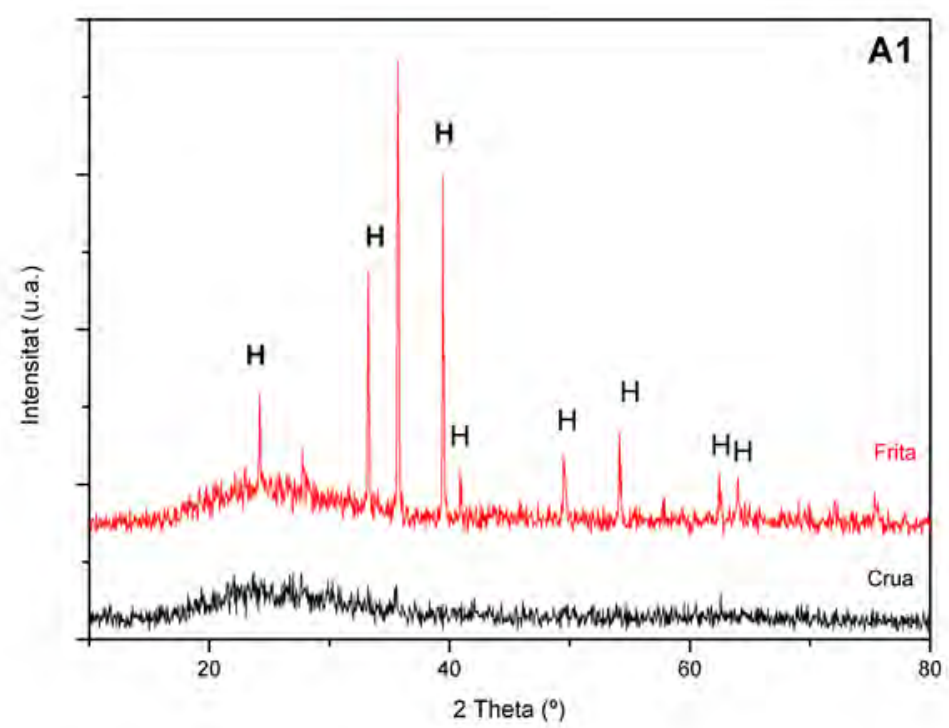

Figura 84 Difractograma de la superfície de les composicions A1 i A1C a cicle de cocció estàndard. 


\subsubsection{Composició B1.}

Es mostren en primer lloc les anàlisis químiques de les composicions B1 i B1C, a la Taula 43, on no s'aprecien grans diferències de composició, tenint en conter les pèrdues per calcinació degudes al contingut en creta:

Taula 43 Anàlisis químiques de la composició B1 crua (B1C) i fritada (B1).

\begin{tabular}{|l|c|c|c|c|c|c|c|c|c|c|c|}
\hline \% Pes & $\mathrm{Al}_{2} \mathrm{O}_{3}$ & $\mathbf{S i O}_{2}$ & $\mathrm{Na}_{2} \mathrm{O}$ & $\mathbf{K}_{\mathbf{2}} \mathbf{O}$ & $\mathrm{MgO}$ & $\mathbf{C a O}$ & $\mathrm{TiO}_{2}$ & $\mathbf{F e}_{2} \mathbf{O}_{3}$ & $\mathrm{Li}_{2} \mathrm{O}$ & $\mathbf{B}_{2} \mathbf{O}_{3}$ & $\mathrm{PPC}$ \\
\hline $\mathbf{B 1}$ & 5,5 & $\mathbf{5 5 , 5}$ & 5,1 & $\mathbf{2 , 1}$ & - & $\mathbf{1 3 , 1}$ & - & $\mathbf{9 , 8}$ & $<0,1$ & $\mathbf{8 , 5}$ & 0,8 \\
\hline $\mathbf{B 1 C}$ & 4,9 & $\mathbf{5 2 , 5}$ & 4,8 & $\mathbf{1 , 8}$ & - & $\mathbf{1 1 , 5}$ & - & $\mathbf{9 , 7}$ & $<0,1$ & $\mathbf{7 , 5}$ & 7,2 \\
\hline
\end{tabular}

La peça esmaltada amb frita presenta cristalls menuts a la secció. En canvi, si s'observen les micrografies de les peces esmaltades amb residus sense fritar, es troben menys partícules tant a la secció, a la Figura 85, com a la superfície, a la Figura 86.

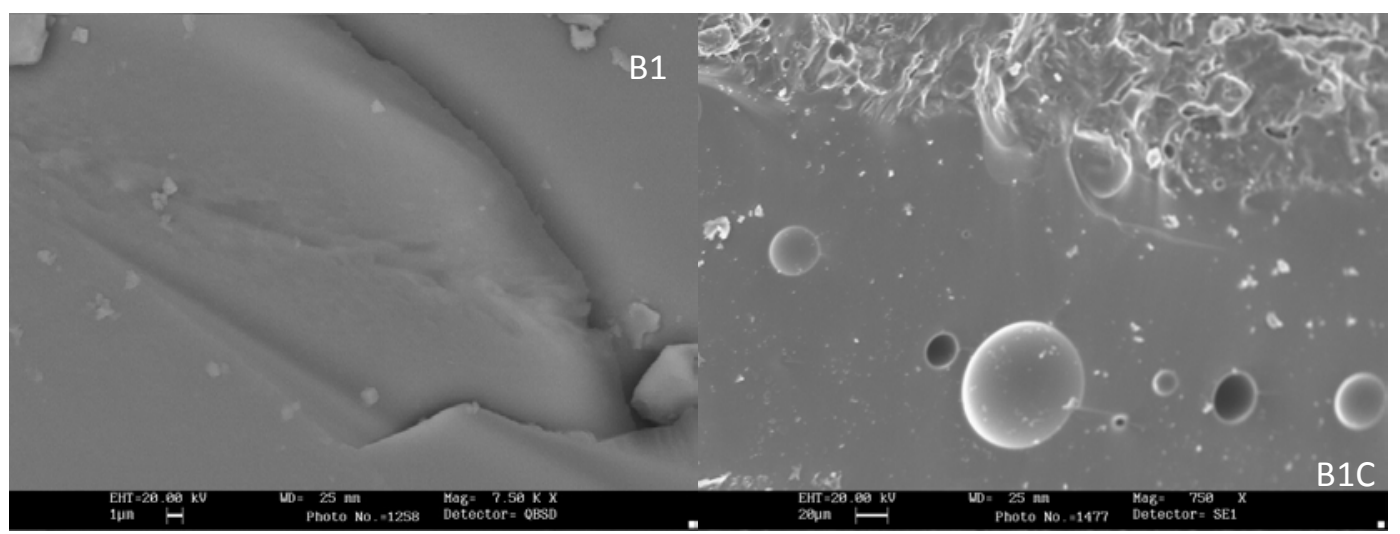

Figura 85 Micrografies de la secció de la composició B1 crua (B1C) i fritada (B1).

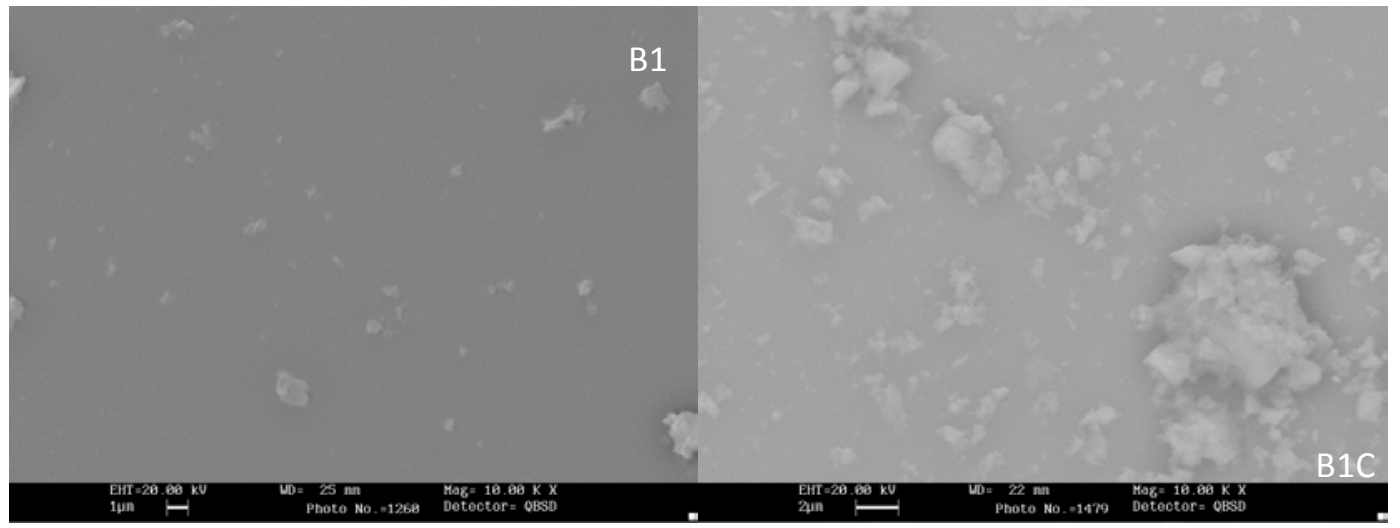

Figura 86 Micrografies de la superfície de les composicions B1 i B1C. 
Si es comprova l'estructura formada a la superfície de la peça, a la Figura 87, es veu com el esmalt cru, sense fritar, no aconsegueix cristal·litzar cap estructura durant el cicle de cocció, mentre que la frita, cristal·litza borat de sodi (B) a la seva superfície.

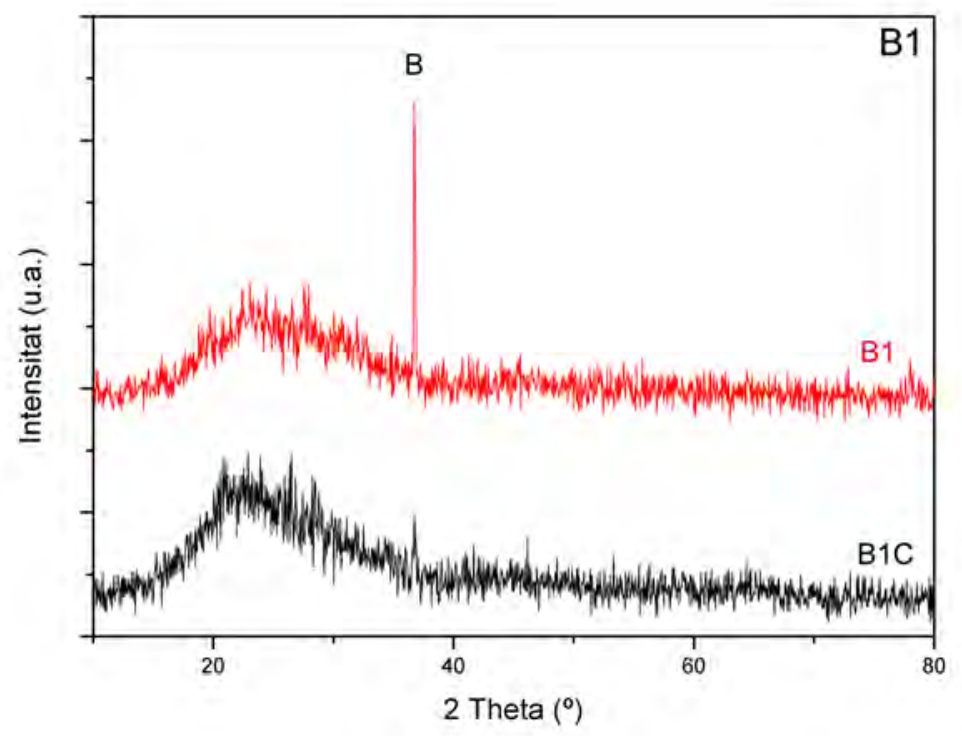

Figura 87 Difractograma de la superfície de les composicions B1 i B1C a cicle de cocció estàndard. 


\subsubsection{Composició E1.}

A continuació es poden veure les anàlisis químiques de les composicions E1, fritada, i E1C, crua, a la Taula 44, on es troben valors relativament similars si es té en compte les pèrdues per calcinació degudes a les desgasificacions del carbonat de liti i del talc:

Taula 44 Anàlisis químiques de la composició E1 crua (E1C) i fritada (E1).

\begin{tabular}{|l|l|l|l|l|l|l|l|l|l|l|l|}
\hline \% Pes & $\mathrm{Al}_{2} \mathrm{O}_{3}$ & $\mathbf{S i O}_{\mathbf{2}}$ & $\mathrm{Na}_{2} \mathrm{O}$ & $\mathbf{M g O}$ & $\mathrm{K}_{2} \mathrm{O}$ & $\mathbf{C a O}$ & $\mathrm{TiO}_{2}$ & $\mathbf{F e}_{2} \mathbf{O}_{\mathbf{3}}$ & $\mathrm{Li}_{2} \mathrm{O}$ & $\mathbf{B}_{\mathbf{2}} \mathbf{O}_{3}$ & $\mathrm{PPC}$ \\
\hline E1 & 25,2 & $\mathbf{5 0 , 4}$ & 1,6 & $\mathbf{1 , 7}$ & 3,4 & $\mathbf{3 , 4}$ & 0,6 & $\mathbf{8 , 4}$ & 3,5 & $\mathbf{2 , 4}$ & 0,9 \\
\hline E1C & 21,1 & $\mathbf{4 5 , 0}$ & 2,6 & $\mathbf{1 , 8}$ & 0,9 & $\mathbf{3 , 7}$ & 0,6 & $\mathbf{9 , 2}$ & 3,4 & $\mathbf{2 , 3}$ & 9,3 \\
\hline
\end{tabular}

La peça esmaltada amb frita tant a penes presenta cristalls menuts a la secció. En canvi, si s'observen les micrografies de les peces esmaltades amb residus sense fritar, es troben més partícules tant a la secció, a la Figura 88, com a la superfície, a la Figura 89.

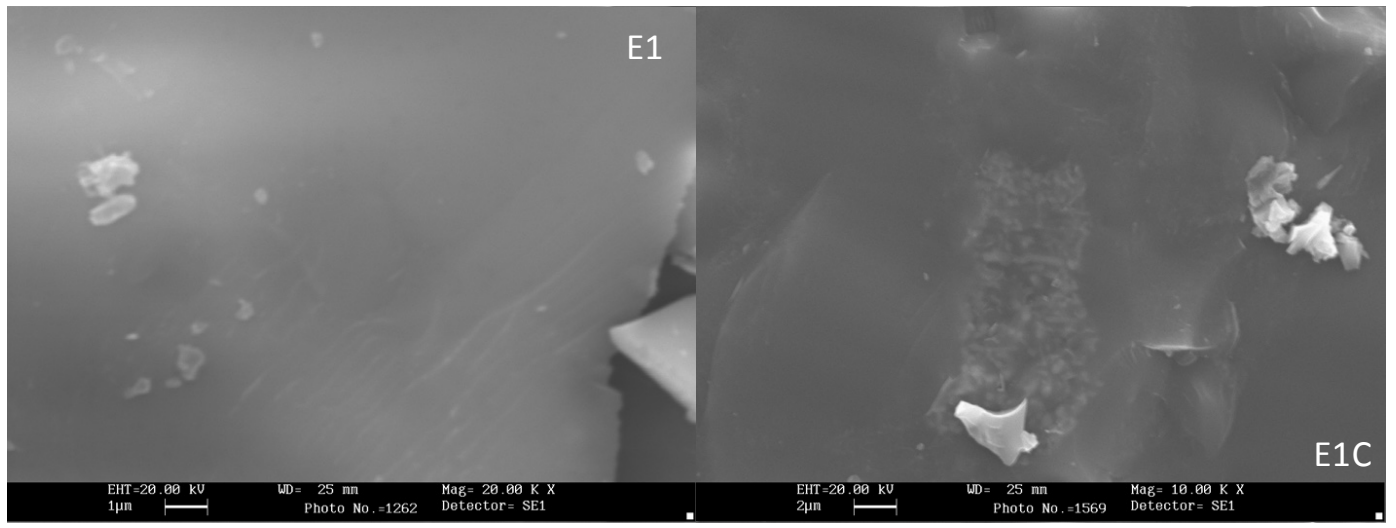

Figura 88 Micrografies de la secció de les composicions E1 i E1C.

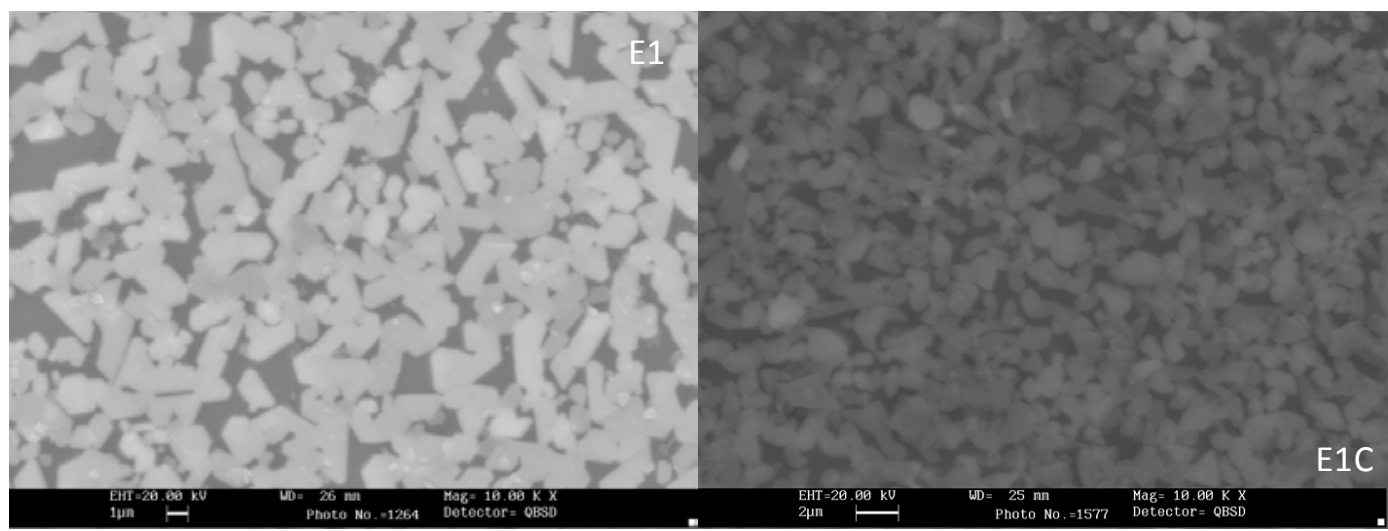

Figura 89 Micrografies de la superfície de les composicions E1 i E1C. 
En estudiar el difractograma de la superfície de les peces, comparant entre els resultats obtinguts de la composició fritada prèviament i de la composició crua, s'observa a la Figura 90 molta més cristal·lització en la peça crua que en la fritada.

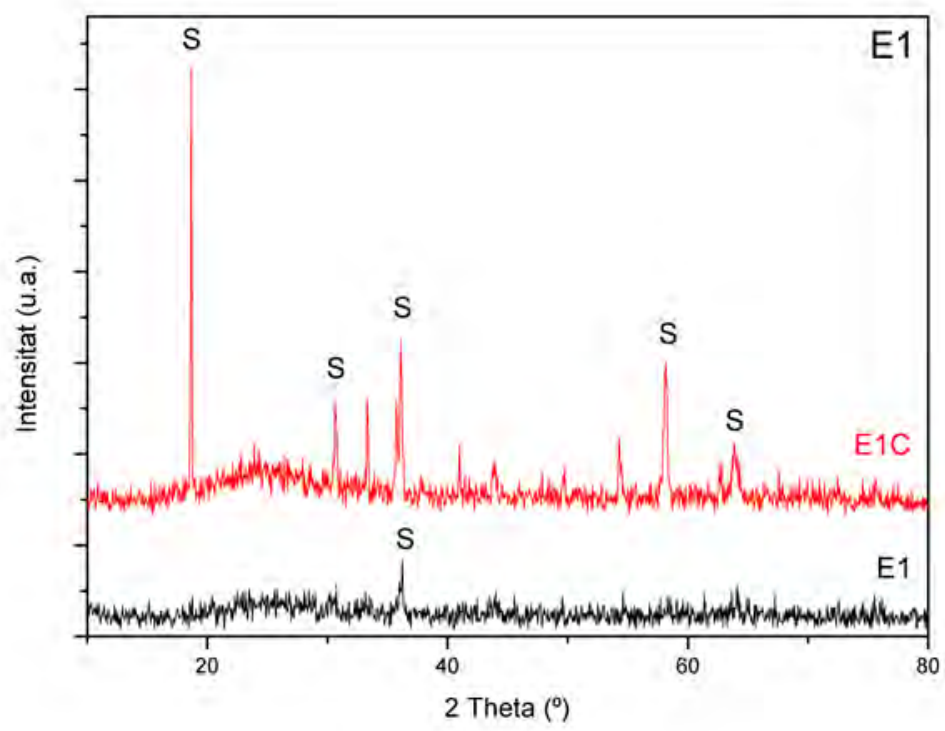

Figura 90 Difractograma de la superfície de les composicions E1 i E1C a cicle de cocció estàndard. 


\subsubsection{Composició I1.}

A continuació es presenten les anàlisis químiques de les composicions I1, fritada, i I1C, crua, a la Taula 45. Les variacions majors dels valors vénen donades per les pèrdues de pes com a resultat de les desgasificacions de la dolomita.

Taula 45 Anàlisis químiques de les composicions I1 i I1C.

\begin{tabular}{|l|c|c|c|c|c|c|c|c|c|c|c|}
\hline \% Pes & $\mathrm{Al}_{2} \mathrm{O}_{3}$ & $\mathbf{S i O}_{\mathbf{2}}$ & $\mathrm{Na}_{2} \mathrm{O}$ & $\mathbf{M g O}$ & $\mathrm{K}_{2} \mathrm{O}$ & $\mathbf{C a O}$ & $\mathrm{TiO}_{2}$ & $\mathbf{F e}_{2} \mathbf{O}_{3}$ & $\mathrm{Li}_{2} \mathrm{O}$ & $\mathbf{B}_{2} \mathbf{O}_{3}$ & PPC \\
\hline I1 & 7,9 & $\mathbf{5 4 , 2}$ & 8,2 & $\mathbf{8 , 1}$ & 0,5 & $\mathbf{1 5 , 6}$ & 0,2 & $\mathbf{4 , 8}$ & $<0,1$ & $<\mathbf{0 , 2 5}$ & 0,1 \\
\hline I1C & 5,2 & $\mathbf{4 5 , 9}$ & 7,3 & $\mathbf{6 , 9}$ & 0,4 & $\mathbf{1 4 , 7}$ & 0,2 & $\mathbf{4 , 7}$ & $<0,1$ & $<\mathbf{0 , 2 5}$ & 14,7 \\
\hline
\end{tabular}

A les micrografies estudiades, la peça esmaltada amb frita presentava gran quantitat de cristalls menuts a la secció. En canvi, si observem les micrografies de les peces esmaltades amb residus sense fritar trobem més partícules tant a la secció, a la Figura 91, com a la superfície, a la Figura 92:

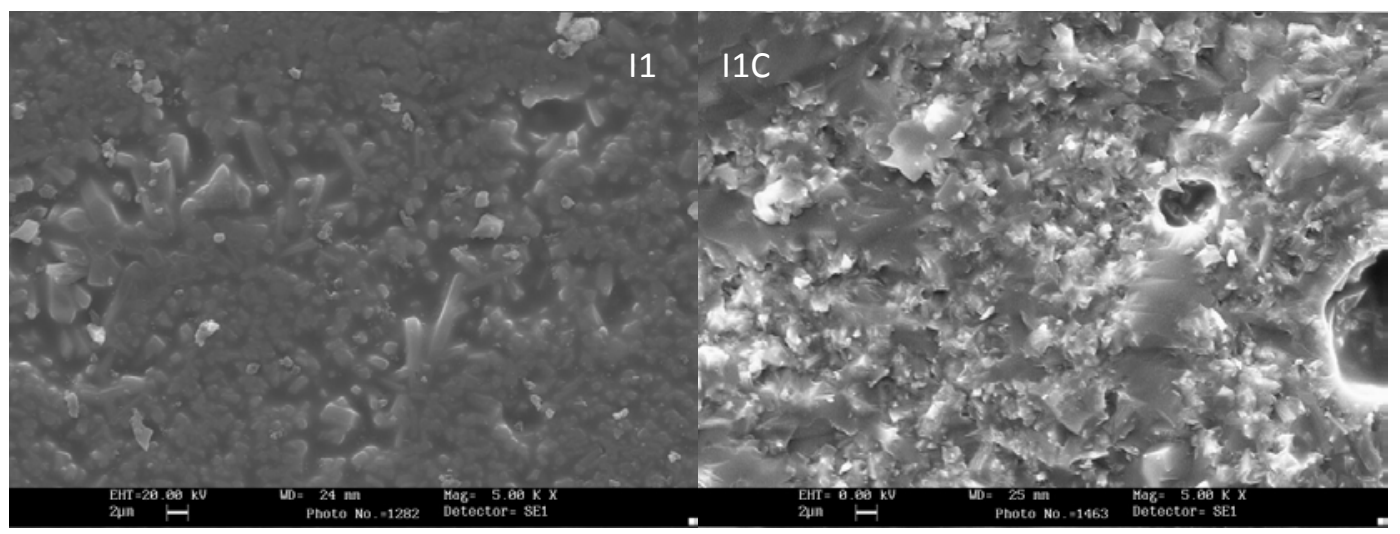

Figura 91 Micrografies de la secció de les composicions I1 i I1C.

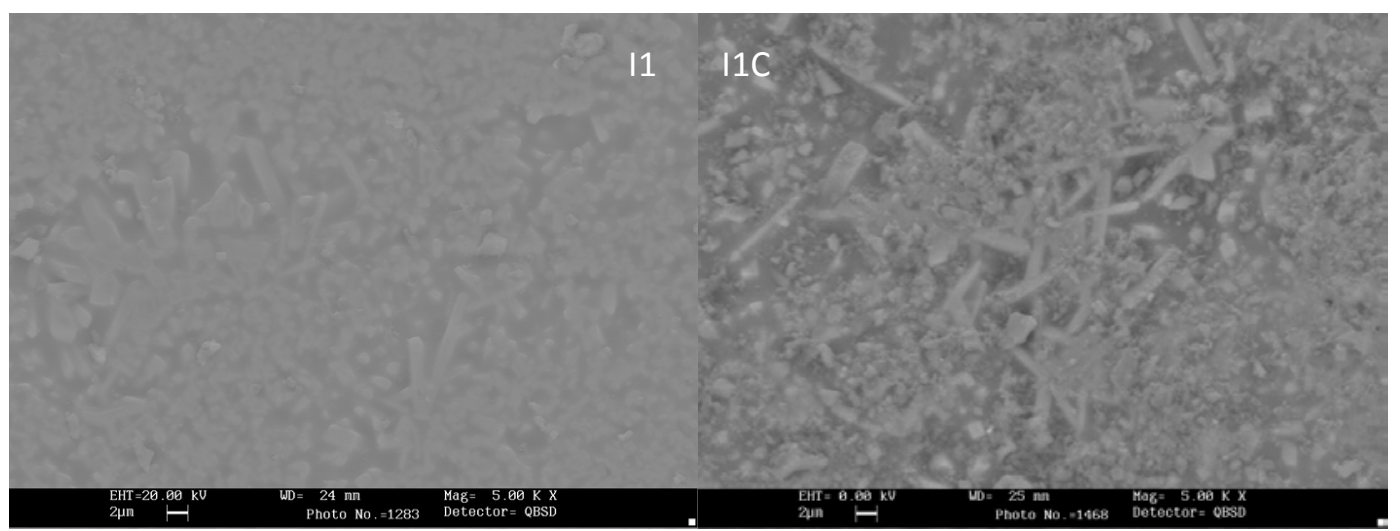

Figura 92 Micrografies de la superfície de les composicions I1 i I1C. 
Aquestes imatges concorden amb els resultats que s'observen de les anàlisis per DRX, que es poden observar a la Figura 93, on es troba augita en proporcions per damunt del 95\%:

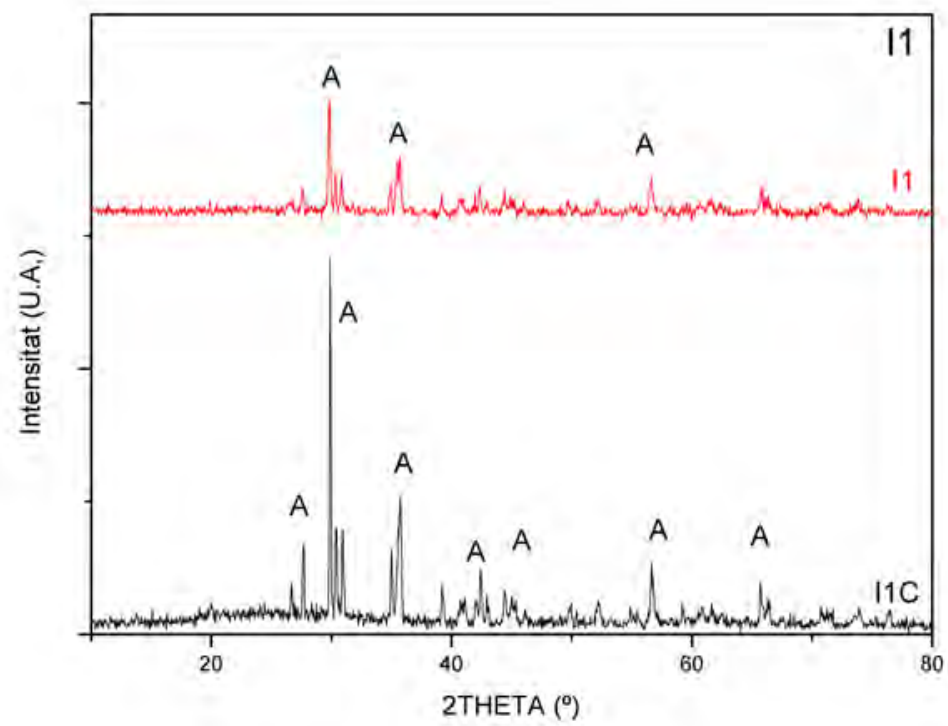

Figura 93 Difractograma de la superfície de les composicions I1 i I1C a cicle de cocció estàndard. 


\subsubsection{Composició I2.}

Es mostren en primer lloc les anàlisis químiques de les composicions I2, fritada, i I2C, crua, a la Taula 46. Les variacions majors dels valors vénen donades per les pèrdues de pes com a resultat de les desgasificacions de la dolomita.

Taula 46 Anàlisis químiques de les composicions I2 i I2C.

\begin{tabular}{|c|c|c|c|c|c|c|c|c|c|c|c|}
\hline \% Pes & $\mathrm{Al}_{2} \mathrm{O}_{3}$ & $\mathbf{S i O}_{2}$ & $\mathrm{Na}_{2} \mathrm{O}$ & $\mathbf{M g O}$ & $\mathrm{K}_{2} \mathrm{O}$ & $\mathbf{C a O}$ & $\mathrm{TiO}_{2}$ & $\mathbf{F e}_{2} \mathbf{O}_{3}$ & $\mathrm{Li}_{2} \mathrm{O}$ & $\mathbf{B}_{2} \mathbf{O}_{3}$ & $P P C$ \\
\hline $\mathbf{I 2}$ & 10,3 & $\mathbf{5 4 , 2}$ & 7,6 & $\mathbf{6 , 5}$ & 0,6 & $\mathbf{1 3 , 5}$ & 0,2 & $\mathbf{5 , 6}$ & $<0,1$ & $<\mathbf{0 , 2 5}$ & 0,1 \\
\hline $\mathbf{I 2 C}$ & 8,8 & $\mathbf{4 8 , 7}$ & 7,2 & $\mathbf{5 , 8}$ & 0,5 & $\mathbf{1 2 , 2}$ & 0,3 & $\mathbf{5 , 4}$ & $<0,1$ & $<\mathbf{0 , 2 5}$ & 9,5 \\
\hline
\end{tabular}

Quan comparem les imatges obtingudes per SEM, passa exactament igual que en la composició I1, amb més cristalls a la composició sense fritar, com s'aprecia a la Figura 94. A la superfície, en la Figura 95 es veu com, tot i que se pareixen més, la peça esmaltada amb frita presenta una superfície més regular que la preparada a partir de residus $i$ altres matèries primeres:

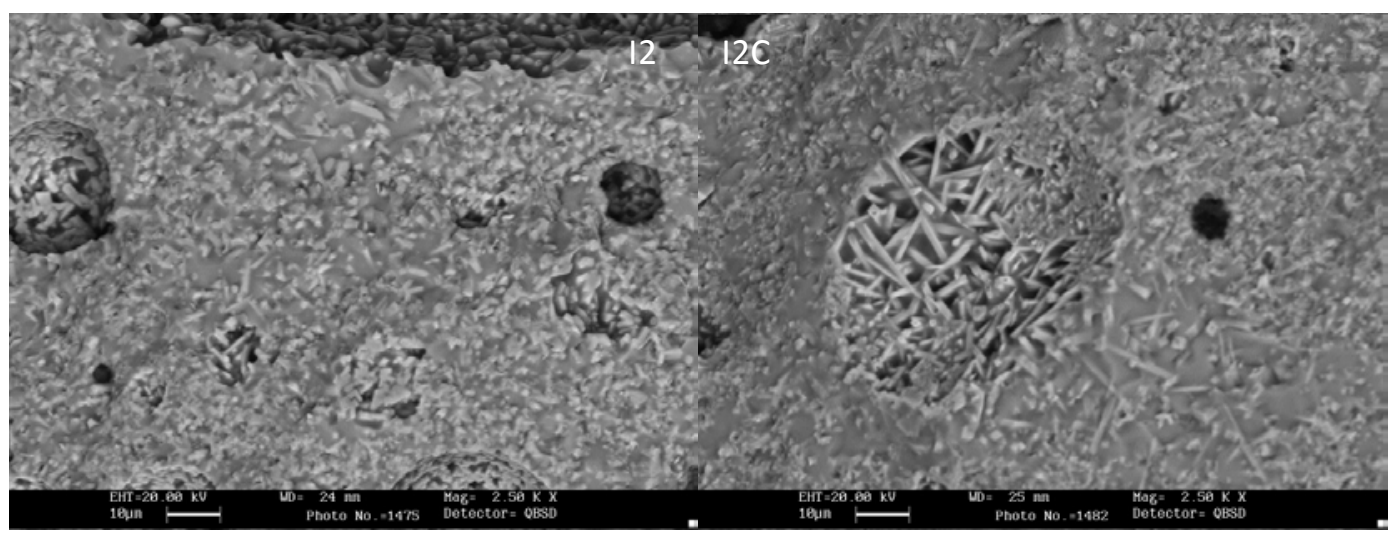

Figura 94 Micrografies de la secció de les composicions I2 i I2C.

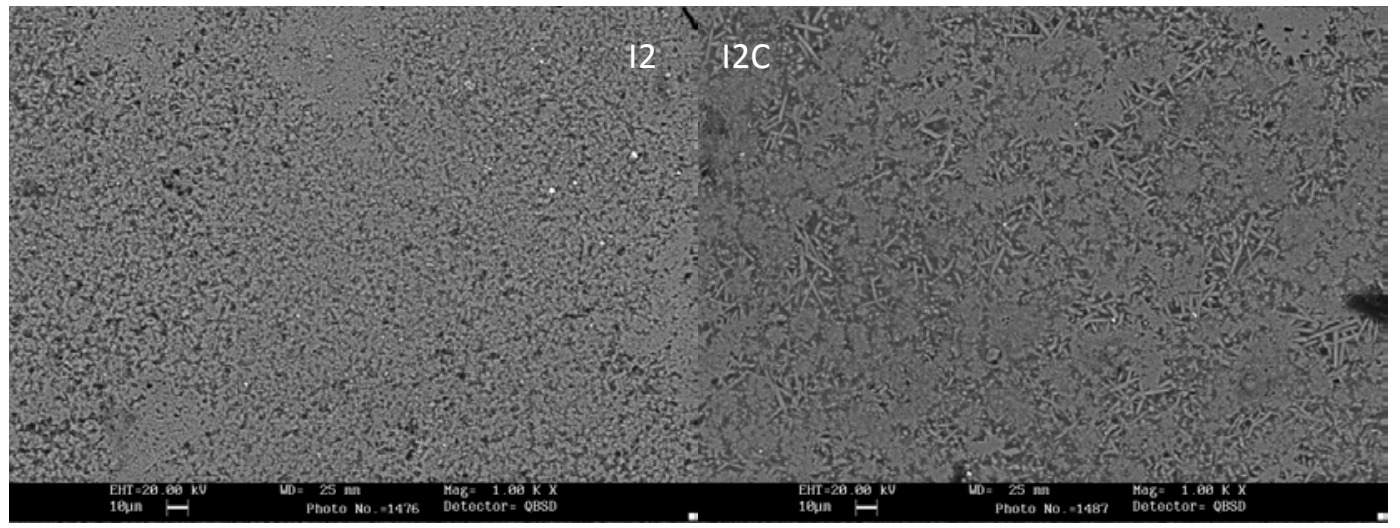

Figura 95 Micrografies de la superfície de les composicions 12 i I2C. 
Si s'analitzen els resultats de les anàlisis per DRX, a la Figura 96 es pot comprovar com es forma massivament cristalls d'augita a la superfície de les peces de composició I2, amb percentatges molt alts, per damunt del $\mathbf{9 0 \%}$ :

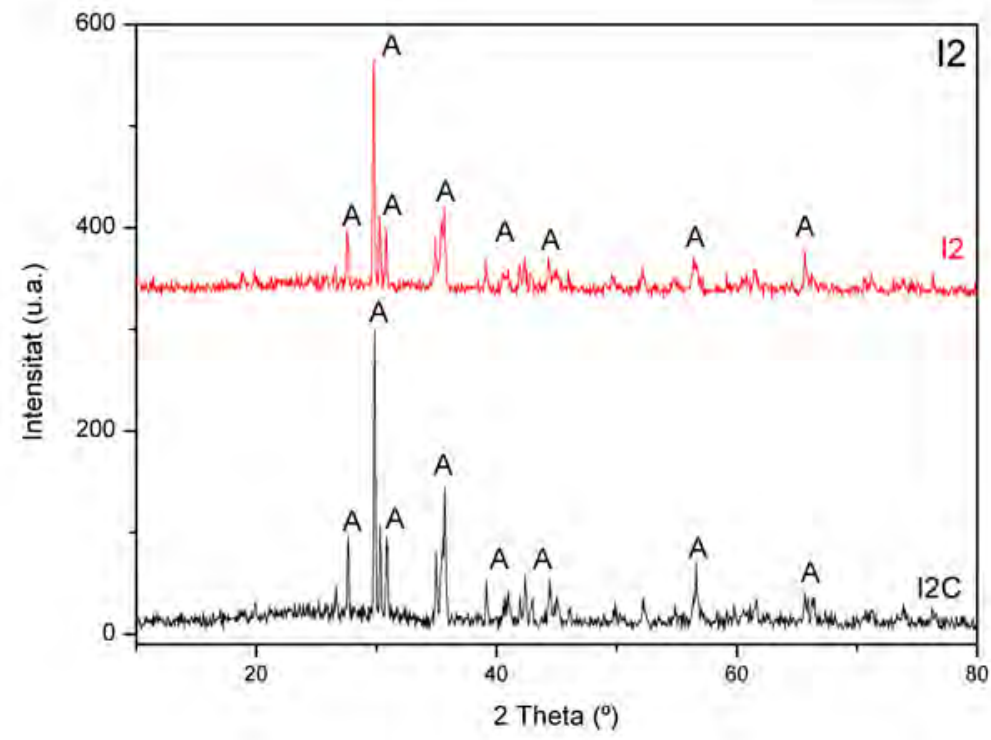

Figura 96 Difractograma de la superfície de les composicions 12 i I2C a cicle de cocció estàndard. 


\subsubsection{Composició J1.}

A continuació es presenten les anàlisis químiques de les composicions $\mathbf{J 1}$ i J1C, a Taula 47, aquesta vegada sense grans variacions de perduda de pes per calcinació degut a descomposicions.

Taula 47 Anàlisis químiques de les composicions J1 i J1C.

\begin{tabular}{|l|c|c|c|c|c|c|c|c|c|c|c|}
\hline \% Pes & $\mathrm{Al}_{2} \mathrm{O}_{3}$ & $\mathbf{S i O}_{2}$ & $\mathrm{Na}_{2} \mathrm{O}$ & $\mathbf{M g O}$ & $\mathrm{K}_{2} \mathrm{O}$ & $\mathbf{C a O}$ & $\mathrm{SrO}$ & $\mathbf{B a O}$ & $\mathrm{WO}_{3}$ & $\mathbf{P b O}$ & $\mathrm{PPC}$ \\
\hline $\mathbf{J 1}$ & 4,2 & $\mathbf{4 6 , 9}$ & 5,2 & $\mathbf{1 , 1}$ & 6,1 & $\mathbf{2 , 7}$ & 1,4 & $\mathbf{2 , 0}$ & 12,8 & $\mathbf{1 6 , 9}$ & $+0,2$ \\
\hline $\mathbf{J 1 C}$ & 2,9 & $\mathbf{4 8 , 0}$ & 5,8 & $\mathbf{1 , 1}$ & 7,2 & $\mathbf{2 , 8}$ & 1,3 & $\mathbf{2 , 2}$ & 9,0 & $\mathbf{1 6 , 1}$ & $+0,2$ \\
\hline
\end{tabular}

La peça esmaltada amb frita presenta gran quantitat de cristalls menuts a la secció. En canvi, si s'observen les micrografies de les peces esmaltades amb la composició sense fritar pareix que es troben menys partícules i cristalls, tant a la secció com a la superfície.

Cal destacar que les cristal·litzacions integrades a l'esmalt són partícules molt menudes, repartides a tot el volum, mentre que les grans estructures que s'observen tant a la secció, a la Figura 97, com a la superfície, a la Figura 98, són cristal·litzacions d'hidrotungstita produïdes per envelliment de les peces després de la secció.

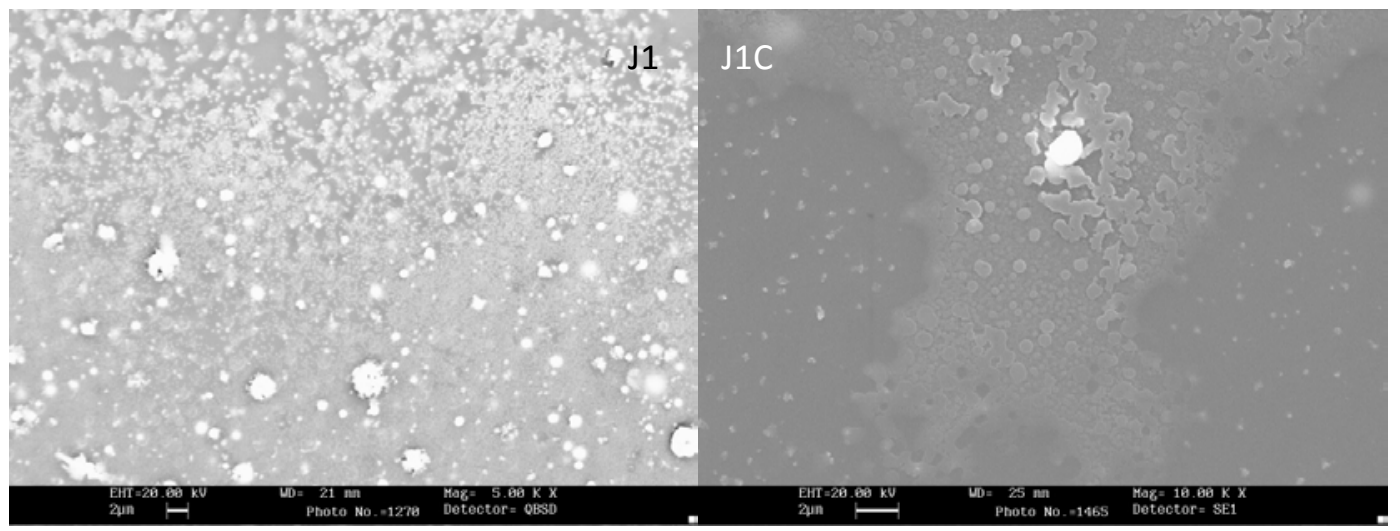

Figura 97 Micrografies de la secció de les composicions J1 i J1C.

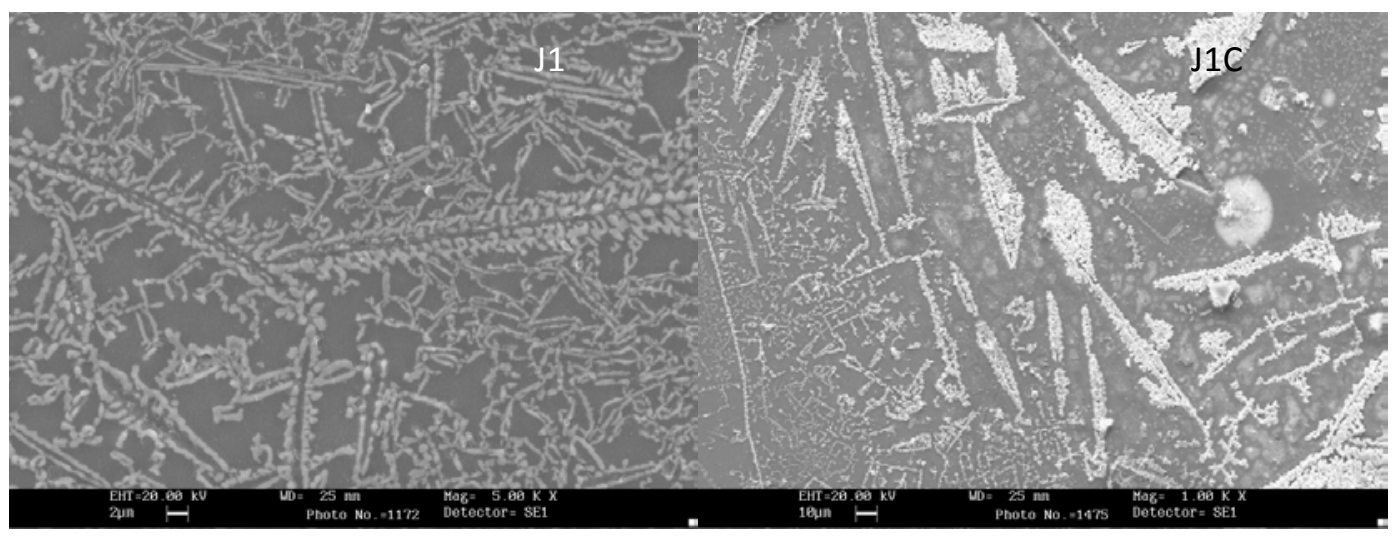

Figura 98 Micrografies de la superfície de les composicions J1 i J1C. 
A la Figura 99, on s'analitzen els resultats de les anàlisis DRX de les superfícies dels vidriats obtinguts a partir d'esmalts fritats i crus, es pot comprovar com la única fase que s'aprecia a la superfície és la hidrotungstita, no apareixent les altres fases acumulades a la superfície.

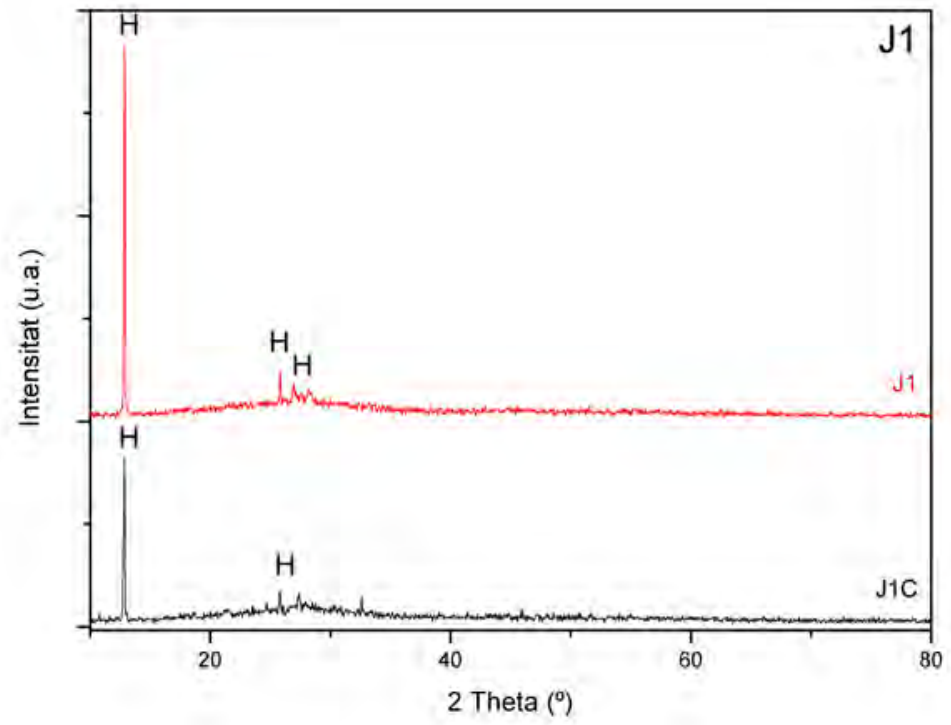

Figura 99 Difractograma de la superfície de les composicions J1 i J1C a cicle de cocció estàndard. 


\subsubsection{Composició J3.}

A continuació es presenten les anàlisis químiques de les composicions $\mathbf{J 3}$ i $\mathbf{J 3 C}$, a la Taula 48. No s'aprecien grans variacions al seus components.

Taula 48 Anàlisis químiques de les composicions J3 i J3C.

\begin{tabular}{|l|l|l|l|l|l|l|l|l|l|l|l|l|}
\hline \% Pes & $\mathrm{Al}_{2} \mathrm{O}_{3}$ & $\mathbf{S i O}_{\mathbf{2}}$ & $\mathrm{Na}_{2} \mathrm{O}$ & $\mathbf{M g O}$ & $\mathrm{K}_{2} \mathrm{O}$ & $\mathbf{C a O}$ & $\mathrm{SrO}$ & $\mathbf{B a O}$ & $\mathrm{CeO}_{2}$ & $\mathbf{W O}_{3}$ & $\mathrm{PbO}$ & $\mathbf{P P C}$ \\
\hline $\mathbf{J 3}$ & 4,2 & $\mathbf{4 5 , 6}$ & 5,2 & $\mathbf{1 , 1}$ & 6,4 & $\mathbf{2 , 7}$ & 1,2 & $\mathbf{1 , 9}$ & 8,6 & $\mathbf{4 , 1}$ & 14,6 & $\mathbf{0 , 0}$ \\
\hline $\mathbf{J 3 C}$ & 2,6 & $\mathbf{4 5 , 4}$ & 5,6 & $\mathbf{1 , 1}$ & 6,8 & $\mathbf{2 , 7}$ & 1,2 & $\mathbf{2 , 0}$ & 8,9 & $\mathbf{4 , 3}$ & 15,1 & $\mathbf{0 , 3}$ \\
\hline
\end{tabular}

La peça esmaltada amb frita presenta una quantitat apreciable de cristalls menuts a la secció. En canvi, si s'observen les micrografies de les peces esmaltades amb residus sense fritar es troben més partícules i cristalls, tant a la secció, a la Figura 100, com a la superfície, a la Figura 101, on es veuen clarament els diferents tipus de cristalls enllaçats, però amb diferents amplituds. Es pot observar aquesta xarxa de cristalls a la imatge ampliada en la Figura 102.

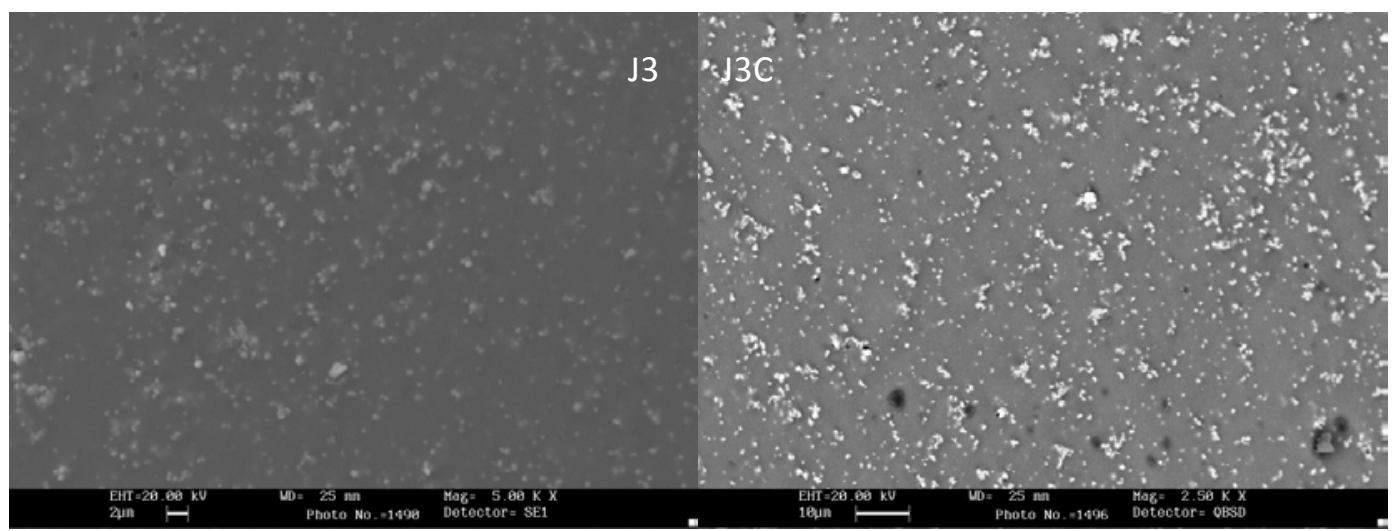

Figura 100 Micrografies de la secció de les composicions J3 i J3C.

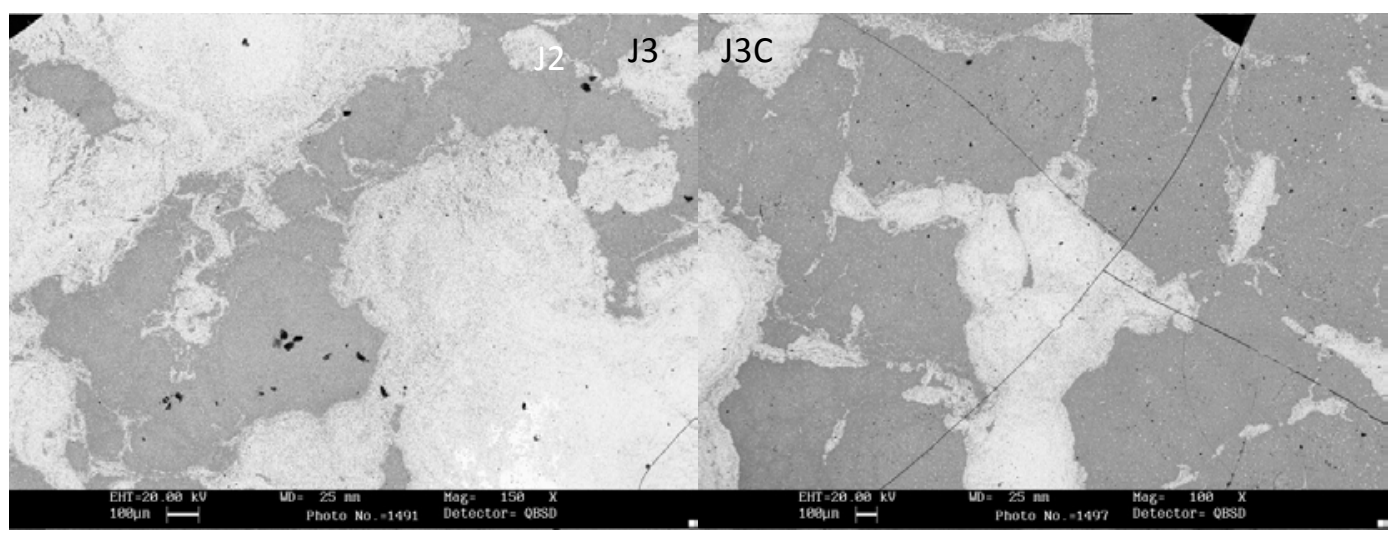

Figura 101 Micrografies de la superfície de les composicions J3 i J3C. 


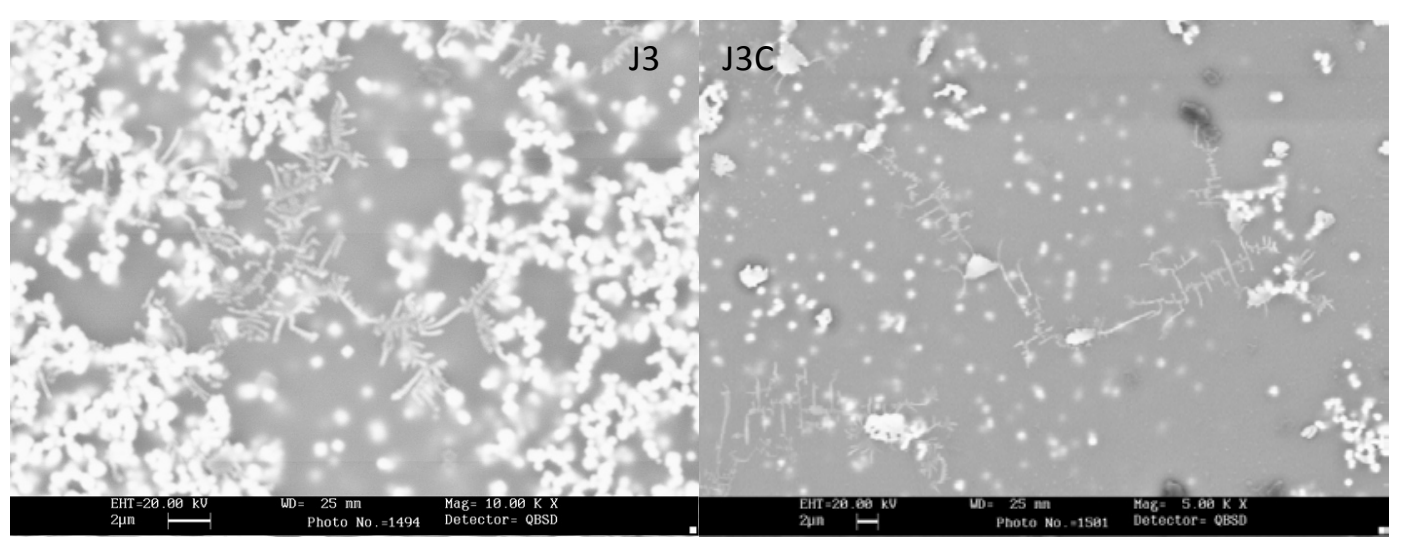

Figura 102 Micrografies de la superfície ampliada de les composicions J3 i J3C.

Si s'estudia les fases formades a la superfície de la composició J3, a la Figura 103, es pot comprovar com la fase principal en tots els casos és la cerianita:

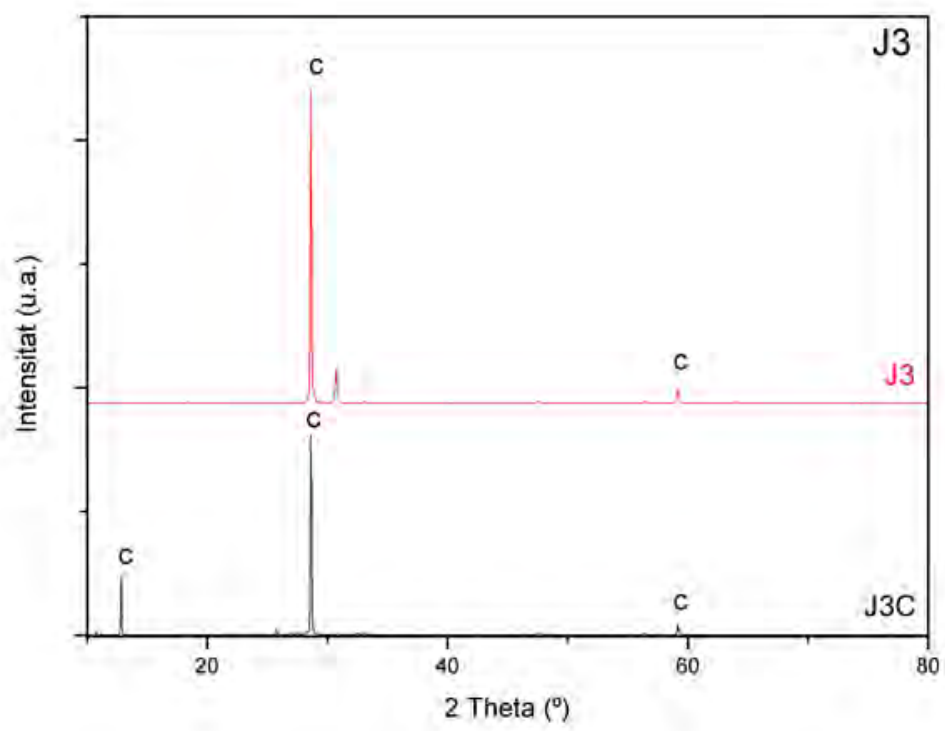

Figura 103 Difractograma de la superfície de les composicions J3 i J3C a cicle de cocció estàndard. 


\subsection{Estudi de la cocció final de les composicions seleccionades en forn monostrat elèctric amb làser incorporat.}

En total s'han passat 9 mostres, és a dir, les 7 composicions seleccionades a més de una peça acolorida i una altra amb aplicació serigràfica. Es tornen a caracteritzar totes les mostres comparativament, ja que la cinètica d'escalfat en forns a escala de laboratori (mufles) pot variar fortament de les condicions dels forns monostrat [115].

Cal mostrar en primer lloc les DRX comparatives entre les peces esmaltades amb les composicions fritades, les crues sense aplicació de radiació làser, referenciades amb el sufix (C), i les crues amb la radiació aplicada a la zona de precocció, referenciades amb el sufix $(\mathbf{C L})$.

A continuació es mostren les micrografies de la superfície, la secció i les microanàlisis EDX de la superfície dels vidriats, per tal d'estudiar la seva morfologia i els possibles canvis de composicions degut a les evaporacions en els diferents processos de fabricació i l'aplicació del làser.

En primer lloc, cal destacar que, en general, els esmalts han sofert una variació en el seu aspecte superficial en coure en un forn monostrat, en lloc del forn mufla de laboratori com s'havien cuit fins ara.

\subsubsection{Composició A1.}

Es pot comprovar que la composició A1 presenta un bon estirat en aquesta cocció, sense defectes aparents, i una coloració roja característica, provocada per el seu alt contingut en ferro, com es pot veure a la Figura 104.

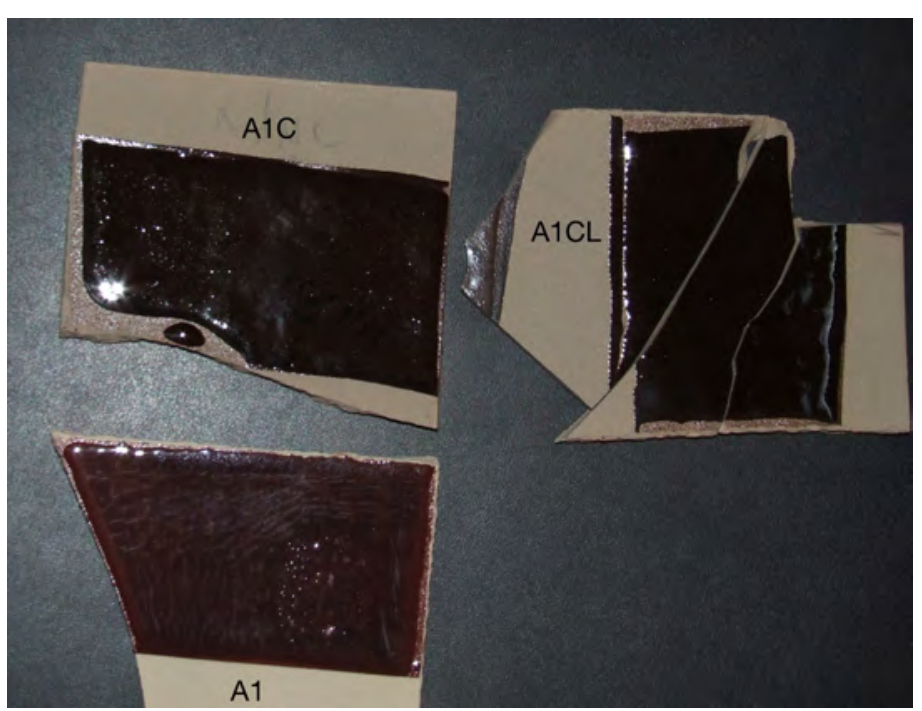

Figura 104 Peces de les composicions A1, A1C i A1CL cuites al forn monostrat. 
A continuació es presenten les anàlisis per DRX de les peces passades per el forn monostrat amb làser incorporat, on $\mathbf{A 1}$ és la composició fritada, A1C la composició crua sense aplicació de làser, i $\mathbf{A 1 C L}$, la composició crua tractada amb làser, a la Figura 105.

En aquest cas s'observa com a l'aplicar radiació a la zona de cocció augmenta la cristal·lització respecte de l'obtinguda a la peça crua, sense fritar. Si es quantifiquen de forma aproximada les fases, s'obté un $\mathbf{9 4 \%}$ de hematites en la peça fritada, un $\mathbf{5 7 \%}$ en la peça crua i un $\mathbf{7 0 \%}$ quan s'aplica radiació làser sobre l'esmalt sense fritar.

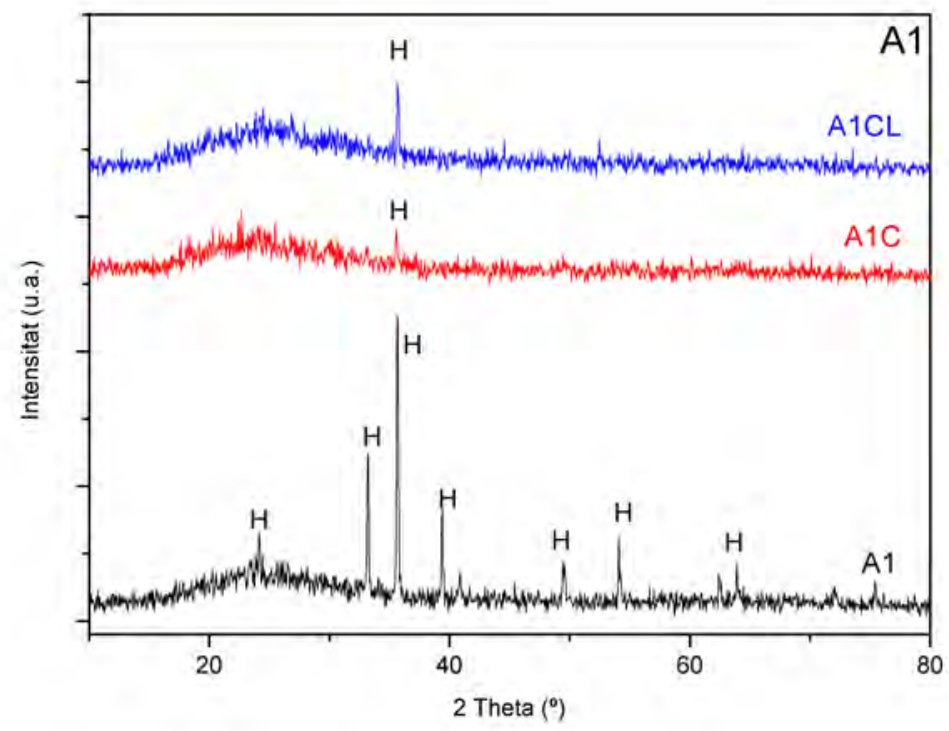

Figura 105 Difractograma de la composició A1 al forn monostrat.

En referència a les micrografies obtingudes per SEM de les mateixes peces, a la Figura 106 , es veu en primer lloc la peça fritada amb cristalls a la secció recent (A1) i a la superfície (A1s) similars a les obtingudes en el forn mufla, amb cristal-litzacions regulars a l'interior i zones amb cristal-litzacions molt irregulars a la superfície:

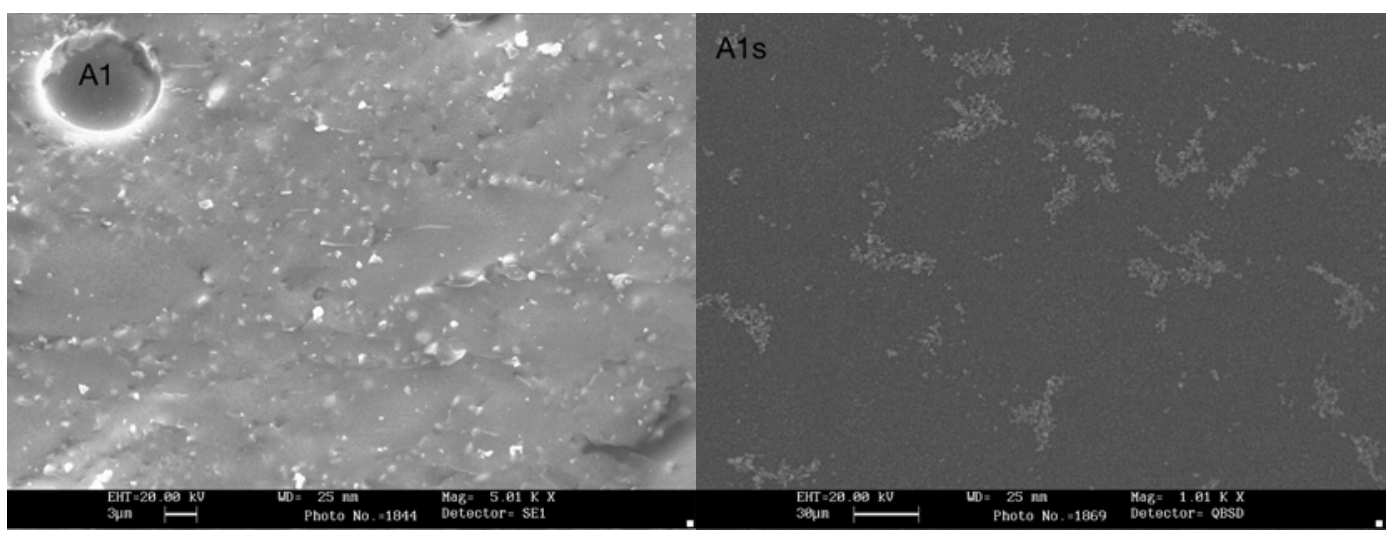

Figura 106 Micrografies de la composició A1 fritada, cuita en forn monostrat, a la secció (A1) i a la superfície (A1s). 
Quan s'estudia la Figura 107, del esmalt cru, fet amb residus, es veu tant a la secció com a la superfície una estructura molt similar. Sols cal destacar que quan s'amplia la imatge de la superfície s'observa que els cristalls que hi ha són més irregulars en forma i mida que quan es parteix del mateix esmalt fritat.

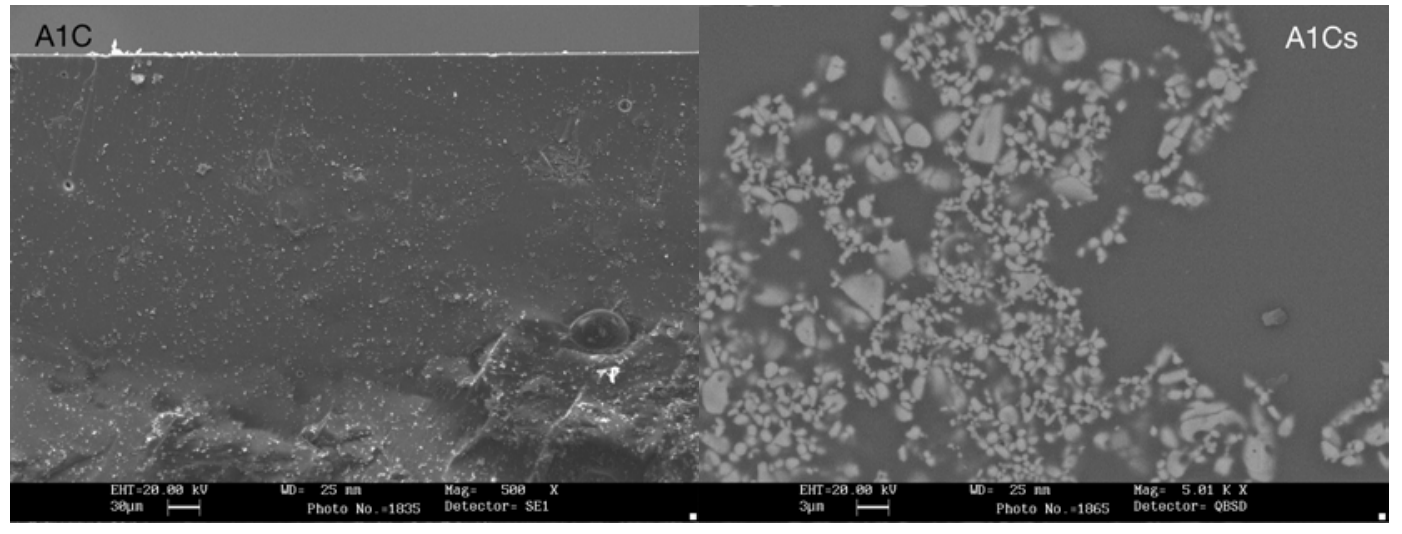

Figura 107 Micrografíes de la composició A1 crua a la secció (A1C) i a la superfície (A1Cs), cuites en un forn monostrat.

Finament, a la Figura 108, es pot comparar amb les micrografies fetes sobre peces tractades amb radiació làser. S'observa com la capa superficial està totalment fosa, fins on ha arribat la radiació, i les estructures cristal·lines superficials són menys nombroses que en absència de radiació.

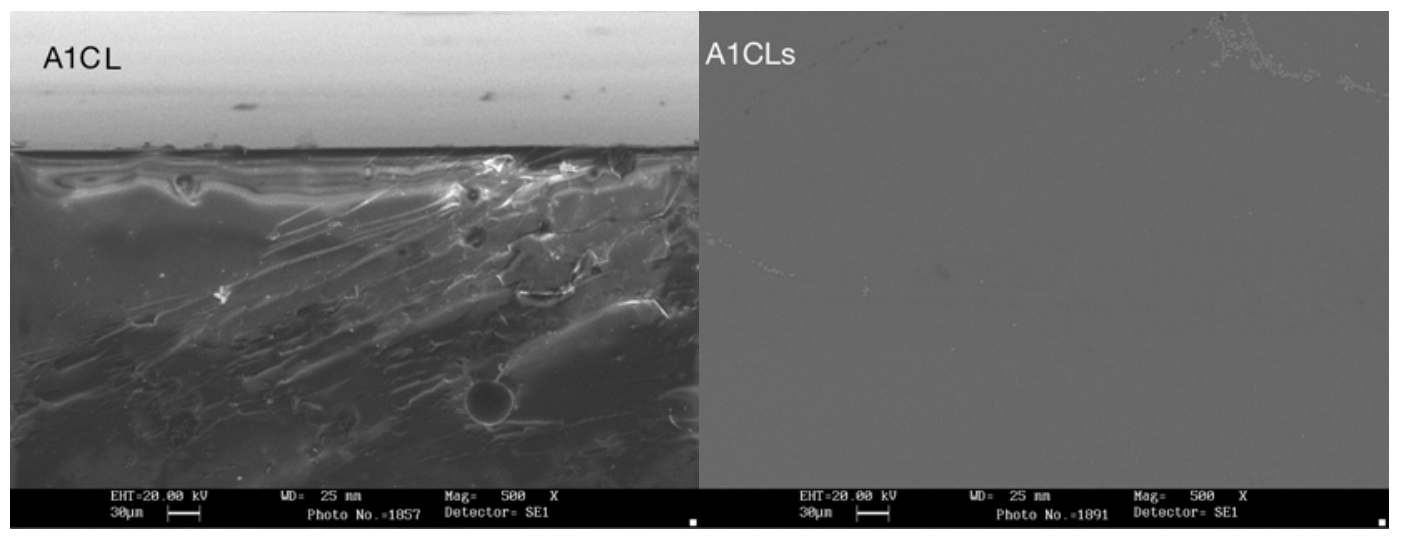

Figura 108 Micrografies de la secció (A1CL) i la superfície (A1CLs) de la composició A1 crua amb aplicació de radiació làser.

Per explicar aquests resultats cal fixar-se en els resultats obtinguts als diagrames TTT de les superfícies. En aquest estudi es veu com les fases trobades a la superfície d'aquesta composició depenen en part del cicle de cocció, tot i que no totalment. Això vol dir que en aplicar la radiació fonem totalment els cristalls d'hematites formats durant l'escalfament, que no tenen temps de tornar a formar-se durant el refredament a cicle estàndard.

És important destacar que com esta capa formada és transparent, sí que s'observa un lleuger augment de la quantitat d'hematites mesurada en DRX de la superfície de la 
peça irradiada respecte de la idèntica sense irradiar. Açò vol dir que, tot i que no s'augmenta la quantitat de cristalls formats directament a la superfície, si que pareix que aquesta radiació potència el desenvolupament de més cristalls formats directament baix de la capa fosa, obtenint una proporció de fase formada intermitjana entre la composició A1 crua i la fritada.

S'ha realitzat unes anàlisis EDX a la superfície de les peces, per poder comparar les fases evaporades en cada cas, mostrades a la Taula 49:

Taula 49 Microanàlisis per dispersió d'energies de raigs $\mathrm{X}$ de la superfície de les peces A1, A1C i A1CL.

\begin{tabular}{|cc|c|c|}
\hline Fórmula & $\mathbf{A 1}$ & $\mathbf{A 1 C}$ & $\mathbf{A 1 C L}$ \\
\hline $\mathrm{SiO}_{\mathbf{2}}$ & $\mathbf{6 0 , 6 9}$ & $\mathbf{5 6 , 7 4}$ & $\mathbf{6 0 , 4 8}$ \\
$\mathrm{Al}_{2} \mathrm{O}_{3}$ & 12,41 & 9,10 & 10,41 \\
$\mathbf{C a O}$ & $\mathbf{9 , 3 7}$ & $\mathbf{7 , 4 5}$ & $\mathbf{6 , 8 0}$ \\
$\mathrm{FeO}$ & 17,53 & 20,03 & 14,16 \\
$\mathrm{Na} 2$ & $\mathbf{0}$ & $\mathbf{6 , 6 9}$ & $\mathbf{4 , 7 2}$ \\
$\mathrm{MgO}$ & 0 & 0 & 3,42 \\
\hline
\end{tabular}

En principi, la superfície amb l'aplicació làser és la més similar a la composició de la pols inicial, ja que l'hematites cristal-lina segregada durant l'escalfament s'han fos amb l'aplicació de la radiació, quedant la fase vítria amb una composició més similar a la frita fosa. 


\subsubsection{Composició B1}

En primer lloc, es mostra una imatge de les peces esmaltades, on es pot comprovar que aquesta composició cuita al forn monostrat presenta un aspecte transparent, cosa que indica normalment una falta de cristal-linitat. Tot i això, es pot comprovar a la Figura

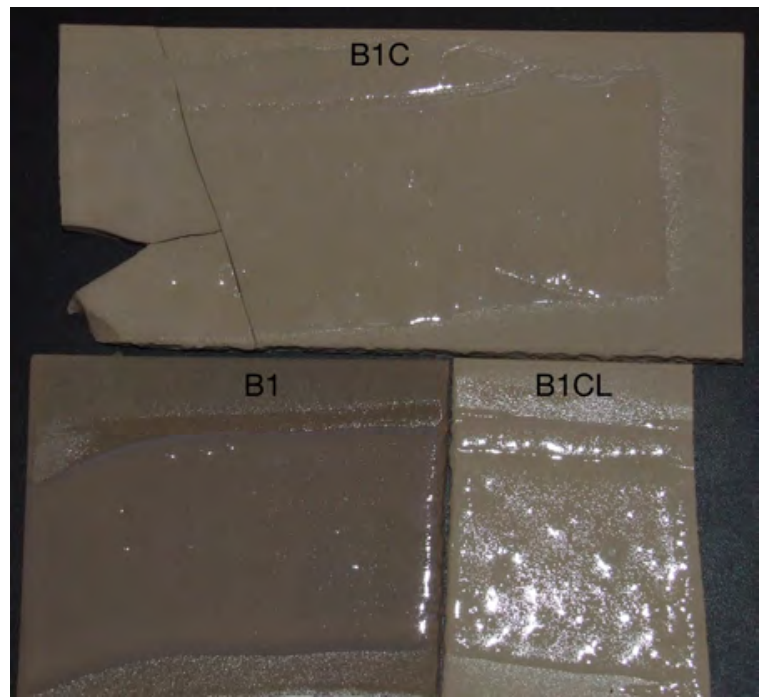
109 com els vidriats presenten un bon estirat, però amb molts punxats que podrien indicar que el cicle de cocció a que han estat sotmeses ha aportat més calor a les peces del que és adient.

A continuació es presenten les anàlisis de microscòpia de rastreig electrònic de les peces passades per el forn monostrat amb làser incorporat, on $\mathbf{B 1}$ és la composició fritada, B1C la composició crua sense aplicació de làser, i B1CL, la composició crua tractada amb làser, a la Figura 110.

Figura 109 Peces de les composicions B1, B1C i B1CL cuites al forn monostrat.

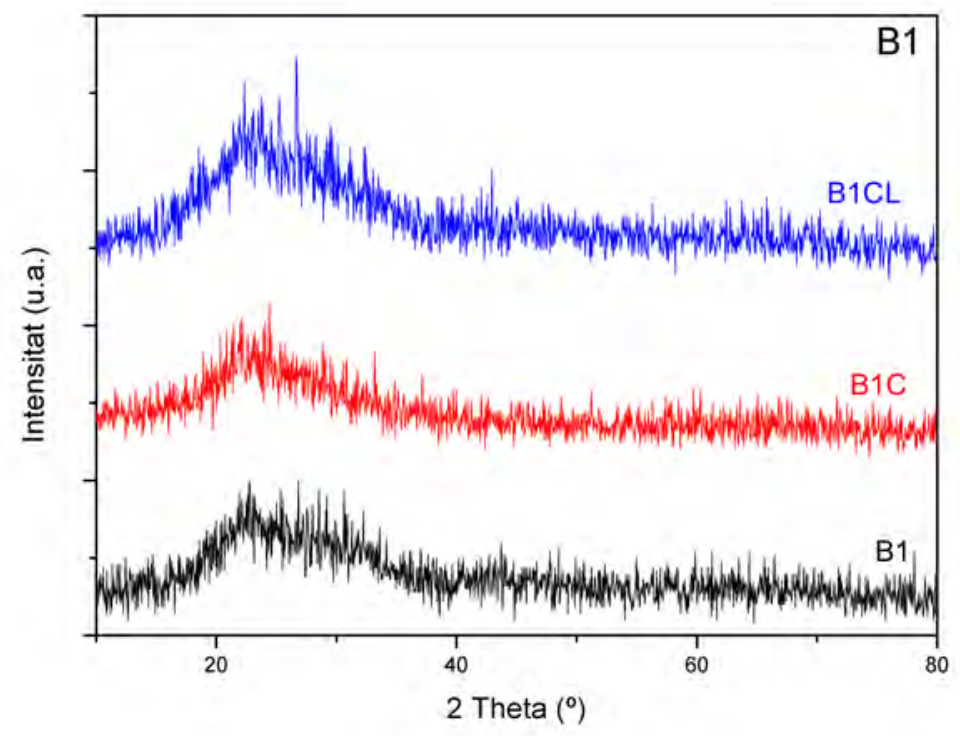

Figura 110 Difractograma de la composició B1 al forn monostrat.

En aquest cas no es veu clarament la diferencia entre les estructures formades a les tres superfícies, ja que són clarament amorfes. Es pot comprovar en les micrografies obtingudes de la secció i la superfície de la peça a la que s'ha aplicat la radiació, a la Figura 111, on s'observa que no hi ha variacions de composicions, ni s'observa cap tipus de cristal·lització ni a la superfície (B1CLs) ni a la secció (B1CL). 
RECERCA DE NOUS VIDRIATS, FORMULATS A PARTIR DE RESIDUS, I OBTINGUTS PER MITJÀ DE NOVES TECNOLOGIES DE PROCESSAT CERÀMIC

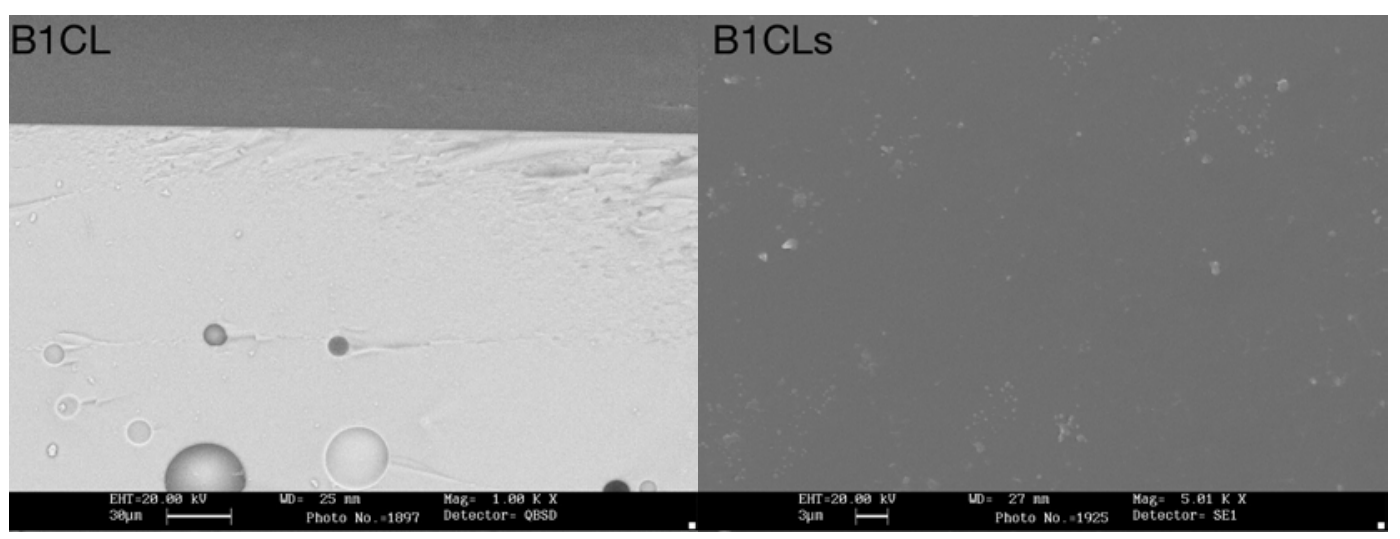

Figura 111 Micrografies de la secció (B1CL) i la superfície (B1CLs) de la composició B1 cruga amb aplicació de radiació láser. 


\subsubsection{Composició E1.}

Com s'observa a la Figura 112 aquesta composició presenta un aspecte punxat i rebullit, tant les que han segut tractades amb làser com les que no. Per tant, tot i que continuem l'estudi tècnic amb elles, cal destacar que caldria emprar-lo a un cicle de cocció a temperatura inferior, amb un tractament tèrmic diferent.

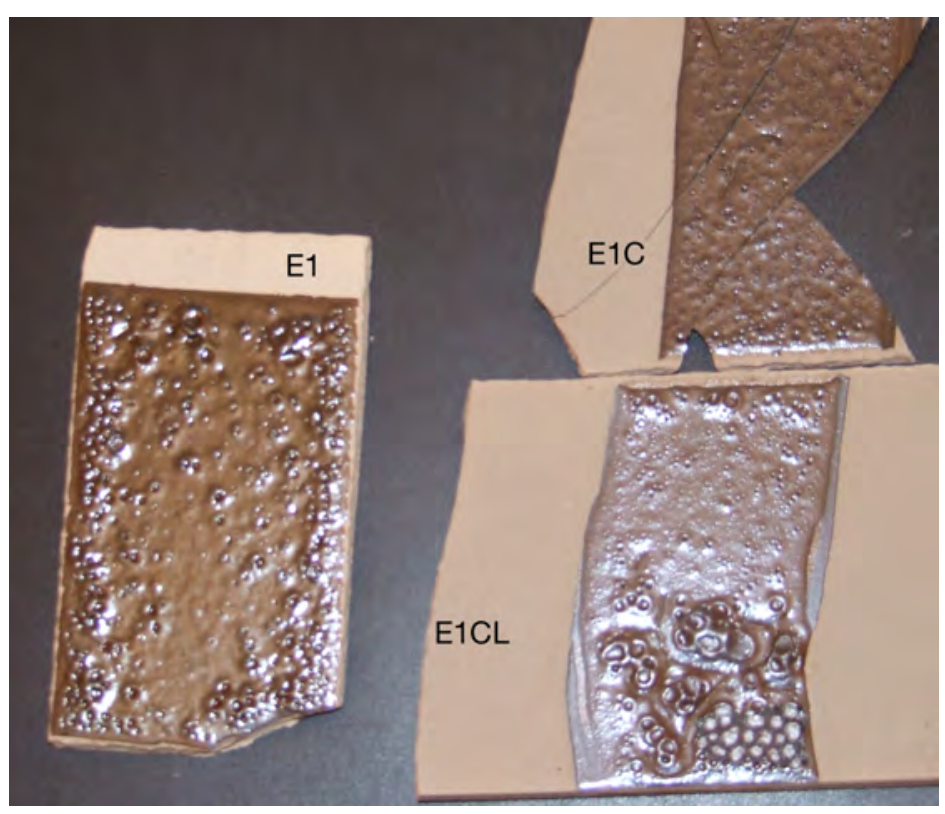

A continuació es presenten els resultats de les anàlisis de DRX de les peces cuites al forn monostrat $a m b$ làser incorporat, on E1 és la composició fritada, E1C la composició crua sense aplicació de làser, i E1CL, la composició crua tractada amb làser, a la Figura 113.

Figura 112 Peces de les composicions E1, E1C i E1CL cuites al forn monostrat.

En aquest cas s'aprecia un lleuger augment d'una de les fases, el silicat de ferro, quan s'aplica la radiació làser respecte de les fases formades en la peça crua. Cal recordar que la relació entre el temps de refredament i el desenvolupament de les fases formades en aquesta formulació no era concloent.

De tota manera es calcula que els percentatges de fase cristal-lina de silicat de ferro en la superfície de les peces estan en els tres casos per damunt del $\mathbf{9 0 \%}$. 


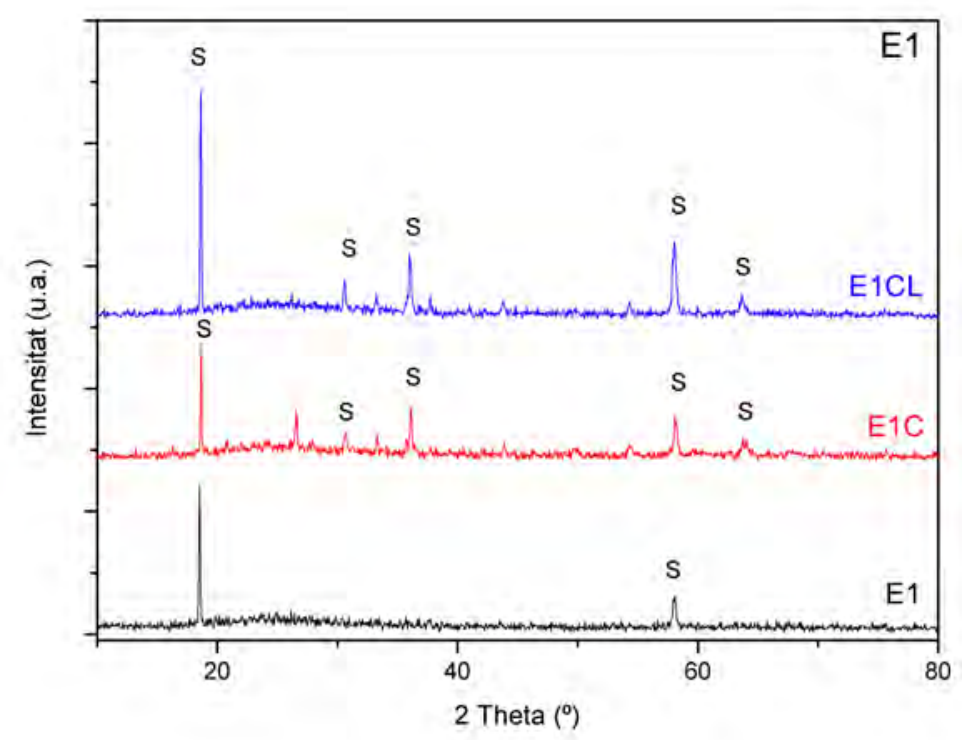

Figura 113 Difractograma de la composició E1 al forn monostrat.

Si s'observen les imatges obtingudes per SEM de la peça tractada amb radiació làser, a la Figura 114, es veu com s'acumulen els cristalls de silicat de ferro a la superfície tractada amb làser, i com hi ha una menor concentració també a la secció del vidriat.

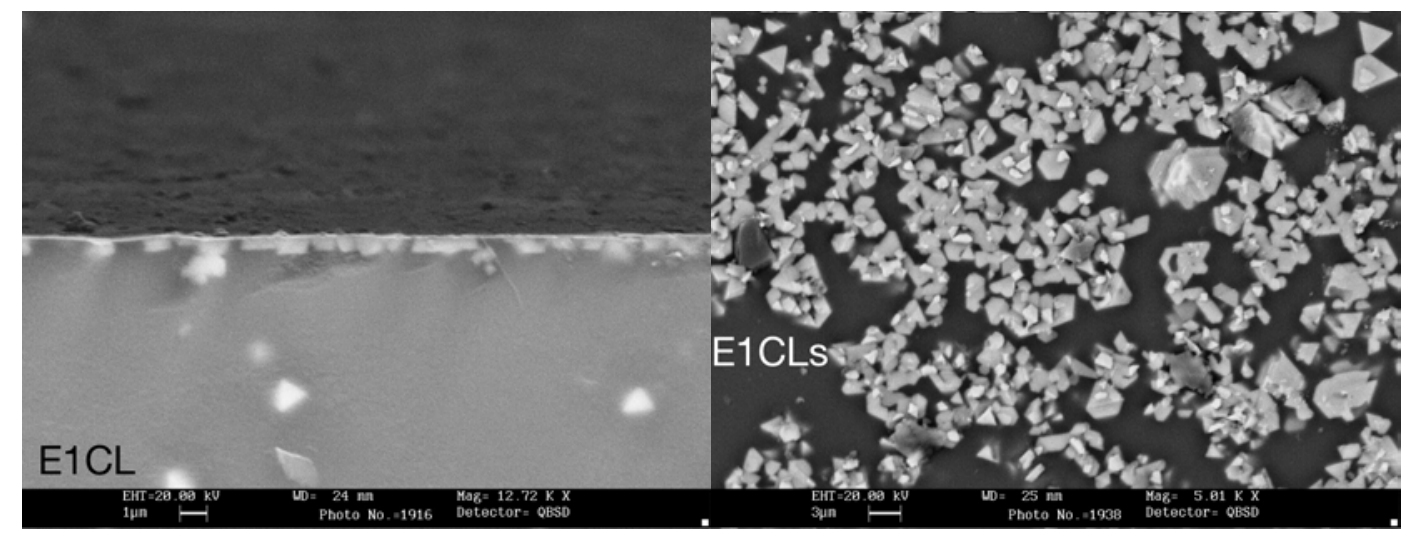

Figura 114 Micrografies de la secció (E1CL) i la superfície (E1CLs) de la composició E1 cruga amb aplicació de radiació làser.

En aquest cas, l'aspecte de les peces amb aplicació làser tenen un aspecte molt similar al que presenten les peces a les que no se'ls ha aplicat, en aquest cicle de cocció. S'haurien de fer proves amb cicles de cocció menys energètics. 
S'ha realitzat unes anàlisis EDX a la superfície de les peces, per poder comparar les fases evaporades en cada cas, i es mostren a la Taula 50, on destaca un augment del contingut de ferro en la superfície, que es podria interpretar com un augment de cristalls de silicat de ferro.

Taula 50 Microanàlisis per dispersió d'energies de raigs $X$ de la superfície de les peces E1, E1C i E1CL.

\begin{tabular}{|cc|c|c|}
\hline Fórmula & $\mathbf{E 1}$ & $\mathbf{E 1 C}$ & $\mathbf{E 1 C L}$ \\
\hline $\mathrm{SiO}_{\mathbf{2}}$ & $\mathbf{3 3 , 5 8}$ & $\mathbf{3 2 , 8 8}$ & $\mathbf{3 1 , 2 6}$ \\
$\mathrm{Al}_{2} \mathrm{O}_{3}$ & 24,65 & 25,65 & 18,86 \\
$\mathbf{C a O}$ & $\mathbf{1 , 6 7}$ & $\mathbf{1 , 6 6}$ & $\mathbf{1 , 7 9}$ \\
$\mathrm{FeO}$ & 28,61 & 28,41 & 37,09 \\
$\mathrm{Na}_{2} \mathbf{O}$ & $\mathbf{2 , 1 8}$ & $\mathbf{2 , 4 3}$ & $\mathbf{3 , 2 9}$ \\
$\mathrm{MgO}$ & 6,37 & 8,97 & 5,33 \\
$\mathrm{~K}_{\mathbf{2}} \mathbf{O}$ & $\mathbf{2 , 9 3}$ & - & $\mathbf{1 , 1 6}$ \\
\hline
\end{tabular}




\subsubsection{Composició I1.}

Es comença per mostrar imatges de les peces cuites, on I1 és la composició fritada, I1C la composició crua sense aplicació de làser, i I1CL, la composició crua tractada amb làser. Es pot comprovar com aquesta composició presenta una coloració veig, degut al contingut en ferro. També es pot observar que, tot i que les peces I1 i I1C presenten una textura rugosa, la peça irradiada, I1CL, presenta una capa de vidre recobrint aquesta superfície rugosa, a la Figura 115 .

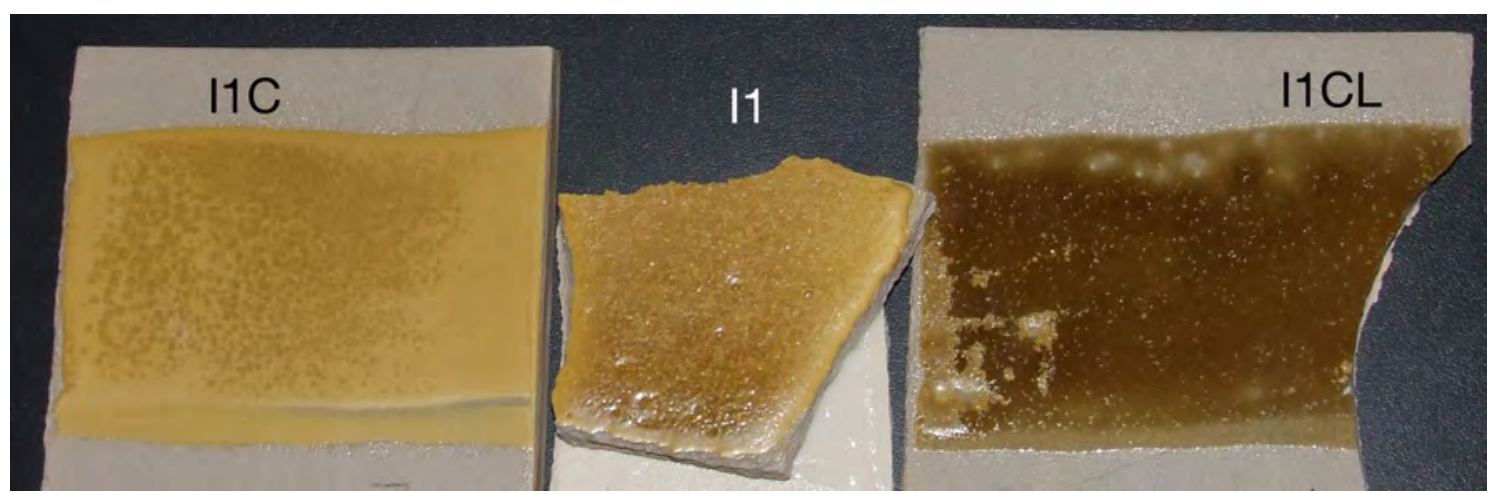

Figura 115 Peces de les composicions I1, I1C i I1CL cuites al forn monostrat.

A continuació es mostren els resultats de les anàlisis de DRX de les peces passades per el forn monostrat amb làser incorporat, , a la Figura 116:

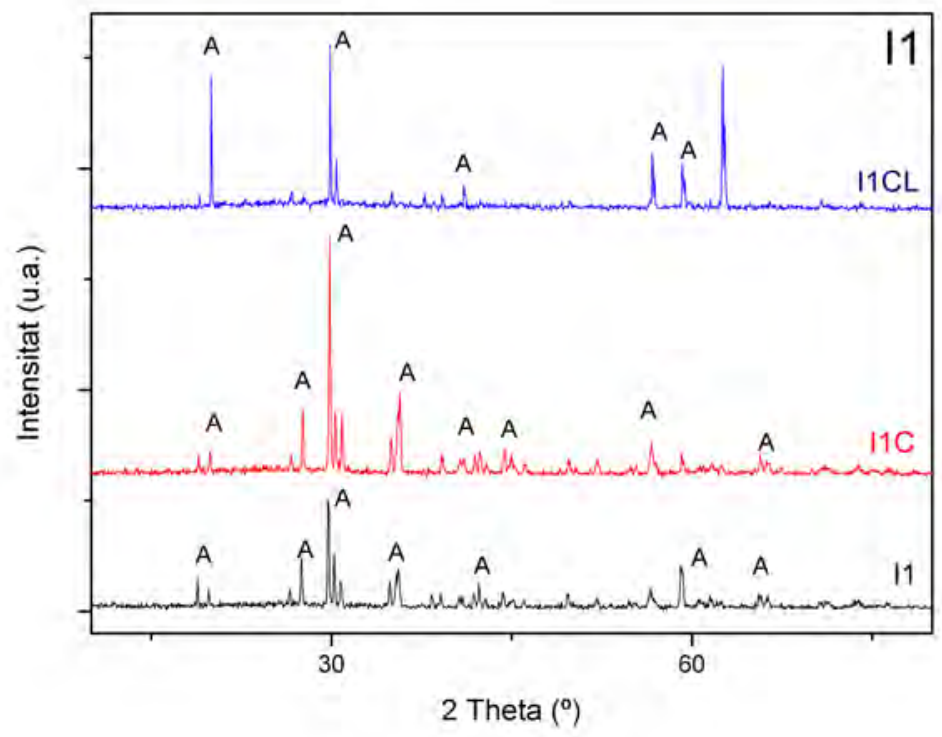

Figura 116 Difractometria de la composició I1 al forn monostrat. 
En aquest cas canvia l'orientació de les fases formades, tot i que els picus són de la mateixa fase, $\mathrm{i}$ les peces presenten un aspecte més brillant, ja que s'ha fos el material a l'arribar a la temperatura màxima. Recordem que aquesta composició, com la I2, no hi havia pràcticament variacions en la cristal-lització formada a diferents temps de manteniment en el refredament. Açò vol dir que es formen les cristal-litzacions durant l'escalfament $\mathrm{i}$ no es dissolen a l'arribar a la temperatura màxima, en absència de radiació. En aquest cas s'obté un material també amb la fase cristal-lina molt desenvolupada, però amb una superfície molt més fina i brillant.

A continuació, si s'observen els difractogrames obtinguts per SEM de les mateixes peces, a la Figura 117, es veu en primer lloc la peça fritada amb cristalls a la secció recent (I1) i a la superfície (I1s) similars a les obtingudes en el forn mufla, amb grans cristal·litzacions tant a l'interior com a la superfície:

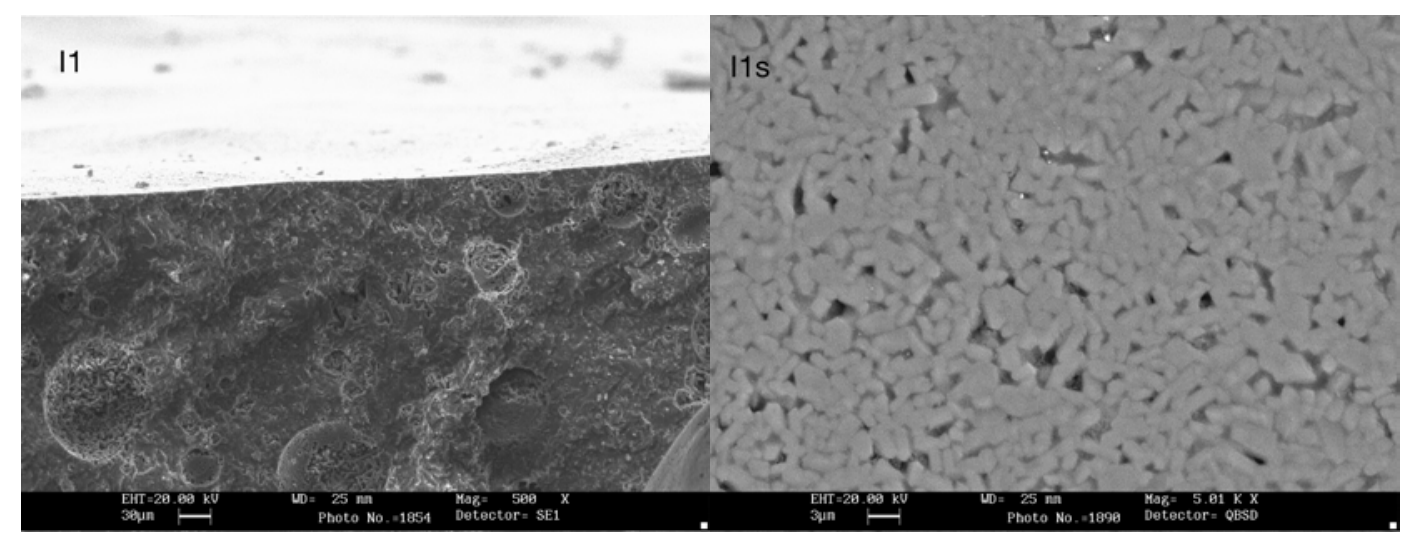

Figura 117 Micrografíes de la composició l1 fritada al forn monostrat, a la secció (I1) i la superfície (I1s).

A continuació s'observen les modificacions que hi ha quan es prepara la mostra amb els materials sense fritar, a la Figura 118. No s'aprecien grans canvis de estructura respecte a la peça anterior. En tot cas, es pot comprovar que els cristalls formats a la superfície tenen una mida més heterogènia, formen una superfície més irregular.

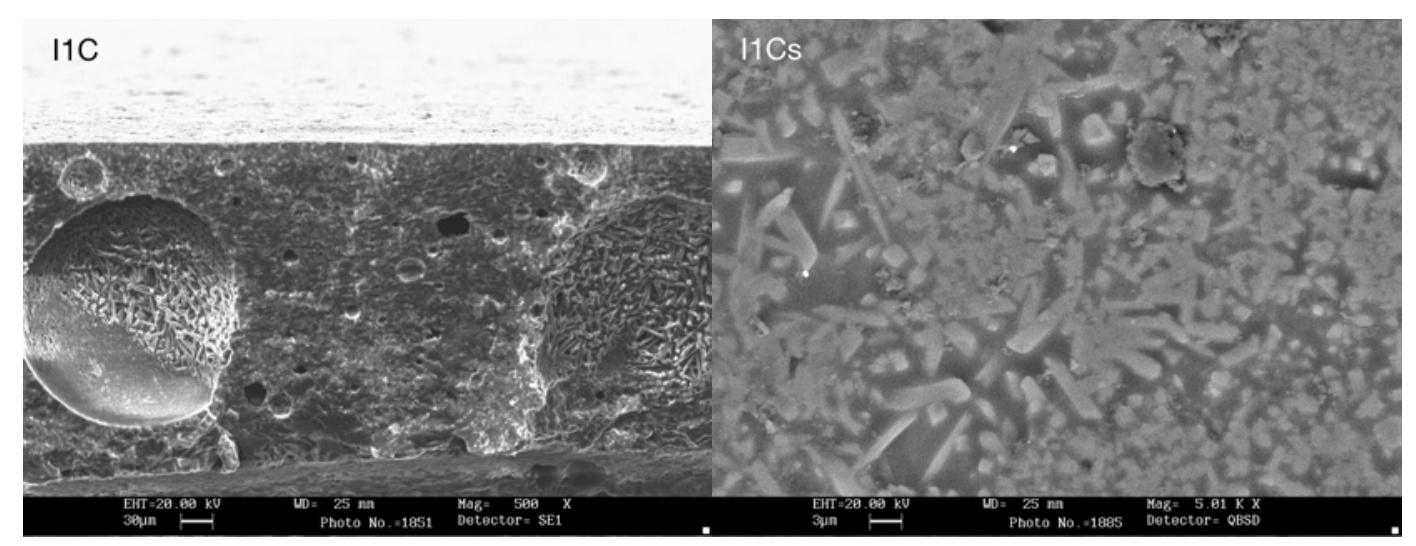

Figura 118 Micrografíes de la composició I1 crua al forn monostrat, a la secció (I1C) i la superfície (I1Cs). 
Finalment, es realitza la comparativa amb les micrografies obtingudes de la secció de peces tractades amb radiació làser. A la Figura 119 es pot comprovar com la capa fosa, d'uns 10 micròmetres d'espessor, cobreix una estructura àmpliament cristal·litzada, com es veu als anàlisis per DRX, que travessa aquesta capa i detecta aquestes fases formades. A la superfície, a la Figura 120, observem la superfície fossa sobre les agulles cristal-lines:

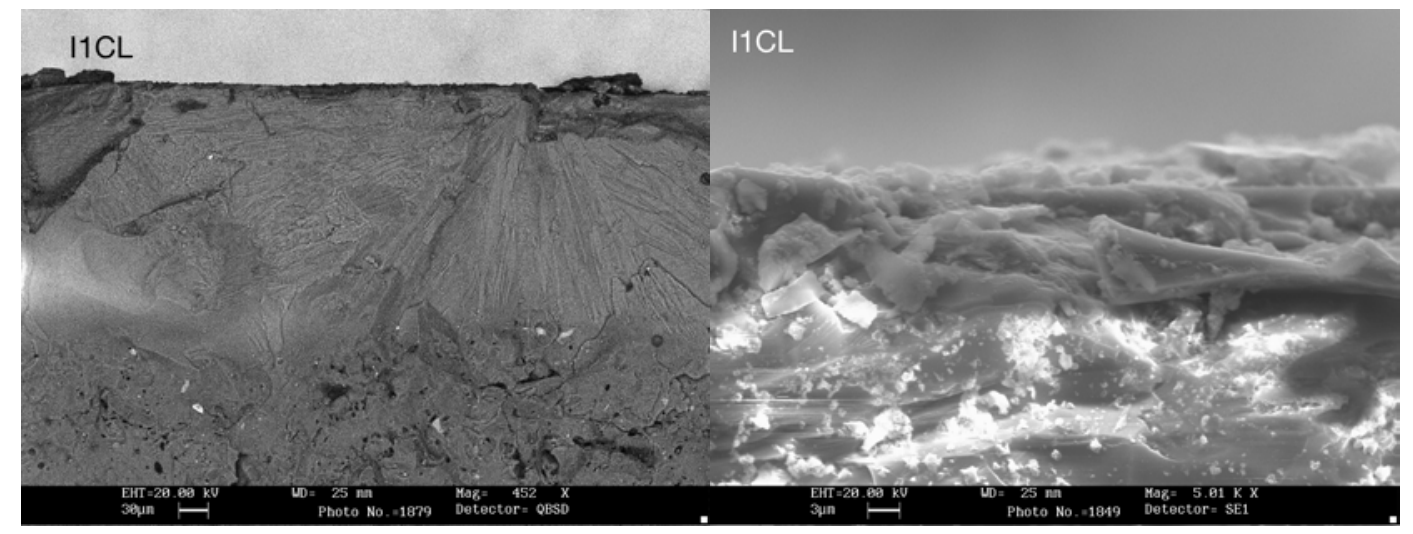

Figura 119 Micrografíes de la secció de la composició I1 tractada amb radiació làser a la superfície d'un esmalt sense fritar.

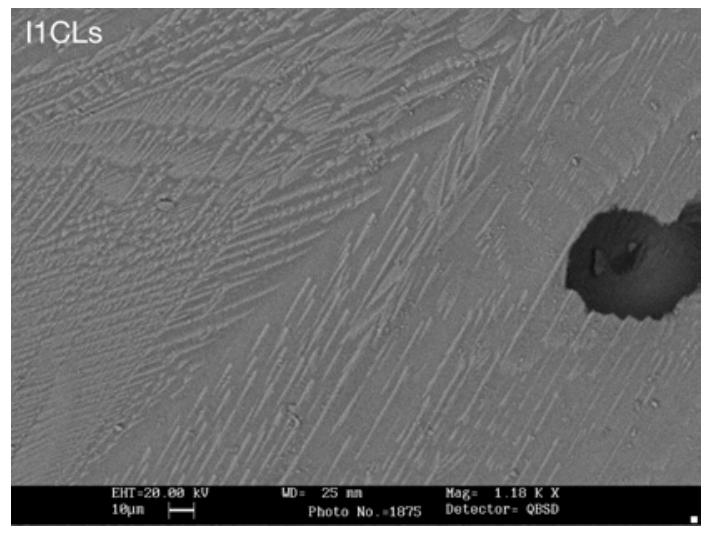

Figura 120 Micrografía de la superfície de la composició I1 tractada amb radiació làser sobre un esmalt sense fritar.

En aquest cas, com ja s'havia comprovat que les fases cristal-lines es formen massivament durant l'escalfament, el fet d'aplicar la radiació a la zona de cocció, fa que els cristalls de la superfície fonguen i que el vidriat presente una superfície més llisa i brillant, a l'estar recoberta per una fina capa de fase vítria.

També s'han realitzat unes anàlisis EDX de les superfícies de les peces, per poder comparar les fases evaporades en cada cas. Es presenten les composicions químiques a la Taula 51. 
Taula 51 Microanàlisis per dispersió d’energies de raigs X de les peces de composició I1, I1C i I1CL.

\begin{tabular}{|cc|c|c|}
\hline Fórmula & I1 & I1C & I1CL \\
\hline $\mathrm{SiO}_{\mathbf{2}}$ & $\mathbf{5 5 , 6 0}$ & $\mathbf{5 2 , 5 7}$ & $\mathbf{5 8 , 8 4}$ \\
$\mathrm{Al}_{2} \mathrm{O}_{3}$ & 3,39 & 7,43 & 8,04 \\
$\mathbf{C a O}$ & $\mathbf{2 2 , 2 4}$ & $\mathbf{1 8 , 0 1}$ & $\mathbf{1 5 , 3 7}$ \\
$\mathrm{FeO}$ & 5,41 & 7,52 & 5,58 \\
$\mathrm{Na} 2$ & $\mathbf{0}$ & $\mathbf{5 , 4 6}$ & $\mathbf{7 , 1 5}$ \\
$\mathrm{MgO}$ & 13,36 & 9,00 & 5,03 \\
\hline
\end{tabular}

En principi, el contingut en calci fa intuir que ha augmentat la quantitat de fase vítria a la superfície, ja que els cristalls contenen una proporció major d'aquest element.

L'eix de la radiació de les anàlisis DRX travessen varies micròmetres la superfície, de manera que per a poder quantificar i visualitzar el canvi de fase, es realitza una anàlisis d'incidència, on es pot observar com, en modificar l'angle de la radiació, també varia l'intensitat de la difracció, fins a desaparèixer per a angles molt menuts, com s'observa a la Figura 121.

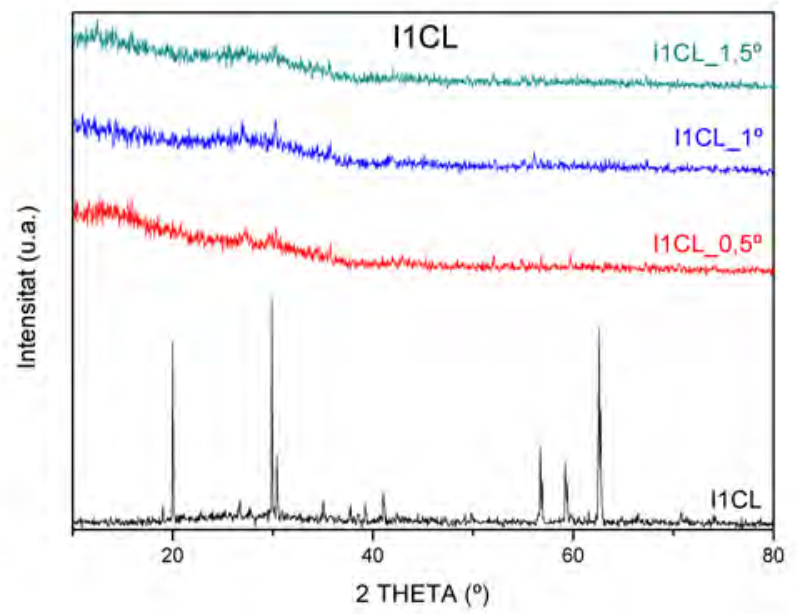

Figura 121 Difractograma d'incidència de la composició I1CL. 


\subsubsection{Composició I2.}

En primer lloc es mostren les imatges de les peces, on I2 és la composició fritada, I2C la composició crua sense aplicació de làser, i I2CL, la composició crua tractada amb làser a la Figura 122.

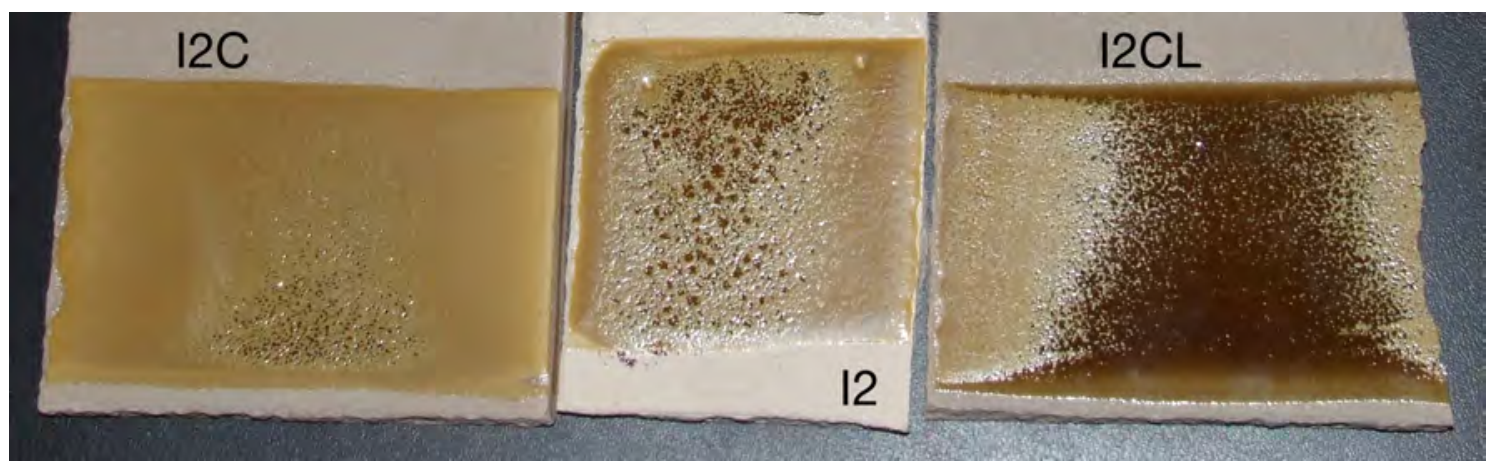

Figura 122 Peces de les composicions 12 , I2C i I2CL cuites al forn monostrat.

Tot i que aquesta composició i la I1 són molt paregudes químicament, s'ha trobat un resultat front a la radiació un poc diferent, degut a la variació de la temperatura de cristal·lització i l'espessor de la capa, major a la composició I2.

La capa de vidre superficial formada en aquest cas és molt menor, i molt més heterogènia, com es pot apreciar a la imatge. Hi ha zones on, tot i haver estat irradiades, la superfície apareix cristal-litzada, i a la zona central, on la quantitat d'esmalt dipositada en cru era menor, es troba una capa de vidre sobre els cristalls.

En aquesta composició s'ha centrat en la zona irradiada però que no presenta fase vítria superficial, per a poder comparar amb els resultats obtinguts a l'altra composició. A continuació mostrem les anàlisis DRX de un tros de vidriat I2CL de la zona dels extrems de la peça obtinguda, que no presenta fase vítria superficial, a la Figura 123: 


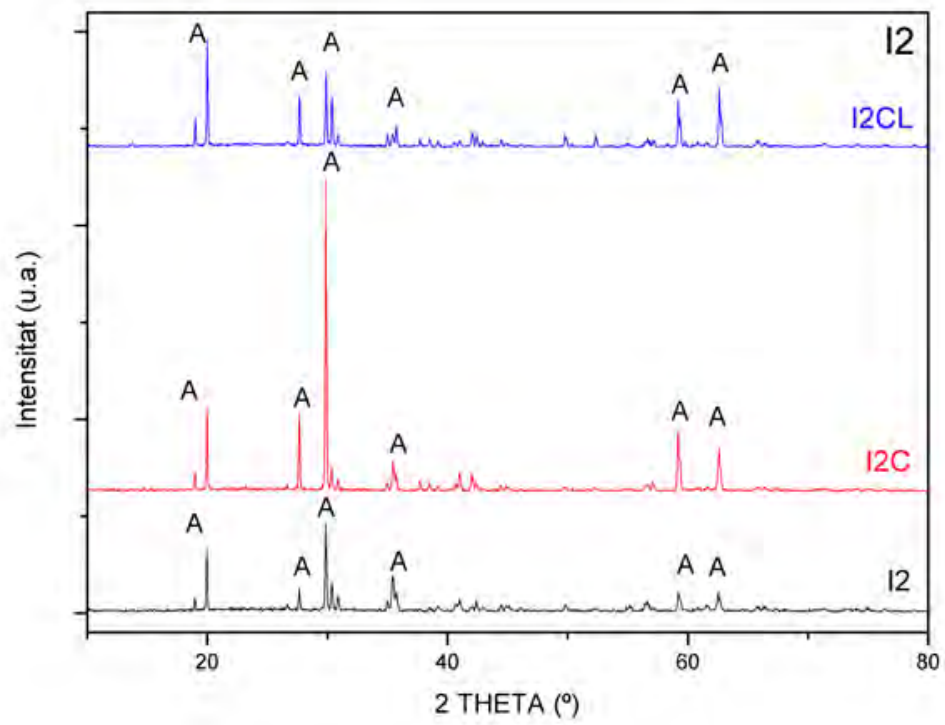

Figura 123 Difractograma de la composició 12 al forn monostrat.

En aquest cas, tot i que la superfície també presenta un aspecte fi i brillant, les fases trobades se pareixen molt més entre la superfície de la peça sotmesa a radiació làser i la superfície de la composició fritada. Els canvis d'orientació que apareixen a la composició I1 no són tant evidents en aquest cas. A la figura es pot comprovar com no s'aprecia la fase fosa a la cara superior, provocada per la radiació del làser, a la Figura 124.

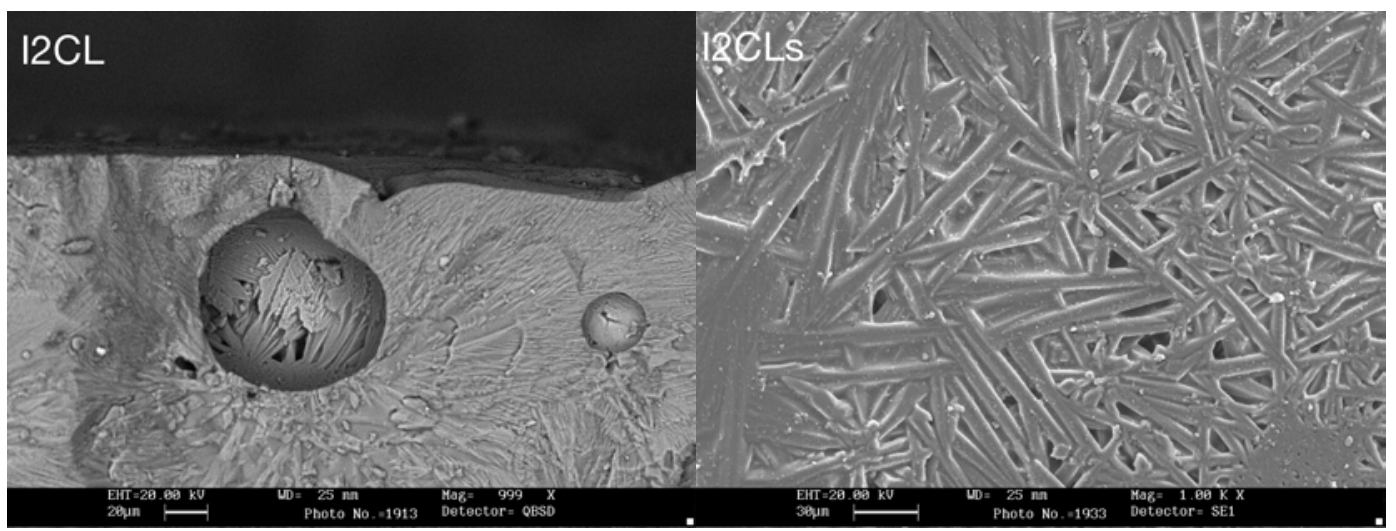

Figura 124 Micrografies de la secció (I2CL) i la superfície (I2CLs) d'un vidriat I2C al que s'ha aplicat radiació làser.

A la vora de la superfície, per aquesta part, es pot comprovar com s'han format cristalls molt menuts a la zona irradiada, que li donaran gran resistència mecànica i química, com s'observa a la Figura 125. 


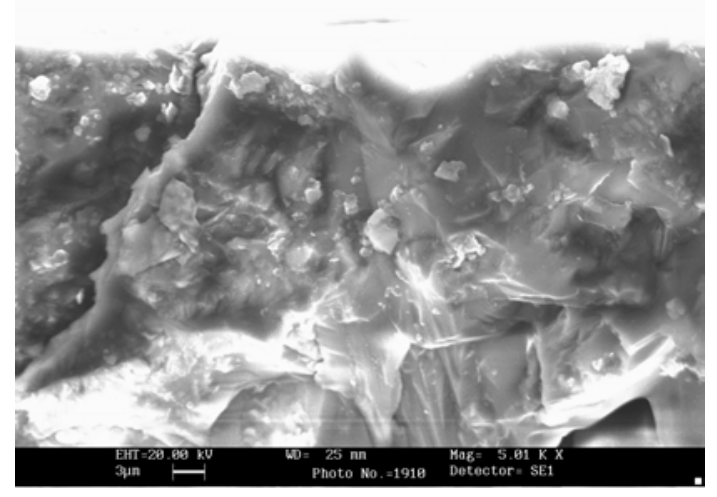

Figura 125 Micrografia de la secció d’un vidriat de la composició 12 al que s'ha aplicat radiació làser.

Finalment, s'han realitzat anàlisis EDX de la superfície, amb la idea de poder comparar les fases evaporades entre les composicions I1 i I2. Es presenten les composicions químiques a la Taula 52.

Taula 52 Microanàlisis per dispersió d’energies de raigs $X$ de les peces de composició I1CL i I2CL.

\begin{tabular}{|c|c|c|}
\hline Fórmula & I1CL & I2CL \\
\hline $\mathrm{SiO}_{\mathbf{2}}$ & $\mathbf{5 8 , 8 4}$ & $\mathbf{5 2 , 6 4}$ \\
$\mathrm{Al}_{2} \mathrm{O}_{3}$ & 8,04 & 8,00 \\
$\mathbf{C a O}$ & $\mathbf{1 5 , 3 7}$ & $\mathbf{1 8 , 4 9}$ \\
$\mathrm{FeO}$ & 5,58 & 9,67 \\
$\mathrm{Na}_{2} \mathrm{O}$ & $\mathbf{7 , 1 5}$ & $\mathbf{4 , 0 2}$ \\
$\mathrm{MgO}$ & 5,03 & 7,21 \\
\hline
\end{tabular}

Si es té en compte la composició inicial, es pot comprovar com la composició química que es detecta amb les anàlisis, pareix indicar també que a la superfície hi ha més fase cristal·lina d'augita a la composició I2 que a la composició I1.

Per a comprovar que hi ha poca superfície vítria recobrint els cristalls, es fa també una anàlisis d'incidència, que demostra que la capa formada és molt inferior en la superfície analitzada de la composició I2. A la Figura 126, es comprova com els picus d'augita es mantenen, en menor intensitat, a l'augmentar l'angle d'incidència. 


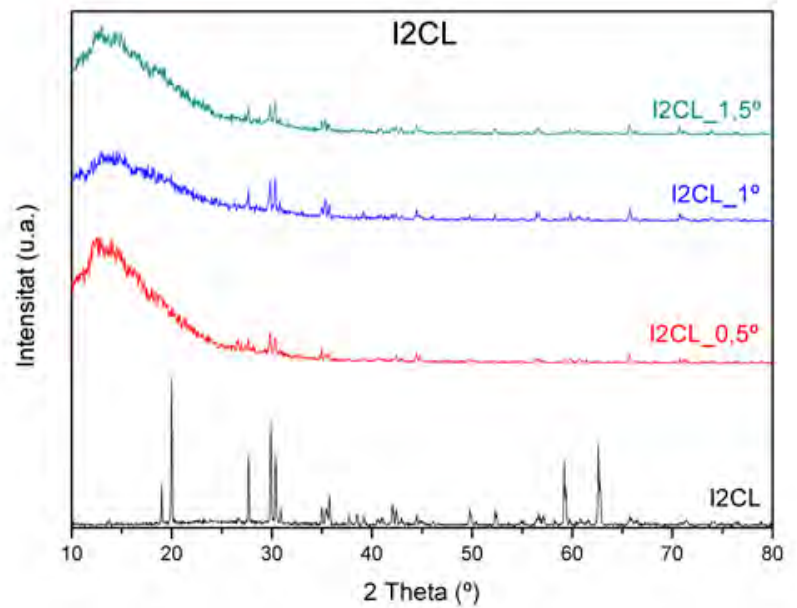

Figura 126 Difractograma d'incidència de la composició I1CL. 


\subsubsection{Composició J1.}

En primer lloc, es presenten les imatges dels vidriats obtinguts en aquest cicle de cocció

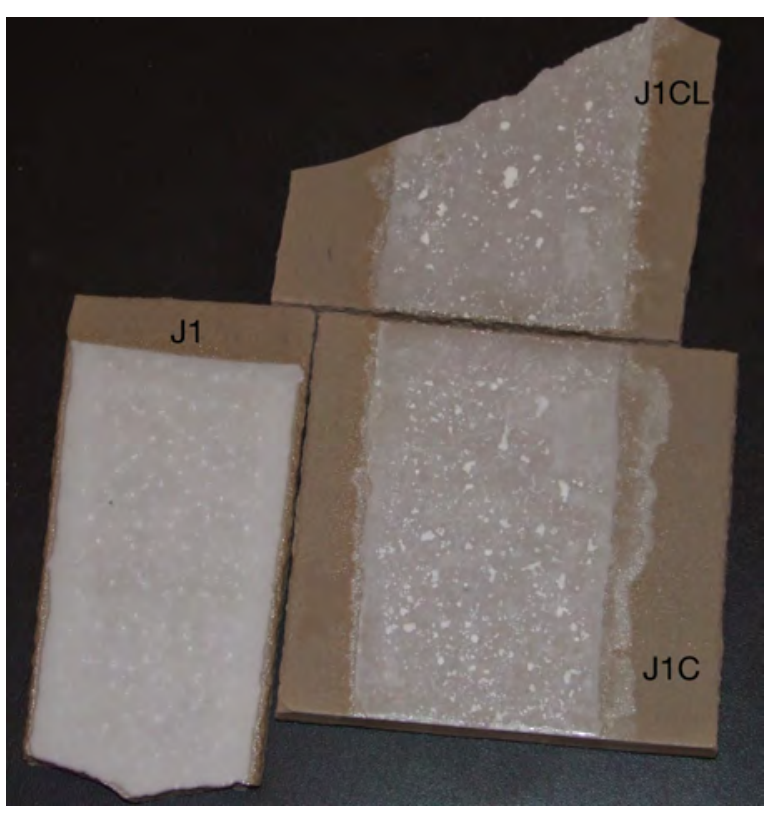
a la Figura 127, on es pot comprovar que presenta un bon estirament i té un aspecte opac i brillant.

Com fins ara, les referències emprades són $\mathbf{J 1}$ per a la composició fritada, J1C per a la composició crua sense aplicació de làser, i J1CL, per a la composició crua tractada amb làser.

A la imatge també es pot observar l'aspecte brut de la superfície que ve donat per la cristal-lització de la hidrotungstita damunt del vidriat, molt més accentuada a les peces obtingudes a partir d'esmalts sense fritar.

Figura 127 Peces de les composicions J1, J1C i J1CL cuites al forn monostrat.

A la Figura 128 es mostren els resultats de les anàlisis per DRX de les peces passades per el forn monostrat amb làser incorporat. En aquest cas, en arribar a temperatures més altes la superfície de la peça durant la cocció, sembla que augmente la quantitat de scheelita a la superfície, que pràcticament no es detecta a les superfícies sense fritar en aquesta cocció.

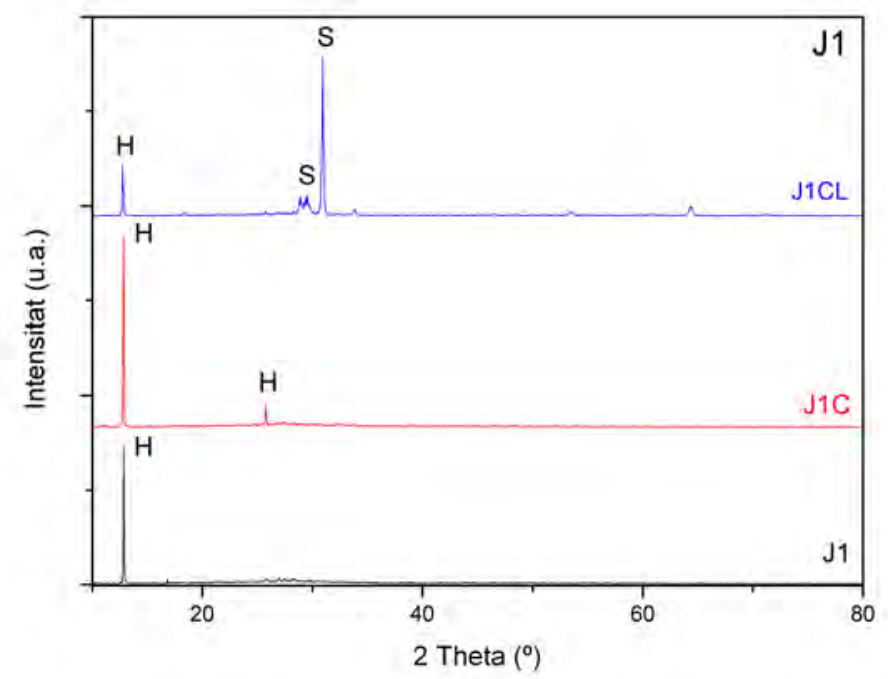

Figura 128 Difractograma de la composició J1 al forn monostrat. 
El problema radica en què, com la hidrotungstita es genera sobre la superfície, és possible que emmascare l'altra fase cristal·lina, cosa que implica que els resultats no siguen concloents. A continuació, es presenten unes imatges on es pot observar clarament com creix aquesta fase en les irregularitats que hi ha a les peces, a la Figura 129.

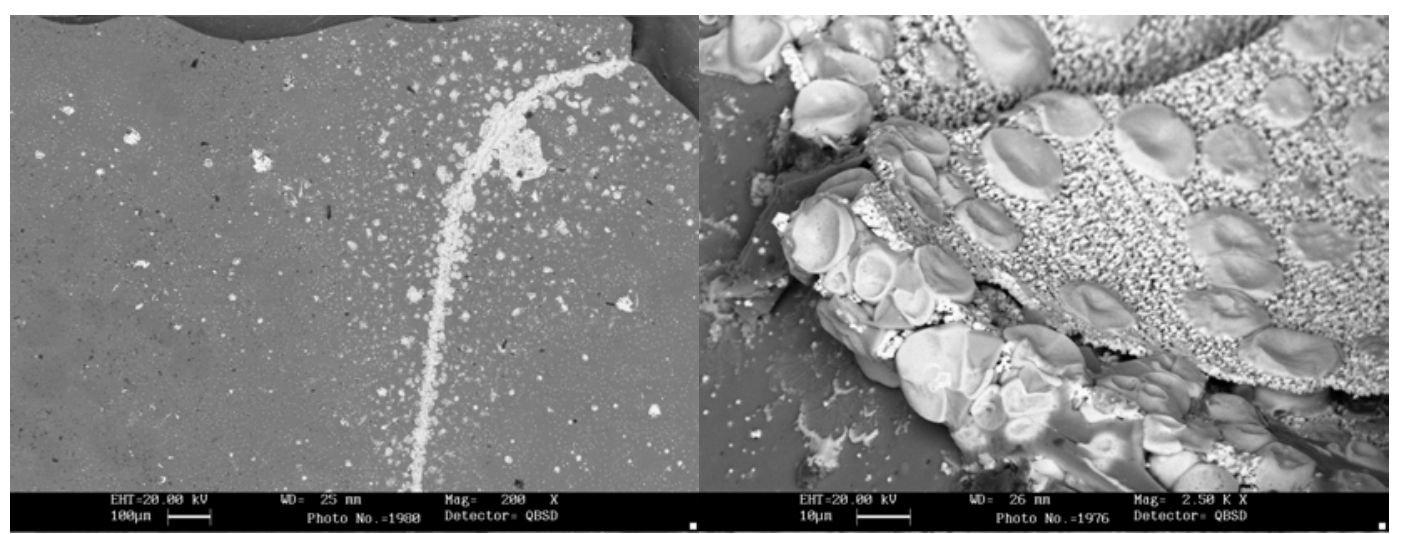

Figura 129 Micrografíes de la composició J1 on s'observa el creixement de la hidrotungstita.

Si s'observen les micrografies de la peça crua, a la Figura 130, es veu una estructura similar a les estudiades fins ara, amb cristalls de scheelita a l'interior i a la superfície.

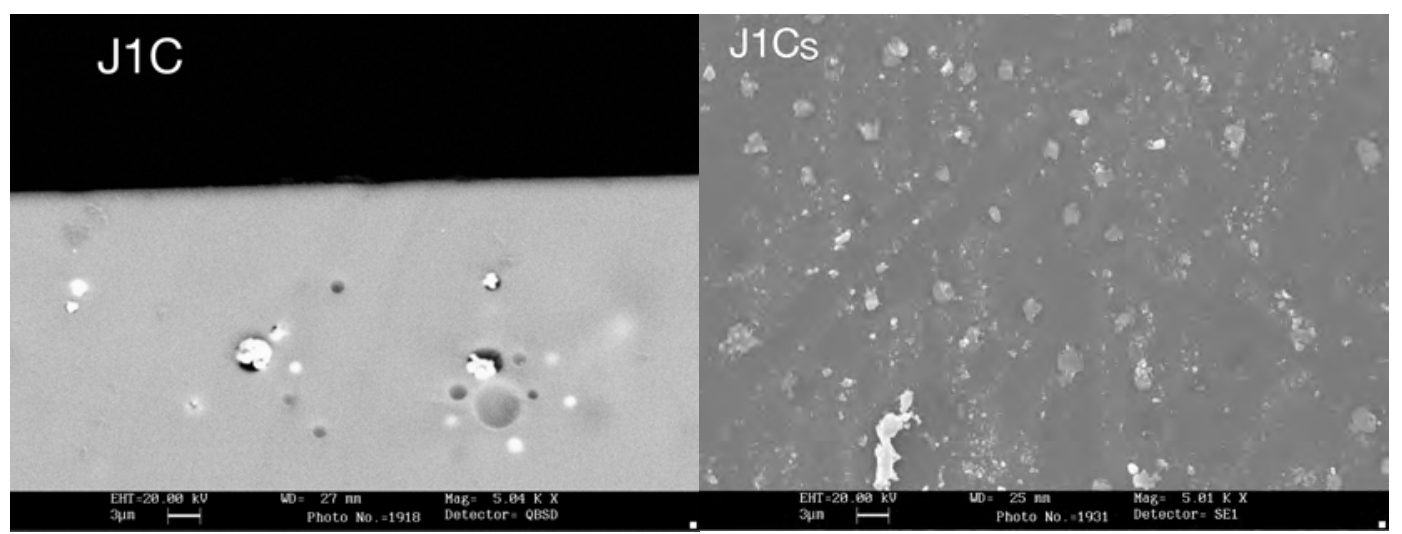

Figura 130 Difractograma de la secció (J1C) i la superfície (J1Cs) d'una peça de composició J1C a la que se li ha aplicat radiació làser.

A continuació s'observa la secció i la peça tractada amb làser, a la Figura 131, on s'aprecia clarament la zona tractada amb retrodispersors, ja que no hi ha fases cristal·lines en aquesta capa. Per tant, el vidriat té una capa fosa per damunt de les fases cristal·lines, com passava amb les composicions A1 i I1. 
RECERCA DE NOUS VIDRIATS, FORMULATS A PARTIR DE RESIDUS, I OBTINGUTS PER MITJÀ DE NOVES TECNOLOGIES DE PROCESSAT CERÀMIC

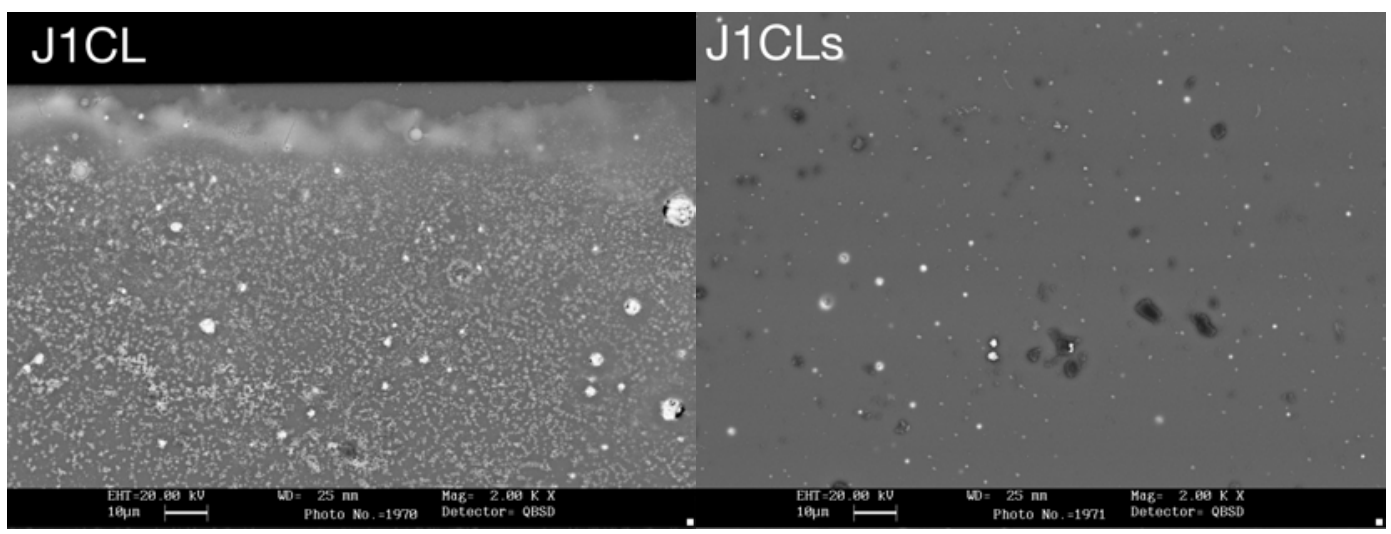

Figura 131 Difractograma de la secció (J1CL) i la superfície (J1CLs) d'una peça de composició J1C a la que se li ha aplicat radiació làser. 


\subsubsection{Composició J3.}

En primer lloc presentem les imatges de la composició $\mathbf{J 3}$, on es pot comprovar com aquest esmalt està molt punxat, tot i que brilla, i presenta un aspecte totalment opac, com s'observa a la Figura 132. Es continua amb l'estudi tècnic destacant que cal ajustar el cicle de cocció per tal d'obtenir una estirada adequada i sense defectes. Les referències emprades són $\mathbf{J 3}$, la composició fritada, $\mathbf{J 3 C}$, la composició crua sense aplicació de làser, i J3CL, la composició crua tractada amb làser.

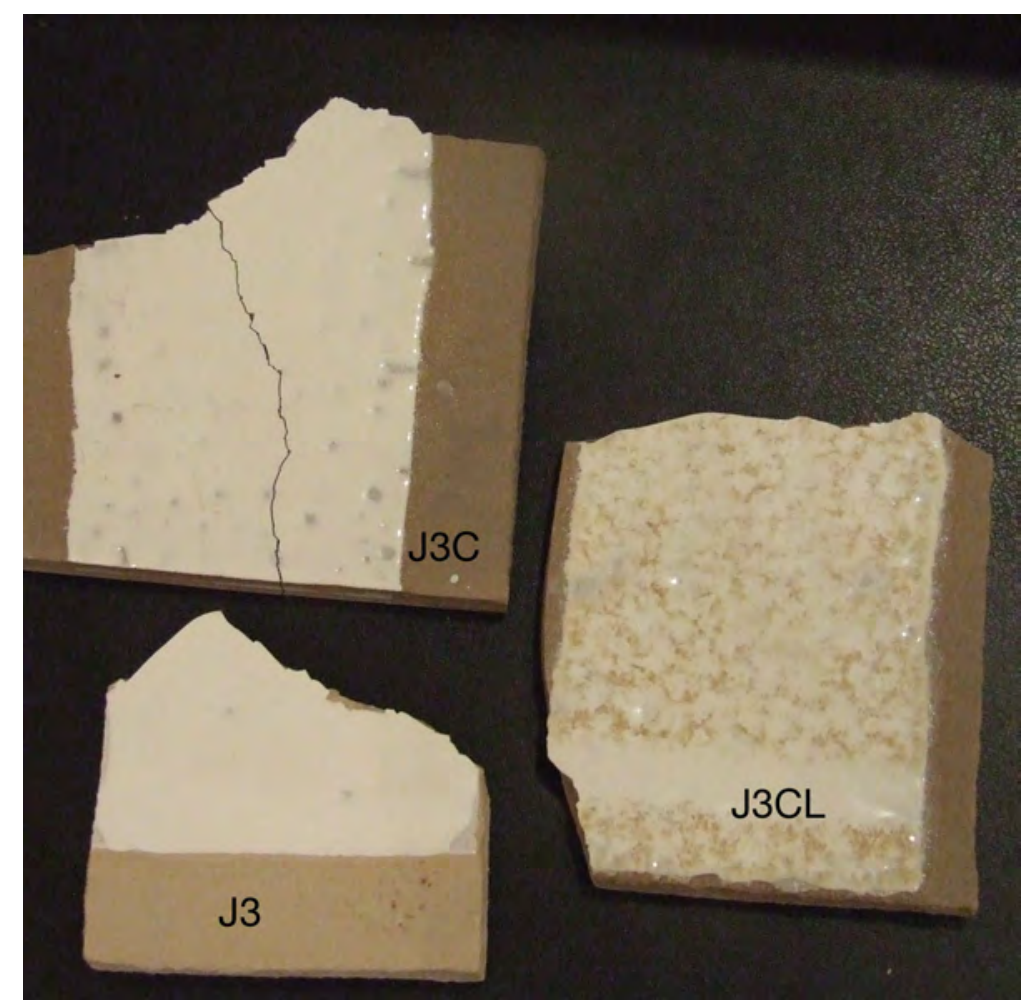

Figura 132 Peces de les composicions J3, J3C i J3CL cuites al forn monostrat.

A continuació es mostra el resultat de les anàlisis DRX de la superfície dels vidriats passats per el forn monostrat amb làser incorporat, a la Figura 133. En quantificar els resultats, s'obté que totes les cristal·litzacions estan per damunt del $\mathbf{9 5 \%}$, amb la qual cosa no són apreciables les modificacions. 


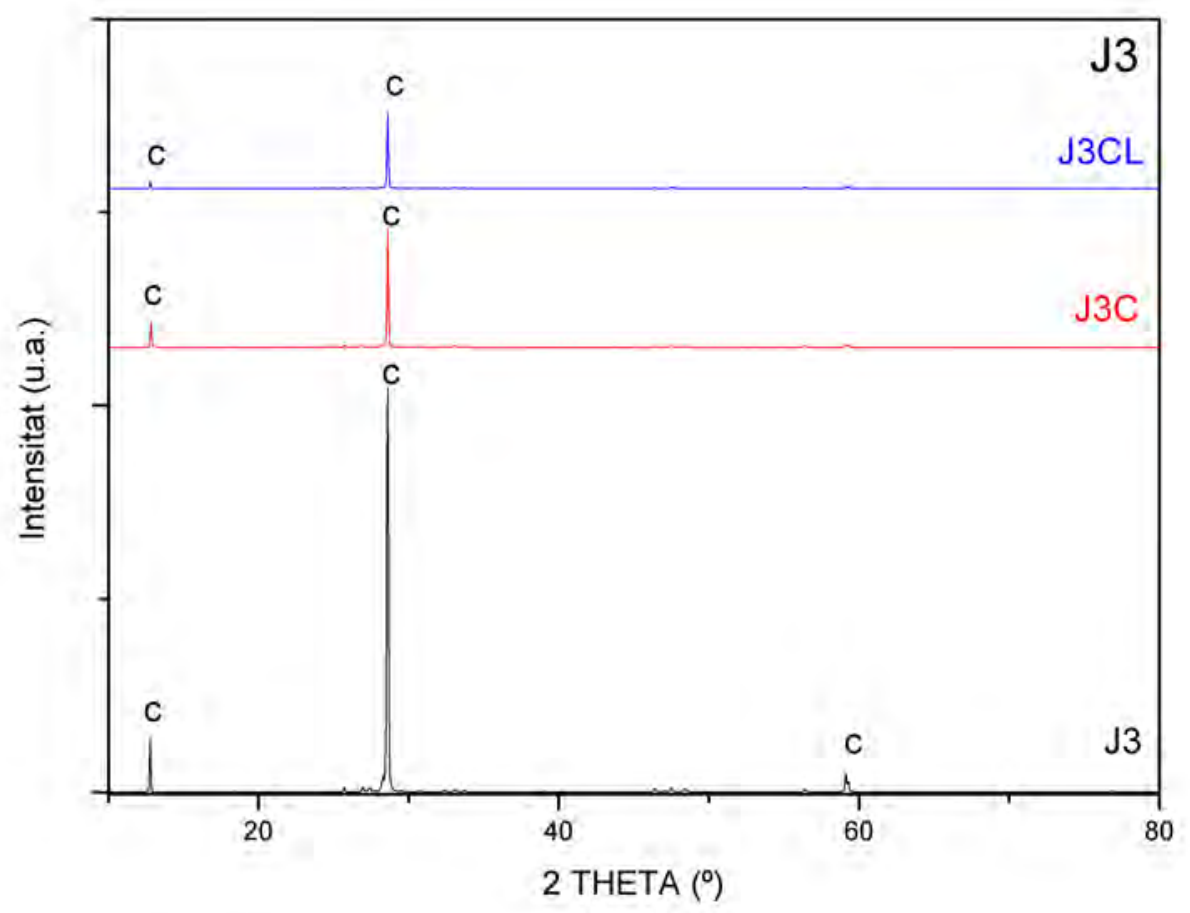

Figura 133 Difractograma de la composició J3 al forn monostrat.

Si s'observa la microestructura a la Figura 134, no es veu ni la fase fosa ni acumulacions a la superfície. Es troba un aspecte similar a les superfícies obtingudes en totes les proves anteriors d'aquesta composició.

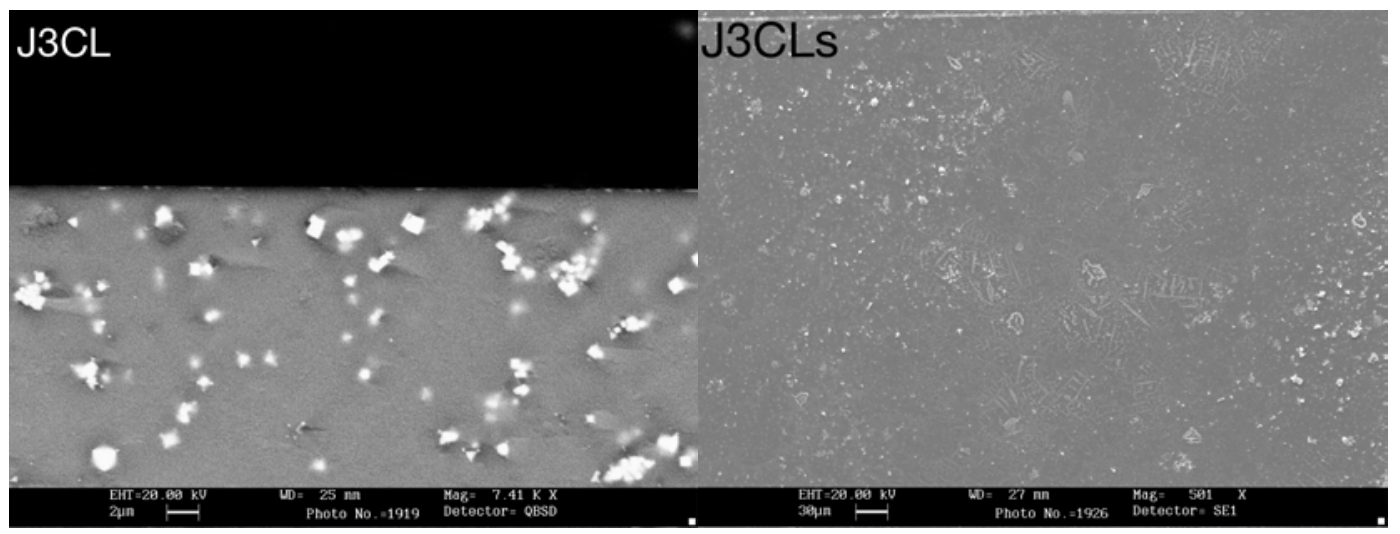

Figura 134 Micrografies de la secció (J3CL) i la superfície (J3CLs) d'una peça de composició J3 a la que s’ha aplicat radiació làser.

En aquest cas, la composició $\mathbf{J 3}$ no presenta modificacions molt grans a l'aplicar la radiació làser en aquestes condicions. 


\subsubsection{Estudi dels vidriats acolorits i serigrafiats.}

\subsubsection{Vidriats acolorits:}

En primer lloc es vol destacar que com les proves s'han realitzat sobre l'esmalt $\mathbf{J 3} \mathrm{i}$ J3C, a la Figura 135, presenten un aspecte punxat, molt deteriorat. Per tant, es continua amb l'estudi tècnic, tot i ser conscients que cal ajustar el cicle de cocció perquè la calor absorbida per l'esmalt siga adequada.

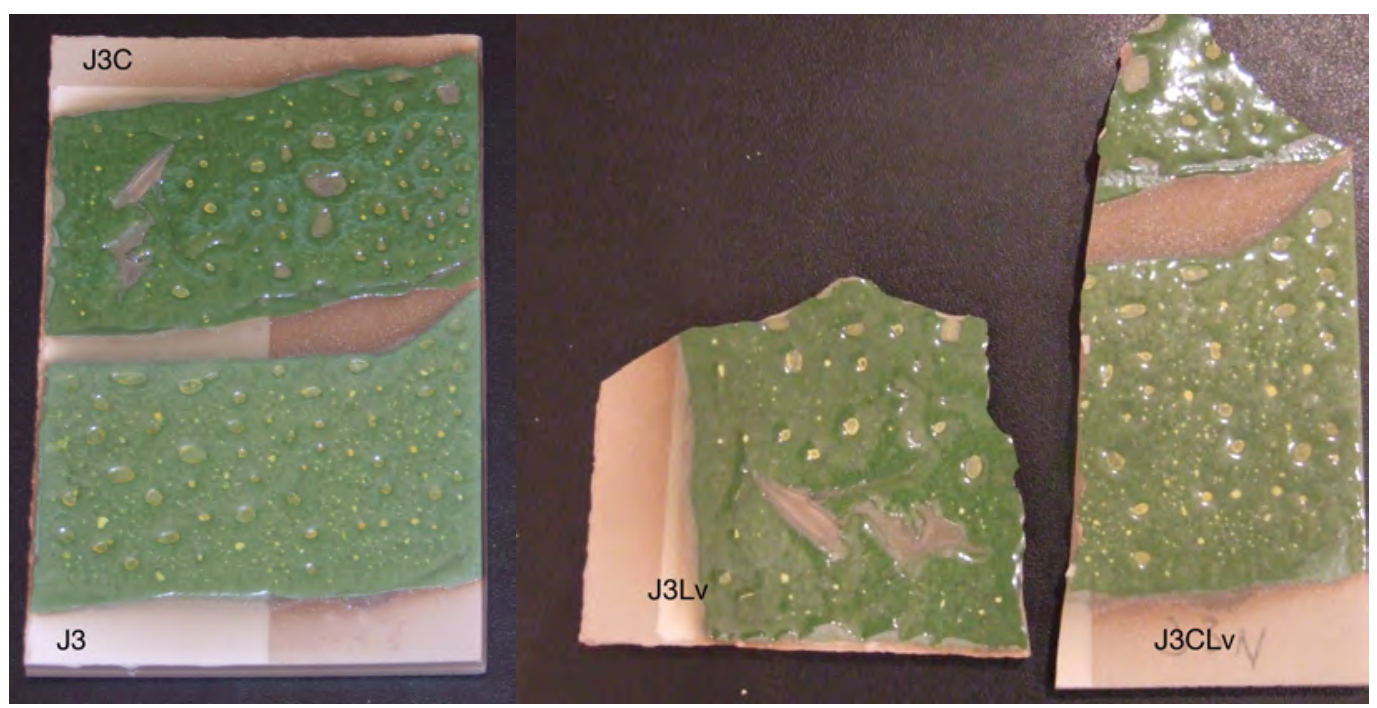

Figura 135 Peces de les composicions J3V i J3CV cuites al forn monostrat.

Després, a la Figura 136, s'observa com la superfície dels vidriats als que no s'ha aplicat la radiació presenten el mateix aspecte, a diferents augments. En tots els casos s'aprecien partícules menudes de cerianita i partícules més grosses, que són els pigments, envoltats de fase cristal-lina, sobre un vidriat amb una composició menys pesada. També s'aprecien els punxats, presents a totes les superfícies, tot i que pareix que hi haja menys quantitat al vidriat amb l'aplicació làser.

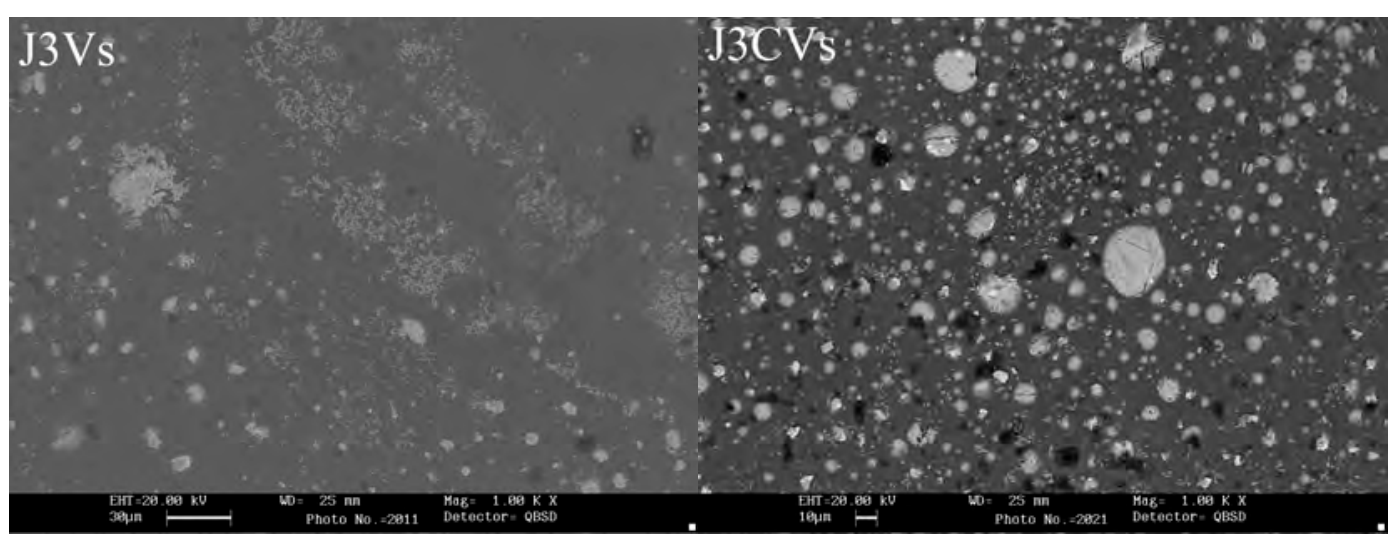

Figura 136 Micrografíes de la superficie de les composicions J3 acolorida (J3Vs) i la J3C acolorida (J3CVs). 
A continuació es presenten les imatges obtingudes amb SEM, on es pot observar les partícules fines de cerianita i unes partícules més grosses, que són les partícules de pigment rodejades per cristall que ha crescut al seu voltant, a la Figura 137.

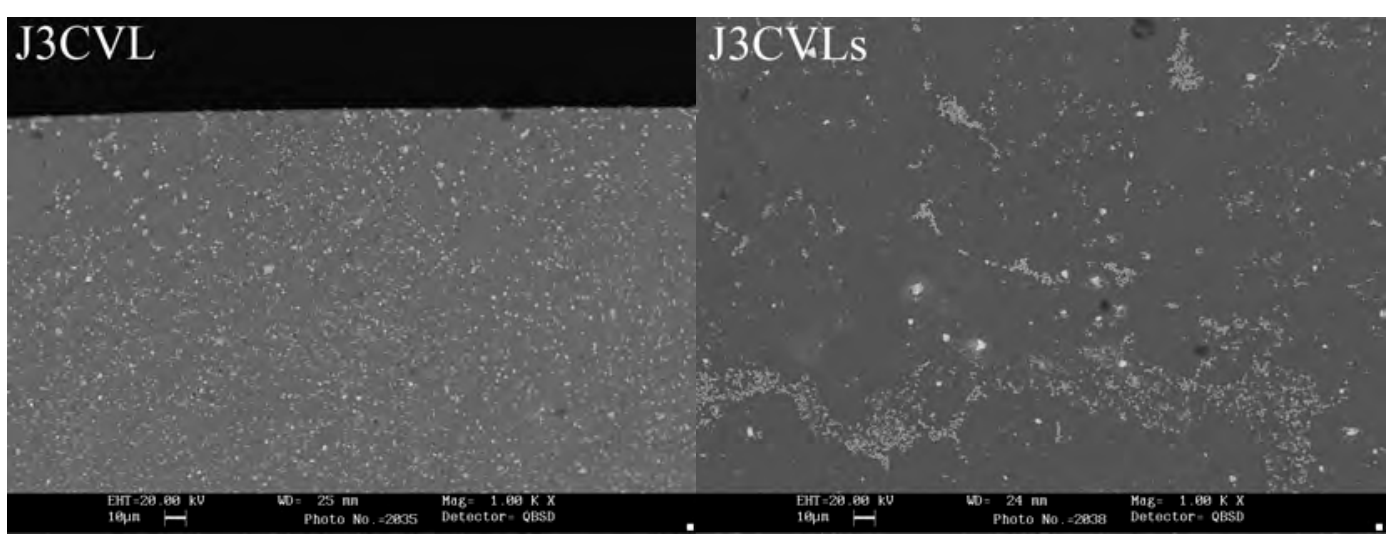

Figura 137 Micrografíes de la composició J3C acolorida i amb aplicació làser a la secció (J3CVL) i la superfície (J3CVLS).

\subsubsection{Vidriat serigrafiat:}

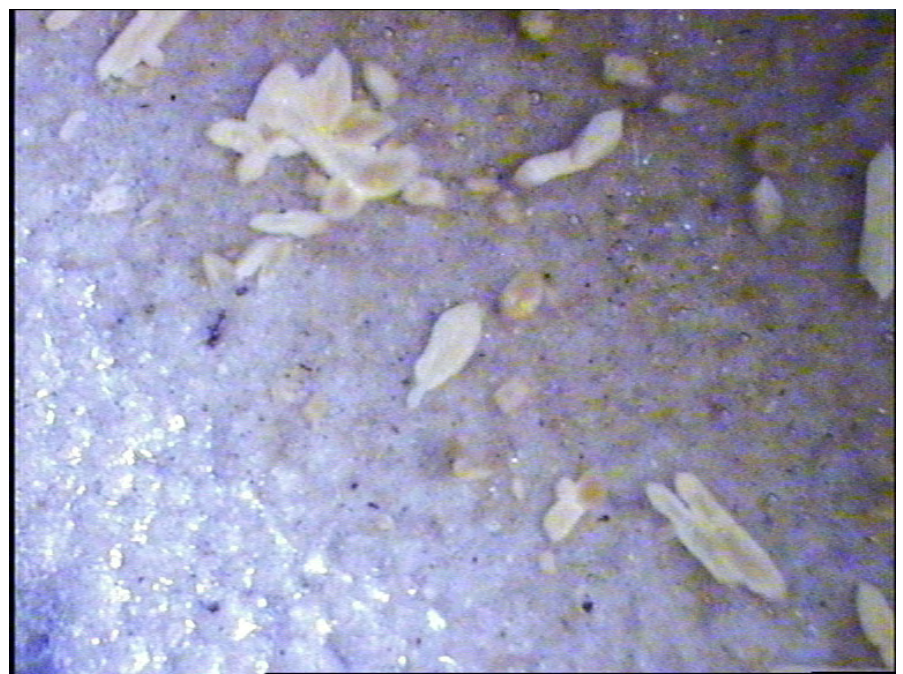

Per a conèixer com es modifica la definició del punt en aplicar la radiació, aquesta s'ha aplicat sobre un dels vidriats una serigrafia amb una pantalla amb molt poc de pas, per a poder veure bé el punt, i s'han estudiat aquests vidriats en microscopi. Es pot comprovar, a la Figura 138, com els punts negres que apareixen a la superfície estan perfectament definits $i$ no es difuminen per la radiació.

Figura 138 Superfície de la composició I1C serigrafiada i amb el làser aplicat. 


\subsubsection{Estudi de les propietats dels vidriats.}

Es mostren els resultats de les anàlisis de microduresa Vickers, resistència química $\mathrm{i}$ propietats bactericides a les composicions cuites al forn monostrat.

\subsubsection{Microduresa Vickers.}

En primer lloc s'han estudiat els resultats obtinguts dels assajos de microduresa Vickers (Hv) per a les composicions al cicle del forn monostrat, que es presenten a la Taula 53.

Taula 53 Resultats dels assajos de microduresa Vickers, part 1.

\begin{tabular}{|l|l|l|l|l|l|l|l|l|l|l|l|l|}
\hline & A1 & A1C & A1CL & B1 & B1C & B1CL & E1 & E1C & E1CL & J1 & J1C & J1CL \\
\hline Hv (Gpa) & 5,0 & 3,9 & 4,4 & 4,5 & 4,8 & 4,4 & 5,0 & 5,3 & 4,0 & 4,2 & 4,0 & 4,4 \\
\hline desvest & 0,3 & 0,1 & 0,4 & 0,2 & 0,5 & 0,4 & 0,4 & 0,2 & 0,8 & 0,3 & 0,4 & 0,3 \\
\hline
\end{tabular}

D'aquesta sèrie, realitzada amb una càrrega de $\mathbf{4 , 9 N}$, destaca que la superfície de les composicions E1 estan tant punxades que és difícil de mesurar, sobre tot la E1CL. A continuació, es poden veure els resultats de la resta de vidriats estudiats a la Taula 54.

Taula 54 Resultats dels assajos de microduresa Vickers, part 2.

\begin{tabular}{|l|l|l|l|l|l|l|l|l|l|}
\hline & I1 & I1C & I1CL & I2 & I2C & I2CL & J3 & J3C & J3CL \\
\hline Hv (Gpa) & 5,4 & 5,8 & 4,9 & 11,8 & 4,7 & 15,5 & 13,5 & 12,4 & 12,9 \\
\hline desvest & 1,0 & 0,7 & 0,9 & 6,8 & 1,9 & 11,4 & 2,5 & 4,4 & 1,5 \\
\hline
\end{tabular}

Aquestes mesures s'han realitzat amb una càrrega de $\mathbf{2 , 9 4 N}$ en el cas de la serie $\mathbf{I 1}$, de 4,9N per a les composicions $\mathrm{I} 2 \mathrm{i}$ I2C, i amb una càrrega de $\mathbf{9 , 8} \mathrm{N}$ per a les mesures de la sèrie $\mathbf{J 3}$ i la composició I2CL. Alguns d'aquests valors són molt superiors, com correspon als materials vitroceràmics, entre 5 i 6,9, o inclús majors [88][116][117]. Destaquen els valors més baixos de la composició I1CL, degut a la capa de fase vítria que cobreix la superfície cristal-litzada. A més, cal destacar que tot i que la superfície I2CL presenta els valors més alts, la superfície és molt irregular i la desviació estàndard és també la major. En canvi, tots els vidriats derivats de la composició J3 són molt alts $\mathrm{i}$ molt més similars entre ells. 


\subsubsection{Resistència química.}

A continuació es presenten els resultats dels assajos de resistència química. Totes les peces de les sèries A1, B1, I2, J1 i J3 passen la prova de resistència química a l'àcid clorhídric al 18\% segons la norma ISO 10545, obtenint la classificació GHA. Les sèries E1 i I1 han de classificar-se d'un altra manera, ja que presenten una superfície tant punxada que no és possible la classificació normal. Totes es classifiquen GHA(v), sense defectes visibles, excepte la $\mathbf{I 1 C L}$, que està clarament deteriorada, amb pèrdua d'esmalt a la superfície.

Per tant, a la vista d'aquests resultats, podem concloure que la aplicació de radiació làser sobre els esmalts a les condicions emprades, sols empitjora les propietats finals dels vidriats en alguns casos, mentre que en altres les deixa igual o les millora.

\subsubsection{Propietats bactericides.}

Finalment, es comenten els resultats dels assajos bactericides. S'han sembrat microorganismes E. Coli a la superfície de la composició J3C, a la Figura 139, i microorganismes Stapliococcus sp. a les superfícies de composició J3 i J3CL. S'ha deixat incubar 24 hores a una temperatura òptima per al microorganisme i s'ha estudiat el creixement respecte de l'estàndard.

A continuació s'ha realitzat una extracció amb brou de cultiu, observant-se una disminució respecte de l'estandar (B1) del creixement d'E. Coli. En canvi, l'altre microorganisme, el Stapliococcus sp., ha tingut un creixement normal en les dues superfícies, tant en la tractada amb radiació làser com en la fritada.

Per tant es pot concloure que, a falta de proves quantitatives, el vidriat J3, que conté ceri a la seva composició, té propietats bactericides amb el microorganisme E. Coli, però no amb l'Stapliococcus sp.

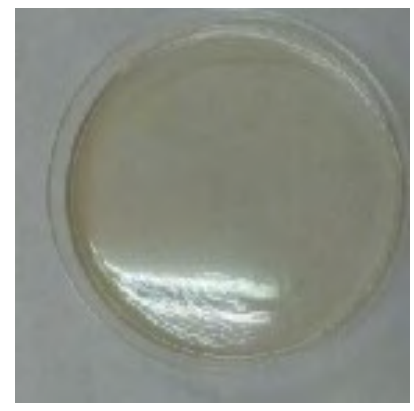

Figura 139 Cultiu de bacteries. 
Capítol V. Conclusions 


\section{Conclusions.}

- S'han formulat esmalts vitroceràmics amb percentatges elevats de residus industrials, valoritzant-los, i que donen rendiments cristal-lins alts amb cicles industrials estàndards per a la fabricació de taulells ceràmics.

- Les composicions vitroceràmiques I1 i I2 formen cristalls durant 1'escalfament que no són dissolts en arribar a la màxima temperatura, de manera que la influència del temps i temperatura de refredament són molt limitades en aquestes composicions.

- S'han optimitzat les variables de cocció del forn monostrat amb làser per aconseguir vidriats amb bones propietats tècniques.

- L'aplicació de radiació làser sobre l'esmalt durant la cocció pot fondre la superfície de l'esmalt i modificar tant el seu aspecte com les fases observades a la superfície.

- Aquesta radiació pot permetre d'obtenir més fases cristal·lines, en alguns esmalts, que els que s'obtenen a partir del material sense fritar.

- Es poden millorar les propietats tècniques de la superfície dels esmalts a partir de la radiació làser durant la cocció. Aquestes variacions depenen de la quantitat de radiació aplicada i de l'espessor de la capa d'esmalt, entre altres.

- En alguns casos, la utilització de la radiació làser permet estalviar clarament energia i temps total de processat respecte de la producció de peces esmaltades amb esmalts fritats segons el procés tradicional, a més d'aconseguir avantatges econòmics, en permetre l'eliminació de l'etapa de la fase de fritat.

- L'aplicació de radiació làser sols empitjora la microduresa Vickers i la resistència química en els casos on produeix la destrucció de cristalls per damunt de la temperatura de cristal·lització, quan no tenen temps de recristal·litzar.

- L'aplicació de radiació làser no modifica, a les composicions provades, la microestructura obtinguda per la interacció del pigment amb la fase vítria.

- No s'observen modificacions importants de la definició en la decoració aplicada sobre l'esmalt degut a l'aplicació de la radiació làser. 
Capítol V. Conclusions 


\section{Línies futures.}

- Seria interesant provar la modificació del cicle de cocció per tal de provar l'aplicació del làser en un altre punt de l'escalfament de la peça, i acotar les condicions de processat per assegurar l'obtenció de propietats físiques millorades.

- Com que hi ha composicions amb alts continguts en ferro, és convenient realitzar estudis de ferromagnetisme i conductivitat de les composicions més riques en ferro.

- Els primers assajos realitzats són una pinzellada per a poder quantificar els resultats de les sembres bactericides i afegir assajos fungicides a les mateixes o altres composicions.

- Es poden fer estudis sobre l'evolució de la generació de la hidrotungstita a la composició J1 amb el temps, que pot permetre de controlar la seva generació i el seu creixement. 
Capítol VI. Línies futures 


\section{Annexes.}

\subsection{Difractometria làser de les suspensions.}

Per una banda es presenten les gràfiques diferencials en volum de les sèries, i per altra, es presenten en taules els valors que representen un $1 \%$ de rebutjall, és a dir, el $\mathrm{d}_{99}$.

\subsubsection{Sèrie A.}

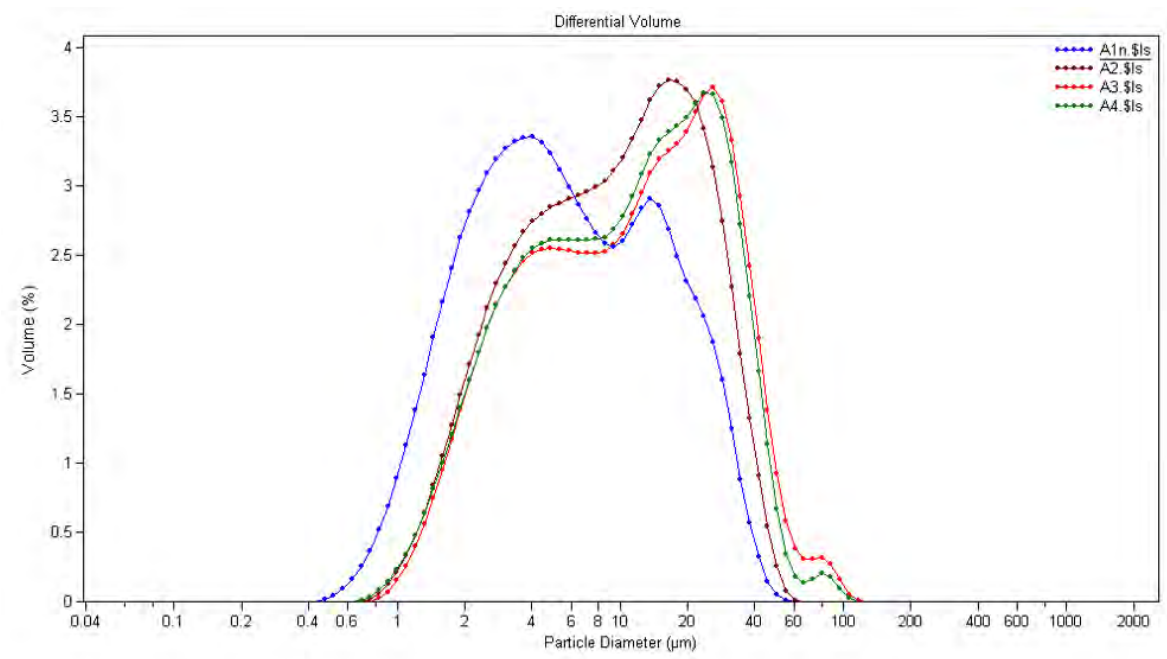

Figura 140 Diagrama diferencial de la granulometria de la sèrie $\mathrm{A}$.

Taula 55 Mesures granulomètriques de la sèrie $A$.

\begin{tabular}{|l|l|}
\hline Mostra & $D_{99}(\mu \mathrm{m})$ \\
\hline A1 & 36 \\
\hline A2 & 42 \\
\hline A3 & 56 \\
\hline A4 & 52 \\
\hline
\end{tabular}




\subsubsection{Sèrie B.}

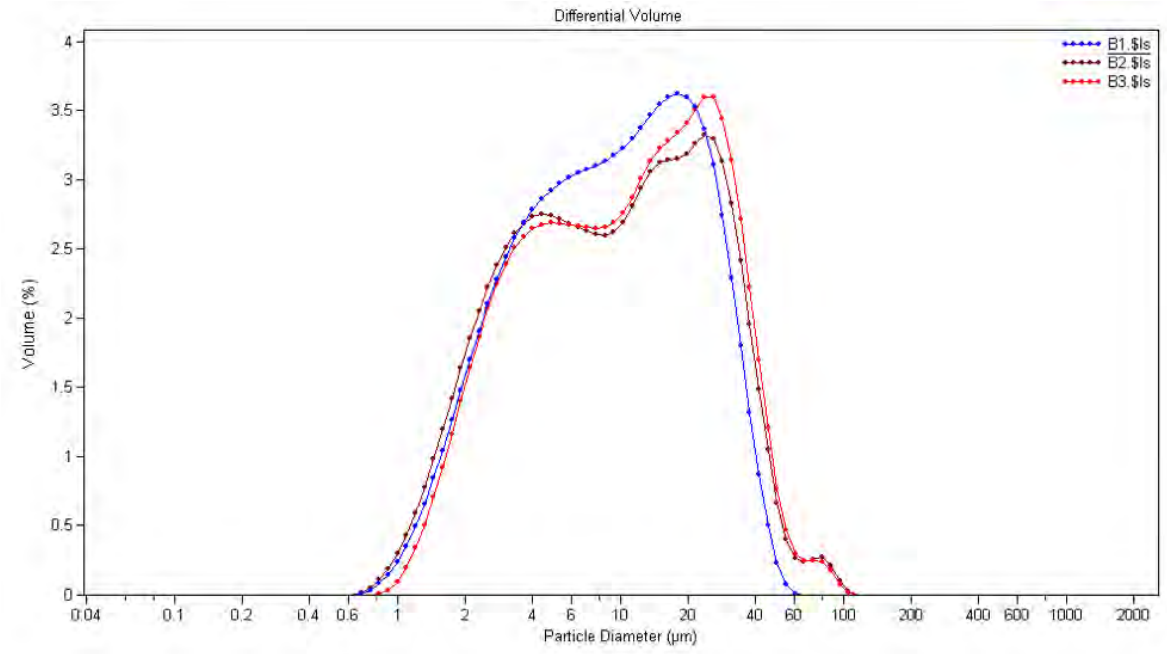

Figura 141 Diagrama diferencial granulomètric de la sèrie $B$.

Taula 56 Mesures granulomètriques de la sèrie $B$.

\begin{tabular}{|l|l|}
\hline Mostra & $D_{99}(\mu \mathrm{m})$ \\
\hline B1 & 40 \\
\hline B2 & 54 \\
\hline B3 & 54 \\
\hline
\end{tabular}

\subsubsection{Sèrie C.}

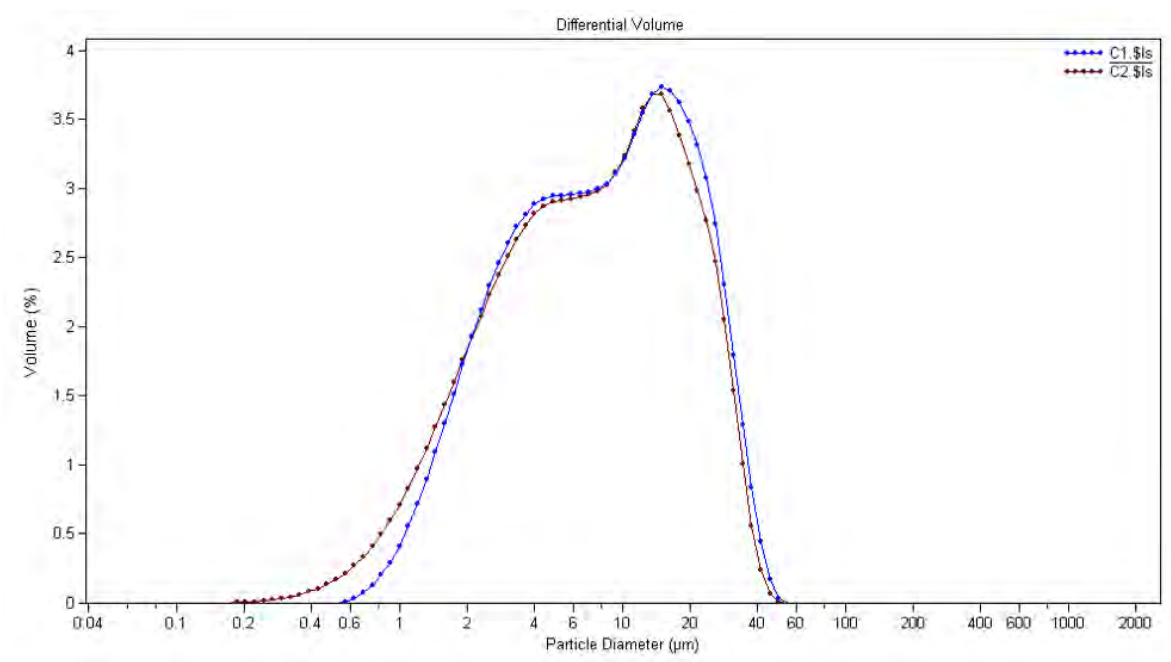

Figura 142 Diagrama diferencial de la granulometria de la serie C. 
RECERCA DE NOUS VIDRIATS, FORMULATS A PARTIR DE RESIDUS, I OBTINGUTS PER MITJÀ DE NOVES TECNOLOGIES DE PROCESSAT CERÀMIC

Taula 57 Mesures granulomètriques de la sèrie $C$.

\begin{tabular}{|l|l|}
\hline Mostra & $D_{99}(\mu \mathrm{m})$ \\
\hline $\mathrm{C} 1$ & 36 \\
\hline $\mathrm{C} 2$ & 33 \\
\hline
\end{tabular}

\subsubsection{Sèrie D.}

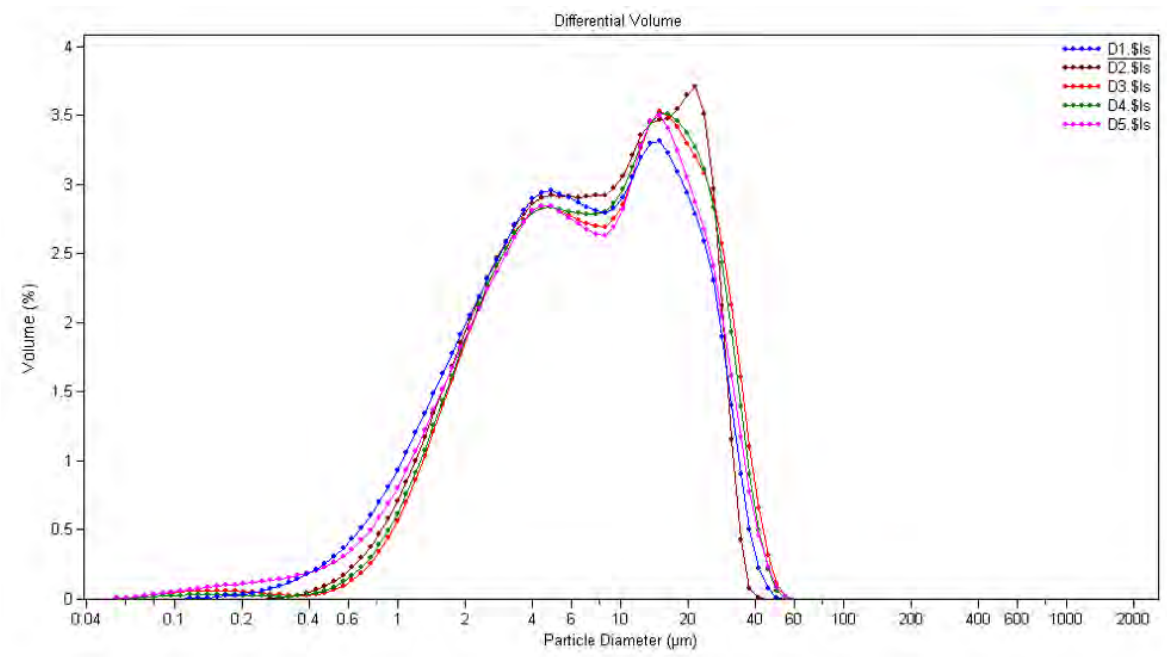

Figura 143 Diagrama diferencial de la granulometría de la sèrie D.

Taula 58 Mesures granulomètriques de la sèrie $D$.

\begin{tabular}{|l|l|}
\hline Mostra & $D_{99}(\mu \mathrm{m})$ \\
\hline D1 & 34 \\
\hline D2 & 32 \\
\hline D3 & 36 \\
\hline D4 & 36 \\
\hline D5 & 36 \\
\hline
\end{tabular}




\subsubsection{Sèrie E.}

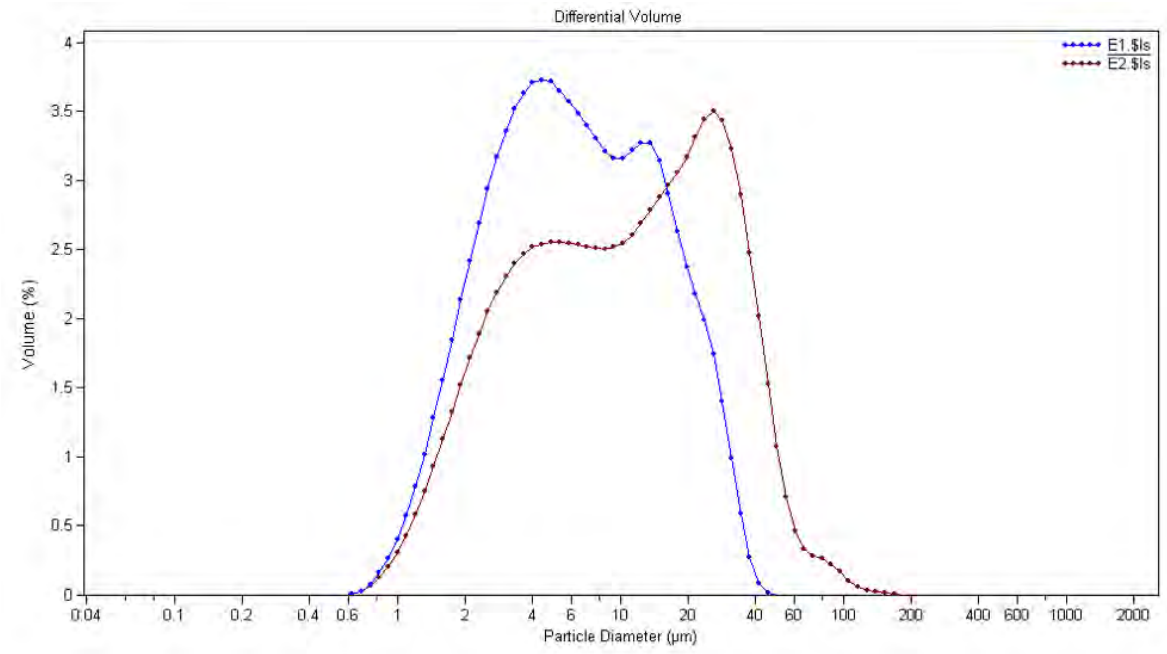

Figura 144 Diagrama diferencial de la granulometria de la sèrie $\mathrm{E}$.

Taula 59 Mesures de la granulometria de la sèrie $\mathrm{E}$.

\begin{tabular}{|l|l|}
\hline Mostra & $D_{99}(\mu \mathrm{m})$ \\
\hline E1 & 31 \\
\hline E2 & 58 \\
\hline
\end{tabular}

\subsubsection{Sèrie F.}

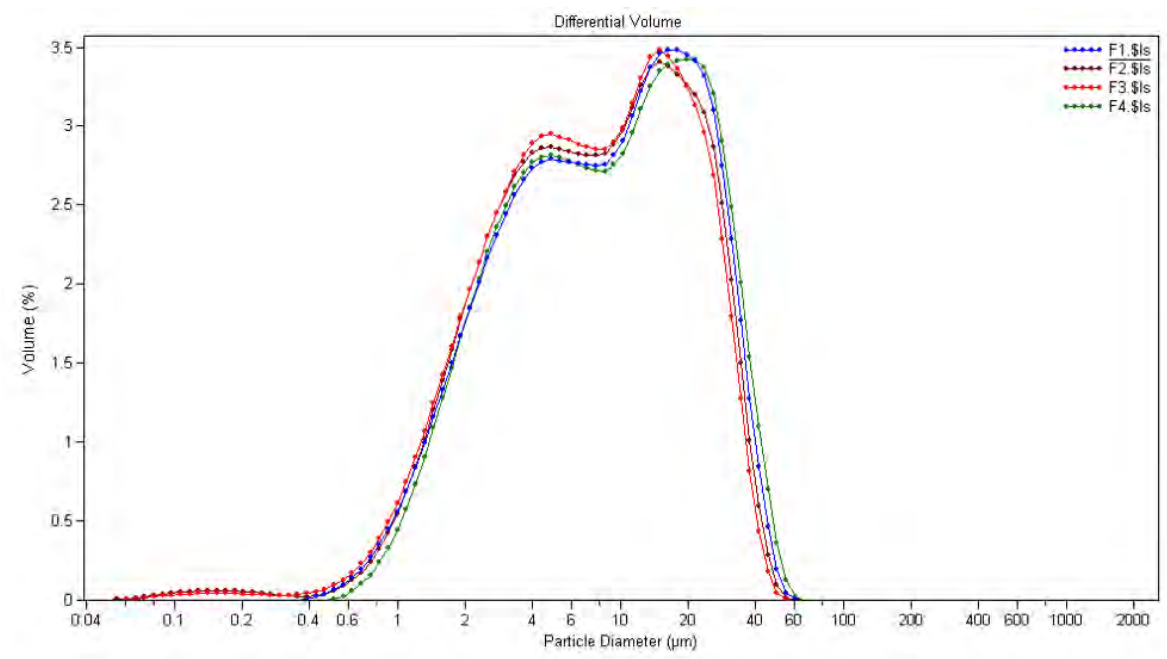

Figura 145 Diagrama diferencial de la granulometria de la sèrie $F$. 
RECERCA DE NOUS VIDRIATS, FORMULATS A PARTIR DE RESIDUS, I OBTINGUTS PER MITJÀ DE NOVES TECNOLOGIES DE PROCESSAT CERÀMIC

Taula 60 Mesures granulomètriques de la sèrie $F$.

\begin{tabular}{|l|l|}
\hline Mostra & $D_{99}(\mu \mathrm{m})$ \\
\hline F1 & 40 \\
\hline F2 & 37 \\
\hline F3 & 36 \\
\hline F4 & 44 \\
\hline
\end{tabular}

\subsubsection{Sèrie G.}

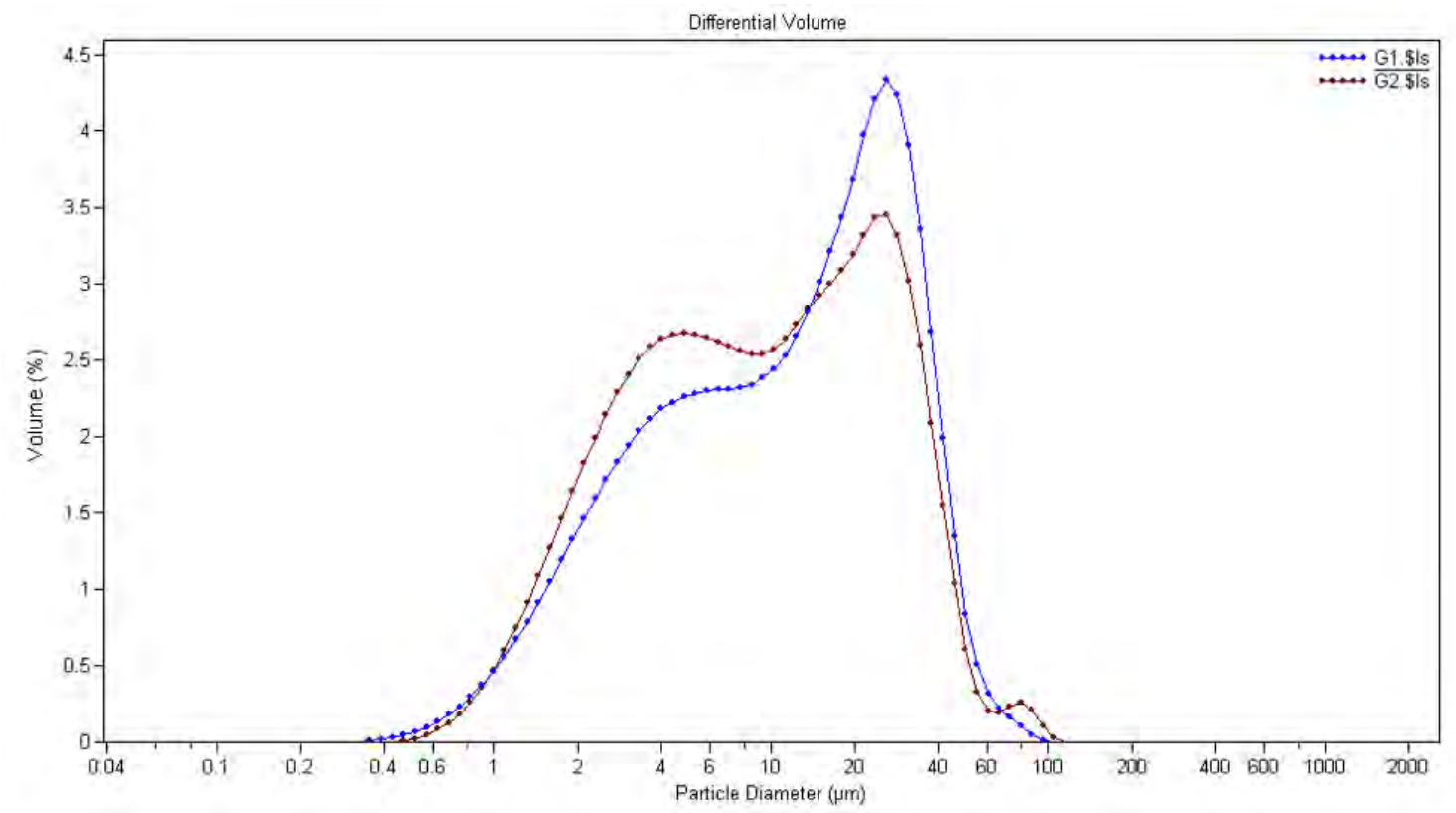

Figura 146 Diagrama diferencial en volum de la granulometria de la serie G.

Taula 61 Mesures granulomètriques de la sèrie G.

\begin{tabular}{|l|l|}
\hline Mostra & $D_{99}(\mu \mathrm{m})$ \\
\hline G1 & 55 \\
\hline G2 & 58 \\
\hline
\end{tabular}




\subsubsection{Sèrie H.}

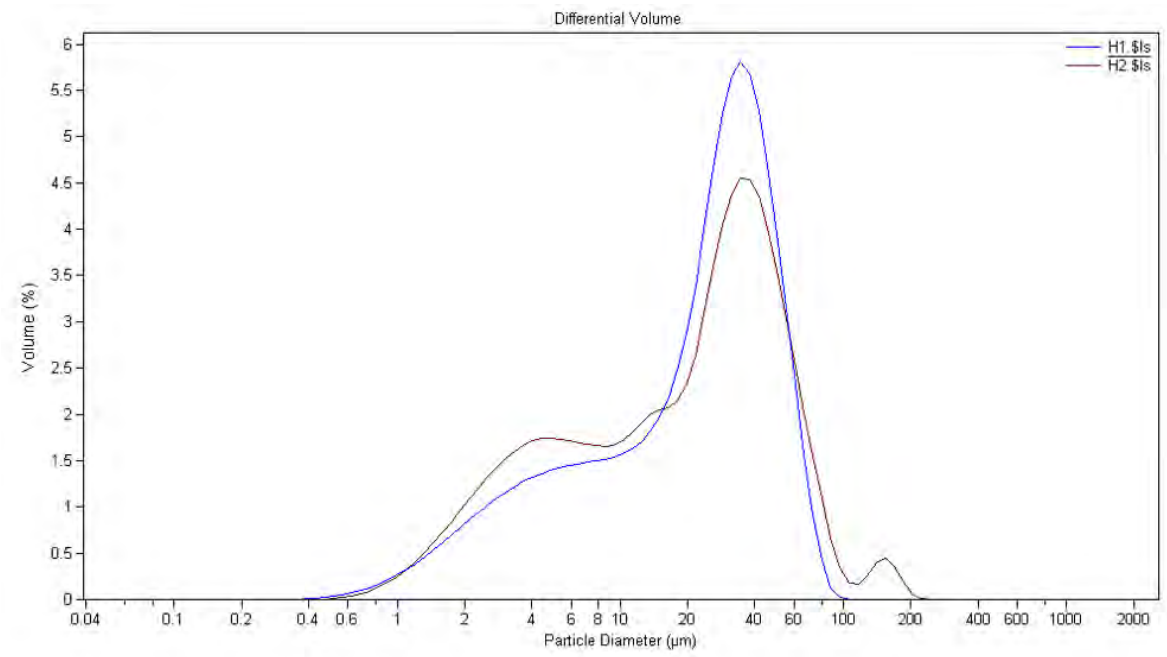

Figura 147 Diagrama diferencial de la granulometria de la serie H.

Es mostren els resultats a la Taula 62.

\begin{tabular}{|l|l|}
\hline Mostra & $D_{99}(\mu \mathrm{m})$ \\
\hline $\mathrm{H} 1$ & 63 \\
\hline $\mathrm{H} 2$ & 142 \\
\hline
\end{tabular}

Taula 62 Mesures granulomètriques de la sèrie $\mathrm{H}$.

\subsubsection{Sèrie I.}

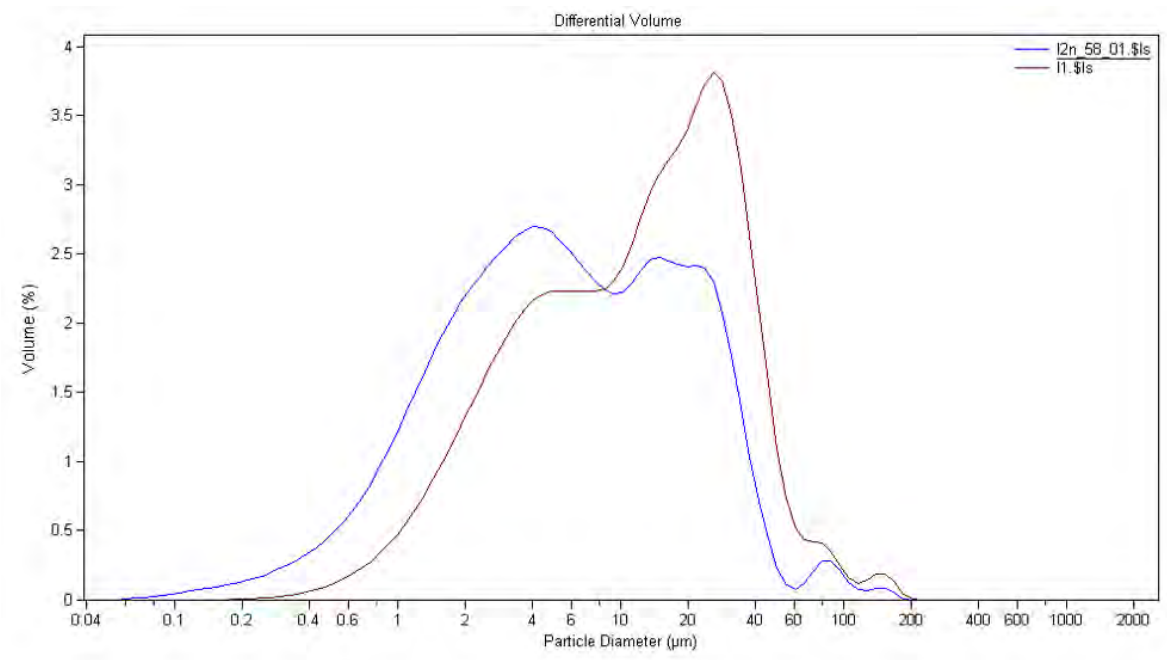

Figura 148 Diagrama diferencial de la granulometria de la sèrie I. 
RECERCA DE NOUS VIDRIATS, FORMULATS A PARTIR DE RESIDUS, I OBTINGUTS PER MITJÀ DE NOVES TECNOLOGIES DE PROCESSAT CERÀMIC

Taula 63 Mesures granulomètriques de la sèrie I.

\begin{tabular}{|l|l|}
\hline Mostra & $D_{99}(\mu \mathrm{m})$ \\
\hline$I 1$ & 100 \\
\hline 12 & 80 \\
\hline
\end{tabular}

\subsubsection{Sèrie J.}

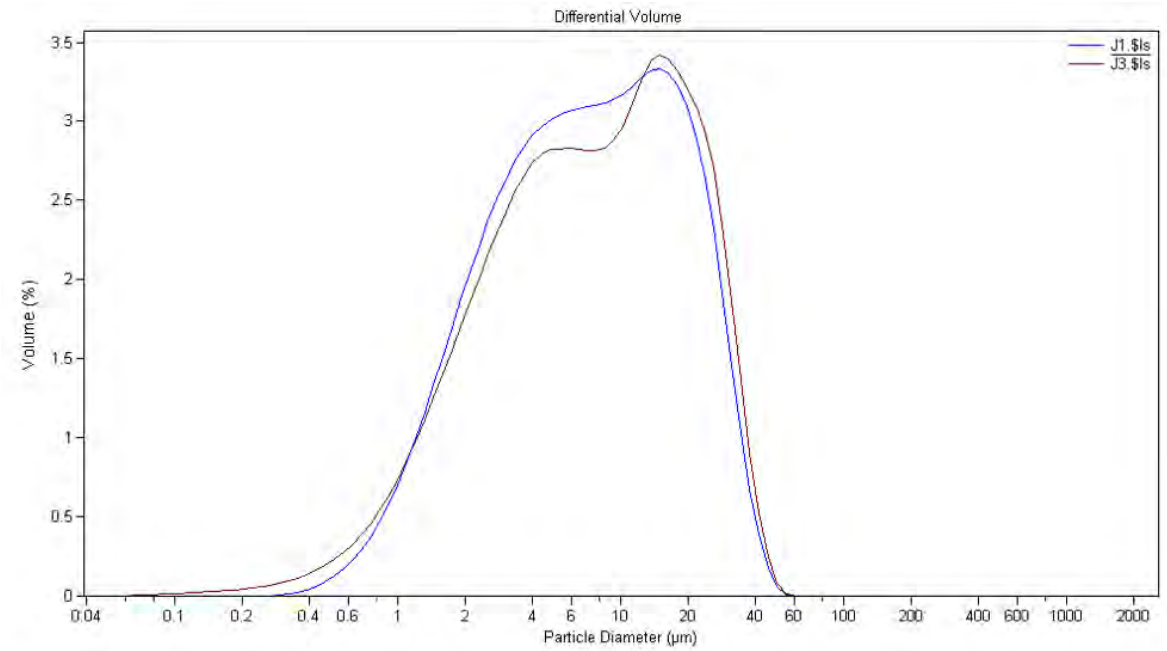

Taula 64 Mesures granulomètriques de la sèrie J.

\begin{tabular}{|l|l|}
\hline Mostra & $D_{99}(\mu \mathrm{m})$ \\
\hline $\mathrm{J} 1$ & 36 \\
\hline $\mathrm{J} 3$ & 36 \\
\hline
\end{tabular}


7.2 Anàlisis tèrmiques de les composicions no seleccionades.

Es mostren a continuació una anàlisi per sèrie:

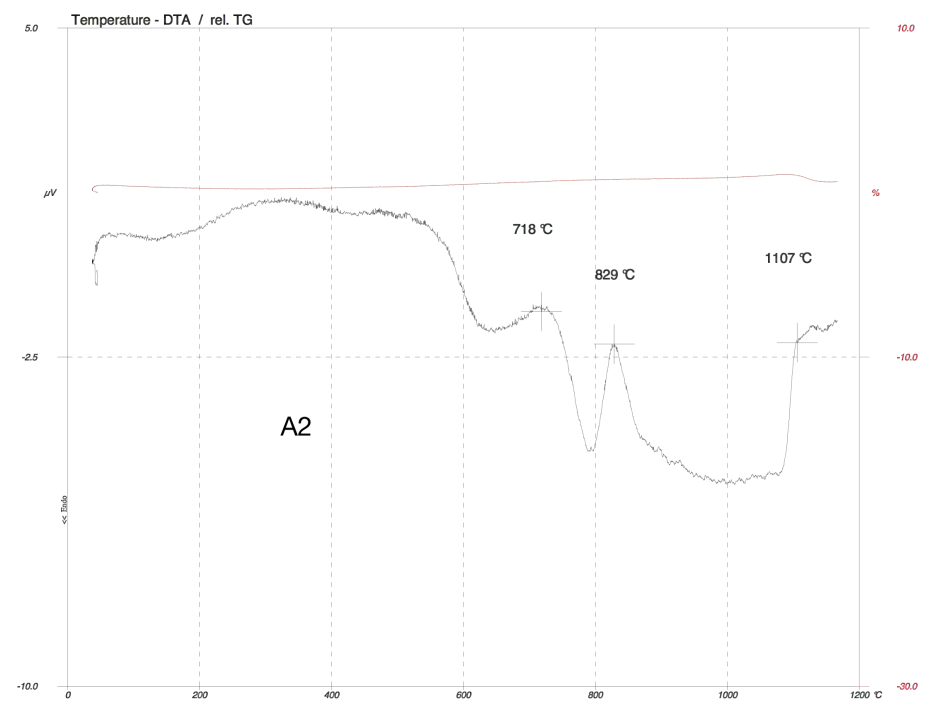

Figura 149 Anàlisis tèrmiques diferencial i gravimètric de la composició A2.

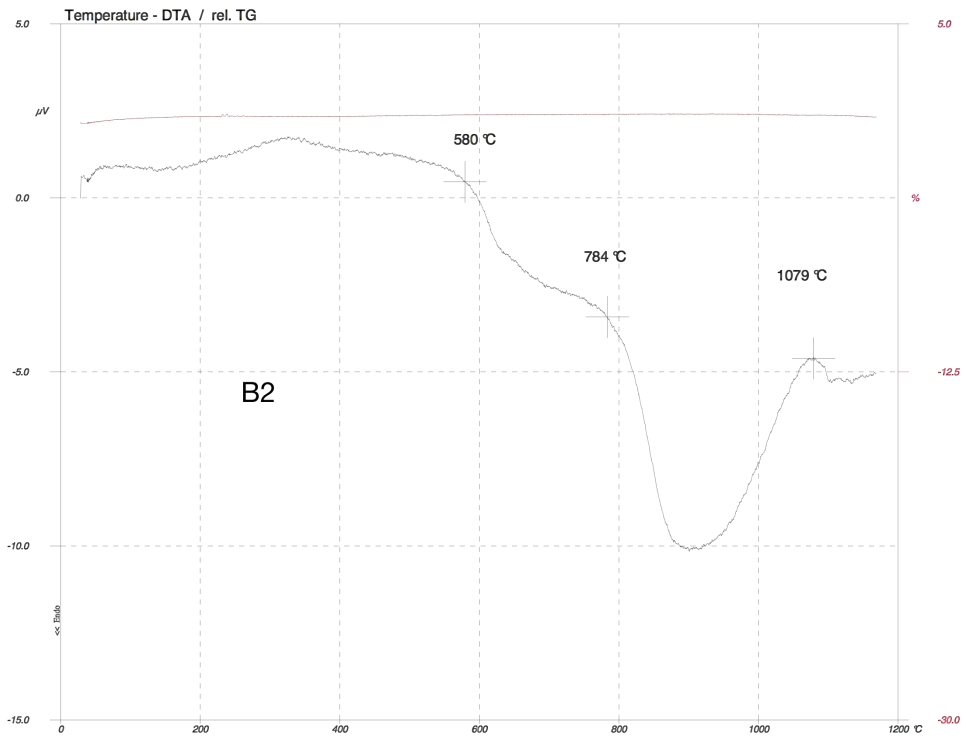

Figura 150 Anàlisis tèrmiques diferencial i gravimètric de la composició B2. 
RECERCA DE NOUS VIDRIATS, FORMULATS A PARTIR DE RESIDUS, I OBTINGUTS PER MITJÀ DE NOVES TECNOLOGIES DE PROCESSAT CERÀMIC

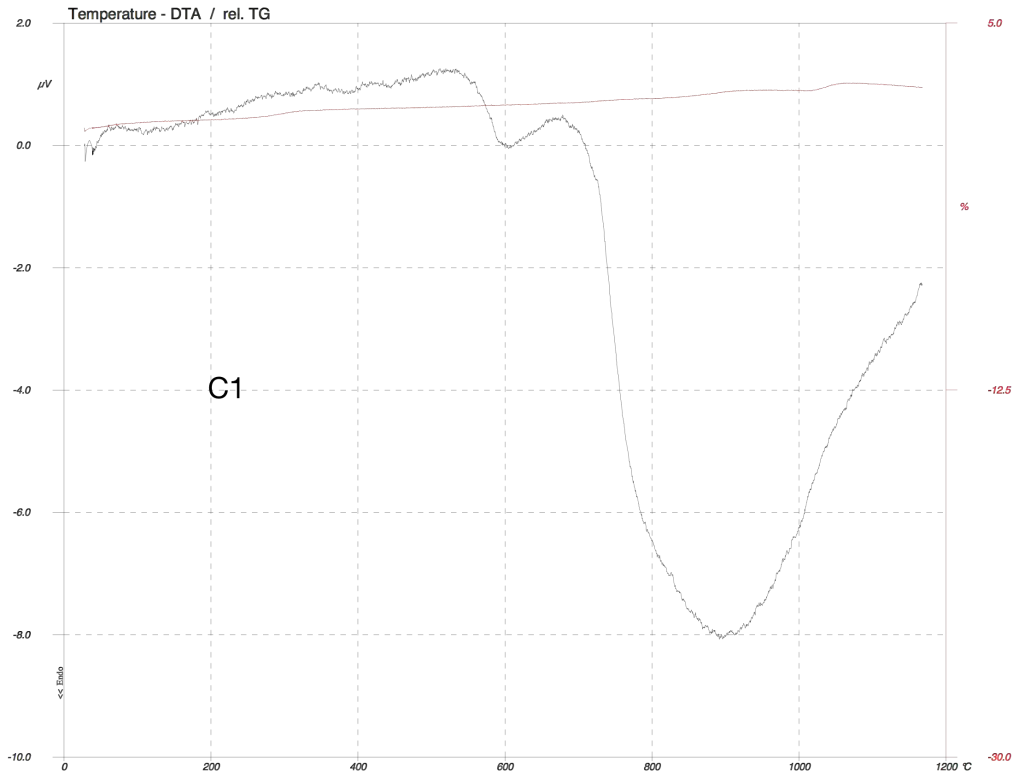

Figura 151 Anàlisis tèrmiques diferencial i gravimètric de la composició C1. 


\subsection{Difracció de Raigs $X$ de les frites.}

Se presenten per sèries, on es pot comprovar que són totes amorfes.

\subsubsection{Sèrie A.}

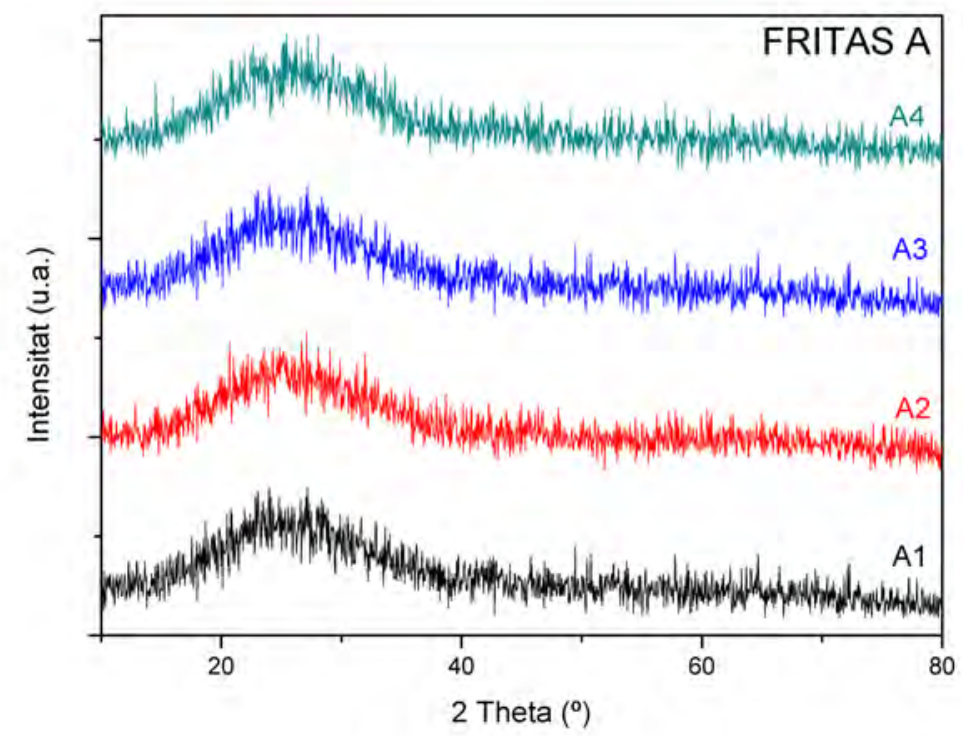

Figura 152 Difractometries de les frites de la sèrie $A$.

\subsubsection{Sèrie $B$.}

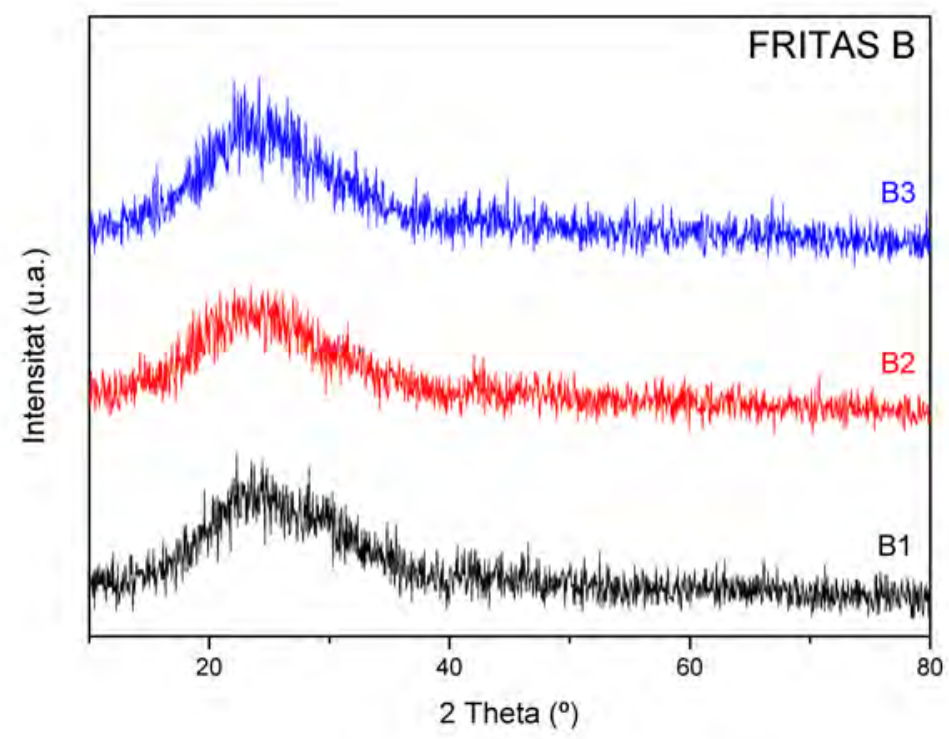

Figura 153 Difractometria de les frites de la sèrie $B$.

\subsubsection{Sèrie $\mathbf{C}$.}




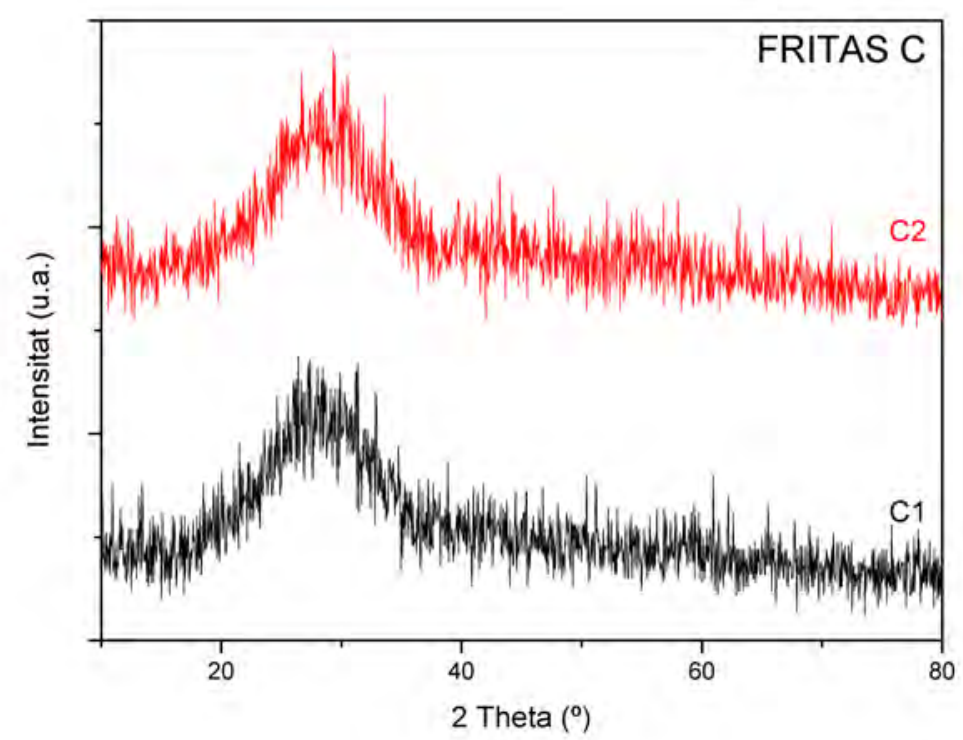

Figura 154 Difractograma de les frites de la sèrie $C$.

\subsubsection{Sèrie D.}

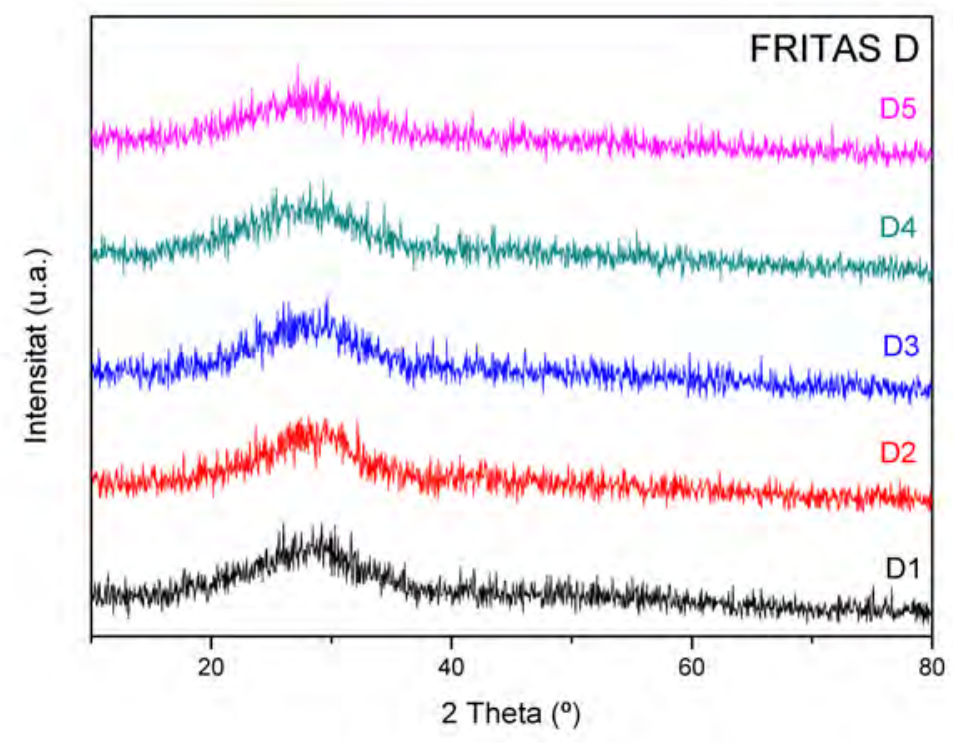

Figura 155 Difractometria de les frites de la sèrie $D$. 


\subsubsection{Sèrie E.}

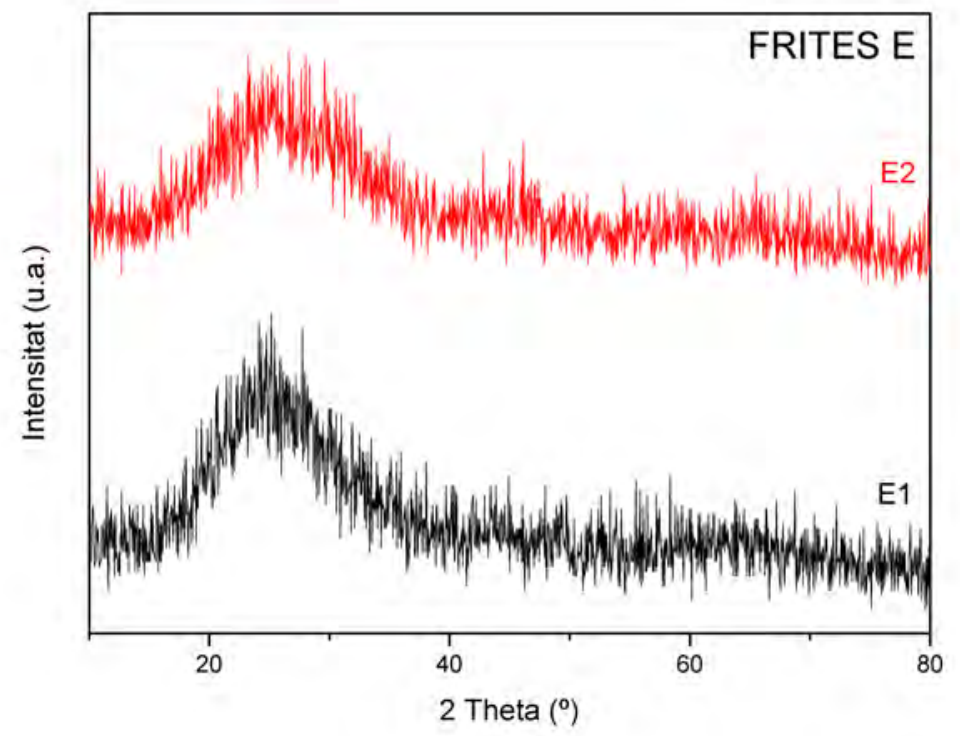

Figura 156 Difractograma de les frites de la sèrie E.

\subsubsection{Sèrie F.}

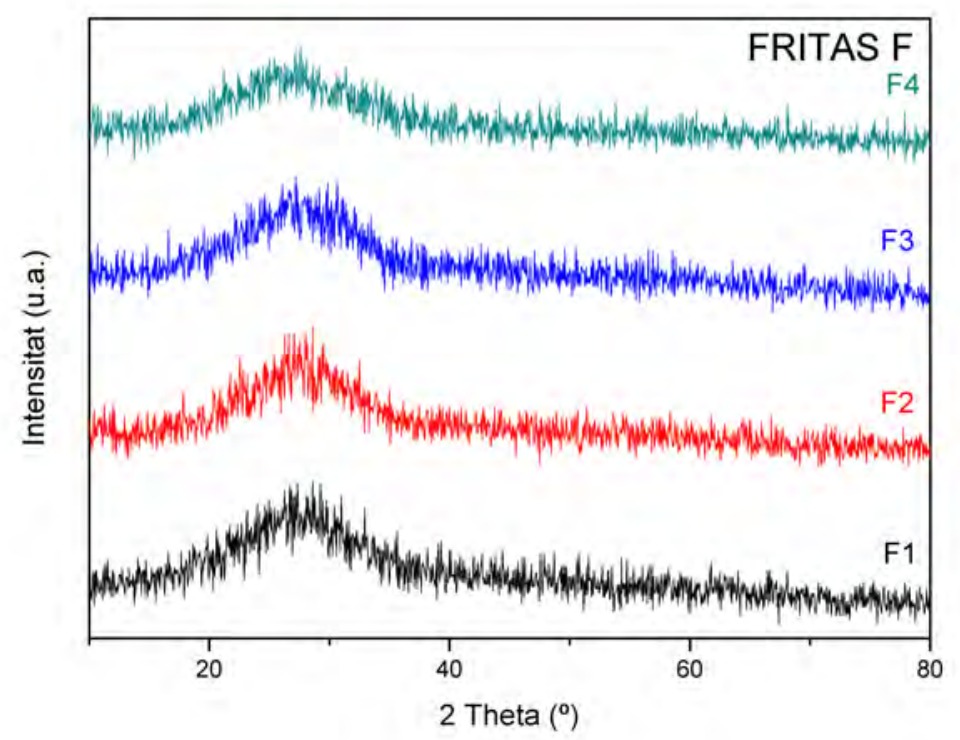

Figura 157 Difractogrames de la sèrie F. 


\subsubsection{Sèrie G.}

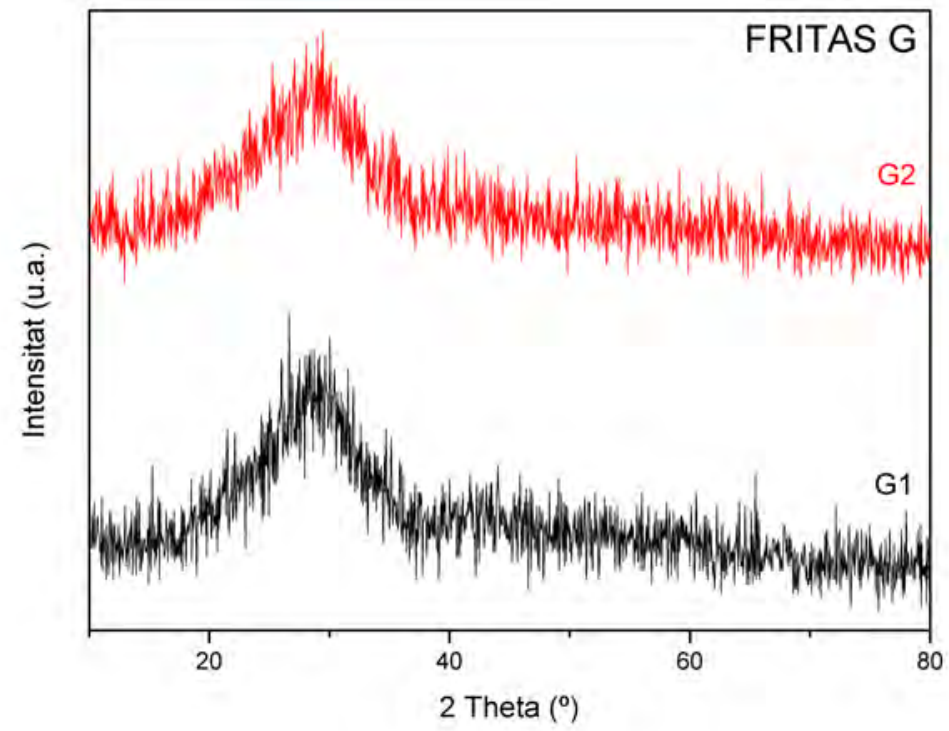

Figura 158 Difractograma de les frites de la sèrie G.

\subsubsection{Sèrie $\mathbf{H}$.}

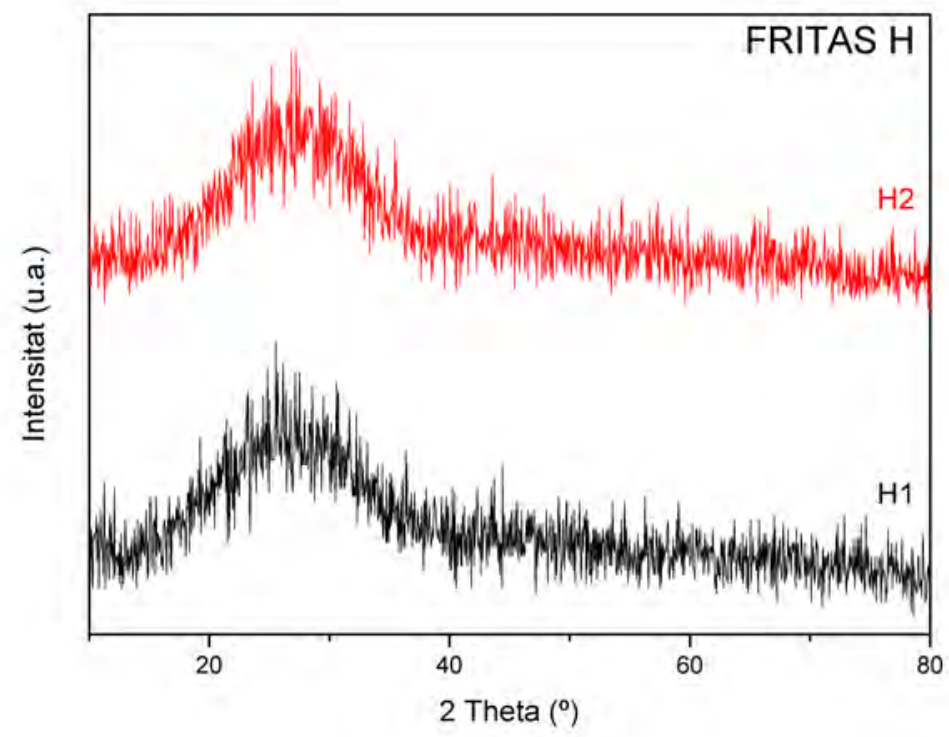

Figura 159 Difractograma de les frites de la sèrie $\mathrm{H}$. 


\subsubsection{Sèrie I.}

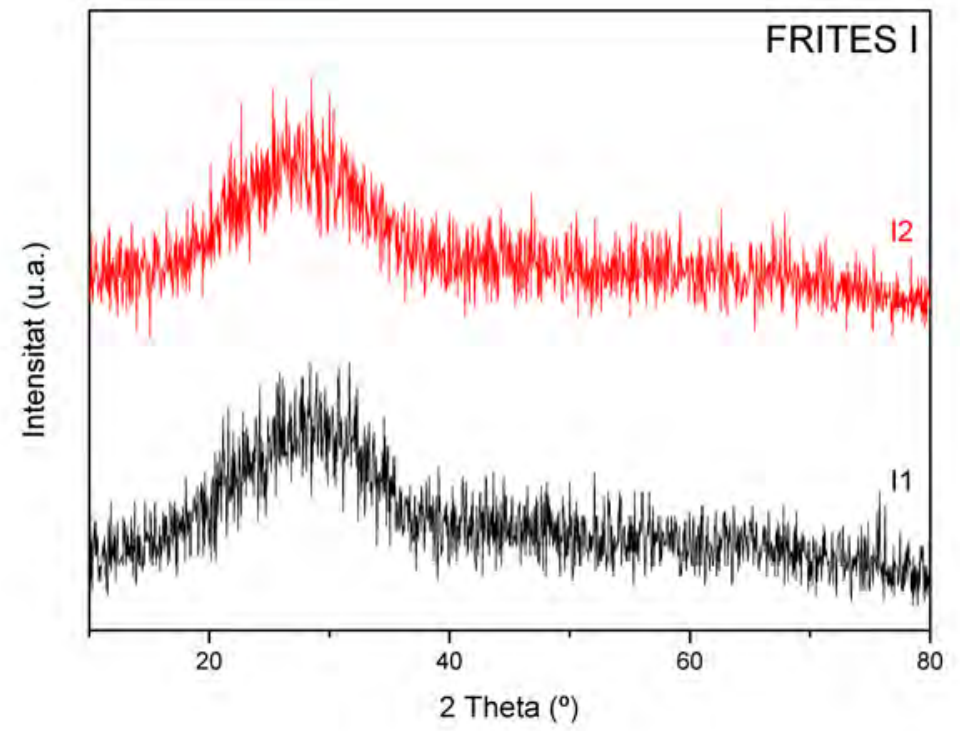

Figura 160 Difractograma de les frites de la sèrie I.

\subsubsection{Sèrie J.}

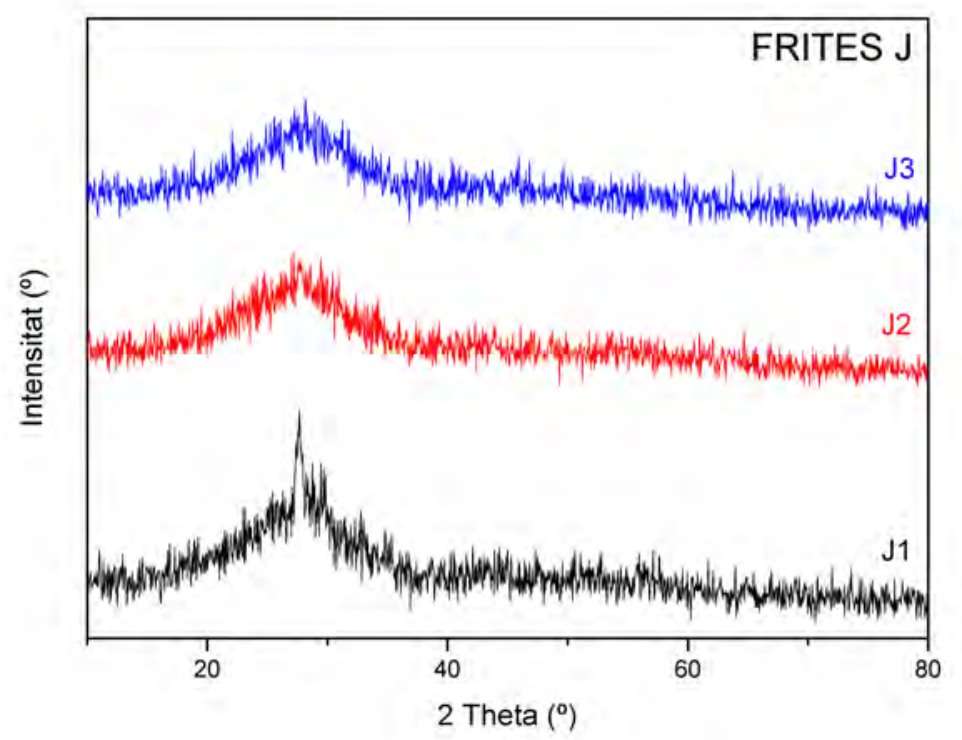

Figura 161 Difractogrames de les frites de la sèrie J. 


\subsection{Difracció de Raigs $\mathbf{X}$ de les composicions no seleccionades.}

Són amorfes al rang de manteniment a les temperatures assajats.

\subsubsection{Sèrie A.}

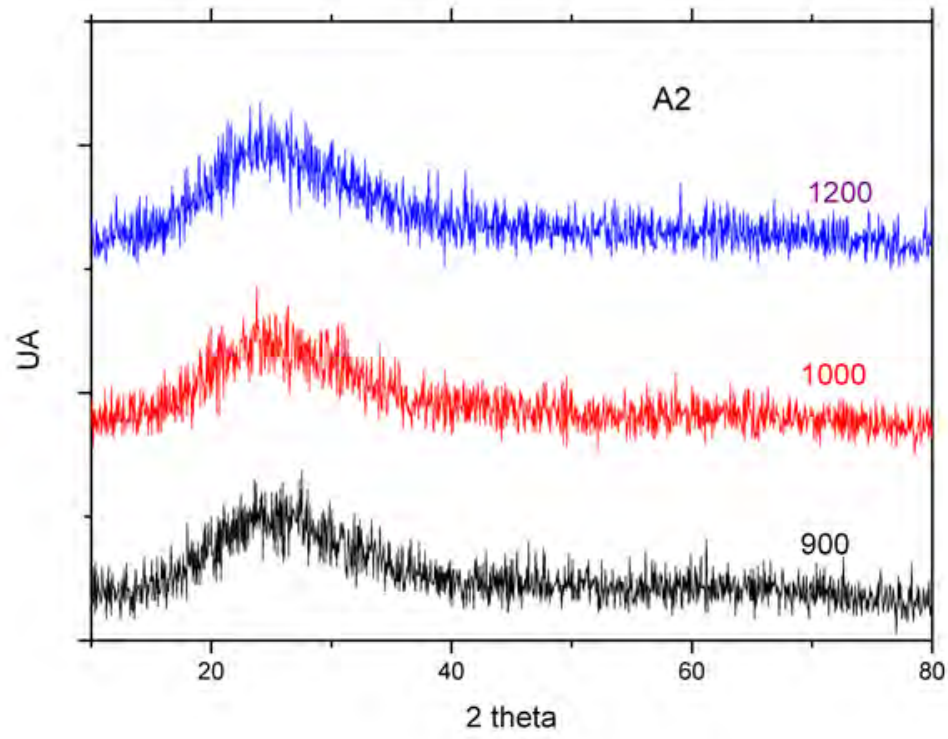

Figura 162 Difractograma de la composició A2 amb 1 hora de manteniment a 900, 1000 i 1200C.

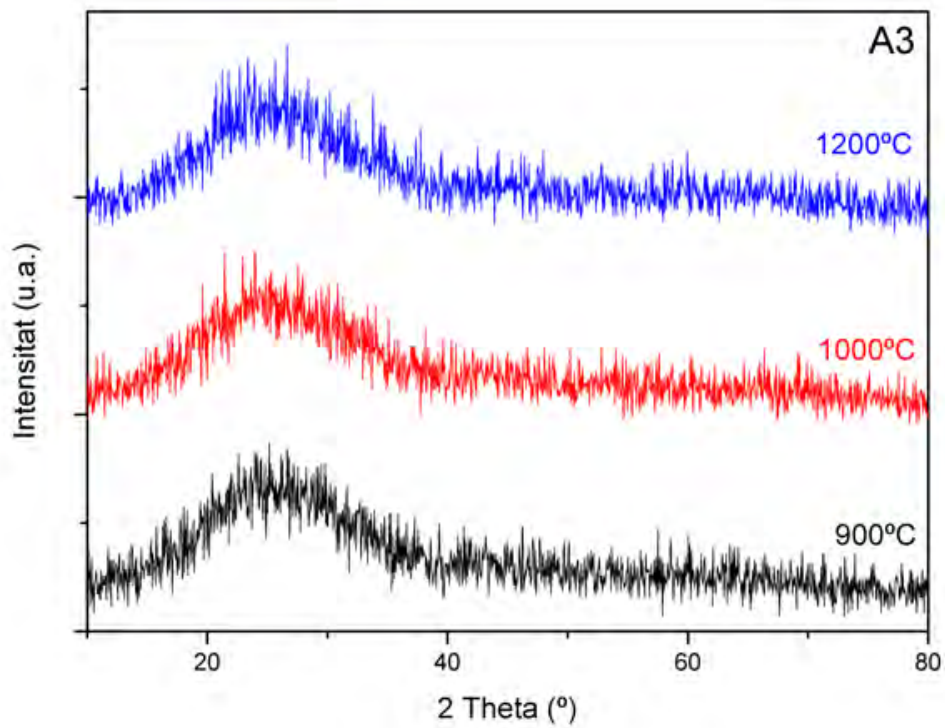

Figura 163 Difractograma de la composició A3 amb 1 hora de manteniment a 900, 1000 i 1200C. 


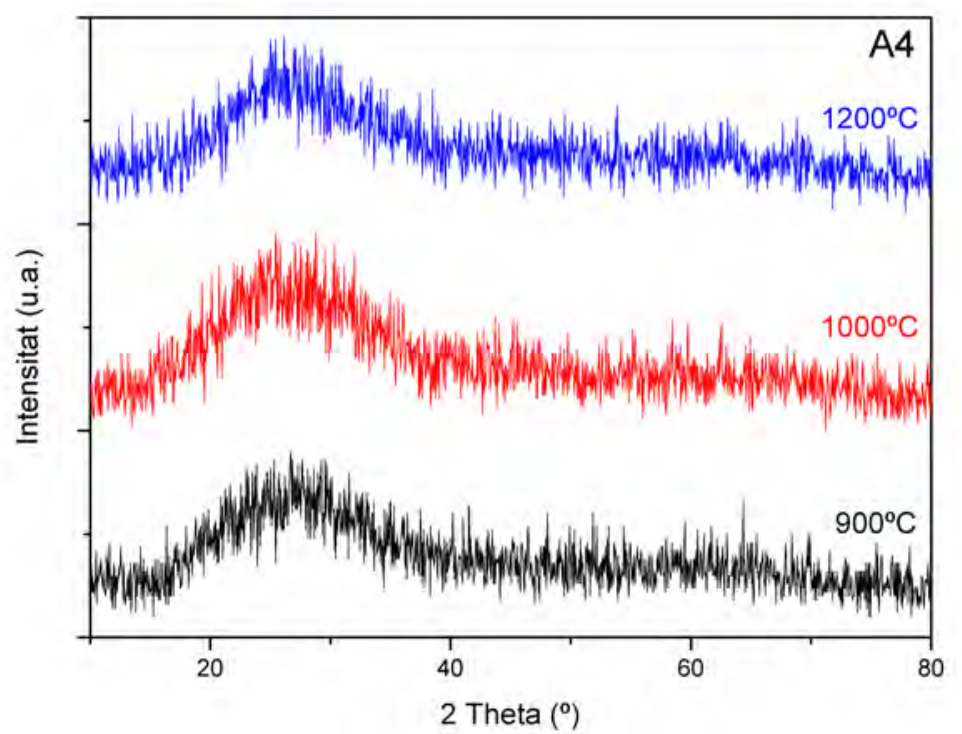

Figura 164 Difractograma de la composició A4 amb una hora de manteniment a 900, 1000 i 1200C.

\subsubsection{Sèrie B.}

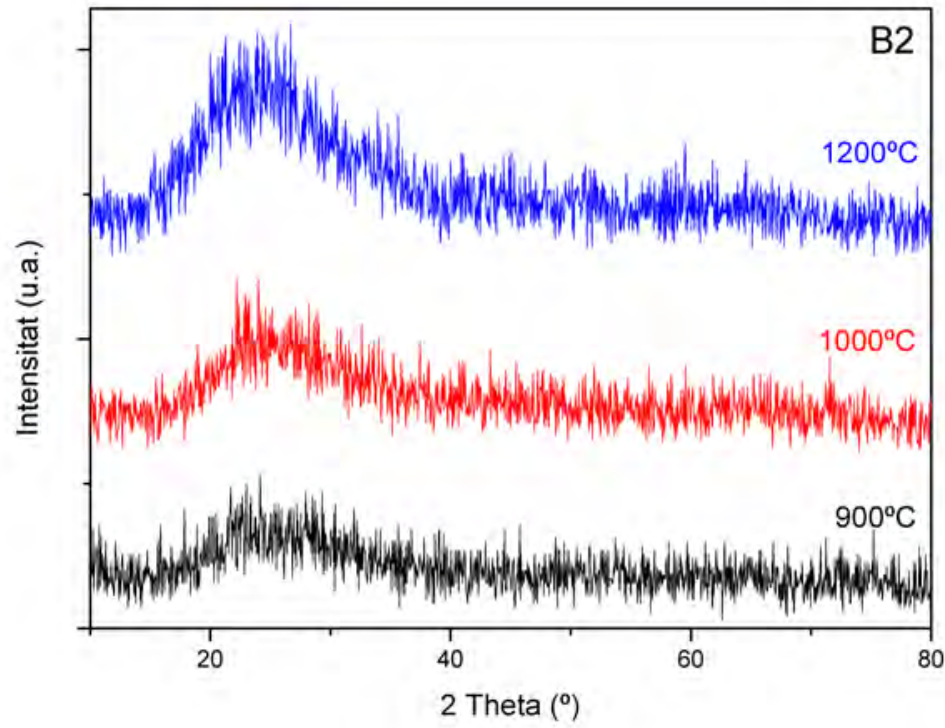

Figura 165 Difractograma de la composició B2 amb una hora de manteniment a 900, 1000 i 1200ㄷ. 


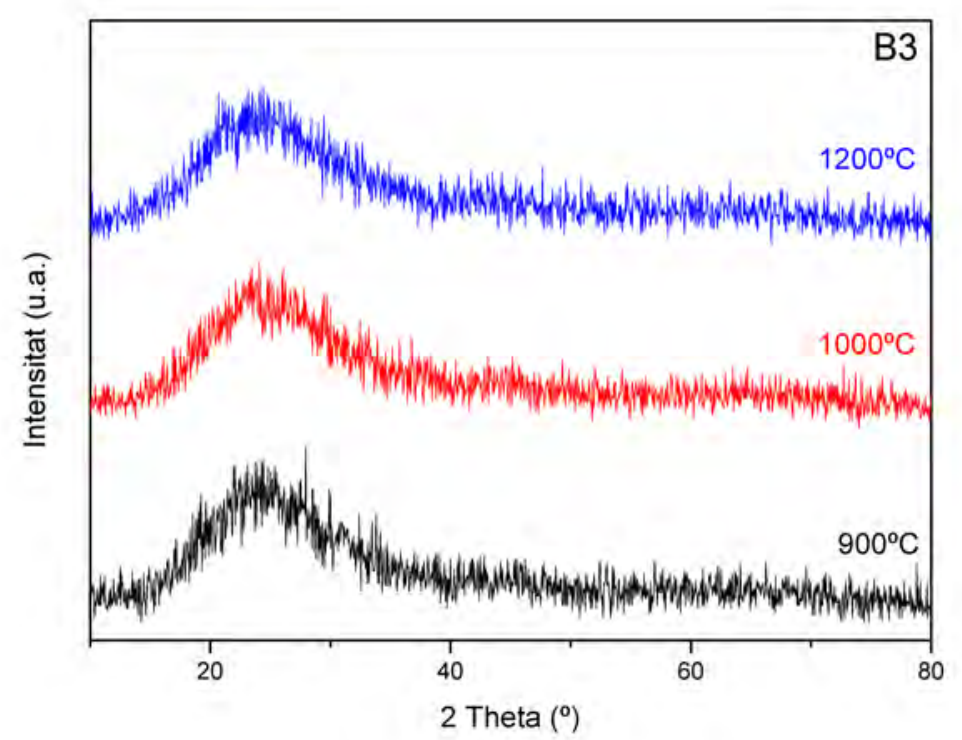

Figura 166 Difractograma de la composició B3 amb una hora de manteniment a 900, 1000 i 1200 C.

\subsubsection{Sèrie C.}

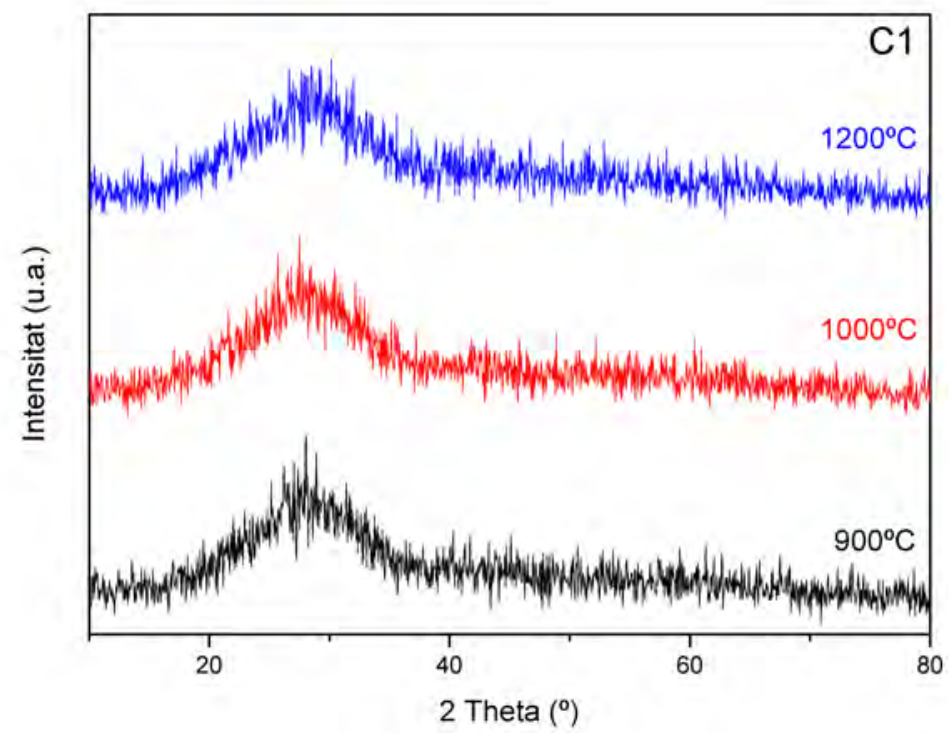

Figura 167 Difractograma de la composició C1 amb una hora de manteniment a 900, 1000 i 1200C. 


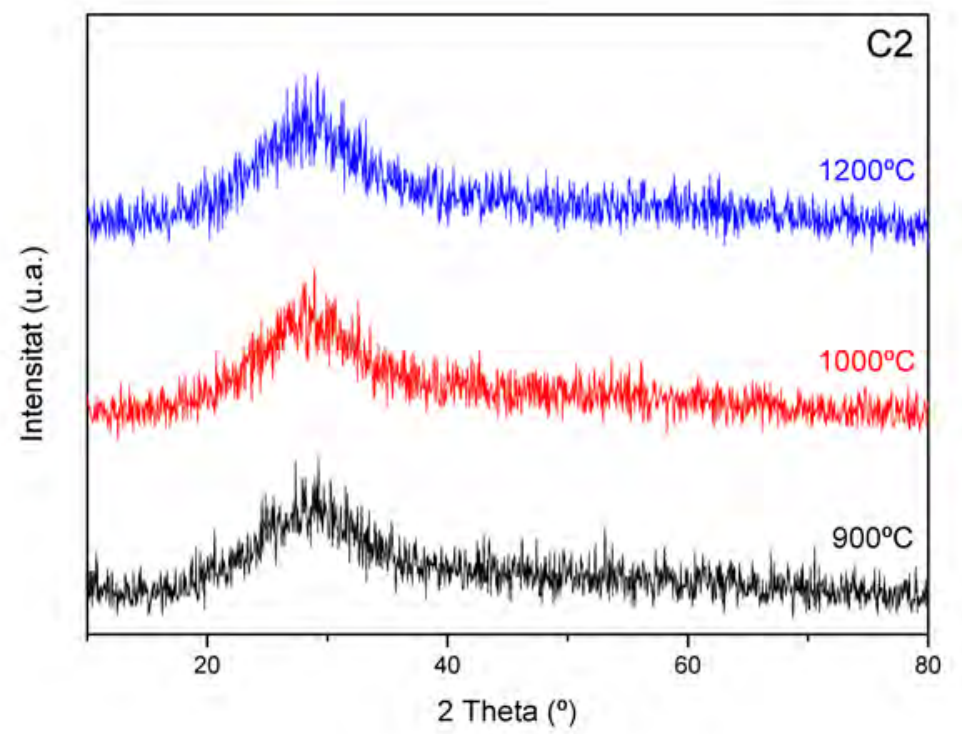

Figura 168 Difractograma de la composició C2 amb una hora de manteniment a 900, 1000 i 1200C.

\subsubsection{Sèrie D.}

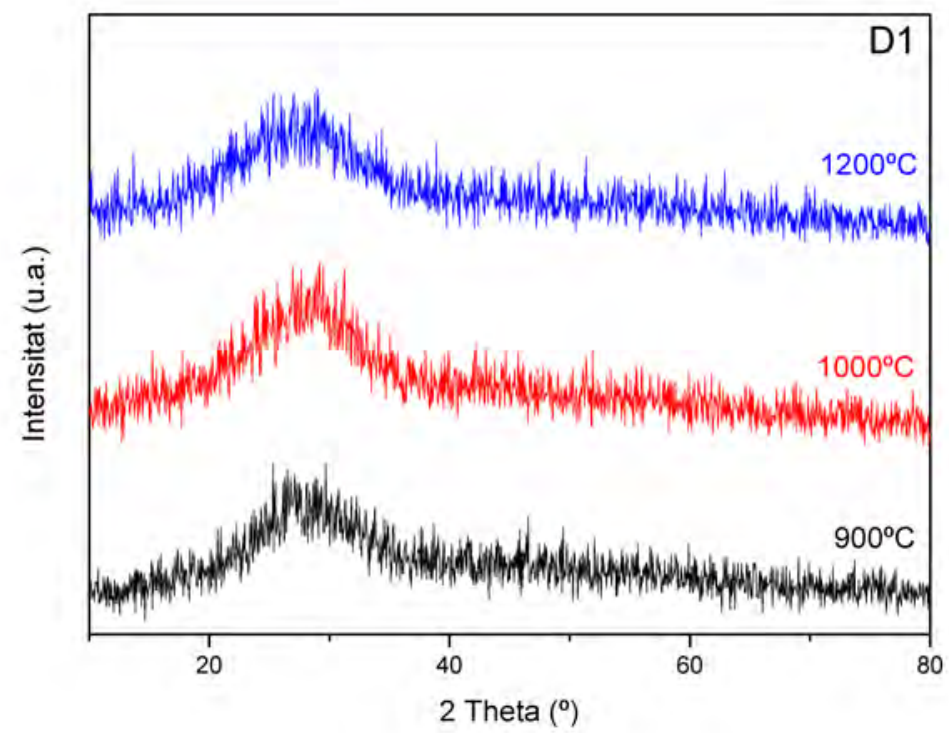

Figura 169 Difractograma de la composició D1 amb una hora de manteniment a 900, 1000 i 1200C. 


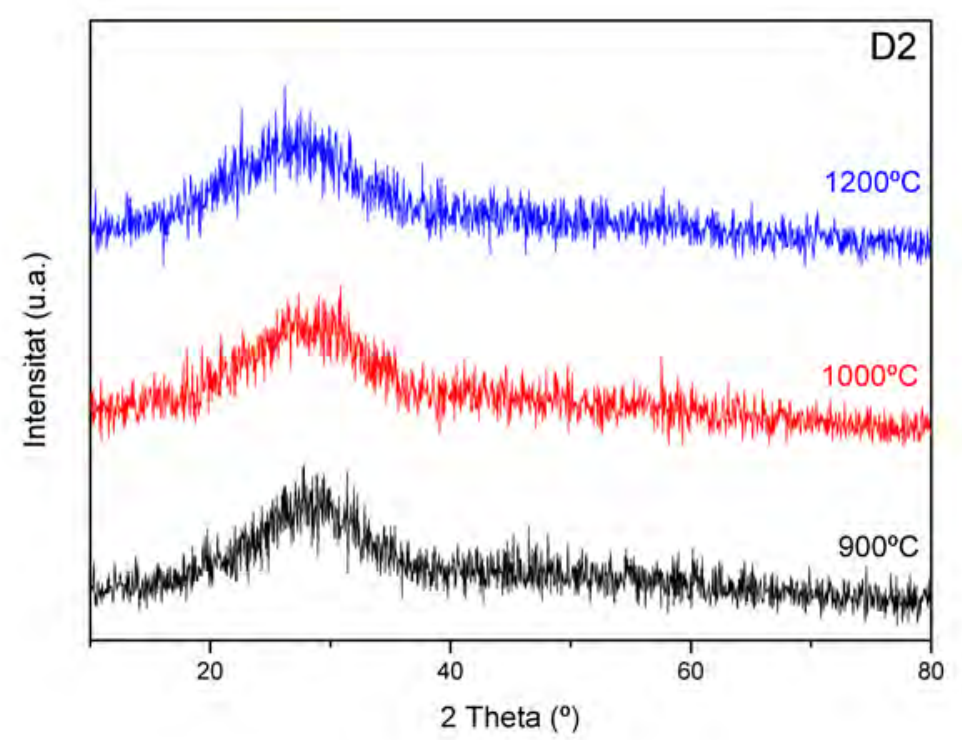

Figura 170 Difractograma de la composició D2 amb una hora de manteniment a 900, 1000 i 1200 C.

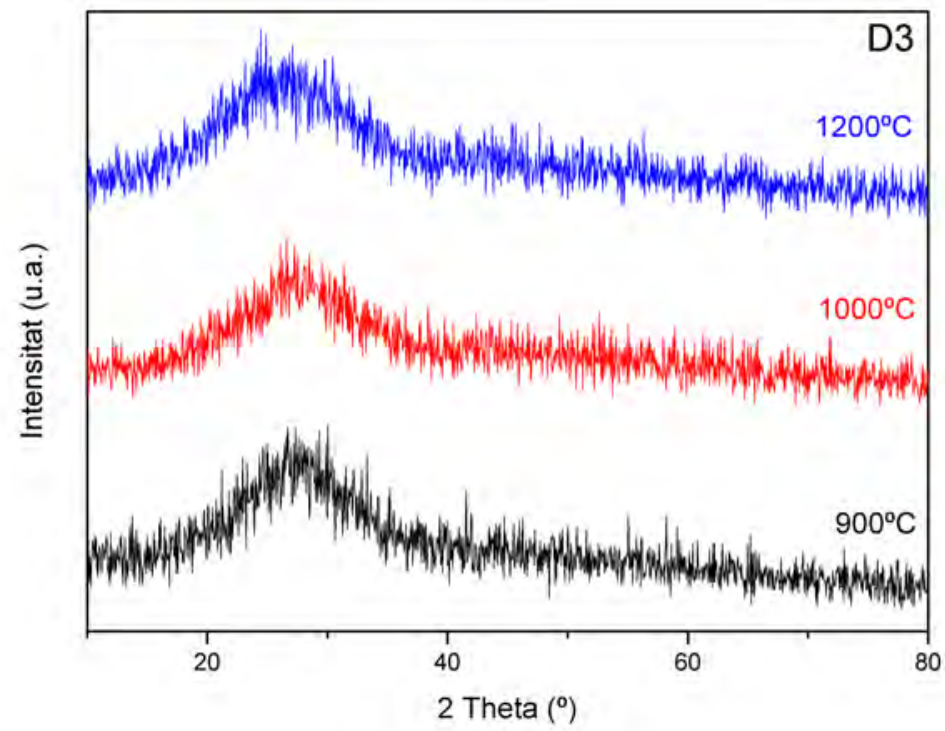

Figura 171 Difractograma de la composició D3 amb una hora de manteniment a 900, 1000 i 1200 ㄷ. 


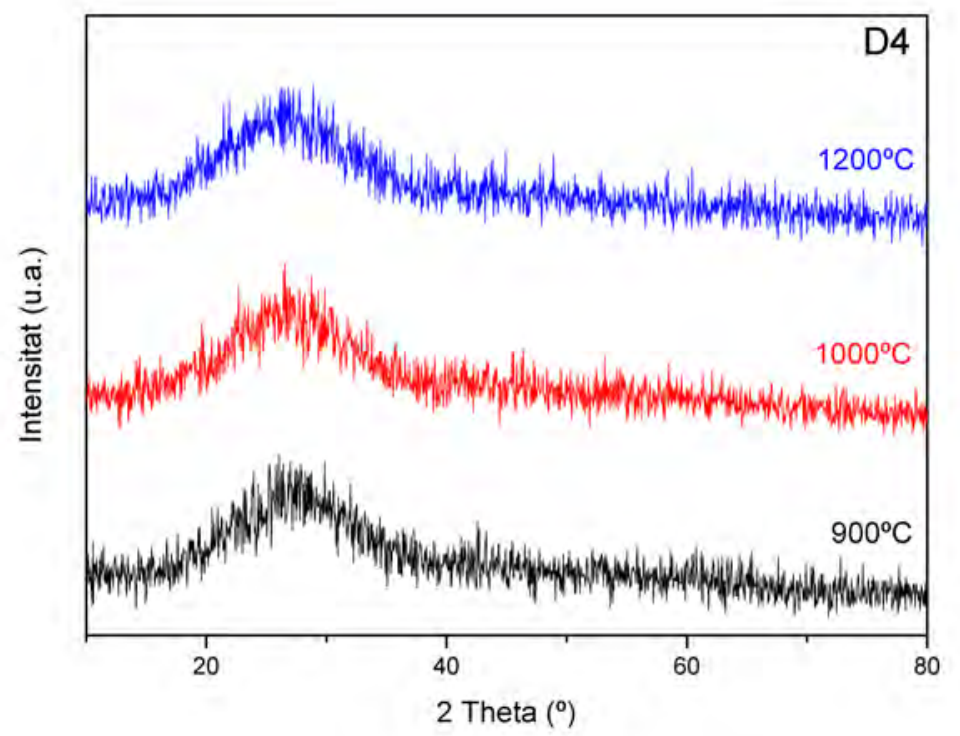

Figura 172 Difractograma de la composició D4 amb una hora de manteniment a 900, 1000 i 1200C.

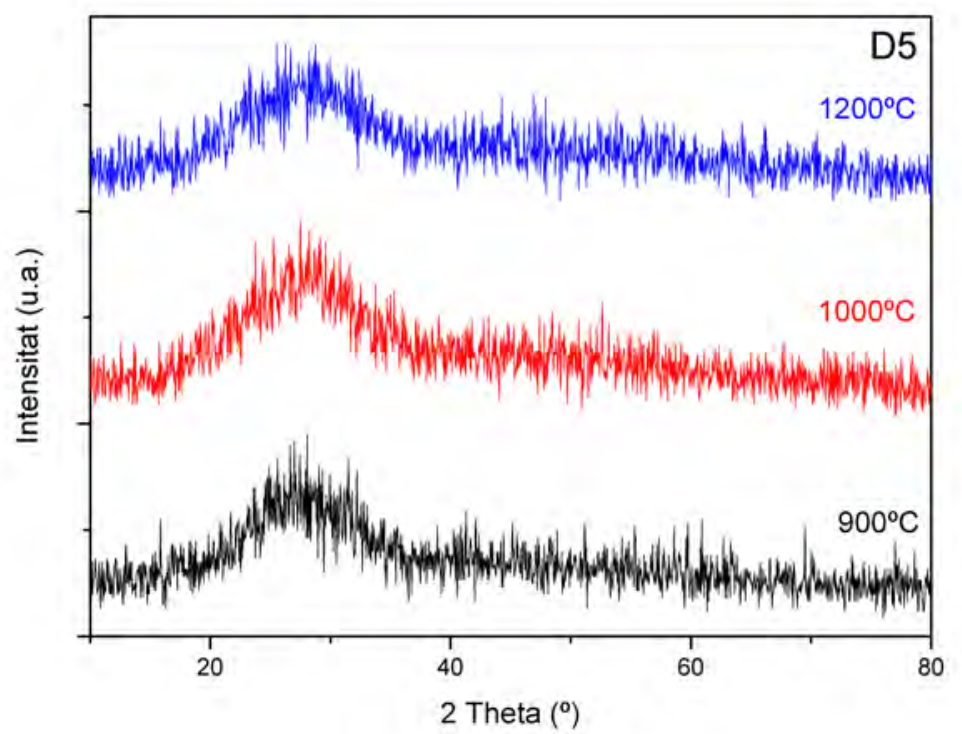

Figura 173 Difractograma de la composició D5 amb una hora de manteniment a 900, 1000 i 1200C. 


\subsubsection{Sèrie E.}

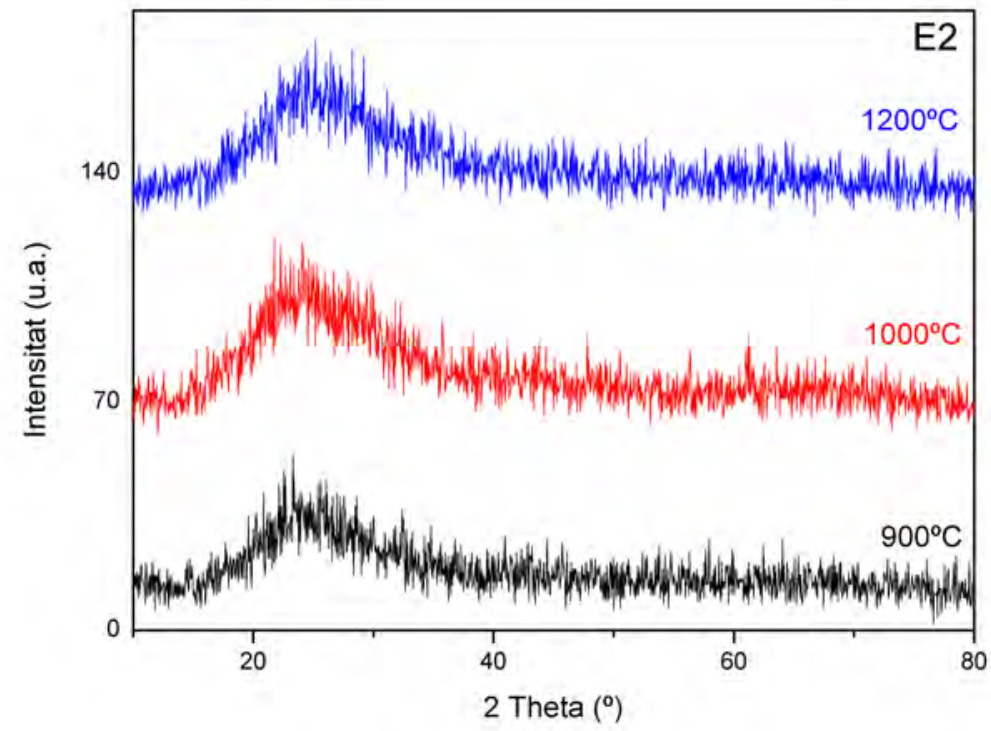

Figura 174 Difractograma de la composició E2 amb una hora de manteniment a 900, 1000 i 1200 ㄷ.

\subsubsection{Sèrie F.}

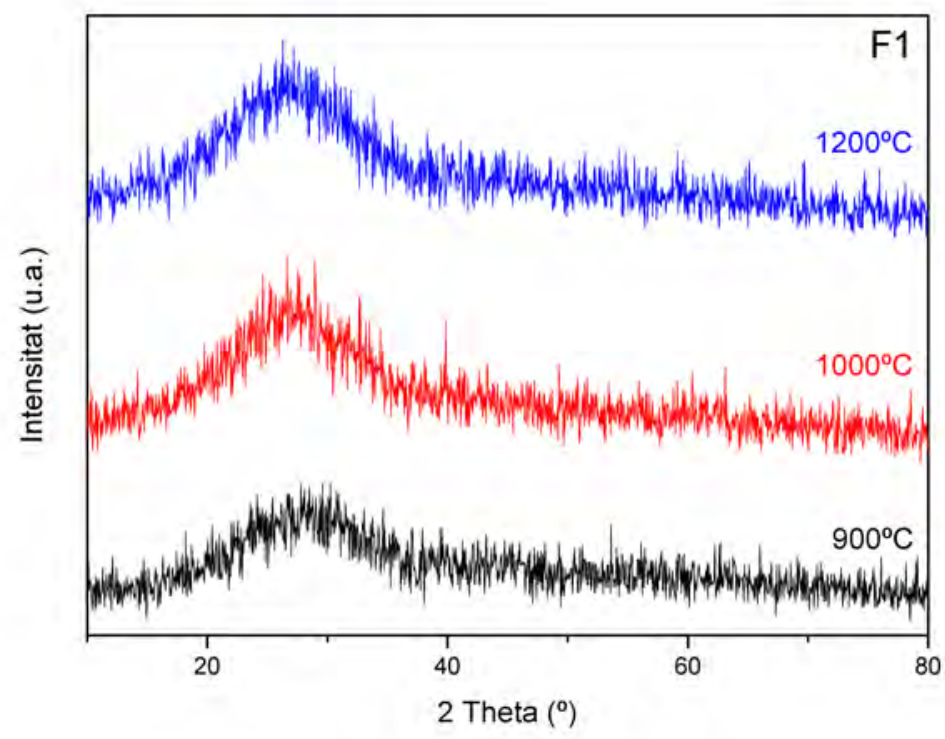

Figura 175 Diractograma de la composició F1 amb una hora de manteniment a 900, 1000 i 1200 ㄷ. 


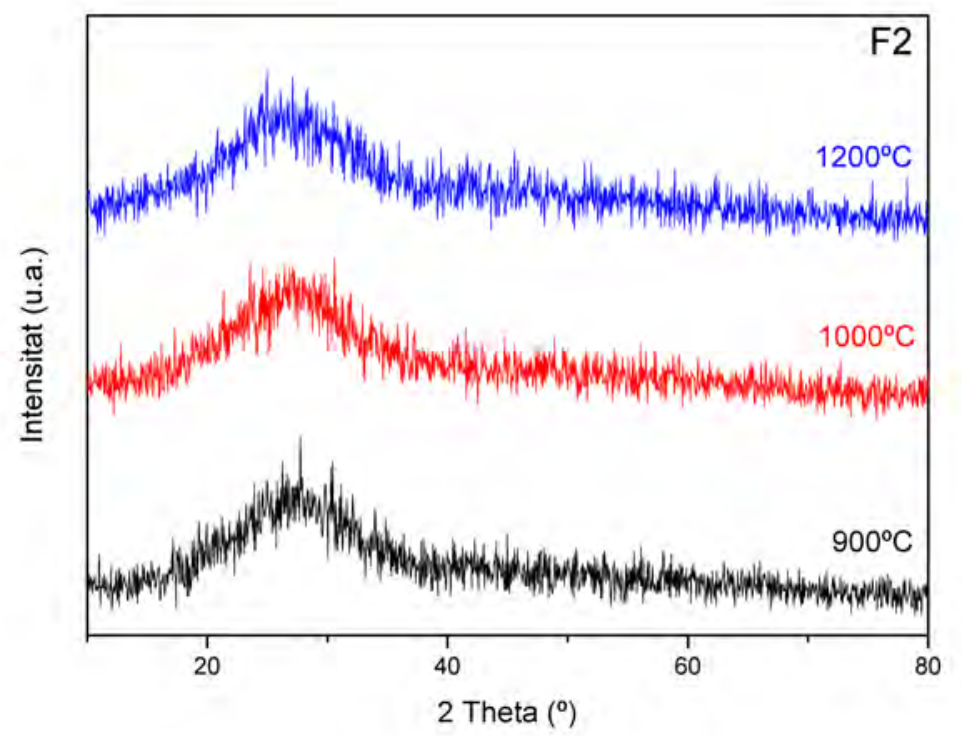

Figura 176 Difractograma de la composició F2 amb una hora de manteniment a 900, 1000 i 1200C.

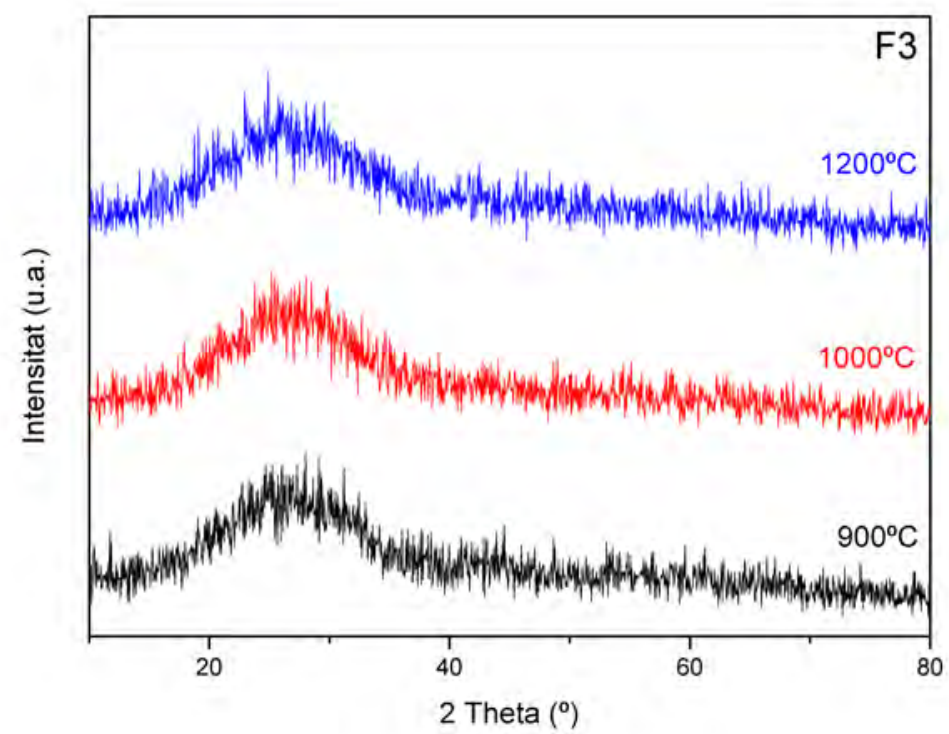

Figura 177 Difractograma de la composició F3 amb una hora de manteniment a 900, 1000 i 1200C. 


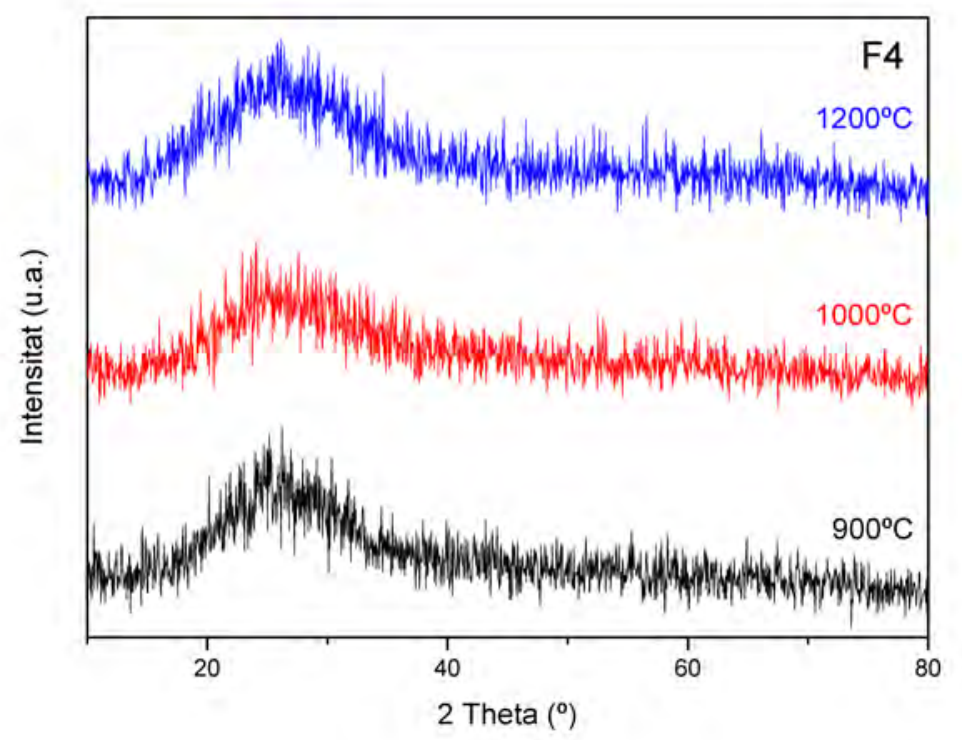

Figura 178 Difractograma de la composició F4 amb una hora de manteniment a 900, 1000 i 1200 C.

\subsubsection{Sèrie G.}

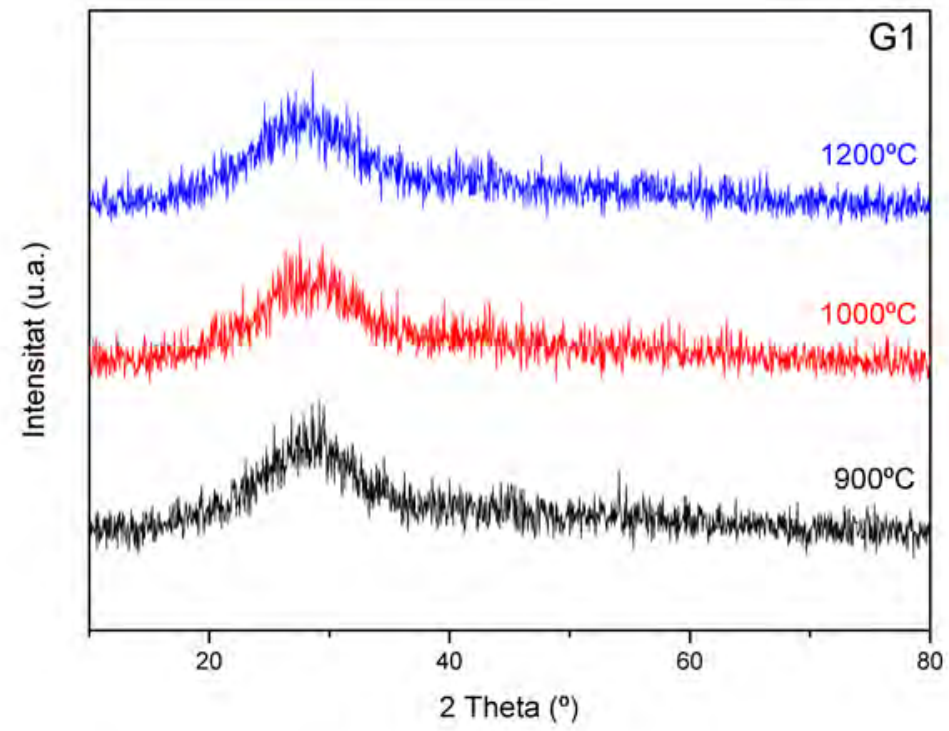

Figura 179 Difractograma de la composició G1 amb una hora de manteniment a 900, 1000 i 1200 C. 


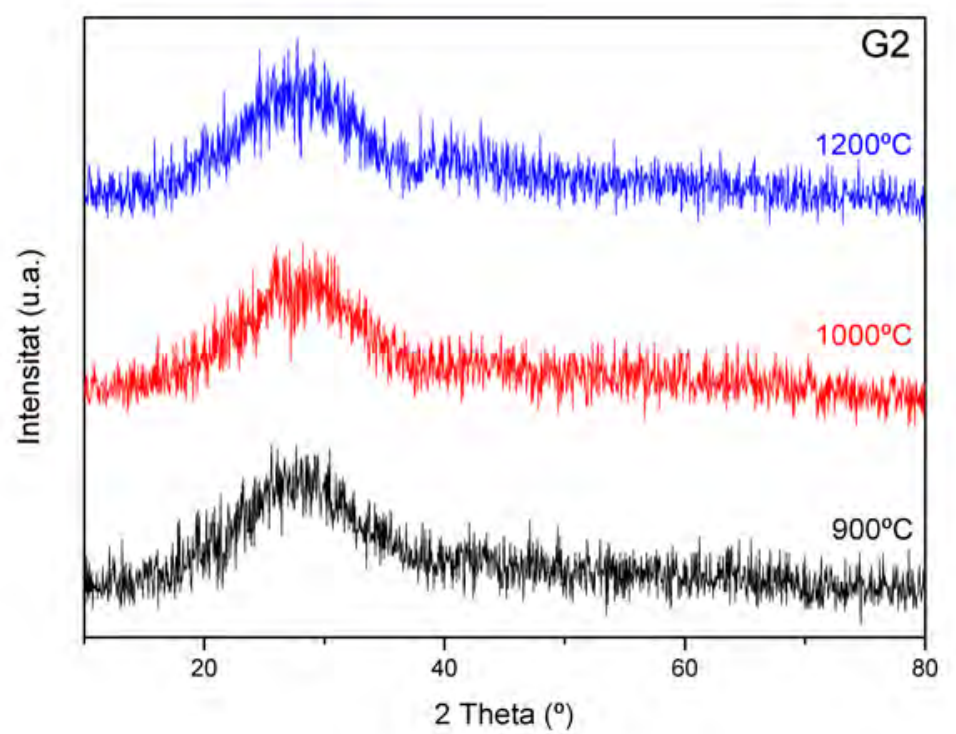

Figura 180 Difractograma de la composició G2 amb una hora de manteniment a 900, 1000 i 1200C.

\subsubsection{Sèrie $\mathrm{H}$.}

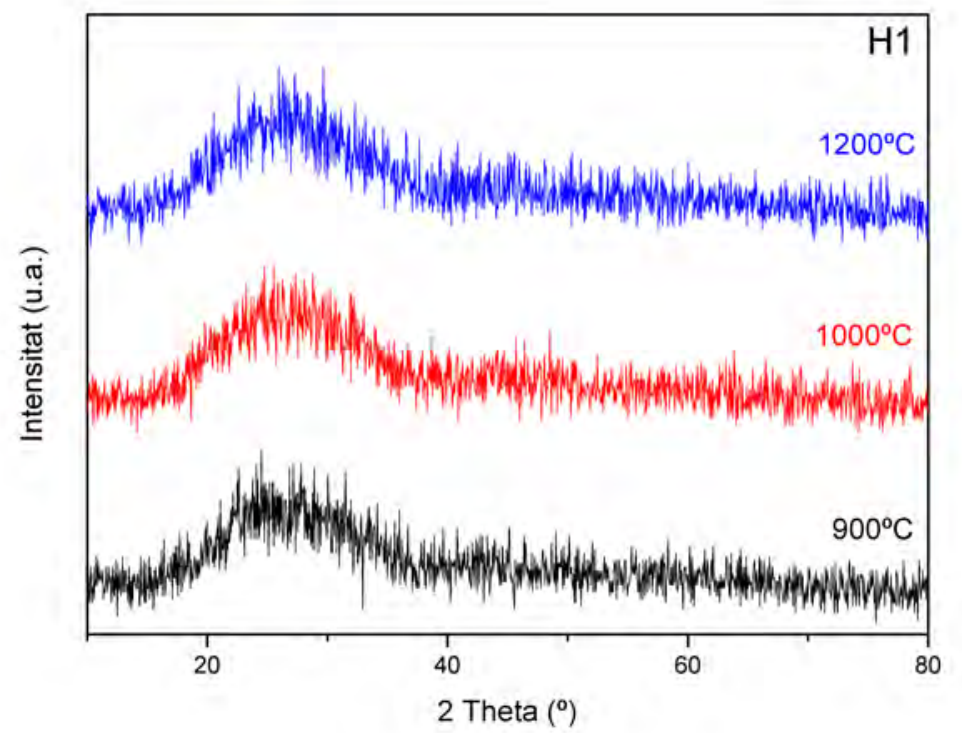

Figura 181 Difractograma de la composició H1 amb una hora de manteniment a 900, 1000 i 1200C. 


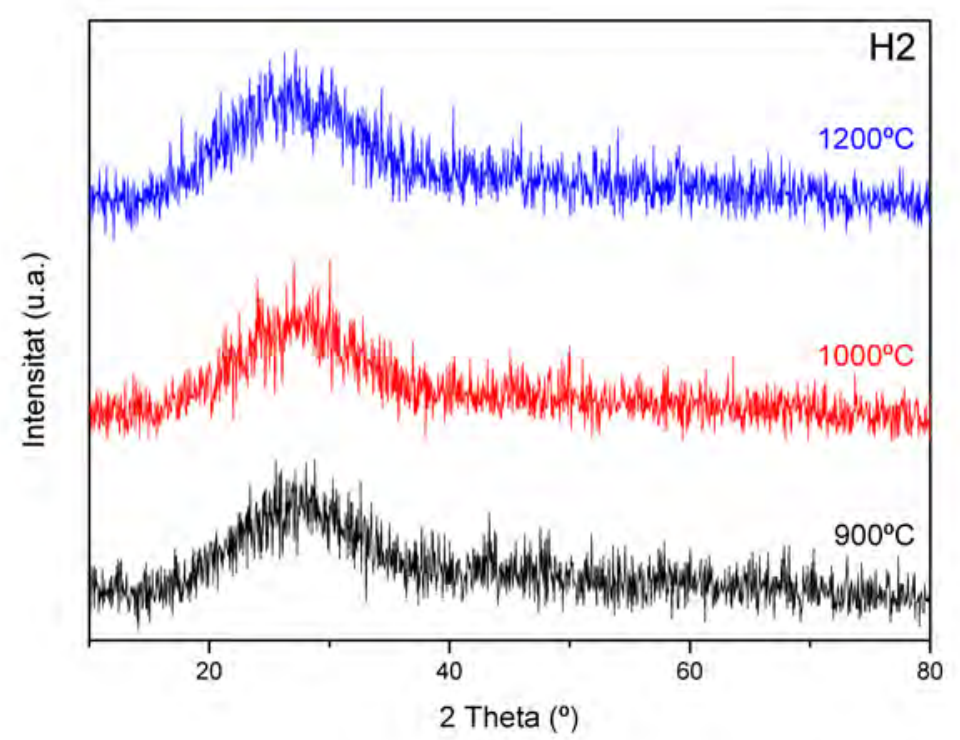

Figura 182 Difractograma de la composició H2 amb una hora de manteniment a 900, 1000 i 1200C.

\subsubsection{Sèrie J.}

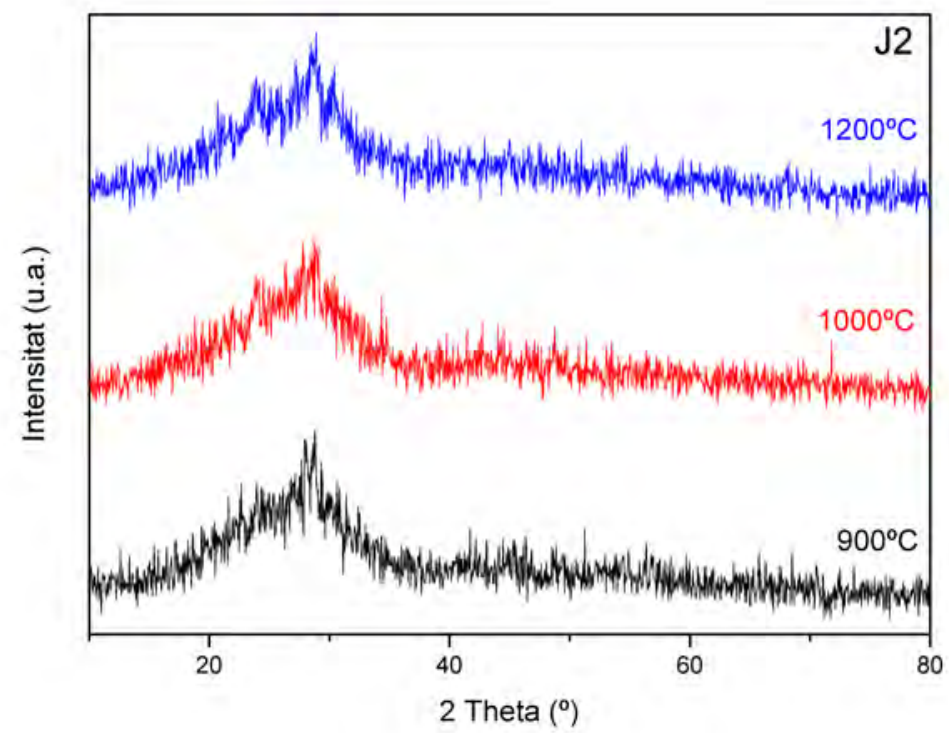

Figura 183 Difractograma de la composició J2 amb una hora de manteniment a 900, 1000 i 1200 ㄷ. 
7.5 Diagrames de Ginsberg, Raschin-Tschetveritkov i Lebedeva de totes les composicions per sèries.

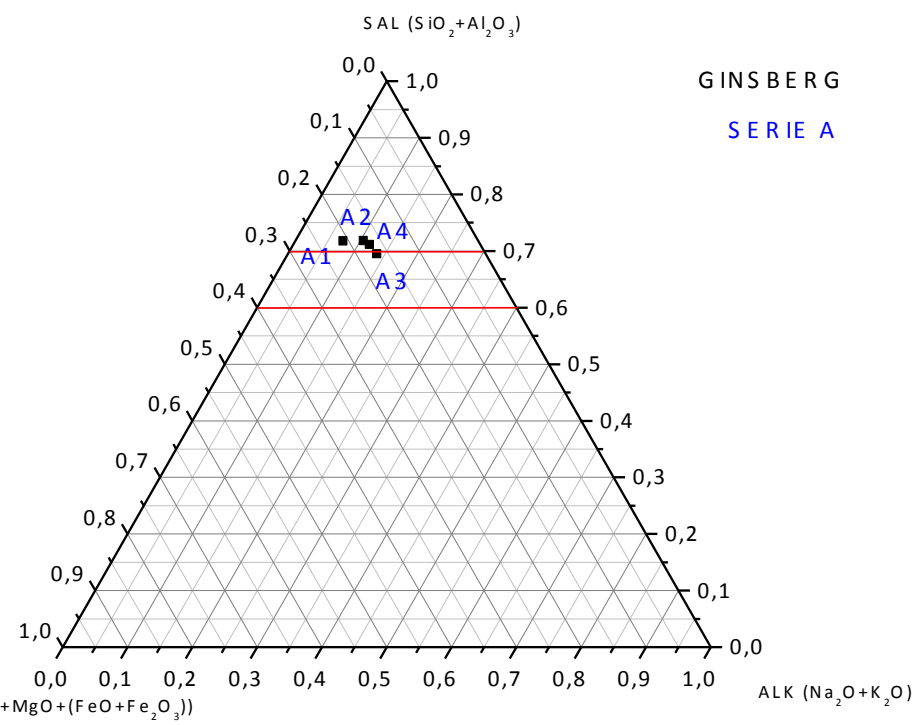

Figura 184 Diagrama de Ginsberg de la serie A.

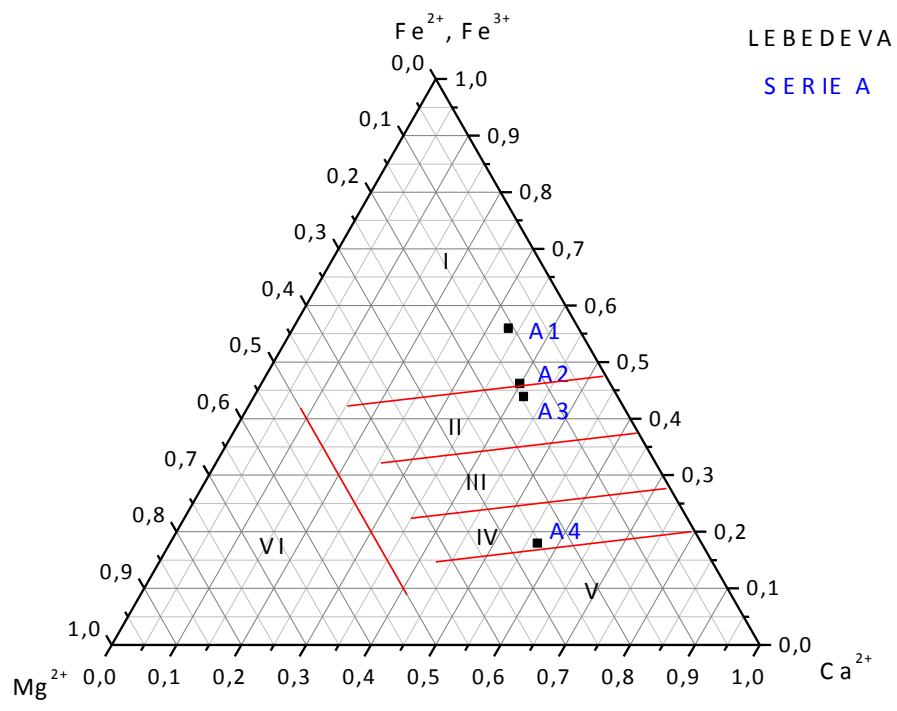

Figura 185 Diagrama de Lebedeva de la serie A. 
RECERCA DE NOUS VIDRIATS, FORMULATS A PARTIR DE RESIDUS, I OBTINGUTS PER MITJÀ DE NOVES TECNOLOGIES DE PROCESSAT CERÀMIC

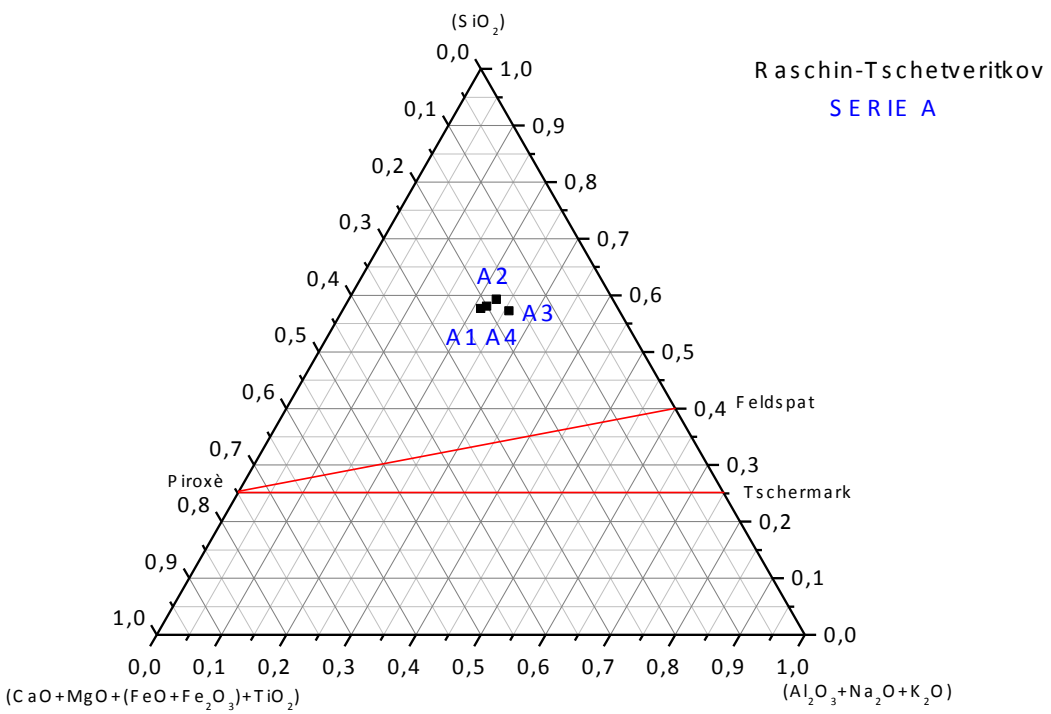

Figura 186 Diagrama de Raschin-Tschetveritkov de la serie A.

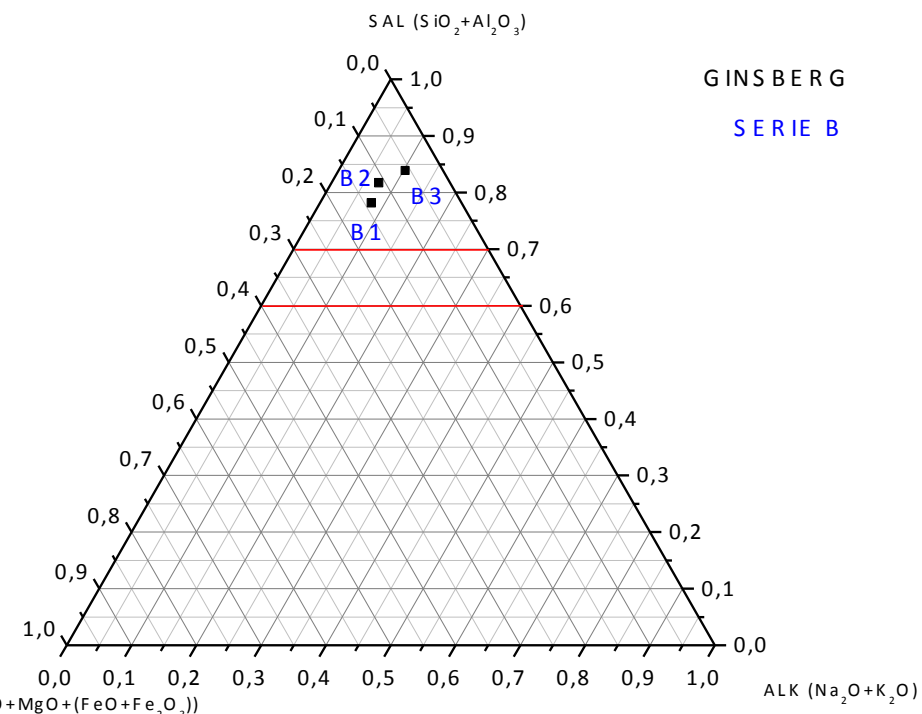

Figura 187 diagrama de Ginsberg de la serie B. 


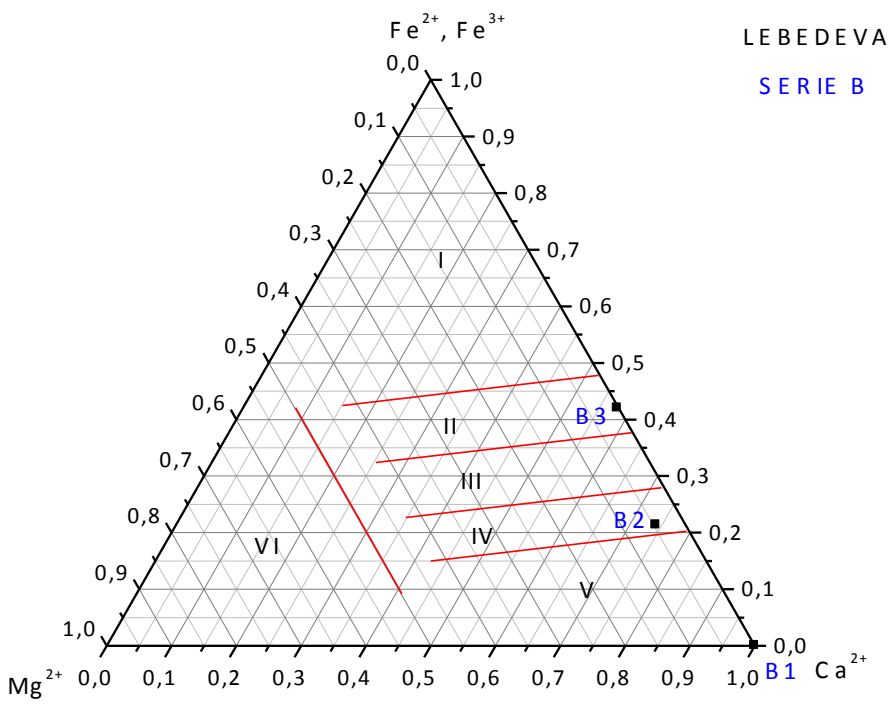

Figura 188 Diagrama de Lebedeva de la serie B.

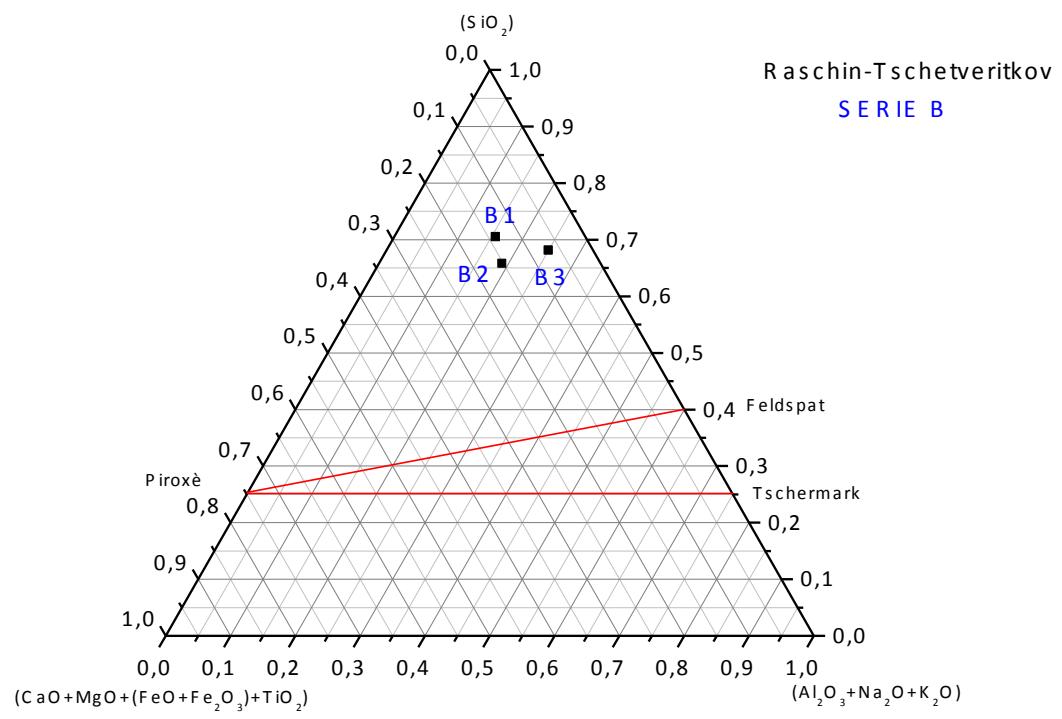

Figura 189 Diagrama de Raschin-Tschetveritkov de la serie B. 
RECERCA DE NOUS VIDRIATS, FORMULATS A PARTIR DE RESIDUS, I OBTINGUTS PER MITJÀ DE NOVES TECNOLOGIES DE PROCESSAT CERÀMIC

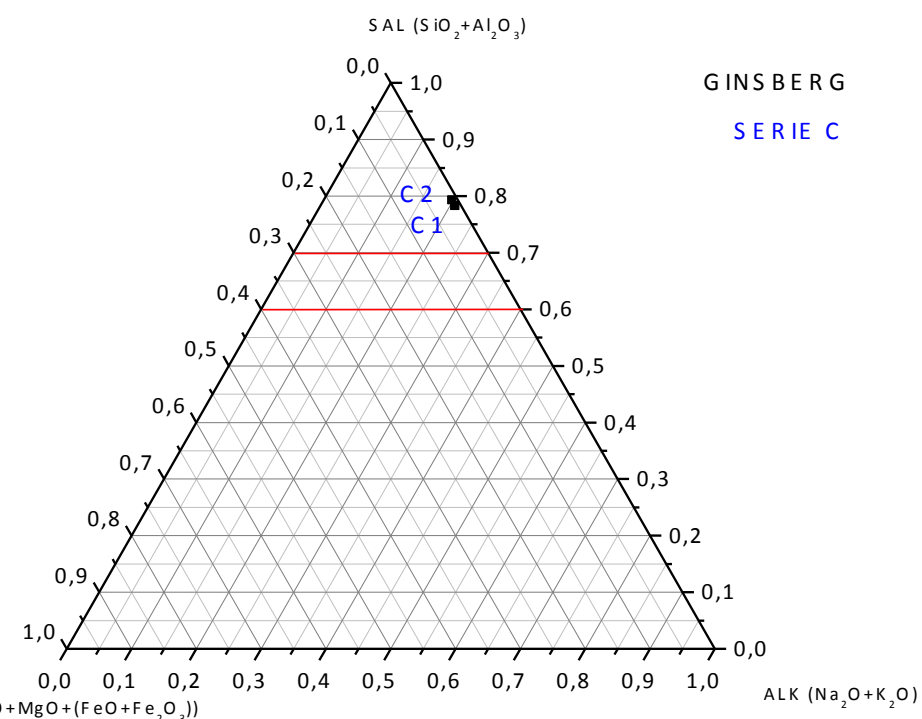

Figura 190 Diagrama de Ginsberg de la serie C.

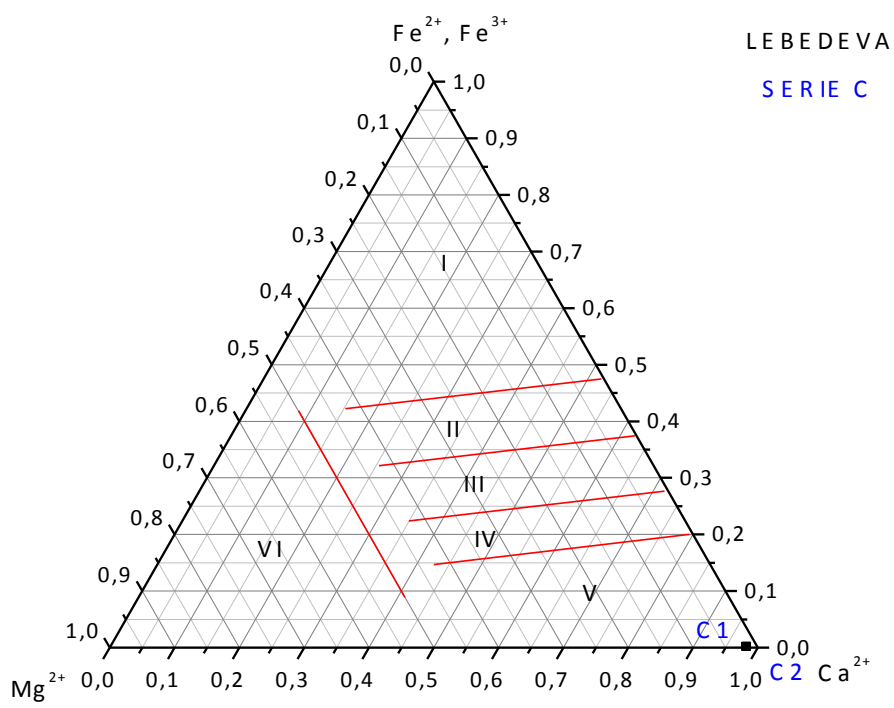

Figura 191 Diagrama de Lebedeva de la serie C. 


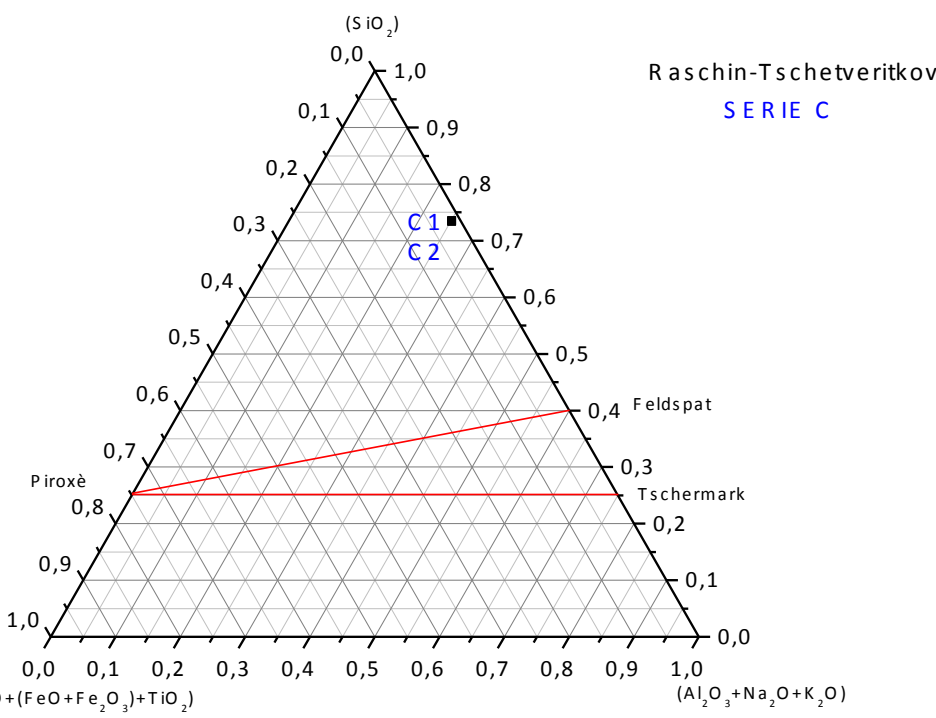

Figura 192 Diagrama de Raschin-Tschetveritkov.

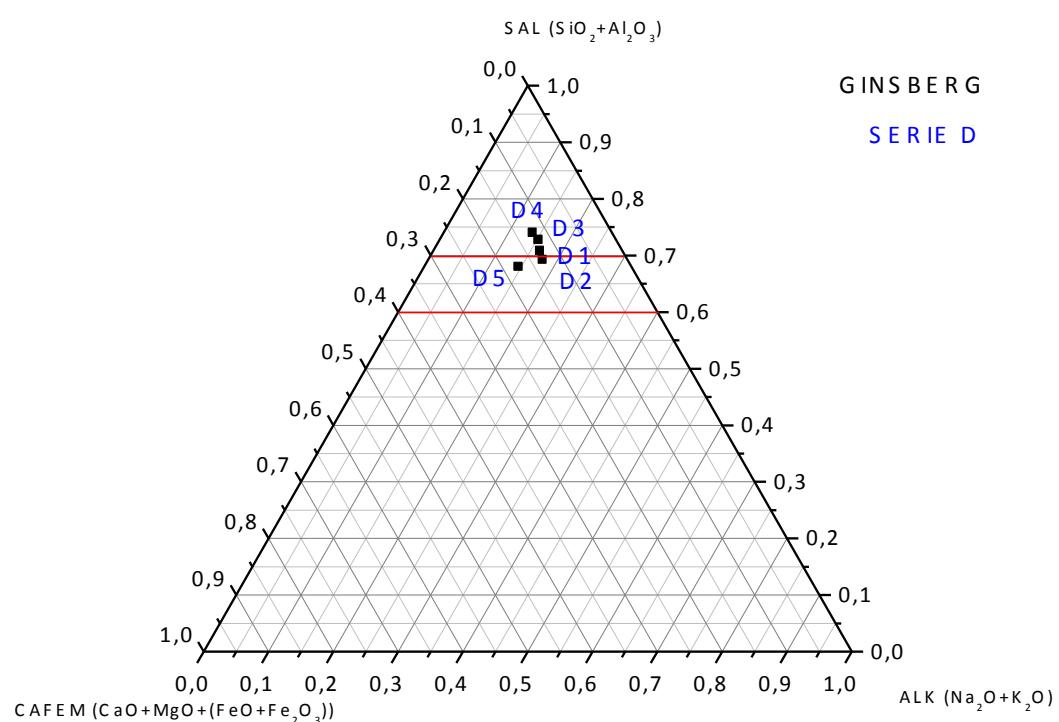

Figura 193 Diagrama de Ginsberg de la serie D. 
RECERCA DE NOUS VIDRIATS, FORMULATS A PARTIR DE RESIDUS, I OBTINGUTS PER MITJÀ DE NOVES TECNOLOGIES DE PROCESSAT CERÀMIC

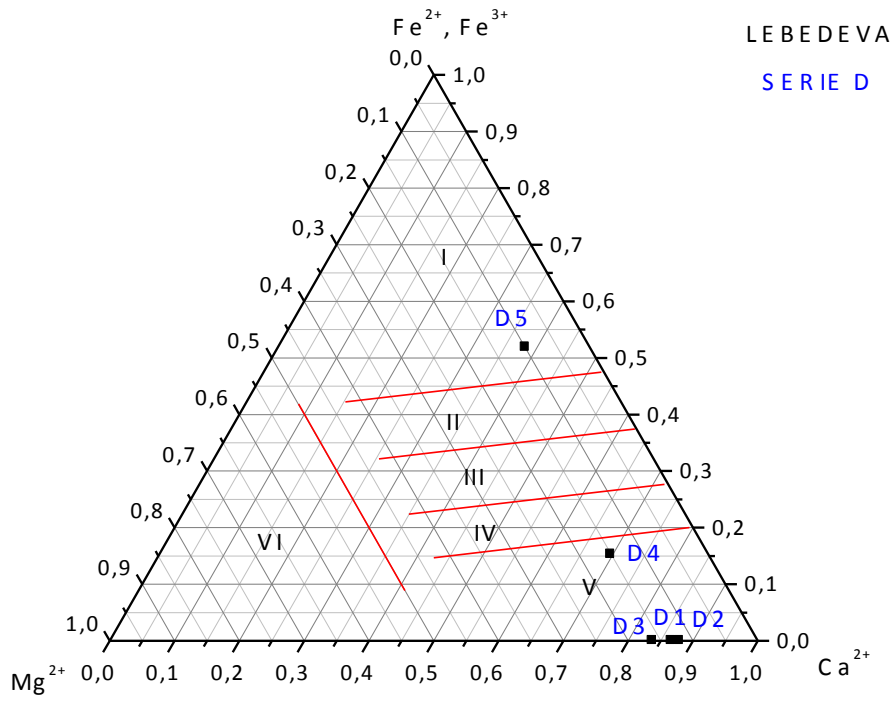

Figura 194 Digrama de Lebedeva de la serie D.

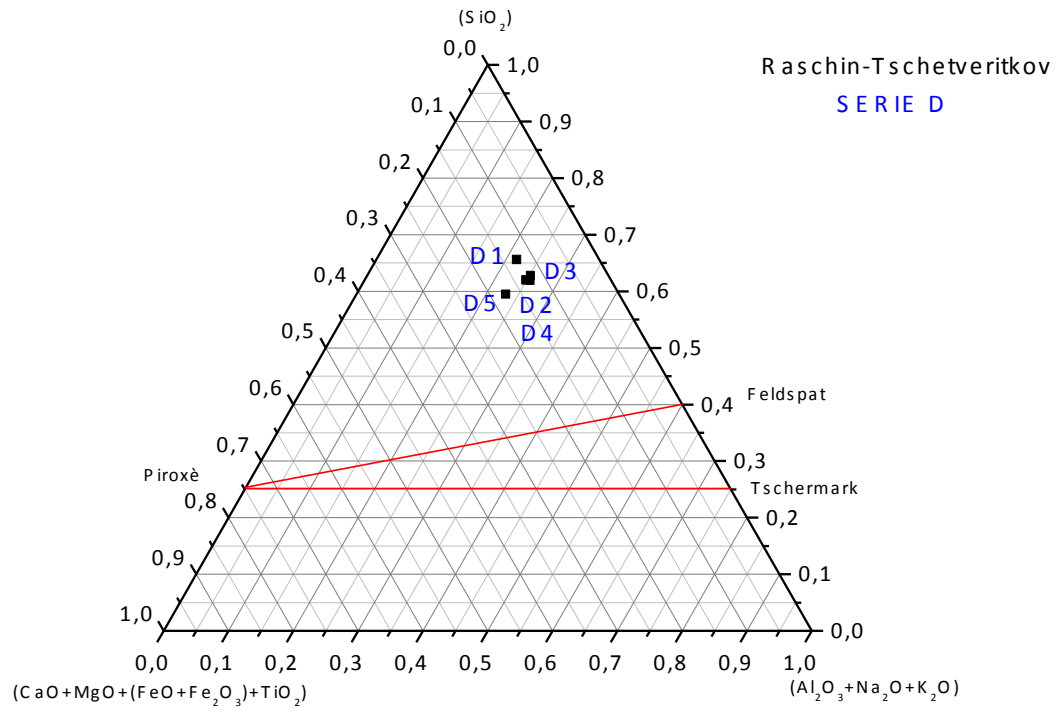

Figura 195 Diagrama de Raschin-Tschetveritkov de la serie D. 


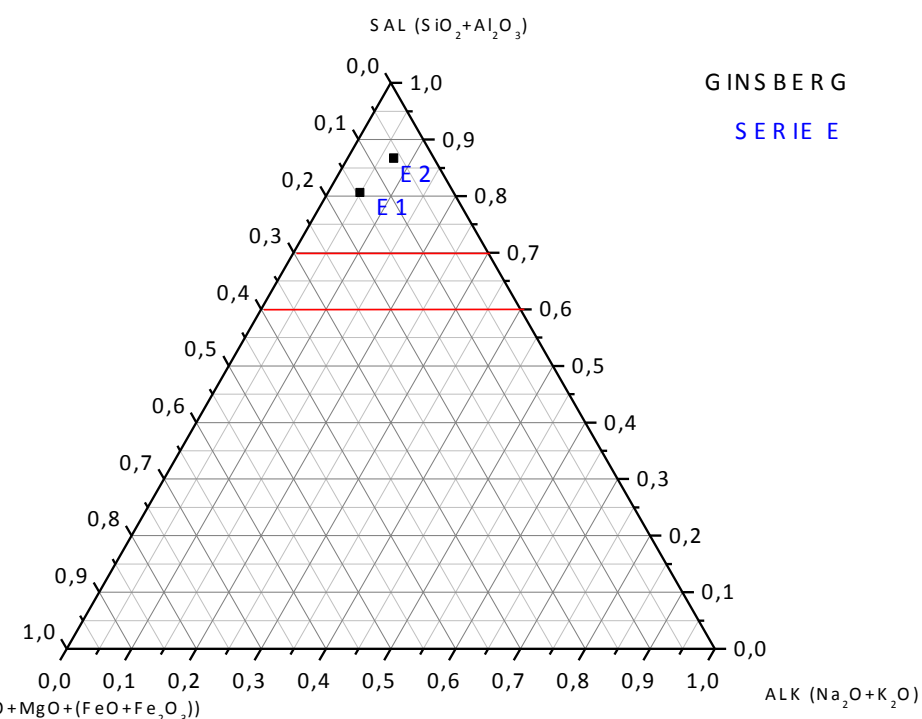

Figura 196 Diagrama de Ginsberg de la serie E.

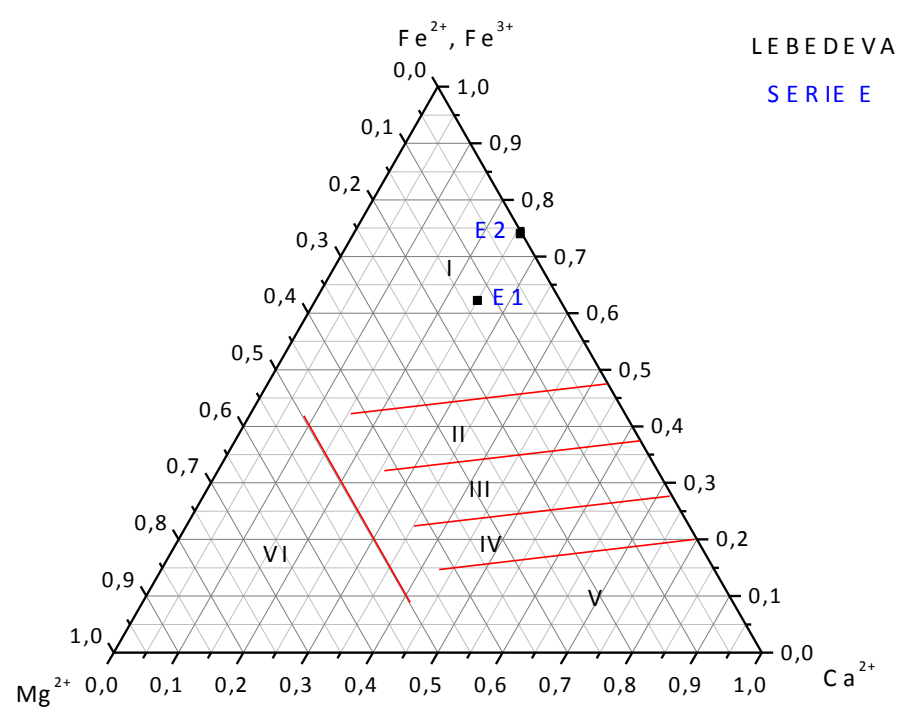

Figura 197 Diagrama de Lebedeva de la serie E. 
RECERCA DE NOUS VIDRIATS, FORMULATS A PARTIR DE RESIDUS, I OBTINGUTS PER MITJÀ DE NOVES TECNOLOGIES DE PROCESSAT CERÀMIC

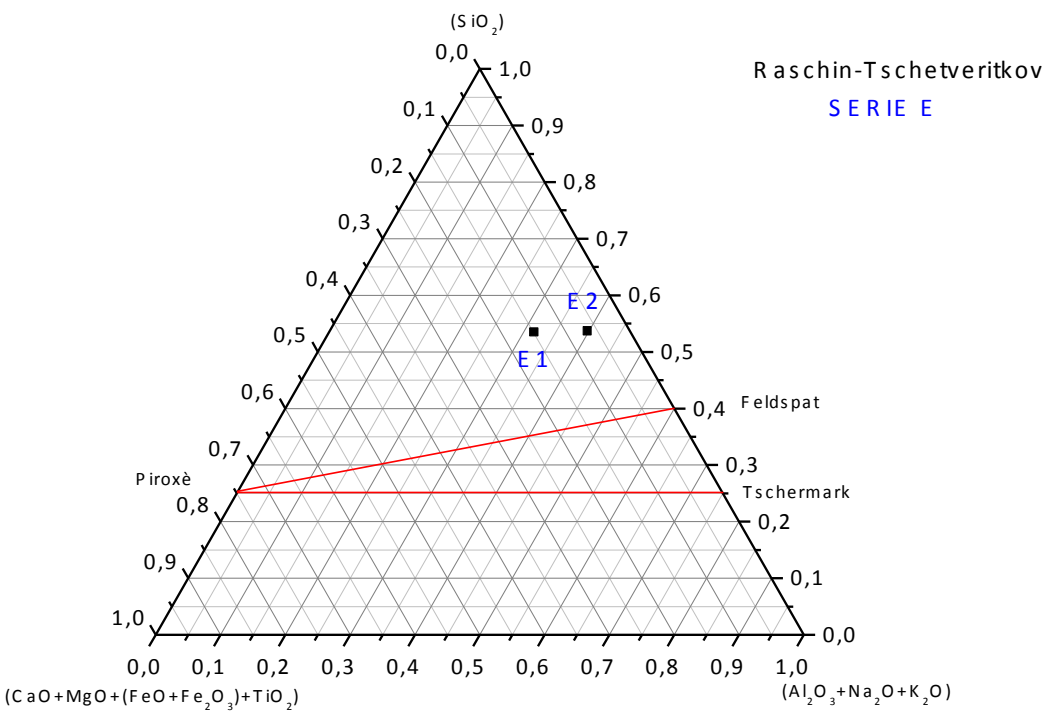

Figura 198 Diagrama de Raschin-Tschetveritkov de la serie E.

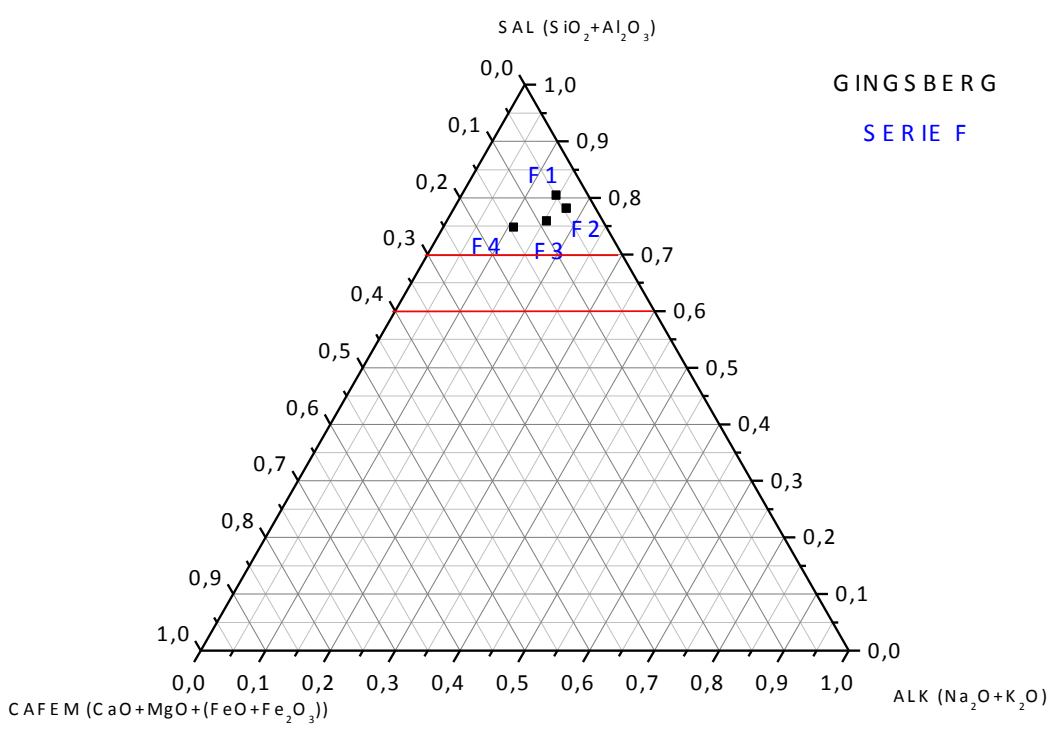

Figura 199 Diagrama de Ginsberg de la serie F. 


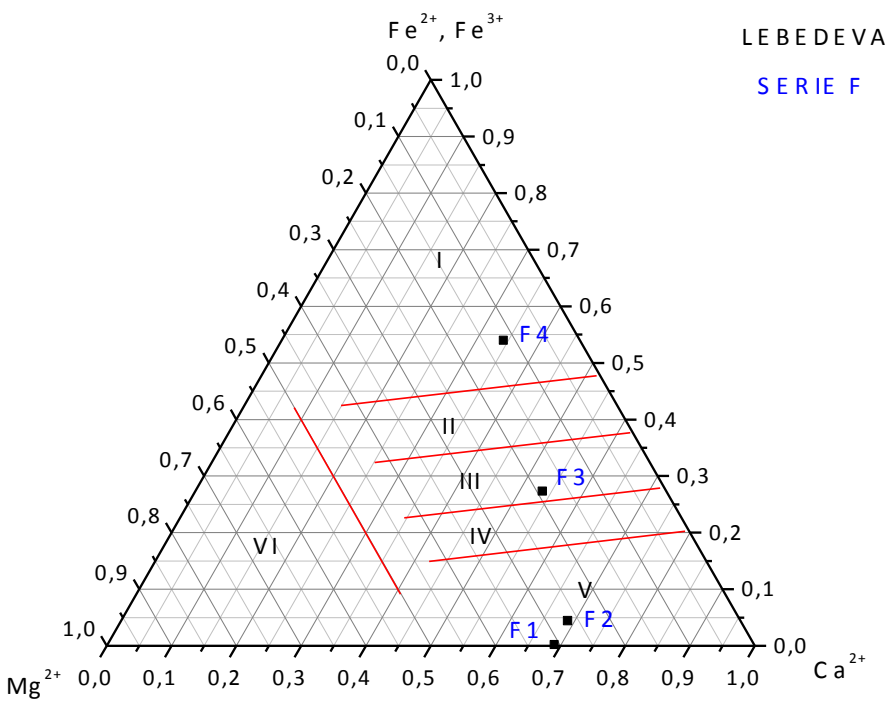

Figura 200 Diagrama de Lebedeva de la serie F.

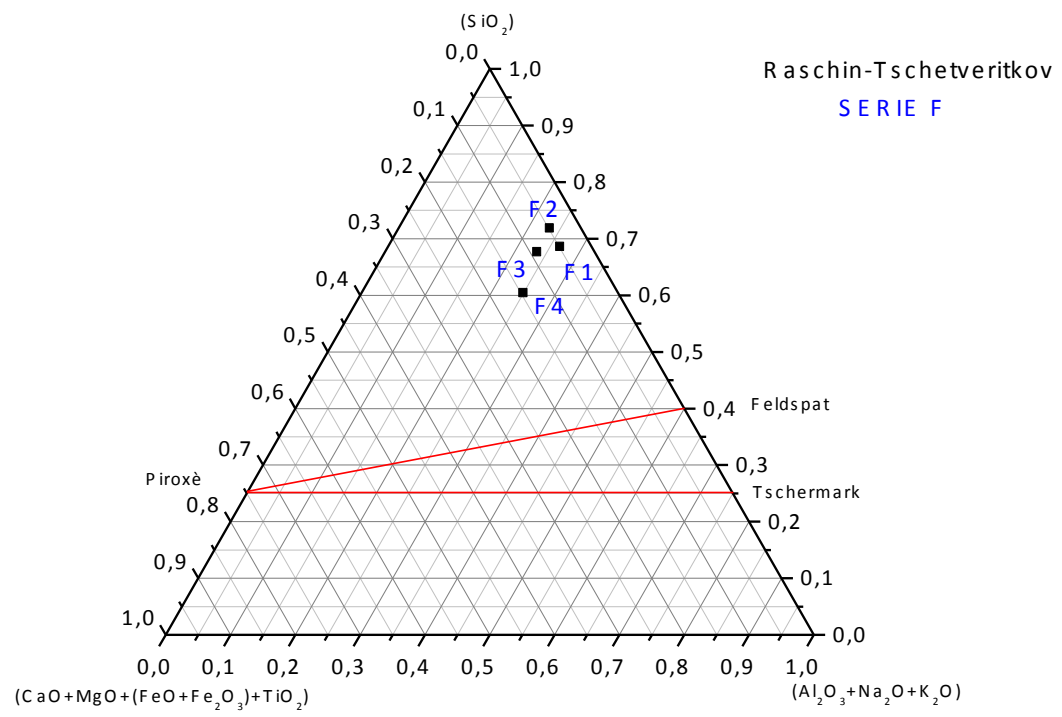

Figura 201 Diagrama de Raschin-Tschetveritkov de la serie F. 
RECERCA DE NOUS VIDRIATS, FORMULATS A PARTIR DE RESIDUS, I OBTINGUTS PER MITJÀ DE NOVES TECNOLOGIES DE PROCESSAT CERÀMIC

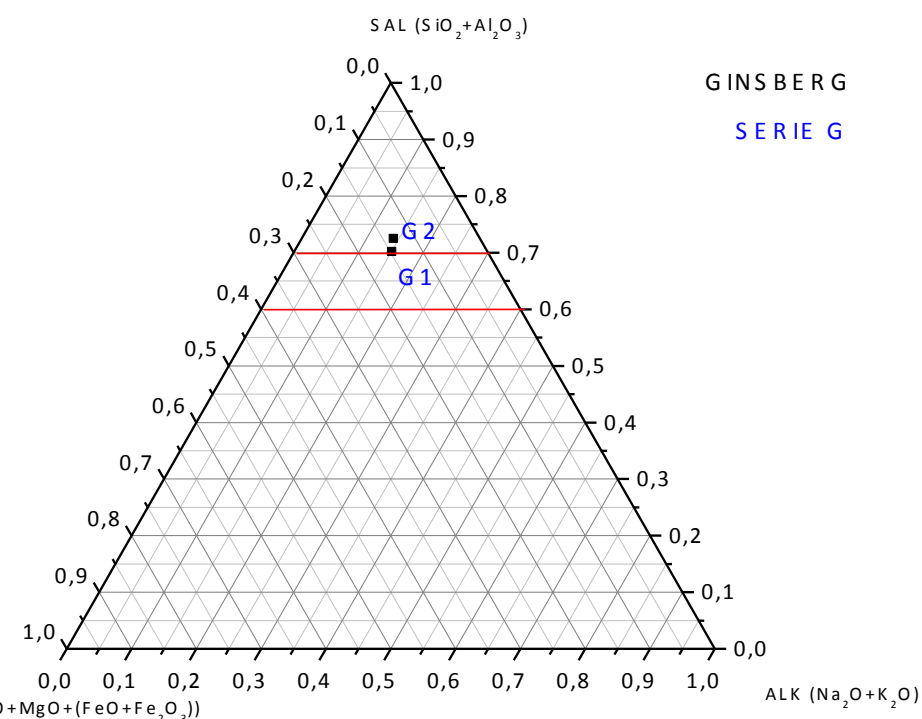

Figura 202 Diagrama de Ginsberg de la serie G.

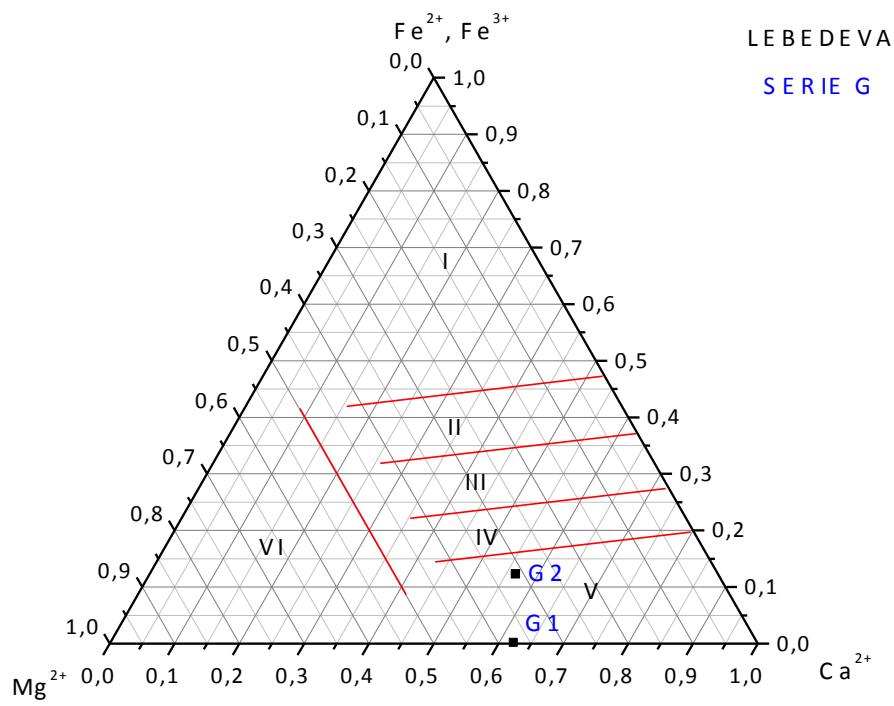

Figura 203 Diagrama de Lebedeva de la serie G. 


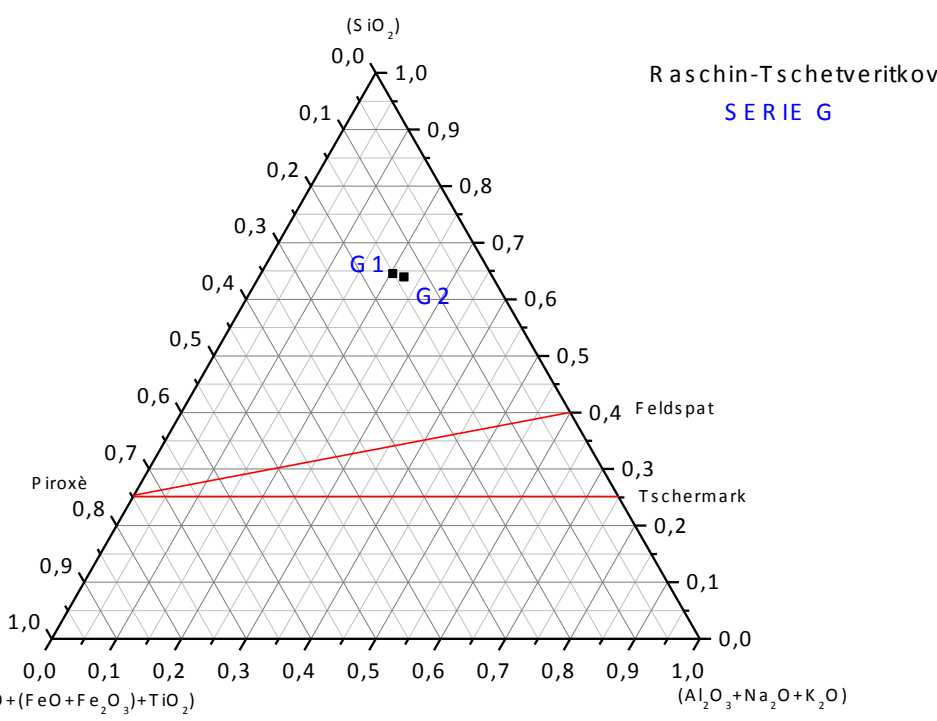

Figura 204 Diagrama de Raschin-Tschetveritkov de la serie G.

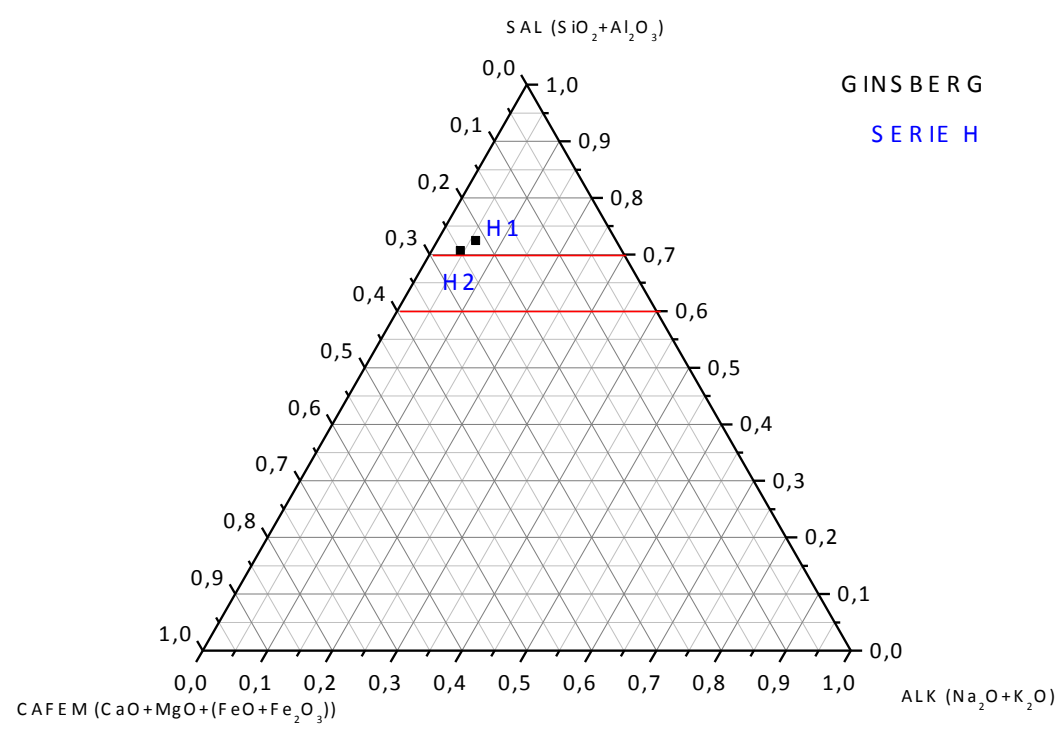

Figura 205 Diagrama de Ginsberg de la serie H. 
RECERCA DE NOUS VIDRIATS, FORMULATS A PARTIR DE RESIDUS, I OBTINGUTS PER MITJÀ DE NOVES TECNOLOGIES DE PROCESSAT CERÀMIC

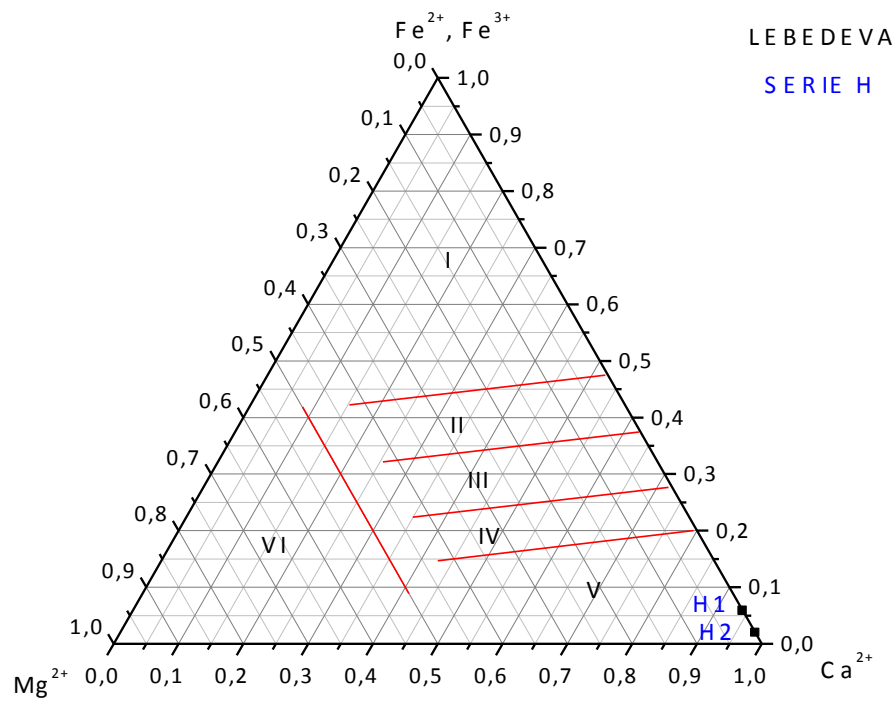

Figura 206 Diagrama de Lebedeva de la serie H.

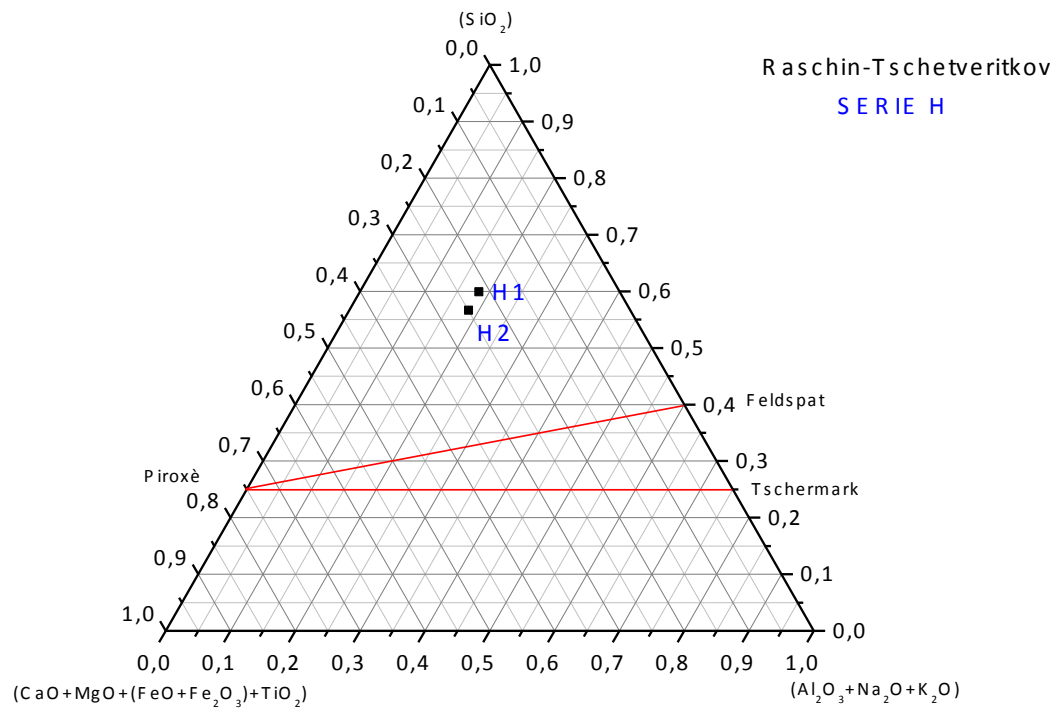

Figura 207 Diagrama de Raschin-Tschetveritkov de la serie H. 


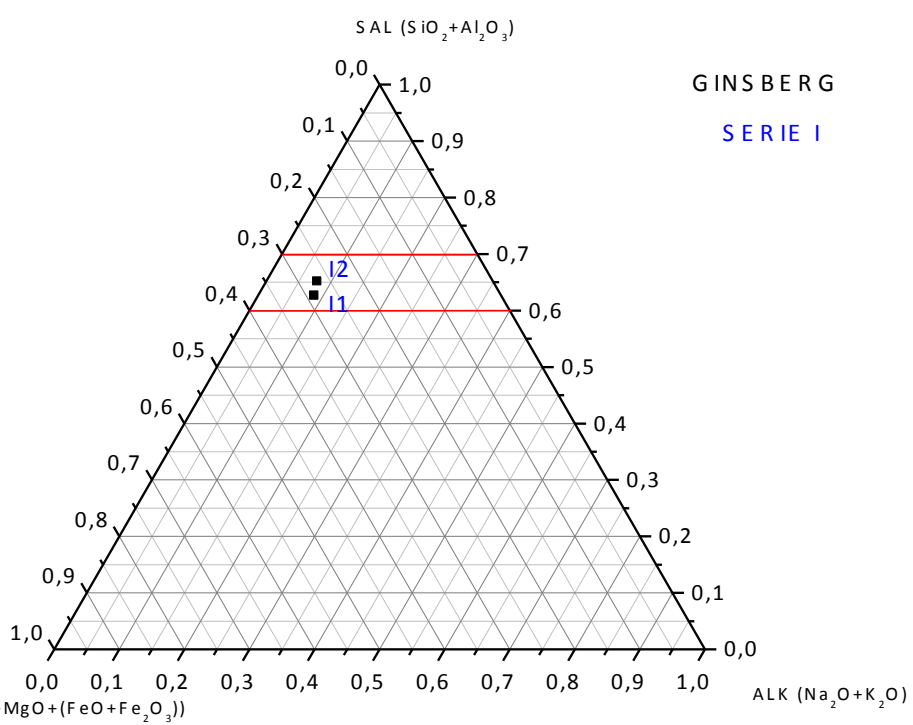

Figura 208 Diagrama de Ginsberg de la serie I.

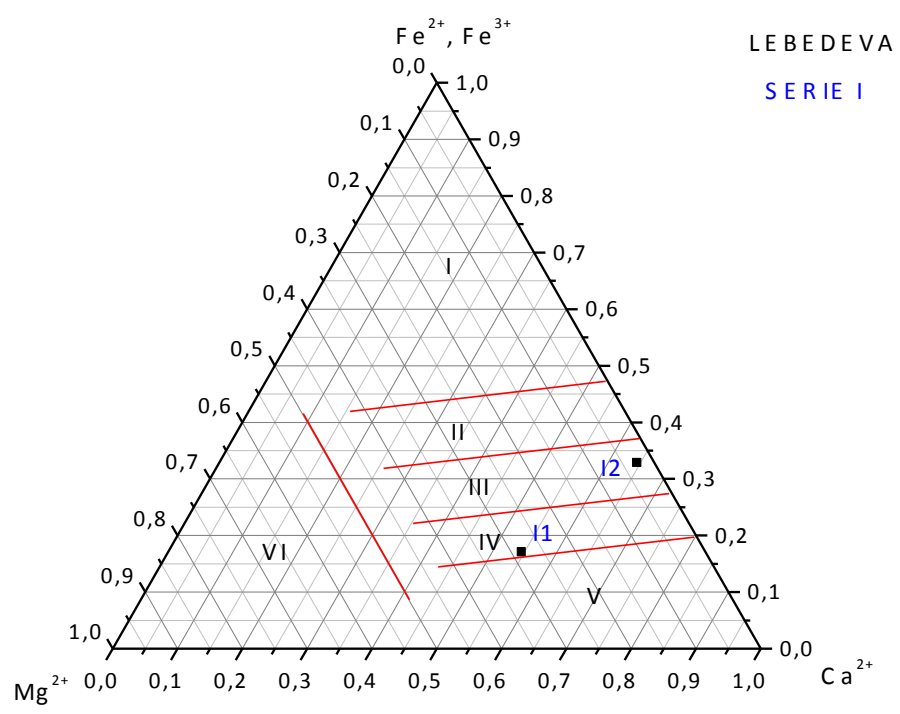

Figura 209 Diagrama de Lebedeva de la serie I. 
RECERCA DE NOUS VIDRIATS, FORMULATS A PARTIR DE RESIDUS, I OBTINGUTS PER MITJÀ DE NOVES TECNOLOGIES DE PROCESSAT CERÀMIC

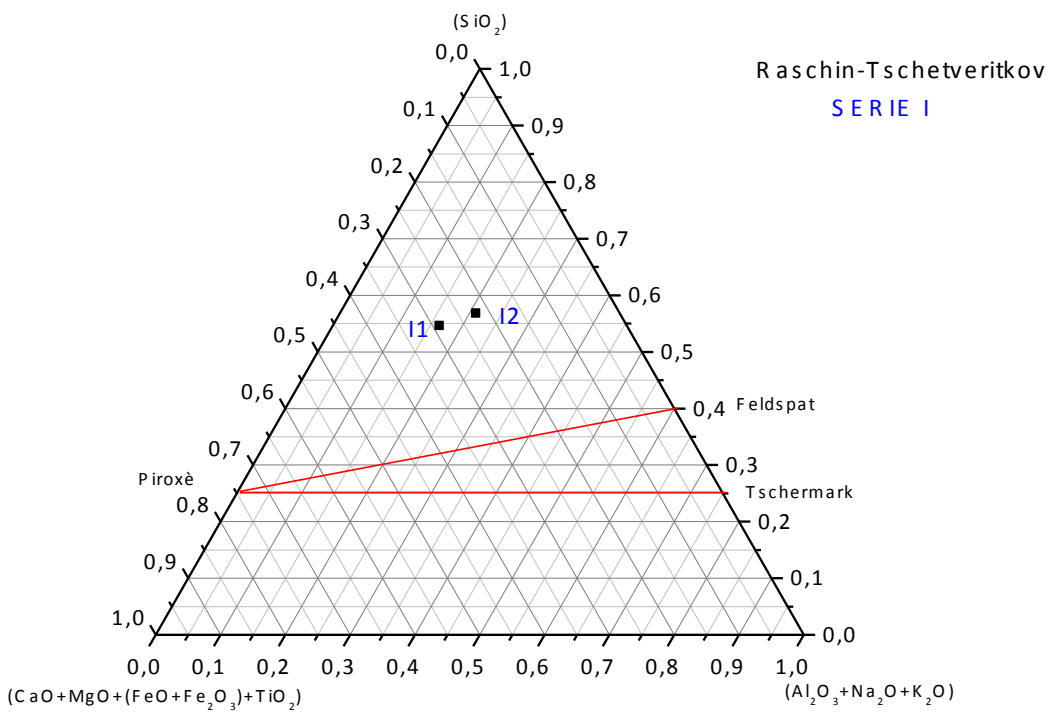

Figura 210 Diagrama de Raschin-Tschetveritkov de la serie I.

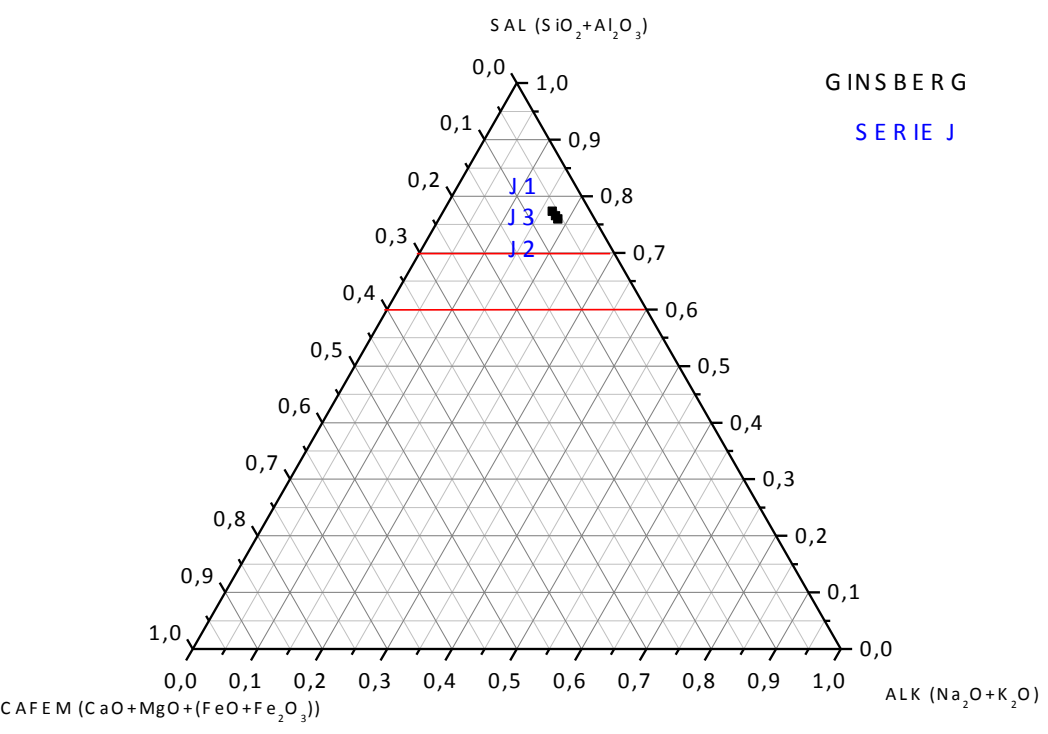

Figura 211 Diagrama de Ginsberg de la serie J. 


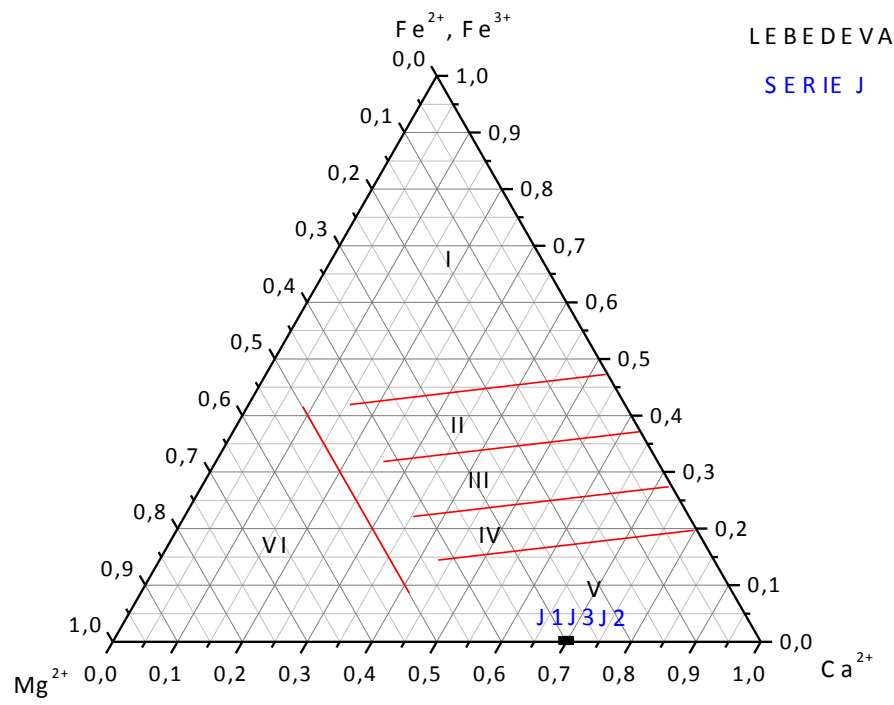

Figura 212 Diagrama de Lebedeva de la serie J.

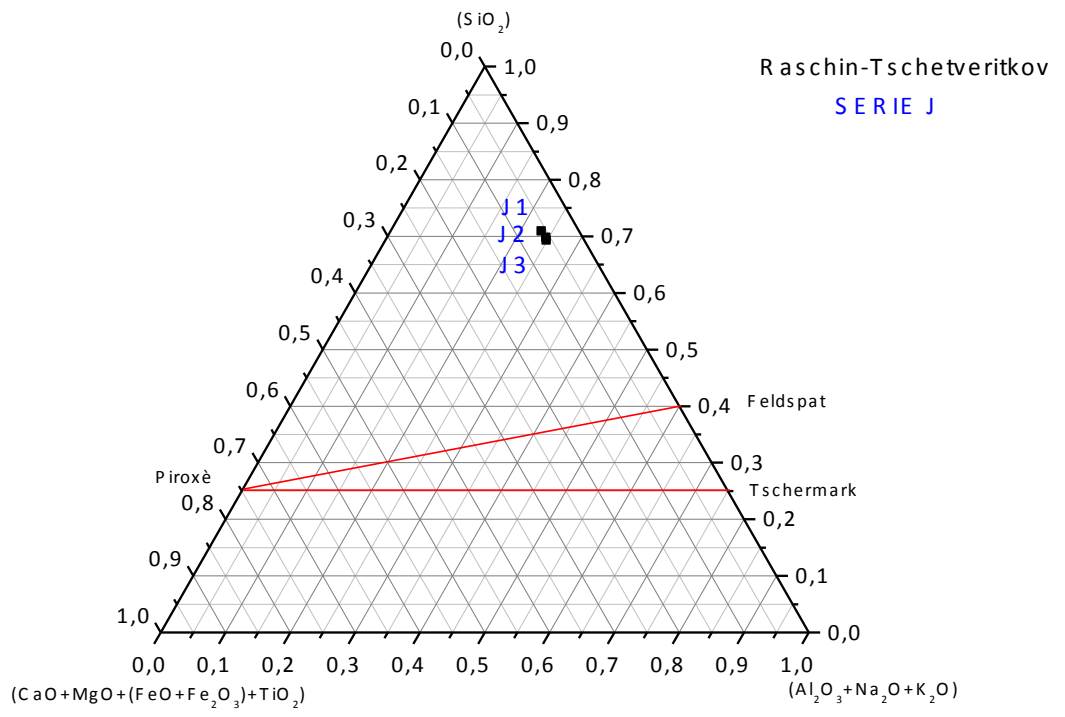

Figura 213 Diagrama de Raschin-Tschetveritkov de la serie J: 


\section{Bibliografia.}

[1] M. Aineto, A. Acosta, "Las escorias de la central térmica GICC ELCOGAS como materia prima para la síntesis de materiales vitrocerámicos Parte 1 : Comportamiento en fusión de las escorias GICC y obtención del vidrio original.," Boletín la Soc. Española Ceram. y Vidr., vol. 44, no. c, pp. 399-404, 2005.

[2] SACMI, Tecnología Cerámica Aplicada Vol.1. Castellón, 2004.

[3] M. Maggetti, J. Rosen, V. Serneels, "The Origin of 18th-19th Century TinGlazed Pottery from Lorraine, France," Archaeometry, vol. 57, no. 3, pp. 426$452,2015$.

[4] Ni. Centritto, "FRITAS," in Introdución a los esmaltes cerámicos, F. E. I. SL, Ed. 2005, pp. 57-60.

[5] T. Palomar, M. García-Heras, C. Saiz-Jiménez, C. Márquez, M. a. Villegas, "Patologías y estudio analítico de materiales procedentes de mosaicos de Carmona e Itálica,” Mater. Construcción, vol. 61, no. 304, pp. 629-636, 2011.

[6] A. Doménech-Carbó, M. T. Doménech-Carbó, "Electrochemical characterization of archaeological tin-opacified lead-alkali glazes and their corrosion processes," Electroanalysis, vol. 17, no. 21, pp. 1959-1969, 2005.

[7] F. Climent Montoliu , M. J. Fernandez Rodríguez, “Caracterización de esmaltes plúmbicos cerámicos mediante reflectometría , microscopía electrónica de barrido y microanálisis," Cerámica y Vidr., vol. 80, no. 3, pp. 77-80, 1994.

[8] R. J. Rincón, M. P. Benet, J. Juárez, C. Cabezón, J. M. Pedra, J. B. Carda, J. Martínez, "Desarrollo de esmaltes vitrocerámicos con propiedades antideslizantes para baldosas de gres porcelánico,” Qualicer, no. 1, pp. 331-344, 2008. 
[9] P. Jaquotot, a. Campillo, J. J. Reinosa, J. J. Romero, M. a. Bengochea, a. Esteban-Cubillo, J. Santarén, E. Aguilar, R. Pina, C. Pecharroman, J. S. Moya, J. F. Fernández, "Desarrollo de esmaltes nanoestructurados multifuncionales," Bol. la Soc. Esp. Ceram. y Vidr., vol. 48, no. 2, pp. 95-98, 2009.

[10] M. D. L. Parreño, "Pavimentos porcelánicos para utilización en espacios urbanos," Bol. Soc. Esp. Ceram. Vidr, vol. 48, no. 2, pp. 113-118, 2009.

[11] F. Lucas, a. Belda, F. J. Torres, J. Alarcón, "Estudio y caracterización de vidriados vitrocerámicos basados en piroxeno," Bol. la Soc. Esp. Ceram. y Vidr., vol. 43, no. 5, pp. 849-854, 2004.

[12] S. A. Ferro Spain, "Desarrollo de efectos cerámicos como acabados superficiales, mediante tecnología de inyección digital," Bol. Soc. Esp. Ceram. Vidr, vol. 51, no. 2, 2012.

[13] P. Fermo, G. Padeletti, “The Use of Nano-Particles to Produce Iridescent Metallic Effects on Ancient Ceramic Objects," J. Nanosci. Nanotechnol., vol. 12, no. 11, pp. 8764-8769, 2012.

[14] M. Fiske, "Iridescent and Manganese Crystalline Glazes," in Technology of Ceramics, Glaze Calc, 2014.

[15] C. Mañueco, “Aportaciones sobre la composición de los esmaltes, barnices y pastas de la porcelana del Buen Retiro. Nuevos datos documentales.," Cerámica y Vidr., pp. 181-186, 1808.

[16] A. Tunali, E. Ozel, S. Turan, "Production and characterisation of granulated frit to achieve anorthite based glass-ceramic glaze," J. Eur. Ceram. Soc., 2015.

[17] T. Manfredini, G. C. Pellacani, J.Ma. Rincón, Glass-ceramic materials, Editore, M. 1997.

[18] B. Stefanov, keramik-glasuren. Bauverlag, 1988. 
[19] Z. Strnad, P. Strnad, "Calculation of metastable two_liquid tie lines in ternary glass-forming systems.," Journal of the American Ceramic Society, vol. 61, no. 7-8. pp. 283-286, 1978.

[20] P. Boch , J.-C. Nièpce, Ceramic Materials : Processes, Properties, and Applications. 2010.

[21] I. D. E. Vicente, "Estudio de los mecanismos de nucleación y cristalización en vidrios obtenidos a partir de rocas basálticas canarias," 1992.

[22] R. Casasola, J.Ma. Rincón, M. Romero, "Glass-ceramic glazes for ceramic tiles: A review," J. Mater. Sci., vol. 47, no. 2, pp. 553-582, Oct. 2012.

[23] J. A. Rodríguez-Losada , I. Queralt Mitjans, "Las rocas volcánicas del SE español: Posibles aplicaciones en la industria vitroceramica y petrúrgica," in Recursos naturales y medio ambiente en el sureste peninsular, 1997, pp. 161167.

[24] L. Barbieri, A. M. Ferrari, I. Lancellotti, C. Leonelli, J. M. Rinco, "Formulated from Waste Products," vol. 20, pp. 2515-2520, 2000.

[25] L. M. Schabbach, F. Andreola, E. Karamanova, I. Lancellotti, A. Karamanov, L. Barbieri, "Integrated approach to establish the sinter-crystallization ability of glasses from secondary raw material," J. Non. Cryst. Solids, 2011.

[26] R. D. Rawlings, J. P. Wu, A. R. Boccaccini, "Glass-ceramics: Their production from wastes-A Review," Journal of Materials Science. 2006.

[27] M. J. Cabrera, V. Montís, A. Foó, P. Balfagón, “Obtención de esmaltes de aspecto metálico en baldosas fabricadas por monococción," Qualicer, pp. 261$274,2006$. 
[28] G. A. Rosales Sosa, T. Poirier, J. Lira-Olivares, J. B. Carda Castelló, "Effect of Fluxing Additives in Iron-rich Frits and Glazes in the Fe2O3-SiO2-CaO-A12O3 System," Interceram, vol. 62, no. 2, pp. 126-130, 2013.

[29] F. Navarro, El vidrio. Consejo Superior de Investigaciones Científicas, 1991.

[30] R. P. Hevia, C. Gil, J. B. Carda, "Mineral treatment of spodumene in the ceramic industry. Characterization and technological use," Qualicer, no. 1, pp. 55-60, 2006.

[31] J. Nie, J. Zhang, J. Bei, G. Chen, "Optical properties of zinc barium silicate glasses," J. Non. Cryst. Solids, vol. 354, no. 12-13, pp. 1361-1364, Feb. 2008.

[32] J. Rodriguesa, A. M. Bernardin, "Desarrollo de esmaltes blancos de TiO2 para baldosas cerámicas: Influencia de la fusión de la frita y aplicación del esmalte," in Qualicer, 2010, no. 2, pp. 1-8.

[33] A. Barba, "From chemical engineering to ceramic technology: A review of research at the Instituto de Tecnología Cerámica," Boletin de la Sociedad Espanola de Ceramica y Vidrio, vol. 44, no. 3. pp. 155-168, 2005.

[34] A. Escardino, “Cerámica y Vidrio La innovación tecnológica en la industria cerámica de Castellón,” vol. 43, no. c, pp. 43-51.

[35] Y. Elkadi, A. Agrawal, T. Holdmann, "Electrochromic safety glazing,” 2003.

[36] R. a. Dorey, S. a. Rocks, F. Dauchy, D. Wang, F. Bortolani, E. Hugo, "Integrating functional ceramics into microsystems," J. Eur. Ceram. Soc., vol. 28, no. 7, pp. 1397-1403, Jan. 2008.

[37] M. Derda, "Vehicle glazing," 2010.

[38] J. B. Núñez, J., Pedra, J M; Peiro, M., Gómez J.J.; Chiva, L., Carda, 
"Investigaciones de interés industrial sobre baldosas cerámicas," Técnica industrial, vol. 252, pp. 26-35, 2004.

[39] D. Sannino, V. Vaiano, G. Sarno, P. Ciambelli, "Smart Tiles for the Preservation of Indoor Air Quality,” vol. 32, no. x, pp. 355-360, 2013.

[40] O. Ruiz, F. Sanmiguel, C. Gargori, F. Galindo, G. Monrós, "Study of the photocatalytic degradability of ceramic glazes," no. 1, pp. 15-31.

[41] K. Hashimoto, H. Irie, A. Fujishima, " $\mathrm{TiO}_{2}$ Photocatalysis : A Historical Overview and Future Prospects,” vol. 44, no. 12, pp. 8269-8285, 2006.

[42] K. D. Sanderson, L. Gb, T. Darrell, L. Gb, D. P. Fitzgerald, M. Gb, L. Palmer, "Coated glazing," no. 19. 2011.

[43] J. J. Reinosa, J. J. Romero, M. A. de la Rubia, A. del Campo, J. F. Fernández, "Inorganic hydrophobic coatings: Surfaces mimicking the nature," Ceram. Int., vol. 39, no. 3, pp. 2489-2495, 2013.

[44] L. C. Fenollar, J. R. Valiente, C. V. Apellaniz, V. F. Serra, "M.A.B. Revestimientos vítreos con propiedades bactericidas y fungicidas," Boletín la Soc. Española Ceram. y Vidr., 2012.

[45] T. Kronberg, A. C. Ritschkoff, R. Mahlberg, J. Mannila, M. Kallio, A. Vesa, L. Hupa, "Soil-resistant surfaces for traditional ceramics," J. Eur. Ceram. Soc., vol. 27, no. 2-3, pp. 1775-1780, Jan. 2007.

[46] P. Abad Mejía , C. M. Restrepo Restrepo, "Desarrollo de propiedades bactericidas en esmaltes para cerámica sanitaria," Rev. Acad. Colomb. Cienc, vol. 30, no. 116, pp. 387-396, 2006.

[47] J. F. Noguera, A. Moreno, A. Gozalbo, M. J. Orts, "Desarrollo de esmaltes cerámicos con propiedades bactericidas y fungicidas," Qualicer, pp. 1-9, 2010. 
[48] V. V. Vermol, K. Kamsah, O. H. Hassan, R. Anwar, "A study on porcelain anti slip tile design," 2011 IEEE Colloq. Humanit. Sci. Eng. CHUSER 2011, no. Chuser, pp. 121-124, 2011.

[49] M. J. Pérez, J. M. Saiz, F. Moreno, "Emission curves vs charging conditions in phosphorescent pigments embedded in sintered glass: Is there a reciprocity law?," Opt. Commun., vol. 285, no. 21-22, pp. 4413-4419, Oct. 2012.

[50] C. Ferrari, A. Libbra, A. Muscio, C. Siligardi, "Design of ceramic tiles with high solar reflectance through the development of a functional engobe," Ceram. Int., vol. 39, no. 8, pp. 9583-9590, Dec. 2013.

[51] F. C. Figueira A. M. Bernardina, "Baldosas vitrocerámicas lsa fabricadas por prensado de polvo," Qualicer, no. 1, pp. 1-10, 2010.

[52] A. M. Berto, "Ceramic tiles: Above and beyond traditional applications," J. Eur. Ceram. Soc., vol. 27, no. 2-3, pp. 1607-1613, Jan. 2007.

[53] I. Hutchings, "Ink-jet printing for the decoration of ceramic tiles: technology and opportunities," Actas de QUALICER, pp. 1-16, 2010.

[54] D. Verucchi, M. Cavedoni, "Pigmented ceramic inks," Ceram. World Rev., vol. 21, no. 91, pp. 66-69, 2011.

[55] I. Corni, M. P. Ryan, A. R. Boccaccini, "Electrophoretic deposition: From traditional ceramics to nanotechnology," J. Eur. Ceram. Soc., vol. 28, no. 7, pp. 1353-1367, Jan. 2008.

[56] A. M. Querol, J. V. Tomás, R. Vicent, "Nuevo dispositivo de deposición digital de solidos K9 solidjet," Cerámica y Vidr., vol. marzo-abri, pp. 11-14, 2014.

[57] G. Torrecid, "Innovadoras soluciones digitales para generar las nuevas tendencias 
de futuro en el sector cerámico," Cerámica y Vidr., vol. marzo-abri, pp. 5-9, 2013.

[58] G. Monrós, M. Llusar, A. García, C. Gargori, R. Galindo, "Development of New Ceramic Dyes,” Adv. Sci. Technol., vol. 68, pp. 182-193, 2010.

[59] E. Stobierska, M. M. Bućko, J. Lis, K. Kuźmińska, "Colour Properties of Y2O3A12O3-Cr2O3 Pigments as a Result of Precursors Morphology," Adv. Sci. Technol., vol. 68, pp. 202-207, 2011.

[60] M. Dondi, M. Blosi, D. Gardini, C. Zanelli, "Ceramic pigments for digital decoration inks: An overview," CFI Ceram. Forum Int., vol. 89, no. 8-9, pp. 1$12,2012$.

[61] L. Oliveira, T. Todorov, E. Chassaing, D. Lincot, J. Carda, P. Escribano, "CIGSS films prepared by sol-gel route," Thin Solid Films, vol. 517, no. 7, pp. 2272-2276, Feb. 2009.

[62] J. Martínez, I. Marinova, R. J. Rincón, J. S. Valencia, M. Peiró, I. Núñez, E. Navarro, J. B. Carda, "Síntesis y caracterización de esmaltes de alto índice de refracción y dureza," QUALICER, vol. 249, no. 1, pp. 249-260, 2006.

[63] T. Todorov, M. Kita, J. Carda, P. Escribano, "Cu2ZnSnS4 films deposited by a soft-chemistry method," Thin Solid Films, vol. 517, no. 7, pp. 2541-2544, Feb. 2009.

[64] D. Gabaldón-Estevan M. P. Hekkert, "How Does the Innovation System in the Spanish Ceramic Tile Sector Function?," Boletín la Soc. Española Cerámica y Vidr., vol. 52, no. 3, pp. 151-158, Jul. 2013.

[65] R. Lahoz, G. F. de la Fuente, J. M. Pedra, J. B. Carda, "Laser Engraving of Ceramic Tiles," Int. J. Appl. Ceram. Technol., vol. 8, no. 5, pp. 1208-1217, Sep. 2011. 
[66] J. Lawrence, L. Li, "Wettability characteristics of an $\mathrm{Al}_{2} \mathrm{O}_{3} / \mathrm{SiO}_{2}$-based ceramic modified with $\mathrm{CO}_{2}$, Nd:YAG, excimer and high-power diode lasers," J. Phys. D. Appl. Phys., vol. 32, no. 10, pp. 1075-1082, May 1999.

[67] C. Ma, S. Bai, X. Peng, Y. Meng, "Improving hydrophobicity of laser textured SiC surface with micro-square convexes," Appl. Surf. Sci., vol. 266, pp. 51-56, 2013.

[68] F. Gutiérrez Mora, A. Domínguez-Rodríguez, V. V Lennikov, G. F. de la Fuente, "Influence of Thermal Effects Produced by Laser Treatment on the Tribological Behavior of Porcelain Ceramic Tiles," Key Eng. Mater., vol. 423, pp. 41-46, 2009.

[69] J. Gurauskis, V. Lennikov, G. F. de la Fuente, R. I. Merino, "Laser-assisted, crack-free surface melting of large eutectic ceramic bodies," J. Eur. Ceram. Soc., vol. 31, no. 7, pp. 1251-1256, Jun. 2011.

[70] R. K. Singh, D. Kumar, "Pulsed laser deposition and characterization of high-Tc YBa2Cu3O7 - x superconducting thin films," Mater. Sci. Eng. R Reports, vol. 22, no. 4, pp. 113-185, Apr. 1998.

[71] R. Pascual, A.; Fortanet, E.; Carda, J.B.; Pavlov, R.; Pedra, J.M.; De la Fuente, G.F.; Estepa, L.C.; Lahoz, "Decoración de baldosas cerámicas mediante tecnología láser," Qualicer, 2004.

[72] J. W. Restrepo , E. Gómez, Maryory Astrid, "Marcado con láser sobre cerámica vidriada por aporte superficial de un pigmento de cobalto," EIA, vol. 9, pp. 113$120,2008$.

[73] B. Qian, Z. Shen, "Laser sintering of ceramics," J. Asian Ceram. Soc., vol. 1, no. 4, pp. 315-321, Dec. 2013.

[74] W. Biegel, R. Klarmann, B. Stritzker, B. Schey, M. Kuhn, "Pulsed laser deposition and characterization of perovskite thin films on various substrates," Appl. Surf. Sci., vol. 168, no. 1-4, pp. 227-233, Dec. 2000. 
[75] A. S. Krasnikov, A. I. Berezhnoi, L. I. Mirkin, "Structure and properties of ceramic materials after laser treatment," Glas. Ceram. (English Transl. Steklo $i$ Keramika), vol. 56, no. 5-6, pp. 172-176, 1999.

[76] J. 1. Peña, J. C. Díez, G. F. de la Fuente, R. L. Merino, S. V. M. Orera U. Becker, Kuch, H. Opower, "La fusión zonal láser: un método versátil para el procesado de materiales avanzados," Bol. la Soc. Esp. Ceram. y Vidr., vol. 36, no. 2, pp. 132-136, 1997.

[77] a. Jonker, J. H. Potgieter, "An evaluation of selected waste resources for utilization in ceramic materials applications," J. Eur. Ceram. Soc., vol. 25, no. 13, pp. 3145-3149, Aug. 2005.

[78] S. N. Monteiro, J. Alexandre, J. I. Margem, R. Sánchez, C. M. F. Vieira, "Incorporation of sludge waste from water treatment plant into red ceramic," Constr. Build. Mater., vol. 22, no. 6, pp. 1281-1287, Jun. 2008.

[79] R. R. Menezes, H. G. M. Neto, L. N. L. Santana, H. L. Lira, H. S. Ferreira, G. a. Neves, "Optimization of wastes content in ceramic tiles using statistical design of mixture experiments,” J. Eur. Ceram. Soc., vol. 28, no. 16, pp. 3027-3039, Dec. 2008 .

[80] F. Andreola, L. Barbieri, F. Bondioli, A. M. Ferrari, V. Vignolese, R. Emilia, V. Amendola, "Valorization of Rice Husk Ash as Secondary Raw Material in the Ceramic Industry," proc. 10th Int. Conf. Eur. Ceram. Soc. (ECERS)., vol. 1798, p. $2007,2015$.

[81] S. Naganathan, H. A. Razak, S. N. A. Hamid, "Properties of controlled lowsrength material made using industrial waste incineration bottom ash and quarry dust," Mater. Des., vol. 33, pp. 56-63, 2012.

[82] E. H. Ishida, "Canalización de las fuerzas de la naturaleza- Los materiales conscientes del ser humano y de la tierra pueden crear nuevas olas." pp. 1-25, 1985. 
[83] A. a. Shakir, S. Naganathan, K. N. Mustapha, "Properties of bricks made using fly ash, quarry dust and billet scale," Constr. Build. Mater., vol. 41, pp. 131-138, Apr. 2013.

[84] S. N. Monteiro, C. M. F. Vieira, "On the production of fired clay bricks from waste materials: A critical update," Constr. Build. Mater., vol. 68, pp. 599-610, Oct. 2014.

[85] Y. Hsu, B. Lee, H. Liu, "Mixing Reservoir Sediment with Fly Ash to Make Bricks and Other Products," Int. Ash Util. Symp., no. 89, pp. 1-13, 2003.

[86] Z. Zhang, J. Qian, C. You, C. Hu, "Use of circulating fluidized bed combustion fly ash and slag in autoclaved brick," Constr. Build. Mater., vol. 35, no. 0, pp. 109-116, 2012.

[87] L. Zhang, "Production of bricks from waste materials - A review," Constr. Build. Mater., vol. 47, pp. 643-655, Oct. 2013.

[88] F. Peng, K. Liang, A. Hu, H. Shao, "Nano-crystal glass-ceramics obtained by crystallization of vitrified red mud," Chemosphere, vol. 59, pp. 899-903, May 2005 .

[89] F. Peng, K. M. Liang, A. M. Hu, "Nano-crystal glass-ceramics obtained from high alumina coal fly ash,” Fuel, vol. 84, no. 4, pp. 341-346, Mar. 2005.

[90] J. Yang, D. Zhang, J. Hou, B. He, B. Xiao, "Preparation of glass-ceramics from red mud in the aluminium industries," Ceram. Int., vol. 34, no. 1, pp. 125-130, Jan. 2008.

[91] R. C. Da Silva, S. a. Pianaro, S. M. Tebcherani, "Preparation and characterization of glazes from combinations of different industrial wastes," Ceram. Int., vol. 38, no. 4, pp. 2725-2731, 2012. 
[92] V. S. Nandi, F. Raupp-Pereira, O. R. K. Montedo, A. P. N. Oliveira, "The use of ceramic sludge and recycled glass to obtain engobes for manufacturing ceramic tiles," J. Clean. Prod., vol. 86, pp. 461-470, Jan. 2015.

[93] N. Yalçin, V. Sevinç, "Utilization of bauxite waste in ceramic glazes," Ceram. Int., vol. 26, no. 5, pp. 485-493, 2000.

[94] C. Lázaro, V. Ramón Trilles, F. Gómez, "Incorporación de residuos derivados de la fabricación cerámica y del vidrio reciclado en el proceso cerámico integral," Boletín la Soc. Española Cerámica y Vidr., vol. 51, no. 2, pp. 139-144, May 2012.

[95] J. García-Ten, M. F. Quereda, M. J. Vicente, C. Gil, C. Miralles, J. R. Flors, A. Peña, "Obtención de baldosas cerámicas mediante la utilización de sistemas de granulación sostenibles," Qualicer, no. 1, pp. 1-5, 2014.

[96] R. Mondragon, J. C. Jarque, J. E. Julia, L. Hernandez, A. Barba, "Effect of slurry properties and operational conditions on the structure and properties of porcelain tile granules dried in an acoustic levitator," J. Eur. Ceram. Soc., vol. 32, no. 1, pp. 59-70, Jan. 2012.

[97] C. Lázaro, V. Ramón Triles, F. Gómez, "Incorporación de residuos derivados de la fabricación cerámica y del vidrio reciclado en el proceso cerámico integral," Boletín la Soc. Española Cerámica y Vidr., vol. 51, no. 2, pp. 139-144, 2012.

[98] D. Fraga, A. Gyozova, S. Kozhukharov, S. Allepuz, C. Làzaro, V. Trilles, J. B. Carda, "Development of New Ecological Ceramic Tiles by Recycling of Waste Glass and Ceramic Materials," НАУЧНИ ТРУДОВЕ ..., pp. 8-12, 2011.

[99] M. Ahmaruzzaman, "A review on the utilization of fly ash," Prog. Energy Combust. Sci., vol. 36, no. 3, pp. 327-363, Jun. 2010.

[100] E. Menéndez, a. M. Álvaro, C. Argiz, J. L. Parra, a. Moragues, "Characterization of bottom ashes from coal pulverized power plants to determine their potential use feasibility," Boletín la Soc. Española Cerámica y 
Vidr., vol. 52, no. 6, pp. 296-304, Jan. 2014.

[101] G. Cultrone E. Sebastián, "Fly ash addition in clayey materials to improve the quality of solid bricks," Constr. Build. Mater., vol. 23, no. 2, pp. 1178-1184, 2009.

[102] I. Oueralt, X. Ouerol, A. Lpez-soler, F. Plana, "Use of coal fly ash for ceramics : a case study for a large Spanish power station," Fuel, vol. 76, no. 8, pp. 787-791, 1997.

[103] a. Acosta, M. Aineto, I. Iglesias, M. Romero, J.Ma. Rincón, "Physico-chemical characterization of slag waste coming from GICC thermal power plant," Mater. Lett., vol. 50, no. 4, pp. 246-250, 2001.

[104] a. Acosta, I. Iglesias, M. Aineto, M. Romero, J.Ma. Rincón, "Utilisation of IGCC slag and clay steriles in soft mud bricks (by pressing) for use in building bricks manufacturing," Waste Manag., vol. 22, no. 8, pp. 887-891, Dec. 2002.

[105] M. Aineto, A. Acosta, I. Iglesias, "The role of a coal gasification fly ash as clay additive in building ceramic," J. Eur. Ceram. Soc., vol. 26, no. 16, pp. 37833787, Jan. 2006.

[106] M. Aineto, A. Acosta, J.Ma. Rincón, "Production of Lightweight Aggregates from Coal Gasification Fly Ash and Slag,” 2005.

[107] E. Sánchez, J. García-Ten, V. Sanz, a. Moreno, "Porcelain tile: Almost 30 years of steady scientific-technological evolution," Ceram. Int., vol. 36, no. 3, pp. 831845, Apr. 2010.

[108] M. T. Tichell, J. Bakali, A. Pascual, I. N. Y. J. B. Carda, "Special enamels for porcelained stoneware substrates," Cerámica y Vidr., vol. 39, no. 1, pp. 31-38, 2000 .

[109] J.Ma. Rincón, J. Carda, J. Alarcón, Nuevos productos y tecnologías de esmaltes 
y pigmentos cerámicos. 1992.

[110] B. E. Yekta, P. Alizadeh, L. Rezazadeh, "Floor tile glass-ceramic glaze for improvement of glaze surface properties," J. Eur. Ceram. Soc., vol. 26, no. 16, pp. 3809-3812, Jan. 2006.

[111] norma española, "UNE-EN ISO 10545-13. Determinación de la resistencia química.," vol. 00, no. 91. 1998.

[112] I. Standard, "International Standard ISO 22196 Plastics - Measurement of antibacterial activity on plastics surfaces," vol. 2007. 2007.

[113] T. G. Sahama, “The Secondary Tungsten Minerals, a Review,” Mineral. Rec., vol. 5, no. March-April, pp. 81-87.

[114] I. E. Grey, W. D. Birch, C. Bougerol, S. J. Mills, "Unit-cell intergrowth of pyrochlore and hexagonal tungsten bronze structures in secondary tungsten minerals," J. Solid State Chem., vol. 179, no. 12, pp. 3860-3869, 2006.

[115] G. Rosales, J. B. Carda Castelló, P. Thierry, J. P. Cosp, and J. Lira-Olivares, "Desarrollo de esmaltes y fritas vitrocerámicas ricas en óxido de hierro para aplicación en pavimentos porcelánicos.," Qualicer, pp. 1-13, 2010.

[116] L. A. Espinosa Villegas, "Estudio de la cristalización de vidrios tipo piroxeno obtenidos a partir de residuos industriales," 2011.

[117] L. Barbieri, I. Queralt, J.Ma. Rincón, M. Romero-Pérez, "Vitrification of fly ash from thermal power stations," Glas. Technol., vol. 38, no. 5, pp. 165-170, 1997. 